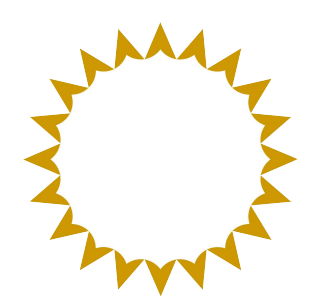

\title{
FAUUSP
}

\author{
UNIVERSIDADE DE SÃO PAULO \\ FACULDADE DE ARQUITETURA E URBANISMO
}

RUY BARBOSA SOARES FILHO

RESPOSTA HUMANA À LUZ: ALTERAÇÕES NÃO VISUAIS E O PROJETO LUMINOTÉCNICO RESIDENCIAL COM LEDs

São Paulo 
Folha de Aprovação

Ruy Barbosa Soares Filho

\section{Resposta humana à luz: alterações não visuais e o projeto luminotécnico residencial com LEDs}

Dissertação apresentada à Faculdade de Arquitetura e Urbanismo da Universidade de São Paulo para obtenção do Título de Mestre

Trabalho aprovado. São Paulo, 15 de maio de 2018:

Prof. Dr. Leonardo Marques Monteiro

Orientador

Professor Dr. Isac Roizemblat

Convidado 1

Professora Dra. Cláudia V. Torres

Barbosa

Convidado 2

São Paulo

2018 
Ruy Barbosa Soares Filho

\title{
Resposta humana à luz: alterações não visuais e o projeto luminotécnico residencial com LEDs
}

\author{
Dissertação apresentada à Faculdade de Ar- \\ quitetura e Urbanismo da Universidade de \\ São Paulo para obtenção do Título de Mestre
}

\author{
Universidade de São Paulo \\ Faculdade de Arquitetura e Urbanismo \\ Programa de Pós-Graduação
}

Orientador: Prof. Dr. Leonardo Marques Monteiro

São Paulo

2018 
AUTORIZO A REPRODUÇÃO E DIVULGAÇÃO TOTAL OU PARCIAL DESTE TRABALHO POR QUALQUER MEIO CONVENCIONAL OU ELETRÔNICO PARA FINS DE ESTUDO E PESQUISAS, DESDE QUE CITADA A FONTE.

\section{EXEMPLAR REVISADO E ALTERADO EM RELAÇÃO À VERSÃO ORIGINAL, SOB RESPONSABILIDADE DO AUTOR E ANUENCIA DO ORIENTADOR.}

A versão original, em formato digital, ficará arquivada na Biblioteca da Faculdade. São Paulo, 12 de junho de 2018.

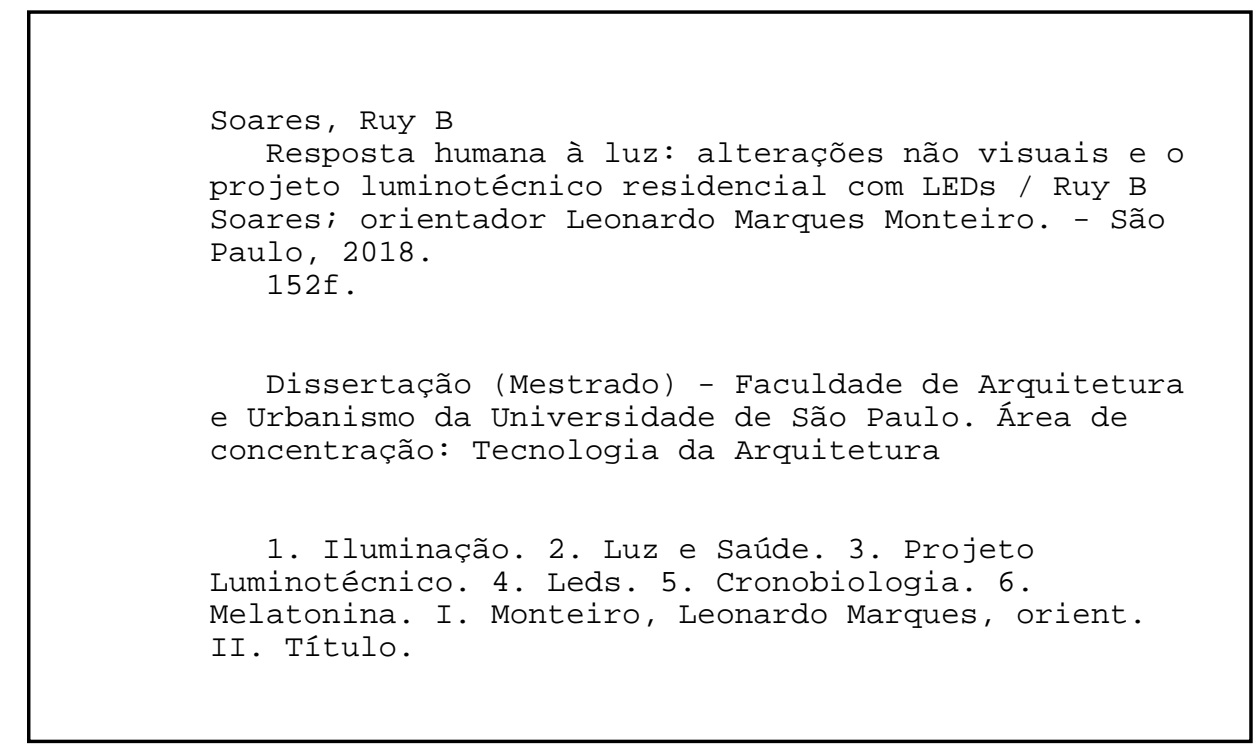

Elaborada eletronicamente através do formulário disponível em: 〈http://www.fau.usp.br/fichacatalografica/> 
Dedico esta pesquisa a meus pais,

especialmente pelo exemplo que sempre me deram,

pelo trabalho que desempenharam no campo da Educação

e pela dedicação na formação do meu caráter. 


\section{Agradecimentos}

Meus agradecimentos principais são direcionados às pessoas que deram suporte permanente a este trabalho e a mim, enquanto enfrentava este desafio: Jayme Liande, por ter suportado minhas ausências e se sobrecarregado para que eu pudesse me dedicar à pesquisa; e Silvia Bigoni, pela disponibilidade a qualquer momento do dia ou da noite.

Agradecimentos especiais são direcionados aos meus professores Isac Roizenblatt e Nelson Solano Vianna, cujos exemplos me influenciaram a iniciar esta jornada acadêmica;

ao meu caríssimo professor Leonardo Monteiro, que aceitou a tarefa de orientar um aluno interdisciplinar a materializar um trabalho interdisciplinar, tornando cada encontro extremamente produtivo;

aos professores José Cipolla Neto, que disponibilizou o Laboratório de Fisiologia do ICB para as dosagens de 6-sulfatoximelatonina, fornecendo todo o material necessário, além de orientar a criação do protocolo utilizado para este estudo; Luiz Menna-Barreto, por ter disponibilizado os actímetros e pelos banquinhos semanais, que me auxiliaram ao longo do estudo de caso; e Elvo Calixto Burini Jr., pelos testes no laboratório do IEE;

às amigas Rose Raad e Sandra Sayuri, a primeira por ter aberto caminho para a análise e seleção dos óculos bloqueadores de luz azul e a segunda pela disponibilidade e auxílio durante a análise estatística;

à empresa Itaim Iluminação, pelo empréstimo do luminancímetro utilizado neste trabalho;

ao Grupo Multidisciplinar de Desenvolvimento e Ritmos Biológicos da EACH, que me acolheu nos encontros semanais, trouxe informações valiosas para esta pesquisa e novos amigos para a vida. 
"Grandes conquistas necessitam dois elementos: um plano, e tempo quase insuficiente". 


\section{Resumo}

Esta pesquisa traz à tona, de forma interdisciplinar, estudos realizados e em andamento nas áreas de medicina, fisiologia, biologia, saúde pública, psicologia, engenharia e arquitetura, para investigar algumas alterações fisiológicas provocadas pela luz produzida pelos LEDs e, a partir da análise dos dados coletados, estabelecer em caráter preliminar novos parâmetros a serem considerados e aplicados ao projeto luminotécnico residencial que utiliza LEDs como fonte de luz. Desenvolvemos um protocolo para coletar os dados e comparar, para cada sujeito, o comportamento das variáveis entre dois períodos distintos, com a duração de 3 dias cada: um período em que, à noite, os sujeitos utilizaram óculos bloqueadores de luz azul (Período $B B$ ) e outro em que, também à noite, permaneceram expostos à iluminação artificial de LEDs em seus ambientes de maior permanência, previamente por eles definidos (Período LED). Verificamos a carga excretada de 6-sulfatoximelatonina na urina noturna de 12 horas $(n=10)$, as variações de temperatura corporal $(n=9)$ e as variáveis produzidas por meio da actimetria $(\mathrm{n}=10)$. Confrontamos estes dados com a literatura atual e com as características dos respectivos sistemas de iluminação. Do grupo de 10 sujeitos, 7 apresentaram redução da carga excretada de 6-sulfatoximelatonina do Período $B B$ para o Período LED. A análise de temperatura corporal do grupo de 9 sujeitos, revelou que 7 deles apresentaram atraso de fase do respectivo ritmo do Período BB para o Período $L E D$. A actimetria não revelou diferenças significativas entre os períodos. Porém, para o grupo que apresentou redução da carga excretada de 6-sulfatoximelatonina do Período BB para o Período LED, o L5 (período de 5 horas de menor atividade motora) apresentou um atraso de fase médio de 15 minutos. Os resultados desta pesquisa comprovam, pela primeira vez por meio de um estudo de campo, que os LEDs utilizados nos sistemas de iluminação artificial do ambiente residencial, possuem a capacidade de causar impactos deletérios na saúde dos usuários.

Palavras-chave: Luz e saúde. Projeto luminotécnico. LEDs. Cronobiologia. Melatonina. 


\section{Abstract}

This research uses interdisciplinary ongoing studies in medicine, physiology, biology, public health, psychology, engineering and architecture, to investigate some physiological changes caused by the light emitted by LEDs and, based on the results, establish in a preliminary way, new parameters to be considered and applied to residential lighting projects using LEDs as a light source. We developed a protocol to collect some data and we compared, for each subject, the values between two distinct periods of 3 days each: the $B B$ Period, where subjects wore blue-light blocking glasses at night, and the LED Period, where they were exposed to their room's LED lights at night. We verified the excreted load of 6-sulfatoxymelatonin in the 12-hour overnight urine $(n=10)$, changes in pheripheral body temperature $(n=9)$, and the variables of actimetry $(n=10)$. We analyzed these data using information provided by the current literature and crossed these data with the characteristics of the lighting systems. Within the group of 10 subjects, 7 had a reduction in the excreted load of 6-sulfatoxymelatonin from the BB Period to the LED Period. The analysis of body temperature from the group of 9 subjects revealed that 7 of them showed acrophase phase delay from the BB Period to the LED Period. Actimetry did not reveal significant differences between these periods. However, for the group which showed a reduction in the excreted load of 6-sulfatoxymelatonin from the $B B$ Period to the $L E D$ Period, the L5 (least active 5-hour period) presented, in average, a 15-minute phase delay. The results of this research prove, for the first time through a field study, that the LEDs used in residential lighting systems fave the capacity to cause deleterious impacts on users' health.

Keywords: Light and Health. Lighting Design. LEDs. Chronobiology. Melatonin. 


\section{Lista de ilustrações}

Figura 1 - Olho humano. Fonte: modificado de $<$ www.webvision.med.utah.edu/ book/part-i-foundations/introduction $>\ldots$. . . . . . . . . . . 21

Figura 2 - Diagrama simplificado do trato ótico primário. Fonte: Adaptado de $($ IESNA, 2008) f . . . . . . . . . . . . . . . 21

Figura 3 - Curva de sensibilidade espectral dos bastonetes, estabelecida pelo CIE 1988. Fonte: (BOYCE, 2014, p. 48) . . . . . . . . . . . . 22

Figura 4 - Curva de sensibilidade espectral dos cones, estabelecida por Kaiser, P.K. e Boynton, R.M em Human Color Vision, 1996. Fonte: (BOYCE, 2014,

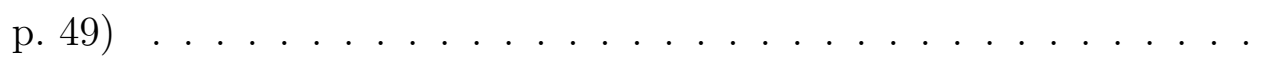

Figura 5 - Curvas de eficiência luminosa, estabelecidas pelo CIE. Fonte: modificado de $<$ www.webvision.med.utah.edu/imageswv/Kall5.jpeg $>$. . . . . . 24

Figura 6 - O recém descoberto fotorreceptor, composto por células ganglionares intrinsecamente fotossensíveis. A transdução de luz em sinais elétricos parece ter lugar por todo o corpo celular (estrutura circular escura), bem como pelas suas ramificações. Fonte: Traduzido de Brown University News Service. Disponível em <www.brown.edu/Administration/News

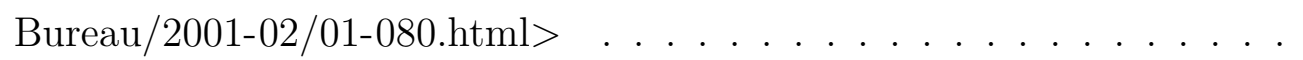

Figura 7 - Diagrama simplificado da neuroanatomia responsável pela mediação da capacidade sensorial do sistema visual, da regulação circadiana não-visual, das funções neuroendócrinas e das funções neurocomportamentais. Fonte: (MARTAU, 2009).

Figura 8 - Curva de sensibilidade espectral do fotopigmento melanopsina. O pico de sensibilidade espectral ocorre em torno de 480nm, com 90nm de largura de banda à meia altura (FWHM - Full Width at Half Maximum). Fonte: modificado de (REA; FIGUEIRO, 2016) . . . . . . . . . . . . . 28

Figura 9 - Fisiologia da Secreção de Melatonina. A melatonina é produzida na glândula pineal. Sua produção e secreção são mediadas principalmente por fibras nervosas pós-ganglionares que passam através do trato retinohipotalâmico aos núcleos supraquiasmáticos em seguida para o gânglio cervical superior e, finalmente, a glândula pineal. Este sistema neural é ativado pela ausência e reprimido pela incidência de luz na retina. Fonte: Adaptado de (SHIRANI; LOUIS, 2009) . . . . . . . . . . . . . . 31 
Figura 10 - Ao alimentar a junção PN do LED, os elétrons se movem da área N para a área $\mathrm{P}$ e lacunas da área $\mathrm{P}$ se movem em direção à área N. Perto da junção, os elétrons e as lacunas se combinam, liberando energia sob a forma de luz. Fonte: adaptado de <www.lrc.rpi.edu/programs/nlpip/ lightinganswers/led/whatisanled.asp $>\ldots$. . . . . . . . . 37

Figura 11 - Curva spectral de um LED de luz branca. Há um pico de emissão de luz azul em torno de $460 \mathrm{~nm}$ (eletroluminescência) e uma emissão secundária mais larga na região de comprimentos de onda mais longos do espectro (fosforescência). Fonte: adaptado de (SPIVEY, 2011) . . . 39

Figura 12 - Comparação entre a composição espectral de três diferentes fontes de luz (linha azul) e sua capacidade de estimular a fotorrecepção circadiana (linha vermelha). Fonte: gráficos gerados no "toolbox"mencionado em (LUCAS et al., 2014) . . . . . . . . . . . . . . . . . . . . 4 41

Figura 13 - Calculadora CS, que visa dar suporte aos profissionais de iluminação na seleção de fontes de luz artificial e níveis de iluminância para espaços arquitetônicos adequados ao sistema não visual. Fonte: Página WEB do Lighting Research Center do Instituto Politécnico Rensselaer. . . . . 42

Figura 14 - Toolbox disponibilizado a partir do First International Workshop on Circadian and Neurophysiological Photometry. Fonte: (CIE-TN-003:2015,

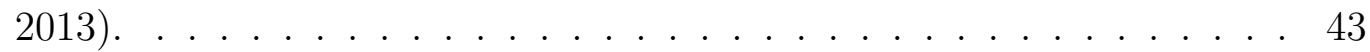

Figura 15 - Metabolização da Melatonina. Fonte: (BORGES, 2006). . . . . . . . . . 48 Figura 16 - Curva com as oscilações do ritmo de temperatura corporal e suas características. Fonte: Adaptado de (CORNELISSEN, 2014) . . . . . . . 48

Figura 17 - Maxim iButton Thermochron modelo DS1921H5. Fonte: <www.maximintegrated. com/en/products/digital/data-loggers/DS1921Z.html > . . . . . . . . 49

Figura 18 - Tela do software ActStudio mostrando o Actograma de um dos sujeitos do estudo de caso. . . . . . . . . . . . . . . . . . . . . 50

Figura 19 - Actímetro ActTrust da Condor Instruments. Fonte: <www.condorinst.

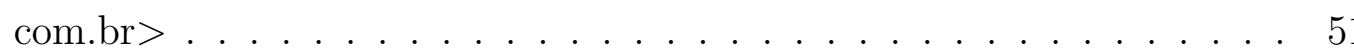

Figura 20 - Óculos testados no Laboratório de Fotometria do IEE-USP. Fotografia: Rose Raad . . . . . . . . . . . . . . . . . . . . . . . . . . 52

Figura 21 - Espectrorradiômetro (detalhe). Na foto vemos à direita a fonte de luz para os testes e no centro a caixa que contém, no fundo, a fotocélula. Os óculos foram posicionados dentro desta caixa, o mais próximo possível da fotocélula. Fotografia: o autor . . . . . . . . . . . . . . 53

Figura 22 - Distribuição espectral dos LEDs utilizados nos testes dos óculos bloqueadores de luz azul. Fonte: Relatório emitido pelo IEE-USP . . . . . . . 53 
Figura 23 - Distribuição espectral resultante da luz dos LED utilizados nos testes, filtrada pela lente dos óculos bloqueadores de luz azul. Fonte: Adaptado do Relatório emitido pelo IEE-USP . . . . . . . . . . . . . . . . . 54

Figura 24 - Coletor de dados HOBO e respectivo acoplador para a programação e comunicação de dados. Fonte: Adaptado de <www.onsetcomp.com/ products/data-loggers/ua-002-64> . . . . . . . . . . . . . 55

Figura 25 - Luxímetro digital utilizado para o levantamento fotométrico dos ambientes residenciais de maior permanência à noite. Fonte: Adaptado de <www.icel-manaus.com.br $>$. . . . . . . . . . . . . . . 56

Figura 26 - Tela do aplicativo Aftab Luminance, com foto do luminancímetro utilizado na sua aferição (detalhe). Fontes: < http://aftabsoft.net/> e $<$ www.topcon-techno.co.jp/en/> . . . . . . . . . . . . . 57

Figura 27 - Filtro passa-faixa: azul. Fonte: $<$ www.edmundoptics.com $>$. . . . . . . 58

Figura 28 - Curva de transmitância do filtro passa-faixa. Fonte: $<$ www.edmundoptics.

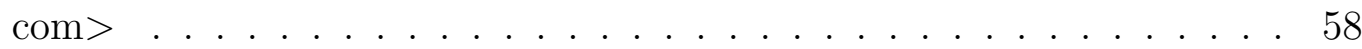

Figura 29 - Ilustração de um $i$-Button, revelando seus componentes internos. Fonte: Adaptado de $<$ www.maximintegrated.com/en/products/ibutton/ibuttons/ thermochron.cfm $>\ldots \ldots \ldots \ldots$. . . . . . . . . . . 61

Figura 30 - A e B: Instalação do i-Button; C: i-Button e Actímetro. Fonte: Fotos do autor. . . . . . . . . . . . . . . . . . 61

Figura 31 - Instalação do HOBO. Fonte: Foto do autor. . . . . . . . . . . . . . . . 62

Figura 32 - Impacto da luz noturna de LEDs sobre a síntese de melatonina. Os blocos com preenchimento sólido se referem aos 7 sujeitos que apresentaram redução hormonal entre o Período $B B$ e o Período LED. Os blocos listrados se referem aos 3 sujeitos em que esta relação não foi observada. 66

Figura 33 - Exemplo da representação temporal dos dados de dois dias da temperatura corporal, extraída do software ActStudio, com os cálculos de MESOR, Amplitude e Acrofase para o período de 2 dias. . . . . . . . . 68

Figura 34 - Exemplo do Diagrama Polar da análise de Cosinor. Para este sujeito, a Acrofase média ocorreu às $03 \mathrm{~h} 23 \mathrm{~m}$ no Período Antes, às $02 \mathrm{~h} 03 \mathrm{~m}$ no Período BB e às $04 \mathrm{~h} 54 \mathrm{~m}$ no Período LED . . . . . . . . . . . . . . . . 68

Figura 35 - Impacto da luz noturna de LEDs sobre o ritmo de temperatura corporal. No Período Antes a Acrofase média ocorreu às 03h08m, no Período BB às $01 \mathrm{~h} 58 \mathrm{~m}$ e no Período $L E D$ às $03 \mathrm{~h} 55 \mathrm{~m} . \quad$. . . . . . . . . . . . . . . . 69 


\section{Lista de tabelas}

Tabela 1 - Classificação de Cronotipo, segundo Horne e Östberg . . . . . . . . . . 46

Tabela 2 - Pontuação do Pittsburg Sleep Quality Index . . . . . . . . . . . . . . 46

Tabela 3 - Pontuação da escala de sonolência de Epworth . . . . . . . . . . . . . 46

Tabela 4 - Levantamento fotométrico dos ambientes residenciais envolvidos neste estudo (Iluminâncias e caraterísticas dos sistemas). . . . . . . . . . 63

Tabela 5 - Levantamento fotométrico dos ambientes residenciais envolvidos neste estudo (Luminâncias). . . . . . . . . . . . . . . . . . . . . . . 63

Tabela 6 - Significâncias estatísticas entre os pares de dados, calculadas pelo teste de Wilcoxon Pareado para o grupo em que houve resposta hormonal à luz noturna. . . . . . . . . . . . . . . . . 67 


\section{Lista de abreviaturas e siglas}

CIE Commission Internationale de L'Eclairage

CS Circadian Stimulus - Unidade proposta por (REA et al., 2005)

DLMO Dim Light Melatonin Onset - início da síntese de melatonina

DNA ácido desoxirribonucleico - complexo orgânico com instruções genéticas

FWHM largura de banda à meia altura

HDR High Dinamic Range

iPRGC células ganglionares intrinsecamente fotossensíveis

IRC Indice de Reprodução de Cores

LED diodo emissor de luz

LUX $\quad$ unidade de iluminância

SI Sistema Internacional de unidades

UGR Unified Glare Rating

$\mathrm{V}(\lambda) \quad$ função de eficiência luminosa fotópica

$\mathrm{V}^{\prime}(\lambda) \quad$ função de eficiência luminosa escotópica

Zeitgeber sincronizador ambiental, aquele que regula o tempo 


\section{Sumário}

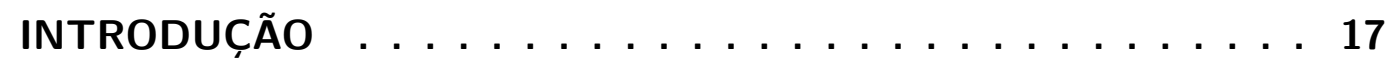

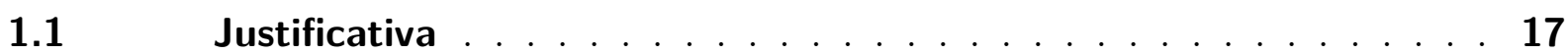

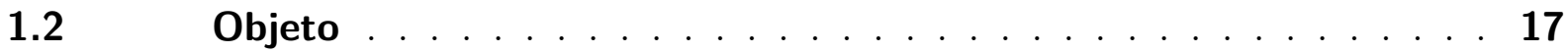

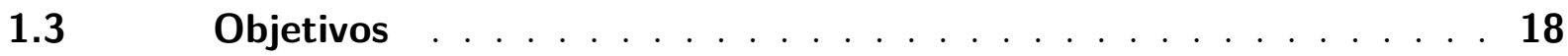

$1.4 \quad$ Estrutura da dissertação . . . . . . . . . . . . . . . 18

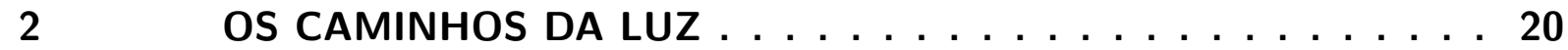

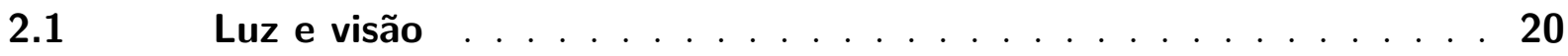

2.1.1 Ação dos fotorreceptores para o sistema visual . . . . . . . . . . . . 20

2.1.2 Sensibilidade espectral do sistema visual . . . . . . . . . . . . . . . 22

2.2 Sistema não visual $\ldots \ldots \ldots \ldots$

2.2.1 Ação dos fotorreceptores para o sistema não visual . . . . . . . . . . 26

2.2.2 Sensibilidade espectral do sistema não visual . . . . . . . . . . . . . . . 27

3 O CORPO HUMANO E O CLARO-ESCURO AMBIENTAL . . . 29

$3.1 \quad$ Melatonina: $\mathbf{O}$ principal marcador temporal fisiológico . . . . . 30

3.1.1 Propriedades e ações da melatonina . . . . . . . . . . . . . . . 32

4 ILUMINAÇÃO ARQUITETÔNICA E SAÚDE . . . . . . . . . . . 34

$4.1 \quad \mathrm{O}$ papel da arquitetura $\ldots \ldots \ldots \ldots \ldots$

$4.1 .1 \quad$ lluminação natural . . . . . . . . . . . . . . . . . . . . . . . 34

4.1 .2 Iluminação artificial . . . . . . . . . . . . . . . . . . 35

$4.2 \quad$ Fontes de luz artificial $\ldots \ldots \ldots \ldots \ldots \ldots$

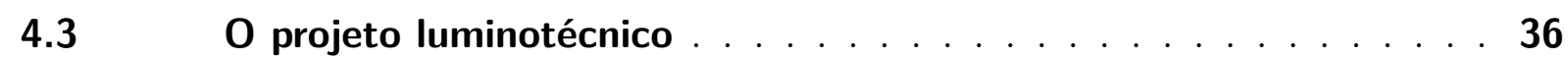

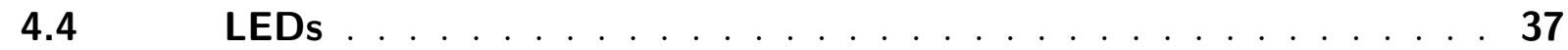

$4.4 .1 \quad$ A Revolução dos LEDs . . . . . . . . . . . . . . . . . . 38

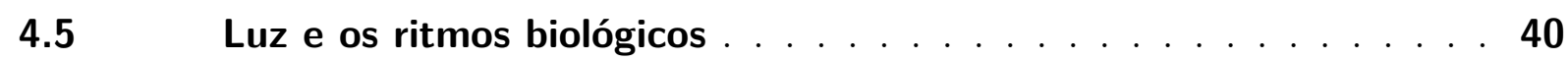

4.5.1 Quantificando a luz para a sincronização circadiana . . . . . . . . . . . 40

5 ESTUDO DE CASO ENVOLVENDO PESSOAS EXPOSTAS À ILUMINAÇÃO NOTURNA COM LEDS NO AMBIENTE RESIDENCIAL 45

$5.1 \quad$ Características do estudo . . . . . . . . . . . . . 45

5.2 Metodologia utilizada para a coleta de dados - sujeitos . . . . . . 45

5.2 .1 Questionários . . . . . . . . . . . . . . . . . . . . . 45

5.2.1.1 Questionário de cronotipo de Horne e Östberg . . . . . . . . . . . . . . . . 45

5.2.1.2 Avaliação de transtorno psiquiátrico - Self Reporting Questionnaire - SRQ-20 . . 46 
5.2.1.3 Avaliação da qualidade do sono - Pittsburg Sleep Quality Index - PSQI . . . . . 46

5.2.1.4 Escala de sonolência de Epworth . . . . . . . . . . . . . . . . . . 46

5.2.2 6-Sulfatoximelatonina . . . . . . . . . . . . . . . . . 47

5.2.3 Temperatura corporal . . . . . . . . . . . . . . . . 47

$5.2 .4 \quad$ Actimetria . . . . . . . . . . . . . . . . 50

5.2.5 Simulação de fase escura para a coleta de dados - Óculos bloqueadores de luz azul . . . . . . . . . . . . . . . . . . . . 51

$5.2 .6 \quad$ Exposição à luz . . . . . . . . . . . . . . . . . . 52

$5.3 \quad$ Metodologia utilizada para a coleta de dados - ambientes . . . . . 56

5.3.1 Características dos sistemas e iluminâncias . . . . . . . . . . . . . . . . 56

$5.3 .2 \quad$ Luminâncias . . . . . . . . . . . . . . . . . . 56

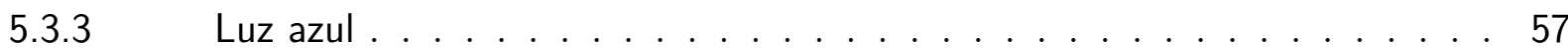

$5.4 \quad$ Preparação para o estudo de caso . . . . . . . . . . . . . . . 58

$5.4 .1 \quad$ Sujeitos . . . . . . . . . . . . . . . . . 58

$5.4 .2 \quad$ Preenchimento de formulário . . . . . . . . . . . . . . 59

$5.4 .3 \quad$ Critérios de inclusão . . . . . . . . . . . . . . . . . . . 59

5.4.4 Critérios de exclusão . . . . . . . . . . . . . . . . . . 59

5.4.5 Desenvolvimento de protocolo para o estudo de caso . . . . . . . . . . 59

5.4.6 TCLE - Termo de Consentimento Livre e Esclarecido . . . . . . . . . . . . 60

5.5 Procedimentos adotados durante a coleta de dados . . . . . . . . 60

5.5.1 Programação e instalação dos equipamentos para a coleta de dados . . . . 60

5.5.2 Coleta de urina para a dosagem de 6-sulfatoximelatonina . . . . . . . . . . 61

5.5.3 Levantamento fotométrico e coleta de imagens fotográficas . . . . . . . . . 63

5.5.4 Protocolo completo . . . . . . . . . . . . . . . . . . . . 64

5.6 Preparação dos dados para análise . . . . . . . . . . . . . . 64

$5.6 .1 \quad$ Análise estatística . . . . . . . . . . . . . . . . . 65

$5.7 \quad$ Análise dos resultados . . . . . . . . . . . . . . . . . 65

5.7.1 6-Sulfatoximelatonina . . . . . . . . . . . . 65

5.7.2 Temperatura corporal . . . . . . . . . . . . . . 67

5.7.2.1 Acrofase . . . . . . . . . . . . . . . . . . 69

5.7.2.2 Amplitude e Mesor . . . . . . . . . . . . . . . . . . . . . . 69

5.7.3 Actimetria . . . . . . . . . . . . . . . . . . . 69

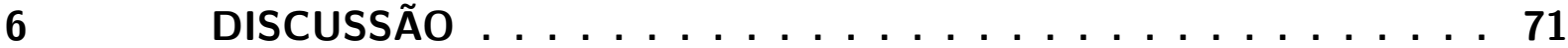

$6.1 \quad$ Limitações deste estudo . . . . . . . . . . . . . . . . . 73

6.2 Recomendações para o projeto luminotécnico residencial com LEDS 73

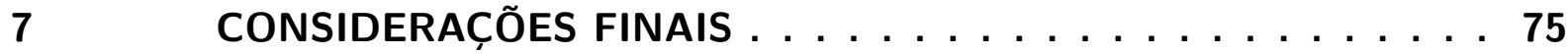

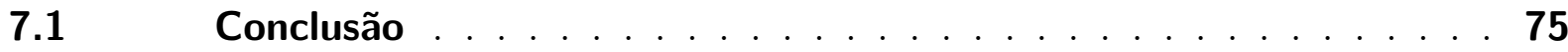

7.2 Projeção para pesquisas futuras . . . . . . . . . 76 
APÊNDICE A - INSTRUÇÕES DIÁRIAS PARA OS PROCEDIMENTOS DO ESTUDO DE CASO . . . . . . . . 84

APÊNDICE B - TCLE - TERMO DE CONSENTIMENTO LIVRE E ESCLARECIDO . . . . . . . . 86

APÊNDICE C - ANÁLISES DE COSINOR - TEMPERATURA CORPORAL . . . . . . . . . . . 87

APÊNDICE D - ANÁLISE FOTOGRÁFICA - LUMINÂNCIAS . . . 114 APÊNDICE E - ANÁLISE FOTOGRÁFICA - LUZ AZUL . . . 120 APÊNDICE F - FICHA DE DADOS CADASTRAIS . . . . 126

ANEXO A - COMITÊ DE ÉTICA EM PESQUISA ENVOLVENDO SERES HUMANOS . . . . . . . . . . . . 132

ANEXO B - QUESTIONÁRIO DE CRONOTIPO DE HORNE ÖSTBERG . . . . . . . . . . . . 137

ANEXO C - SELF REPORTING QUESTIONNAIRE - SRQ-20 _ 143 ANEXO D - PITTSBURG SLEEP QUALITY INDEX - PSQI . . 146 ANEXO E - ESCALA DE SONOLÊNCIA DE EPWORTH . . . 151 


\section{Introdução}

A relação entre luz e arquitetura foi inicialmente orientada pelo senso comum de que necessitamos extrair informações visuais do ambiente. A arquitetura cria os espaços com suas formas, cores e texturas. O lighting designer utiliza suas técnicas na busca de um resultado que tenha significado e que desperte interesse visual (BOYCE, 2014, p. 227).

Porém, há pouco mais de 15 anos (BERSON; DUNN; TAKAO, 2002), houve a descoberta de que possuímos em nosso olhos um sistema não visual, mediado por uma nova classe de fotorreceptores, que convertem luz em sinais nervosos que chegam ao cérebro para organizar a ritmicidade de marcadores temporais internos, em ciclos, que regulam a fisiologia ${ }^{1}$ dos seres de acordo com sua posição exata no planeta e promovem sua saúde. A evolução deste conhecimento consolidou a relação entre luz e saúde.

O projeto luminotécnico, antes orientado à arquitetura, começa a ter seus parâmetros revistos, sendo cada vez mais orientado ao usuário, num movimento mundial denominado Human-Centric Lighting ${ }^{2}$.

\subsection{Justificativa}

Do ponto de vista do projeto luminotécnico, a relação entre a luz e o sistema endócrino $^{3}$ é pouco considerada. Particularmente, no que se refere à luz emitida por $\mathrm{LEDs}^{4}$, as consequências impostas ao sistema endócrino e à fisiologia humana são ainda negligenciadas.

O crescimento dos sistemas de iluminação artificial com a utilização de diodos emissores de luz, os LEDs, tornou necessárias pesquisas para analisar os possíveis impactos da exposição prolongada a esta luz, pois a maior parte deles é capaz de estimular o recém descoberto sistema não visual.

\subsection{Objeto}

O objeto desta pesquisa é a relação entre os LEDs utilizados para iluminação arquitetônica residencial e os impactos não visuais ${ }^{5}$ causados nos usuários devido a comprimentos de onda curtos dentro da radiação visível.

\footnotetext{
ciência que estuda o funcionamento dos organismos

iluminação voltada ao ser humano (tradução do autor)

sistema constituído por glândulas que secretam hormônios

Light Emitting Diodes - diodos emissores de luz

5 relacionados ao sistema não visual, controlado pela incidência de luz no olho
} 


\subsection{Objetivos}

- Averiguar o potencial circadiano ${ }^{6}$ noturno dos ambientes residenciais iluminados por LEDs;

- Estabelecer recomendações - que considerem o sistema não visual - para a utilização de LEDs nos projetos luminotécnicos residenciais.

\subsection{Estrutura da dissertação}

- Capítulo 1 - INTRODUÇÃO

- Capítulo 2 - OS CAMINHO DA LUZ

Este capítulo apresenta uma revisão bibliográfica sobre fotorrecepção para o sistema visual e para o sistema não visual circadiano, suas características fisiológicas, mecanismos de ação e sensibilidade espectral.

- Capítulo 3 - O CORPO HUMANO E O CLARO-ESCURO AMBIENTAL

Apresentamos aqui o principal mecanismo de sincronização circadiana, a importância dos ritmos biológicos para a saúde humana e a melatonina como principal marcador temporal fisiológico;

- Capítulo 4 - ILUMINAÇÃO ARQUITETÔNICA E SAÚdE

Este capítulo estabelece uma relação direta entre e os projetos arquitetônicos e de iluminação artificial com a saúde dos usuários, trazendo o LED como protagonista dos sistemas de iluminação artificial da atualidade.

- Capítulo 5 - ESTUdO DE CASO ENVOLVENDO PESSOAS EXPOSTAS À ILUMINAÇÃO NOTURNA COM LEDS NO AMBIENTE RESIDENCIAL

Apresentamos neste capítulo nossa pesquisa de campo desde a sua preparação à metodologia adotada para a coleta de dados, as variáveis observadas, os equipamentos utilizados, o tratamento dos dados e a apresentação dos resultados obtidos.

- Capítulo 6 - DISCUSSÃO

A partir dos resultados do estudo de caso, este capítulo verifica se as suspeitas iniciais se confirmaram, procura estabelecer relações entre as variáveis examinadas, abordar as limitações deste estudo e indicar possíveis caminhos, além de formular

6 existência de luz emitida por LEDs, na região azul do especto visível, capaz de estimular o sistema não visual mediado pelo olho humano e de interferir nos ritmos biológicos, especialmente na síntese do hormônio melatonina 
recomendações para o projeto luminotécnico residencial que utiliza LEDs como fontes de luz.

- Capítulo 7 - CONSIDERAÇÕES FINAIS

Aqui falamos da relevância deste estudo para a arquitetura e para os Lighting Designers, sua inserção no estado da arte e projeções para pesquisas futuras. 


\section{Os caminhos da luz}

Ao incidir em nossos olhos, a luz é captada por fotorreceptores existentes na retina ${ }^{1}$, que projeta paralelamente para várias áreas do cérebro uma representação do mundo. Os neurônios que populam a retira conduzem por vinte vias diferentes (GAZZANIGA, 2004, p. 281) as informações fóticas que estimulam vários sistemas formadores de imagens (como visão monocromática, visão de cores, percepção de brilho e contraste) e não formadores de imagens (como reflexo pupilar, reflexo motor das pálpebras para a proteção de ameaças ao olho, reflexos viso posturais para proteger o corpo de objetos arremessados em sua direção (FEITOSA-SANTANA; MENNA-BARRETO, 2007) e sincronização circadiana ${ }^{2}$ ).

Analisaremos aqui os caminhos da luz para a visão, que neste trabalho denominaremos "Sistema Visual", e da Luz para a regulação circadiana, que denominaremos "Sistema não Visual", pois ambos estão intimamente relacionados às mudanças de padrão de exposição à luz impostas na atualidade pela iluminação artificial.

\subsection{Luz e visão}

Durante mais de 150 anos, a comunidade científica e acadêmica - envolvida em pesquisas sobre luz e visão - tem estudado o modo como captamos e percebemos a luz monocromática ou policromática que incide na retina até a formação de imagens pelo cérebro. O sistema visual é composto pelo olho, com vários componentes destinados à captação de imagens, e um complexo sistema que processa estas imagens e as interpreta no cérebro.

\subsubsection{Ação dos fotorreceptores para o sistema visual}

A fotorrecepção para o sistema visual ocorre por meio de duas classes de fotorreceptores presentes na retina: os cones, responsáveis pela visão diurna, e os bastonetes, responsáveis pela visão noturna.

Ao incidir na córnea, a luz percorre uma "verdadeira selva" (Figura 1) até atingir a retina, passando pela pupila, que se contrai ou se relaxa para controlar a quantidade de luz que chegará ao cristalino. Este, por sua vez, controla o foco da imagem de acordo com a distância dos objetos. A luz então passa por um material gelatinoso, o humor vítreo, e finalmente incide na retina onde é captada pelos fotorreceptores, que a converte em sinais elétricos que são enviados pelo nervo ótico para o córtex occipital do cérebro, por uma via

1 situada no fundo do globo ocular

2 processos biológicos temporais rítmicos 


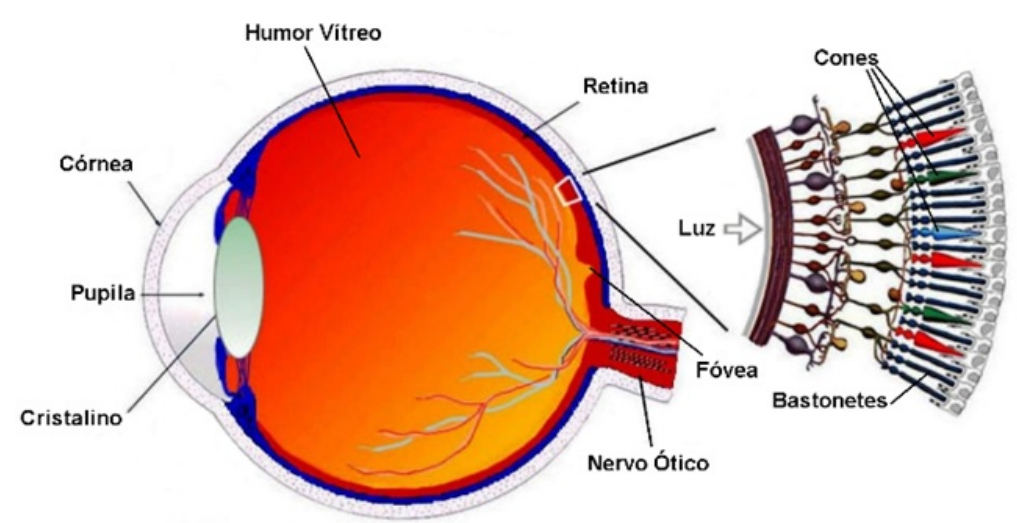

Figura 1 - Olho humano. Fonte: modificado de <www.webvision.med.utah.edu/book/ part-i-foundations/introduction>

denominada "Trato Ótico Primário" (Figura 2), que se encarrega de produzir nosso senso de visão.

A retina possui cerca de 5 milhões de cones e cerca de 110 milhões de bastonetes.

Os cones, responsáveis pela visão diurna ${ }^{3}$, são capazes de distinguir cores e se localizam com maior concentração na fóvea (área que fica no eixo visual do olho) e em seu entorno, e em muito pequena quantidade distribuída no restante da retina. Já os bastonetes, responsáveis pela visão noturna ${ }^{4}$, são incapazes de discriminar cores e não aparecem na região da fóvea, se concentrando lateralmente a 20 graus da mesma e se espalhando por toda a periferia da retina.

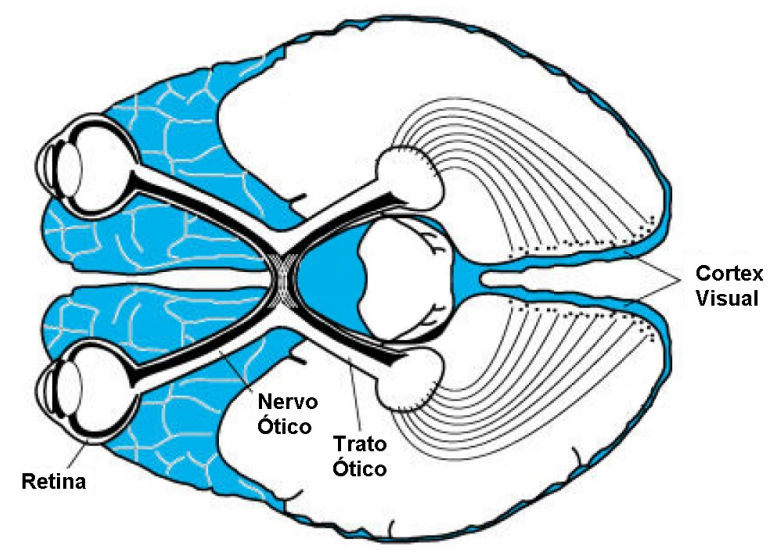

Figura 2 - Diagrama simplificado do trato ótico primário. Fonte: Adaptado de (IESNA, 2008)

\footnotetext{
3 visão fotópica

4 visão escotópica
} 


\subsubsection{Sensibilidade espectral do sistema visual}

Embora os bastonetes sejam numericamente muito mais expressivos que os cones, como vimos, estes últimos são capazes de discriminar cores além de, por se localizarem na fóvea $^{5}$, conseguirem perceber detalhes e outras características mais específicas das imagens. A capacidade de distinguir cores se dá pelo fato de haver três tipos de cones, cada um sensível a comprimentos de onda diferentes.

Temos, então, 4 tipos de fotorreceptores para o sistema visual, cada um com sua curva de sensibilidade espectral específica:

- Cones $\mathrm{S}$ - sensíveis a comprimentos de onda curtos, com pico de sensibilidade em 450nm, que corresponde à cor azul (Figura 4);

- Cones M - sensíveis a comprimentos de onda médios, com pico de sensibilidade em $525 \mathrm{~nm}$, que corresponde à cor verde (Figura 4);

- Cones L - sensíveis a comprimentos de onda longos, com pico de sensibilidade em $575 \mathrm{~nm}$, que corresponde à cor amarela (Figura 4);

- Bastonetes - sensíveis a uma ampla faixa de comprimentos de onda, com pico de sensibilidade em 504nm, sem haver distinção de cores (Figura 3).

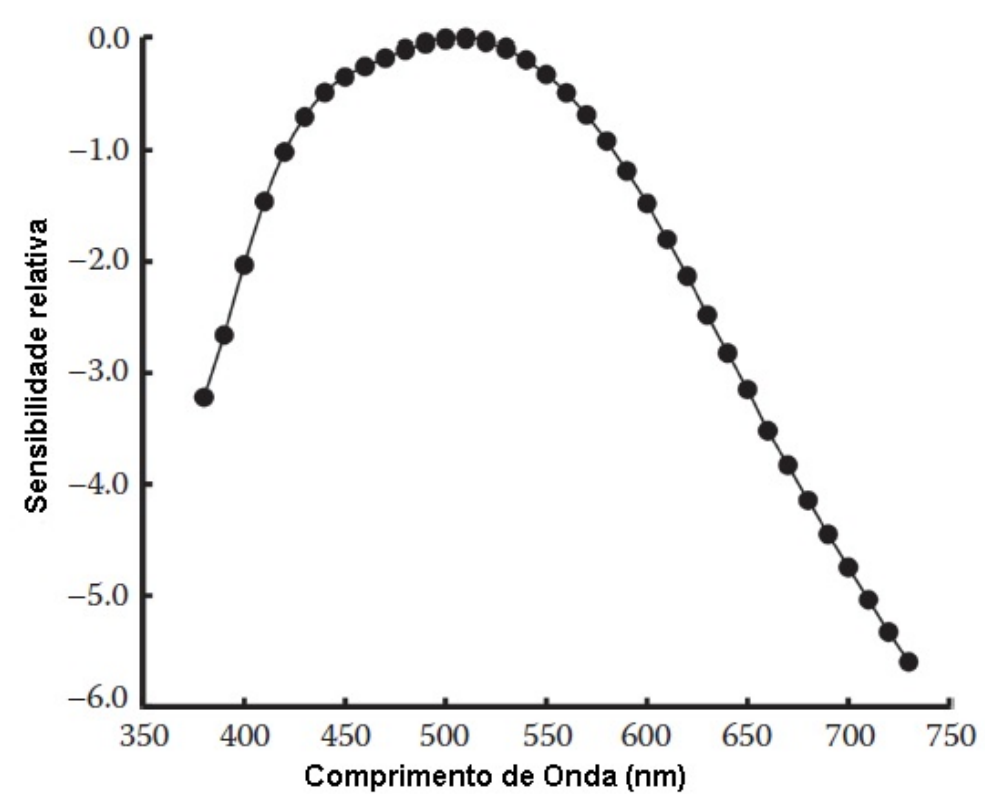

Figura 3 - Curva de sensibilidade espectral dos bastonetes, estabelecida pelo CIE 1988. Fonte: (BOYCE, 2014, p. 48)

A relação numérica entre os cones "L", "M" e "S" é de aproximadamente 32:16:1 (BOYCE, 2014, p. 50).

\footnotetext{
5 a luz que incide na fóvea não necessita atravessar axônios para chegar aos fotorreceptores
} 


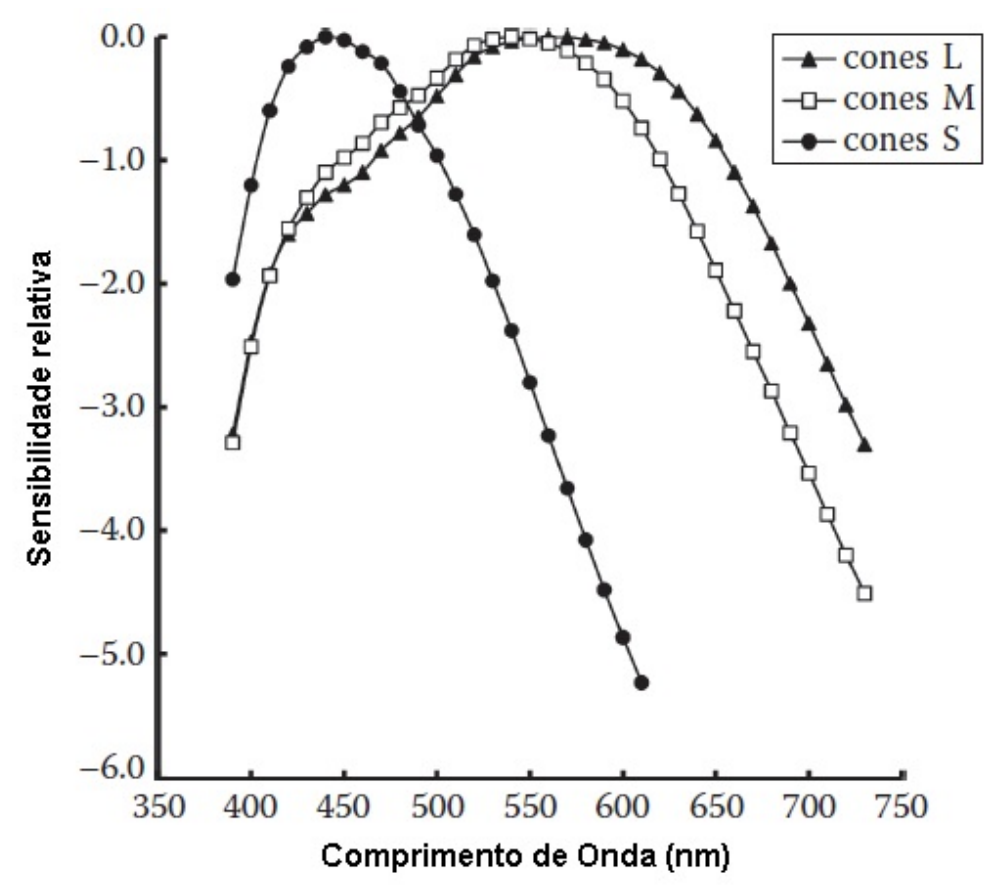

Figura 4 - Curva de sensibilidade espectral dos cones, estabelecida por Kaiser, P.K. e Boynton, R.M em Human Color Vision, 1996. Fonte: (BOYCE, 2014, p. 49)

A ação conjunta destes 4 tipos de fotorreceptores dá origem a curvas de sensibilidade espectral específicas, chamadas função de eficiência luminosa. Também estabelecidas pelo CIE, a função de eficiência luminosa fotópica (visão diurna) é conhecida como $\mathrm{V}(\lambda)$ e possui pico de sensibilidade espectral em 555nm. Do mesmo modo, a função de eficiência luminosa escotópica (visão noturna) é conhecida como $\mathrm{V}^{\prime}(\lambda)$ e possui pico de sensibilidade espectral em 507nm (Figura 5).

\subsection{Sistema não visual}

Os movimentos regulares do planeta determinam ciclos ambientais que, ao longo de sua evolução, estimularam os seres a desenvolver ritmos internos de cerca de 6 horas (movimento das marés), de 24 horas, de 365 dias, de 29,5 dias (lunação) e muitos outros, que determinam aspectos como ciclo de reprodução, migração e hibernação.

Nos seres humanos, as alterações do claro-escuro ambiental propiciaram o desenvolvimento de mecanismos que regulam suas funções biológicas em ciclos, que controlam as oscilações da temperatura corporal, secreção de hormônios, sono, estado de alerta, além de oscilações ao nível celular como mitose ${ }^{6}$ e reparo de danos ao DNA (REA; BIERMAN; FIGUEIRO, 2008).

Como cada ciclo tem a duração de aproximadamente 24 horas, recebeu a denomi- 


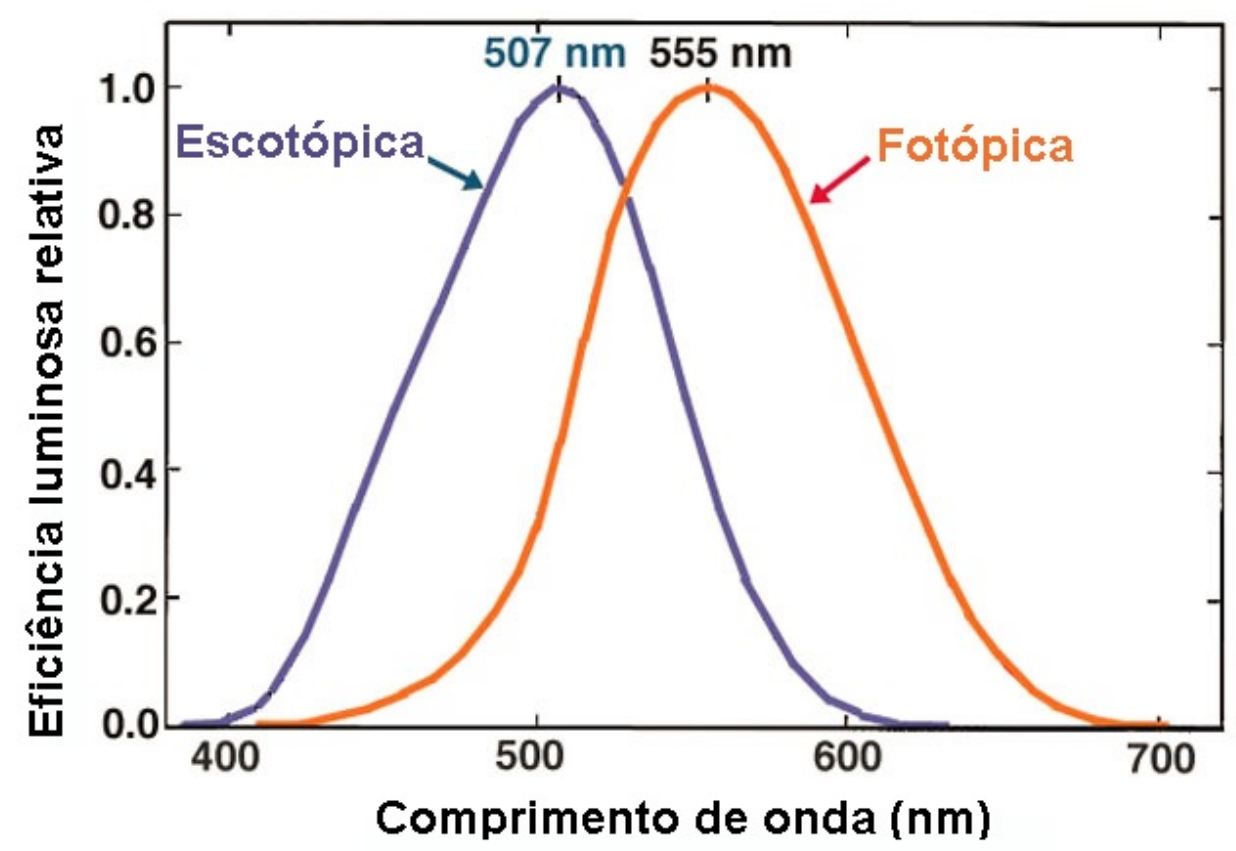

Figura 5 - Curvas de eficiência luminosa, estabelecidas pelo CIE. Fonte: modificado de $<$ www.webvision.med.utah.edu/imageswv/Kall5.jpeg $>$

nação de Ciclo Circadiano. A palavra "Circadiano" tem sua origem no latim (Circa=cerca; Diem=dia), significando "cerca de 1 dia". Na verdade, o ciclo circadiano endócrino ${ }^{7}$ tem a duração um pouco maior que um dia solar, 24,2 horas (SHIRANI; LOUIS, 2009).

O marcador biológico principal do ser humano está localizado nos núcleos supraquiasmáticos do hipotálamo cerebral e se encarrega de controlar, com precisão, vários mecanismos espalhados por todo o corpo, como a fisiologia circadiana, respostas neuroendócrinas $^{8}$ e regulação neurocomportamental. Como o regente de uma orquestra, este marcador principal organiza temporalmente todos os marcadores periféricos distribuídos pelo organismo, para que funcionem de modo harmônico e cada um a seu tempo (FOSTER; KREITZMAN, 2004, introduction). Para mantê-lo em sincronismo com o dia solar de 24 horas, os núcleos supraquiasmáticos do hipotálamo utilizam como principal fonte de informação sinais fóticos provenientes da retina ${ }^{9}$, que ocorre com a incidência de luz diretamente no olho humano.

Sabe-se há décadas que os cones e bastonetes não são os principais fotorreceptores responsáveis pela transdução ${ }^{10}$ de luz em estímulos para regular o ciclo circadiano (BRAINARD et al., 2001), tendo o modo pelo qual ocorre este sincronismo ficado por muito tempo desconhecido, até que no início da década de 1990 um grupo de neurocientistas

\footnotetext{
7 referente à produção de hormônios

8 referentes ao sistema nervoso e ao sistema hormonal

9 camada interna do globo ocular, onde se localizam os fotorreceptores

10 conversão de um estímulo ou tipo de sinal em outro
} 
propôs a possibilidade de haver no olho uma nova classe de fotorreceptores para controlar nossa fisiologia, pois uma série de estudos verificou que roedores funcionalmente cegos, eram capazes de sincronização fisiológica à luz (FOSTER et al., 1991).

Em uma publicação inédita no ano de 2002, pesquisadores mostraram que células ganglionares presentes na retina, por meio de um fotopigmento chamado melanopsina, se encarregavam de converter radiação eletromagnética visível em sinais nervosos que chegam aos núcleos supraquiasmáticos do hipotálamo cerebral (BERSON; DUNN; TAKAO, 2002). Estavam descobertas as Células Ganglionares Intrinsecamente Fotossensíveis, ou ipRGCs.

Estudos subsequentes comprovaram que este novo fotorreceptor (Figura 6) é o principal responsável pelo sincronismo dos ritmos biológicos ao dia solar, visto que pessoas funcionalmente cegas, em que os cones e os bastonetes eram inativos, ainda eram capazes de responder fisiologicamente à presença de luz (SHIRANI; LOUIS, 2009).

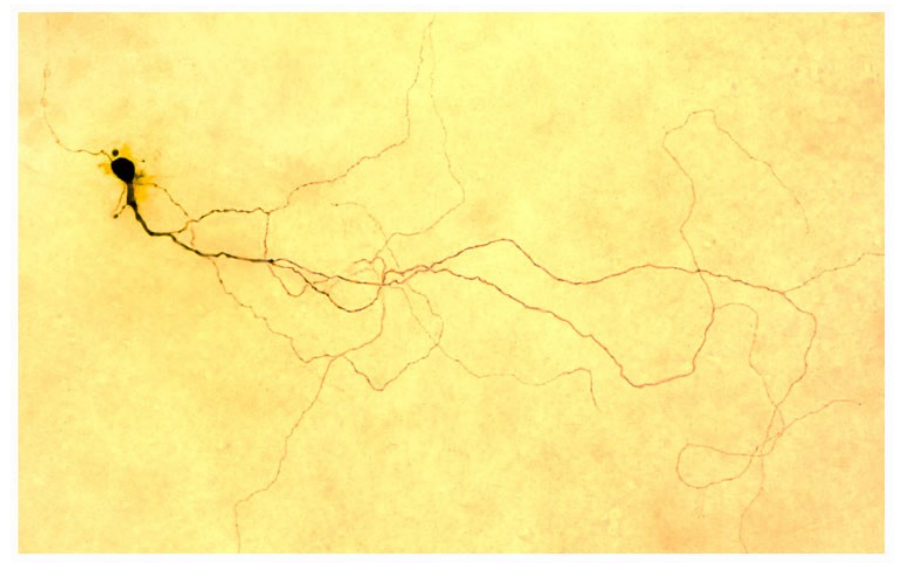

Figura 6 - O recém descoberto fotorreceptor, composto por células ganglionares intrinsecamente fotossensíveis. A transdução de luz em sinais elétricos parece ter lugar por todo o corpo celular (estrutura circular escura), bem como pelas suas ramificações. Fonte: Traduzido de Brown University News Service. Disponível em < www.brown.edu/Administration/News_Bureau/2001-02/01-080.html >

A descoberta das "Células Ganglionares Intrinsecamente Fotossensíveis", ou ipRGCs"11, consolidou a ideia de que a relação da luz com os seres humanos vai além de simplesmente propiciar auxílio à visão, dando origem a uma profusão de novos estudos, demonstrando que a luz é um potente estímulo para a regulação circadiana, neuroendócrina e neurocomportamental (ANDERSEN; GOCHENOUR; LOCKEY, 2013), pois é o principal sinalizador para a organização temporal de várias funções do organismo como sono, consumo de alimentos, regulação da temperatura corporal, regulação da frequência cardíaca, liberação de hormônios (TOSINI et al., 2008) e regulação da pressão arterial (FABBIAN et al., 2013).

11 intrinsically photosensitive retinal ganglion cells 
A falta desta organização temporal está relacionada a distúrbios do sono, déficit de atenção, alterações de humor, depressão sazonal, câncer, obesidade, diabetes e problemas cardíacos, além de prejudicar o rendimento no desempenho de tarefas e no aprendizado (TOSINI; FERGUSON; TSUBOTA, 2016).

\subsubsection{Ação dos fotorreceptores para o sistema não visual}

O olho é um órgão que permite a percepção espacial. Capta as imagens e o sistema visual dá sentido a tudo que vemos.

Esta complexa rede neural, controlada pela luz que incide nas ipRGCs da retina, confere ao olho a existência de um sistema não formador de imagens: o sistema não visual.

Pelo sistema não visual a luz, entre outros efeitos, suprime a produção pineal de melatonina, aumenta a frequência cardíaca e a temperatura corporal, estimula a produção de cortisol e atua como um estimulante neurofisiológico, aumentando as medidas subjetivas e objetivas de alerta, tempo de reação psicomotora e reduzindo os lapsos de atenção.

A partir da descoberta do sistema não visual circadiano, o olho passou a ser também entendido como um órgão da percepção temporal, pois as respostas não visuais são separadas dos aspectos da visão, na medida em que não estão relacionadas a padrões espaciais de exposição à luz.

A fim de assegurar o alinhamento correto da fisiologia com a temporização ambiental, o marcador temporal circadiano é sincronizado diariamente com o ciclo claro-escuro de 24 horas. Esta informação de luz é detectada exclusivamente pelo olho, principalmente através das recém descobertas células ganglionares retinianas que contém o fotopigmento melanopsina, anatomicamente e funcionalmente separadas dos cones e bastonetes necessários para a visão.

A luz incide nas células ganglionares intrinsecamente fotossensíveis da retina, onde há sua transdução em sinais elétricos que são conduzidos aos núcleos supraquiasmáticos do hipotálamo, que por sua vez são responsáveis pela organização temporal do organismo (TOSINI et al., 2008). Esta via neural é denominada trato retino-hipotalâmico.

Uma importante via neural se projeta dos núcleos supraquiasmáticos do hipotálamo até o gânglio cervical superior da coluna vertebral e transporta a informação não visual até a glândula pineal ${ }^{12}$, que circadianamente produz o hormônio melatonina (IESNA, 2008), responsável pelo controle da nossa fisiologia noturna.

A Figura 7 ilustra a neuroanatomia do sistema visual e do sistema não visual, abordados nos itens 2.1 e 2.2 deste trabalho.

12 pequena glândula endócrina, também conhecida como epífise, localizada no epitálamo, próximo ao centro do cérebro 


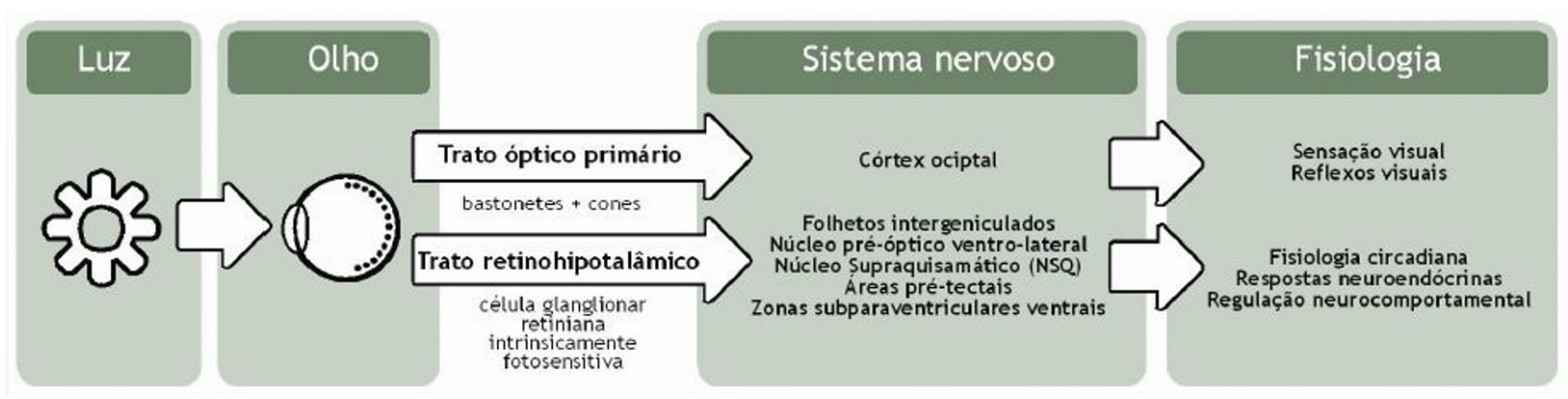

Figura 7 - Diagrama simplificado da neuroanatomia responsável pela mediação da capacidade sensorial do sistema visual, da regulação circadiana não-visual, das funções neuroendócrinas e das funções neurocomportamentais. Fonte: (MARTAU, 2009).

\subsubsection{Sensibilidade espectral do sistema não visual}

As ipRGCs são mais sensíveis à luz de comprimentos de onda curtos na região azul do espectro (LOCKEY, 2009), com curva de sensibilidade espectral apresentando pico em 480nm (LUCAS et al., 2014) e largura de banda à meia altura (FWHM - Full Width at Half Maximum) de cerca de $90 \mathrm{~nm}$ (Figura 8). Isto significa que qualquer fonte de luz artificial que possua azul em sua composição espectral, com comprimento de onda em torno de 480nm, dependendo de sua intensidade, poderá sinalizar ao sistema não visual que é dia.

Comprimentos de onda longos, como por exemplo os da luz vermelha, não exercem atividade sobre o sistema circadiano. Isto confirma, segundo a Dra. Mariana Figueiró ${ }^{13}$, que "nossos olhos são efetivamente detectores de céu azul"(FIGUEIRO et al., 2009).

Ou seja, as células ganglionares intrinsecamente fotossensíveis - descobertas por Berson e seus colegas no ano de 2002 - são estimuladas diretamente pela luz azul, presente em abundância no espectro da luz natural. Isto também significa dizer que a melatonina, principal hormônio do ciclo circadiano, responsável direta ou indiretamente pela secreção de outros hormônios, pode ter sua secreção ou inibição controlada ritmicamente pela exposição à luz azul. A resposta humana à luz para o sincronismo circadiano pode ser também observada em pessoas cegas, mas que possuem intacto o fotorreceptor circadiano (LOCKEY; BRAINARD; CZEISLER, 2003).

Em todos os casos, vale ressaltar que a formação de imagens na retina não é importante para o sistema circadiano, e sim a quantidade de luz que incide sobre ela (REA et al., 2010).

$\overline{13}$ diretora do Centro de Pesquisas em Iluminação do Instituto Politécnico Rensselaer em Troy, Estados Unidos 


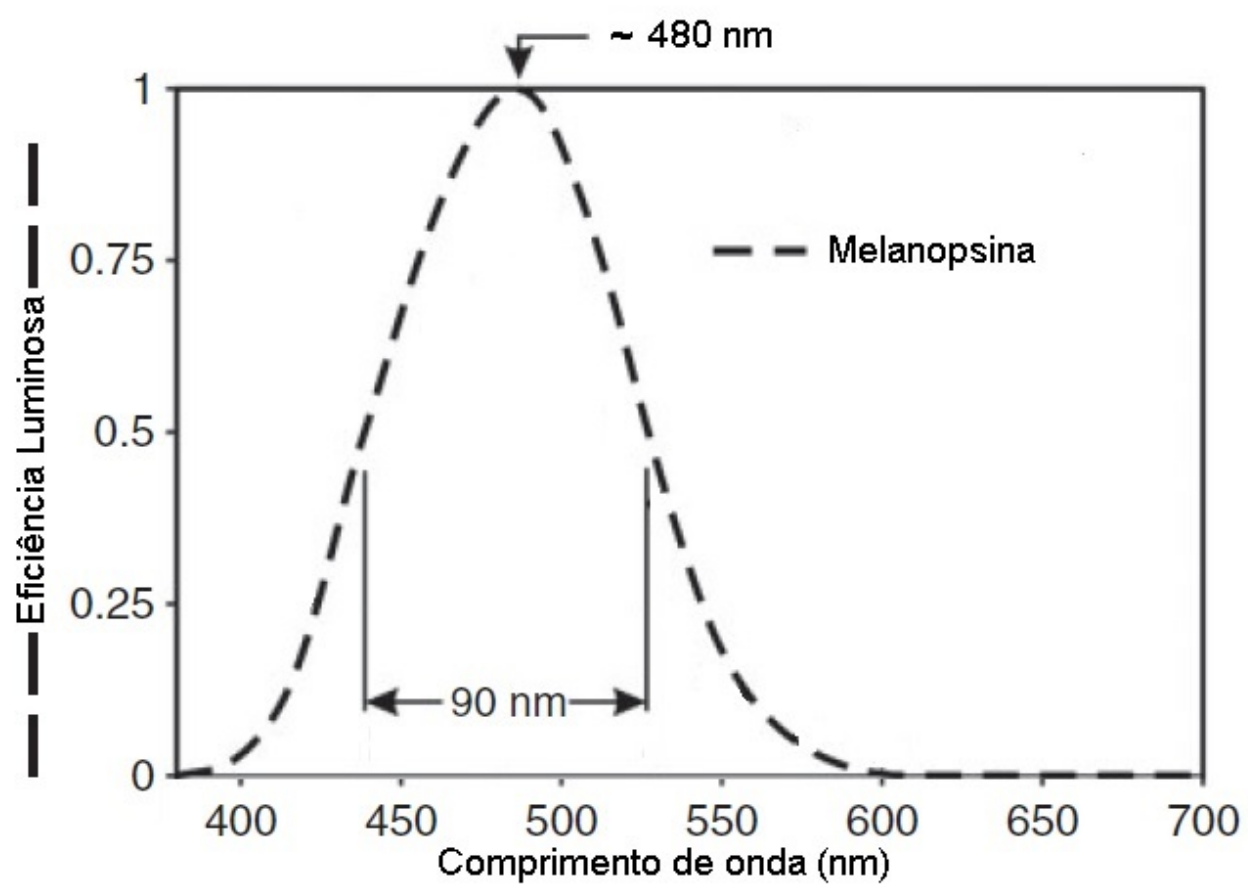

Figura 8 - Curva de sensibilidade espectral do fotopigmento melanopsina. O pico de sensibilidade espectral ocorre em torno de 480nm, com 90nm de largura de banda à meia altura (FWHM - Full Width at Half Maximum). Fonte: modificado de (REA; FIGUEIRO, 2016) 


\section{O Corpo Humano e o Claro-escuro ambien- tal}

Como vimos, para que a organização temporal de nosso organismo ocorra de modo harmônico, é necessário que os ritmos internos estejam sincronizados entre si e ao ciclo de nosso planeta. Vários estímulos podem cumprir esta tarefa, mas o principal Zeitgeber ${ }^{1}$ para manter os mecanismos sincronizados ao dia solar de 24 horas é a luz (FOSTER; KREITZMAN, 2004), que ao incidir na retina, transporta a informação fótica para os núcleos supraquiasmáticos do hipotálamo cerebral (TOSINI et al., 2008).

As constantes variações de dia e noite, ou seja, do claro-escuro ambiental, informam ao organismo não apenas a hora do dia. A amplitude destas variações informam também a época do ano, visto que a duração da porção clara e a duração da porção escura variam a cada dia. Do mesmo modo, como um GPS ${ }^{2}$, também informam a posição exata do indivíduo no planeta (FOSTER; KREITZMAN, 2004, p.95).

Quando acordamos, nosso organismo está preparado para receber a luz do dia. Este é o momento em que a sensibilidade visual humana é maior, ou seja, no início da manhã (TOSINI et al., 2008). Também é o momento em que ocorre a supressão da secreção do hormônio melatonina, que continuará ao longo do dia. Ao meio-dia, a intensidade da luz do sol chega a 100.000 lux (SHIRANI; LOUIS, 2009) e possui alta temperatura de cor, de aparência mais azulada, que provoca o estado de alerta necessário às atividades diurnas. Ao final da tarde, a luz do sol diminui gradativamente de intensidade, é mais amarelada e nos induz ao estado de relaxamento. À noite, a secreção da melatonina nos prepara para funções tipicamente noturnas como o sono.

A luz do sol é o exemplo de iluminação ideal, pois possui alta intensidade e cor azulada durante o dia e baixa intensidade e cor amarelada ao anoitecer (FIGUEIRO, 2010).

Porém, transformações na sociedade moderna, impulsionadas principalmente pela evolução dos sistemas de iluminação artificial, provocaram no ser humano mudanças comportamentais importantes. Atualmente, o ciclo claro-escuro é totalmente diferente do que era para nós há um século. Hoje passamos grande parte do dia no interior de edifícios ou ambientes internos, muitas vezes com total ausência de luz natural e com iluminação artificial incapaz de informar, ao nosso organismo, que é dia. Também ocorre o fato de que cada vez mais desempenhamos atividades noturnas, fazendo com que a iluminação artificial estenda significativamente a porção clara do ciclo claro-escuro (BULLOUGH;

1 do alemão, significa regulador do tempo. Denominamos Zeitgeber todo sincronizador ambiental

2 Sistema de Posicionamento Global 
REA; FIGUEIRO, 2006).

Estas mudanças alteram a duração e o padrão diário de exposição à luz, tornando-o muito longo, muito curto, ou aperiódico, podendo fazer com que o "relógio biológico"perca controle dos sistemas pelos quais é responsável (REA; BIERMAN; FIGUEIRO, 2008). Quando isto ocorre, pode haver alterações em um ou mais ritmos, caso em que dizemos que o indivíduo está fora de fase, e isto pode contribuir para que ocorram vários efeitos nocivos à saúde (MARTAU, 2009). Alterações de fase do ritmo circadiano ou a dessincronização dos ritmos entre si, caracteriza um estado também denominado Cronorruptura.

Os núcleos supraquiasmáticos do hipotálamo cerebral, nosso marcador biológico principal,

controlam vários relógios biológicos do nosso corpo incluindo o fígado, pâncreas, hipófise e vários outros órgãos. Essa coordenação entre o relógio biológico do cérebro e os relógios biológicos periféricos é extremamente importante para que cada órgão do corpo humano execute a tarefa correta na hora correta. Hoje sabemos que a perda desta sincronia entre os relógios biológicos está ligada a problemas de saúde como o câncer, cardiopatias, diabete, obesidade (FIGUEIRO, 2010, p. 9).

A luz, por ser um forte Zeitgeber, pode alterar a produção da melatonina à noite, ou mudar a hora em que começamos a produzi-la. Significa dizer que se a luz for aplicada de manhã, irá avançar ${ }^{3}$ os ritmos circadianos, fazendo com que a pessoa durma mais cedo e acorde mais cedo no dia seguinte. Ao contrário, se a luz for aplicada à noite, atrasará o "relógio biológico", fazendo com que a pessoa durma mais tarde e acorde mais tarde no dia seguinte (FIGUEIRO, 2010). A isto damos o nome de, respectivamente, "avanço de fase" e "atraso de fase" (MARTAU, 2009).

A preponderância da luz como um forte Zeitgeber ocorre porque o fotorreceptor circadiano do olho está, neuroanatomicamente, conectado aos Núcleos Supraquiasmáticos do Hipotálamo cerebral pelo trato retinohipotalâmico, que por sua vez está neuroanatomicamente conectado à glândula pineal, pela via neural que passa pelo gânglio cervical superior, conforme ilustração da Figura 9. Isto significa afirmar que o olho está diretamente "plugado"ao marcador temporal principal de nosso Sistema Nervoso Central.

\subsection{Melatonina: O principal marcador temporal fisiológico}

A conexão mais importante dos núcleos supraquiasmáticos para o ciclo circadiano ocorre pela ação da glândula pineal, que é a principal responsável pela secreção do hormônio melatonina.

A melatonina circula na corrente sanguínea e é facilmente absorvida por células individuais, servindo como elemento de sinalização temporal. Produto do metabolismo 
da serotonina ${ }^{4}$ (AMADO; MAZZACORATTI, 2004), está envolvida na regulação da adaptação à intensidade de luz, nas mudanças diárias no ciclo claro-escuro e nas mudanças sazonais (SOUSA-NETO; SCALDAFERRI, 2005).

A Figura 9 ilustra o esquema completo da fisiologia da síntese de melatonina, desde a incidência de luz na retina, passando pelos núcleos supraquiasmáticos, e sua conexão com a glândula pineal.

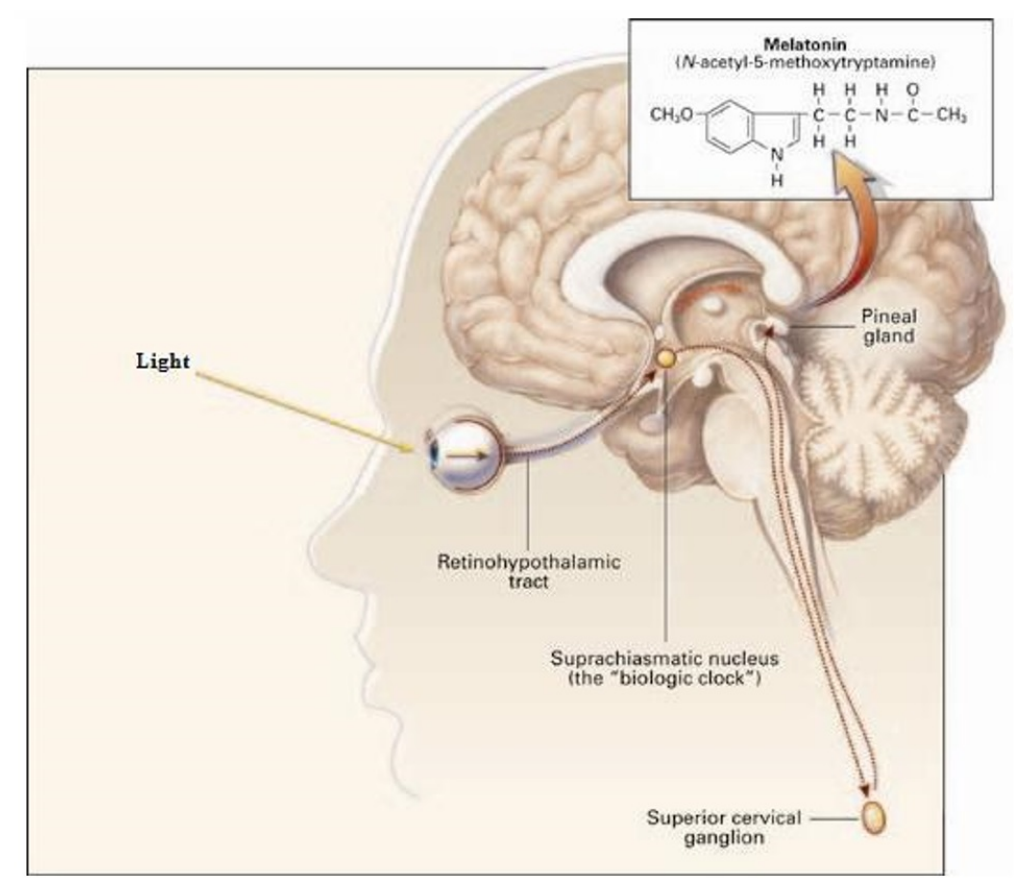

Figura 9 - Fisiologia da Secreção de Melatonina. A melatonina é produzida na glândula pineal. Sua produção e secreção são mediadas principalmente por fibras nervosas pós-ganglionares que passam através do trato retino-hipotalâmico aos núcleos supraquiasmáticos em seguida para o gânglio cervical superior e, finalmente, a glândula pineal. Este sistema neural é ativado pela ausência e reprimido pela incidência de luz na retina. Fonte: Adaptado de (SHIRANI; LOUIS, 2009)

A melatonina é sintetizada diariamente à noite, em condições de ausência de luz, atingindo seu pico entre 2 e 4 horas da madrugada, quando seus níveis se reduzem gradualmente até as menores taxas ocorrerem entre 7 e 9 horas da manhã (FIGUEIRO et al., 2009), ocorrendo a partir daí quase nenhuma síntese no período diurno (SOUSA-NETO; SCALDAFERRI, 2005).

Além das funções já citadas, nos seres humanos a melatonina é responsável pelo aumento da sonolência e pela diminuição da temperatura corporal (SOUSA-NETO; CASTRO, 2008).

Outra importante sinalização temporal ocorre sazonalmente por meio da melatonina. Durante o inverno, temos noites mais longas, fazendo com que o tempo de presença 
da melatonina em nossa corrente sanguínea seja maior. Ao contrário, durante o verão, temos noites mais curtas, fazendo com que o tempo de presença da melatonina em nossa corrente sanguínea seja menor. Esta diferença de amplitude da sinalização diária de melatonina se constitui em uma nova sinalização, que regula nossos ritmos anuais (FOSTER; KREITZMAN, 2004). Este mecanismo informa ao nosso organismo não apenas a época do ano, mas também sua localização no globo terrestre.

A exposição noturna à luz com elevados níveis de iluminâncias promove a supressão aguda de melatonina ${ }^{5}$, enquanto que a exposição a iluminâncias menores promove uma supressão parcial (MYERS; BADIA, 1993).

\subsubsection{Propriedades e ações da melatonina}

A melatonina existe em todos seres desde organismos unicelulares, plantas, fungos e animais (PANDI-PERUMAL et al., 2006). Nos vertebrados e mamíferos, é produzida principalmente na glândula pineal. Uma de suas mais importantes características é que, por ser anfifílica ${ }^{6}$, penetra em todos os compartimentos do organismo. Possui funções imunomodulatórias ${ }^{7}$, anti-inflamatórias ${ }^{8}$, antitumorais ${ }^{9}$, antioxidantes ${ }^{10}$, e cronobióticas $^{11}$ (SOUSA-NETO; CASTRO, 2008).

Como regulador ou sinalizador temporal, a melatonina age principalmente:

- enquanto presente;

- por repetição circadiana;

- pelo tempo de presença;

- após cessar sua presença.

A melatonina é o antioxidante natural mais poderoso, por reagir com radicais livres de hidrogênio e de nitrogênio. Seus principais efeitos moleculares e celulares envolvem mecanismos de reparação celular, proteção celular e mitocondrial, além de regulação de processos enzimáticos e do DNA, regulação de reprodução mitocondrial e regulação da estabilidade, fluidez, permeabilidade e diferença de potencial da membrana celular.

Sua ação ocorre por todo o organismo, de modo sistêmico, pela suas propriedades antitumorais, além de vários tipos de regulação temporal como o ciclo circadiano, o ciclo

\footnotetext{
reduzindo sua síntese a níveis diurnos

6 solúvel tanto em meio lipídico como em meio aquoso

7 atuação no sistema imunológico, conferindo aumento da resposta orgânica contra determinados microorganismos, incluindo vírus, bactérias, fungos e protozoários

8 combate a inflamação dos tecidos

9 combate a tumores

10 capaz de inibir a oxidação de moléculas

11 de regulação temporal
} 
vigília-sono, o metabolismo energético ${ }^{12}$, o sistema cardiovascular ${ }^{13}$, o sistema imunológico, as funções e plasticidade neural ${ }^{14}$, os processos reprodutivos e mediação materno-fetal, desenvolvimento e programação intrauterina e as interfaces do organismo com o meio ambiente ${ }^{15}$.

\footnotetext{
12 ingesta de alimentos, nutrientes de estoque e dispêndio energético

13 regula o ponto de ajuste da Pressão Arterial

14 como neuroproteção e neurogênese

15 pele, retina, tubo gastrointestinal e sistema imunológico
} 


\section{Iluminação arquitetônica e saúde}

A arquitetura fornece a interface entre o ambiente externo e o corpo humano, interferindo diretamente no modo como as pessoas acessam a luz. Assim como a pupila faz o ajuste fino da quantidade de luz que entra no olho (ANDERSEN; GOCHENOUR; LOCKEY, 2013), a arquitetura desempenha um papel importante na regulação da entrada de luz para os ambientes internos.

Tradicionalmente, a iluminação arquitetônica é panejada de modo a prover luz que proporcione melhor desempenho visual (ABNT, 2013), seja visualmente confortável, permita a apreciação estética do espaço e promova a conservação de energia elétrica (LUCAS et al., 2014).

Atualmente, além de propiciar a visão, a consideração dos efeitos não visuais provocados pela luz é de importância crescente no projeto de arquitetura e de iluminação (LESLIE; RADETSKY; SMITH, 2011). É necessário que o planejamento do ambiente construído passe a considerar a influência da luz no ciclo circadiano dos usuários.

\subsection{O papel da arquitetura}

Quando afirmamos a importância de haver a conexão dos usuários do ambiente construído com o meio externo, a arquitetura torna-se um componente de extrema importância, pois a forma das estruturas arquitetônicas e os materiais construtivos utilizados modulam a luz natural que incide nos ambientes e seus componentes como intensidade, duração e espectro, trazendo consequências importantes na temporização e sincronização dos ritmos circadianos (CZEISLER et al., 1999).

A magnitude dos efeitos não visuais a partir de um aumento na luz "visual", dependerá do espectro da luz do dia entrante e da refletividade espectral da pintura das paredes. Tinta com muito ou pouco azul, por exemplo, pode refletir os comprimentos de onda apropriados para o pigmento circadiano no olho (ANDERSEN; GOCHENOUR; LOCKEY, 2013).

\subsubsection{Iluminação natural}

Em um espaço arquitetônico, é a geometria primária que afetará o tempo de incidência de luz natural (ANDERSEN; GOCHENOUR; LOCKEY, 2013). O fato de permanecermos grande parte do dia em locais fechados diminui sensivelmente a robustez do ciclo claro-escuro ao qual estamos expostos. 
O aumento da distância de uma janela, por exemplo, tem sido associado a uma diminuição da produtividade no local de trabalho (BOYCE, 2006), provavelmente pela necessidade de contato com o meio externo.

A visualização deste "potencial circadiano"ao longo do tempo pode oferecer um poderoso apoio ao design dos ambientes (ANDERSEN; GOCHENOUR; LOCKEY, 2013).

\subsubsection{Iluminação artificial}

Mais de um século após a invenção da lâmpada elétrica, nossa sociedade passou por diversas transformações decorrentes da possibilidade crescente de se desempenhar, à noite, atividades anteriormente limitadas pela deficiência de luz após o pôr do sol. $\mathrm{O}$ aperfeiçoamento dos sistemas de iluminação artificial fez com que as pessoas, cada vez mais, estendessem à noite suas atividades sociais, de trabalho e de lazer. Isto significa que o ser humano, de hábitos intrinsecamente diurnos, passou a desenvolver também hábitos noturnos, alterando seu "relógio biológico" interno, pois o marcador circadiano mediado pelo olho humano é notavelmente sensível à luz noturna (ZEITZER et al., 2000).

Baseado nesta informação, por exemplo, pode-se inferir a grande importância de ter um quarto escuro à noite para manter o ritmo circadiano adequado e a manutenção do sono (SIGURDARDOTTIR et al., 2012).

Do mesmo modo que ocorre com o planejamento de luz natural, o potencial de "iluminação circadiana"deve admitir luz artificial com intensidade, espectro, duração e tempo corretos (ANDERSEN; GOCHENOUR; LOCKEY, 2013).

\subsection{Fontes de luz artificial}

Desde a invenção da produção de luz a partir da eletricidade, a lâmpada incandescente teve sua fabricação e uso ampliados durante todo o século passado. A partir da segunda metade do mesmo século, as lâmpadas de descarga também foram amplamente utilizadas. Recentemente, nos últimos 20 anos, outras tecnologias, como lâmpadas fluorescentes compactas, substituíram as lâmpadas incandescentes. Muitas vezes, esta transição tem sido impulsionada pela legislação (TOSINI; FERGUSON; TSUBOTA, 2016). Contudo, todas as tecnologias até hoje utilizadas como fontes de luz artificial consideram apenas a existência do sistema visual.

Os estudos sobre o sistema não visual mostram a necessidade de se conhecer e mais importante - conceber fontes de luz artificial a partir da composição espectral da luz que irradiam.

Ao se comparar duas fontes de luz, aquela capaz de emitir luz cuja composição espectral se aproxime da sensibilidade espectral do sistema não visual (ou seja, aquela que 
emita mais luz azul em torno de 480nm) terá maior "eficácia circadiana"(AL-ENEZI et al., 2011) e exigirá um menor pacote de luz para alcançar os mesmos efeitos fisiológicos que uma fonte com menos luz azul (ANDERSEN; GOCHENOUR; LOCKEY, 2013).

\subsection{O projeto luminotécnico}

Enquanto o local de trabalho é importante na vida diurna, a casa é importante à noite na regulação dos ritmos circadianos, uma vez que é onde ocorre o sono e, portanto, quase toda a noite biológica, quando o corpo é mais suscetível a mudança de fase circadiana (ANDERSEN; GOCHENOUR; LOCKEY, 2013).

Podemos afirmar que, em geral, não nos expomos a um ciclo claro-escuro robusto, pois nossos ambientes internos não foram projetados para promover a ritmicidade circadiana. O mesmo ocorre com nossos ambientes de trabalho, com a iluminação do sistema metroviário e com nossas casas.

Nosso corpo precisa de luz rica em azul especialmente no início da manhã, para estimular os fotorreceptores do sistema não visual, e o contrário (níveis baixos de iluminâncias e/ou luz com pouco azul em sua composição espectral) a partir do final da tarde.

As normas de iluminação contemplam apenas o sistema de visão fotópica com os três tipos de cones, considerando a curva de sensibilidade espectral à luz com pico a 555 $\mathrm{nm}^{1}[\mathrm{~V}(\lambda)]$, quantificado em lux fotópico (ANDERSEN; GOCHENOUR; LOCKEY, 2013), estabelecendo recomendações de níveis de luz necessários para manter uma boa visão, ou iluminância no plano de trabalho (lux). Embora a nova norma brasileira para iluminação de interiores tenha incorporado parâmetros como nível de ofuscamento, índice de reprodução de cores adequados a cada tipo de tarefa visual e uma maior preocupação com os níveis de iluminância tarefa/entorno² (ABNT, 2013), não há ainda padrões normativos que considerem os efeitos não visuais da luz, mediados principalmente pelo fotopigmento melanopsina, que tem uma curva de sensibilidade espectral com pico na faixa do azul visível (480 nm)(ANDERSEN; GOCHENOUR; LOCKEY, 2013).

Dado o que sabemos sobre fotobiologia ${ }^{3}$, sobre cronobiologia ${ }^{4}$, e a partir das ferramentas de simulação computacional de que dispomos atualmente, é possível determinar novos parâmetros para o projeto luminotécnico de modo a verificar, antecipadamente, a participação da luz natural e da luz artificial nos padrões de claro-escuro dos ambientes internos e seu consequente impacto nos usuários.

No ambiente residencial, um estudo demonstrou que a manipulação da intensidade

\footnotetext{
função de eficiência luminosa fotópica

visando evitar o excesso de contrastes

ciência que estuda os efeitos da luz nos seres vivos

ciência que estuda os fenômenos biológicos temporais recorrentes
} 
da luz, com pouca mudança na duração do sono, pode afetar significativamente a modulação circadiana (BURGESS; MOLINA, 2014), embora tal estudo não tenha levado em consideração as características dos sistemas de iluminação artificial utilizados.

\subsection{LEDs}

As restrições de desempenho impostas aos rendimentos das lâmpadas incandescentes e a busca por eficiência energética, aliadas ao desenvolvimento da tecnologia dos LEDs, fez com que estes fossem adotados para praticamente todas as aplicações que necessitem iluminação artificial.

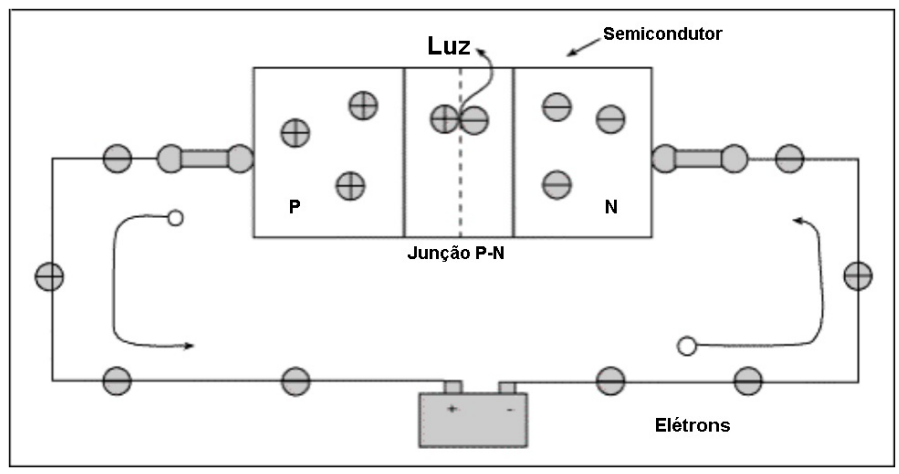

Figura 10 - Ao alimentar a junção PN do LED, os elétrons se movem da área N para a área $\mathrm{P}$ e lacunas da área $\mathrm{P}$ se movem em direção à área N. Perto da junção, os elétrons e as lacunas se combinam, liberando energia sob a forma de luz. Fonte: adaptado de <www.lrc.rpi.edu/programs/nlpip/lightinganswers/led/ whatisanled.asp >

LED, ou Diodo Emissor de Luz ${ }^{5}$, é um componente eletrônico semicondutor em estado sólido, que como qualquer diodo permite a passagem da corrente elétrica em apenas um sentido. Possui dois eletrodos: um carregado positivamente ${ }^{6}$ e outro carregado negativamente, formando uma junção P-N (BIGONI, 2013). Quando uma corrente elétrica é aplicada a este diodo, as partículas são obrigadas a se movimentar em direções opostas, combinando-se umas às outras e liberando fótons, ou seja, Luz, conforme ilustrado na Figura 10, por um processo denominado eletroluminescência ${ }^{7}$.

Os LEDs emitem luz monocromática, cujo comprimento de onda depende do material e do tratamento empregado na fabricação de seus eletrodos. Certamente a evolução tecnológica trará novas técnicas e outros materiais. Até momento, os principais são os seguintes:

\footnotetext{
5 do inglês, Light Emmiting Diode

6 por não possuir elétrons, pode-se referir à carga positiva como lacuna

7 luminescência produzida pela passagem de corrente elétrica
} 
- Luz Vermelha, laranja e amarela é obtida com os materiais Alumínio, Índio, Gálio e Fósforo $^{8}$;

- Luz vede e azul é obtida com os materiais Índio e Nitreto de Gálioº

\subsubsection{A Revolução dos LEDs}

A Iluminação em estado sólido ${ }^{10}$ foi possível a partir do início da década de 1990 com a invenção do LED emissor de luz azul, que rendeu o prêmio Nobel de Física de 2014 aos professores Isamu Akasaki, Hiroshi Amano e Shuji Nakamura. A invenção dos três laureados foi ponto de partida para a criação desta eficiente fonte de luz branca amplamente utilizada no mundo (KRAFTMAKHER, 2015).

O LED de luz branca é essencialmente uma fonte bicromática e ocorre por meio de um LED que emite luz azul (eletroluminescência), cuja curva espectral apresenta pico em torno de 450 a $470 \mathrm{~nm}$ e largura à meia altura (FWHM) ${ }^{11}$ de 30 a 40 nm (NAKAMURA; CHICHIBU, 2000), revestido com um substrato de fósforo de espectro amplo, com pico de emissão (fosforescência) em torno de $580 \mathrm{~nm}$ e largura à meia altura de $160 \mathrm{~nm}$ (TOSINI; FERGUSON; TSUBOTA, 2016), conforme ilustra a Figura 11. A luz branca resulta da adição da luz azul do LED, com a luz convertida em maior comprimento de onda pelo substrato de fósforo.

Os atributos técnicos quantitativos e qualitativos ${ }^{12}$ do $L E D$ branco depende das características do LED azul e do substrato utilizados no conjunto.

A ampla adoção da iluminação em estado sólido ocorreu pela rápida evolução deste componente, especialmente no âmbito de eficiência energética. Os LEDs atuais ultrapassam a eficácia de $200 \mathrm{~lm} / \mathrm{W}$ (KRAFTMAKHER, 2015) e possuem muitas vantagens adicionais em relação às fontes de luz artificial que o antecederam:

- pouca emissão de calor;

- longa vida útil, atualmente entre 50 mil e 100 mil horas;

- menor custo de manutenção;

- não contém elementos tóxicos como mercúrio.

Contudo, os LEDs também apresentam algumas desvantagens:

8 Técnica conhecida como AlInGaP

9 Técnica conhecida como InGaN

10 SSL - Solid State Lighting

11 do inglês, Full Width at Half Maximum, que no nosso caso é a diferença entre o maior e o menor comprimento de onda presente na curca de emissão espectral a $50 \%$ do valor de pico

12 como eficácia $(\mathrm{lm} / \mathrm{W})$, vida útil, temperatura de cor e índice de reprodução de cores 


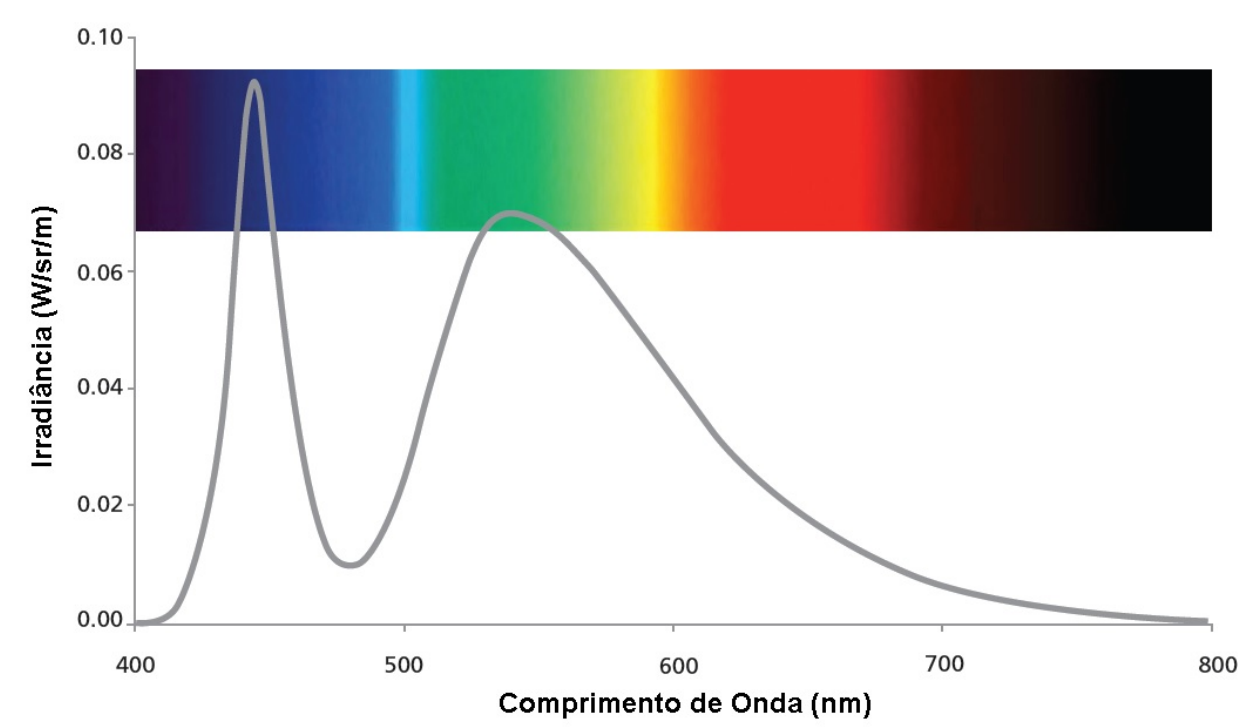

Figura 11 - Curva spectral de um LED de luz branca. Há um pico de emissão de luz azul em torno de $460 \mathrm{~nm}$ (eletroluminescência) e uma emissão secundária mais larga na região de comprimentos de onda mais longos do espectro (fosforescência). Fonte: adaptado de (SPIVEY, 2011)

- maior custo de implantação;

- maior possibilidade de ocorrer flicker ${ }^{13}$ ao se ajustar os níveis de iluminação por meio de sistemas de controle ${ }^{14}$;

- maior dificuldade de reciclagem dos componentes eletrônicos necessários ao seu funcionamento;

- formação de pixels ${ }^{15}$ para alguns sistemas óticos que utilizam muios LEDs;

- maior possibilidade de haver desconforto visual por excesso de luminância ${ }^{16}$;

- Índio, metal utilizado na sua produção, é relativamente raro no planeta;

- maior emissão de luz azul em comparação às demais fontes de luz artificial.

Este último item possui implicações médicas na área de oftalmologia, por um fenômeno amplamente investigado conhecido como "Blue Light Hazard", que é o risco que a luz azul oferece de causar dano fotoquímico na retina por lesão nos fotorreceptores ou por degeneração macular' ${ }^{17}$ (ISA; CSA; CIES, 2013).

A maior emissão de luz azul dos LEDs atuais também possui implicações em cronobiologia, de extrema relevância para este trabalho, conforme abordaremos a seguir.

\footnotetext{
13 oscilações indesejadas de luz, visíveis ou não

14 automação

15 projeção de sombras múltiplas dos objetos iluminados

16 pela emissão de um maior pacote de luz a partir de uma área cada vez menor

17 resultando em ausência de visão ou visão turva no centro do campo visual.
} 


\subsection{Luz e os ritmos biológicos}

Ritmos biológicos são fenômenos endogenamente gerados ${ }^{18}$ em consequência de processos adaptativos a eventos ambientais recorrentes. Geneticamente determinados, estes ritmos são verdadeiros cronômetros internos que todos os seres desenvolveram pela necessidade de viver em um ambiente que se modifica diariamente com uma regularidade infalível.

Os rimos biológicos endógenos se originaram a partir da relação dos organismos com o meio geofísico ambiental e são classificados segundo a frequência com que ocorrem:

- Circadianos, ocorrem a cada período regular de 20 a 28 horas $^{19}$;

- Infradianos, ocorrem em períodos maiores que 28 horas $^{20}$;

- Ultradianos, ocorrem em períodos menores que 20 horas $^{21}$.

Filogeneticamente $^{22}$ somos seres diurnos, pois a sucessão de dias e noites serviram como pressão seletiva, determinando o dia como período de atividade e a noite como período de repouso.

A iluminação artificial modificou o padrão diário de exposição à luz nos seres. A presença de luz à noite ou a falta de luz durante o dia pode alterar o comportamento de animais e o desenvolvimento de plantas. Nos seres humanos, como vimos, o principal regulador temporal possui uma curva sensibilidade espectral à luz de comprimento de onda com pico em 480nm. De todas as fontes de luz artificial utilizadas em iluminação, o LED, pela composição espectral da luz que emite, é a que possui maior capacidade para causar a supressão pineal do hormônio melatonina (Figura 12) e consequentes impactos deletérios na saúde dos usuários ${ }^{23}$. Tendo o LED se tornado a principal fonte de luz artificial para a maior parte das aplicações, torna-se necessário saber até que ponto a iluminação arquitetônica de cada ambiente pode estimular o sistema não visual humano. Deste modo, para pesquisas científicas que investiguem "luz e saúde", é necessário haver meios para quantificar especialmente a porção azul da luz que incide nos olhos dos usuários.

\subsubsection{Quantificando a luz para a sincronização circadiana}

Há duas categorias utilizadas para aferição de luz: radiometria e fotometria. Radiometria busca caracterizar as propriedades físicas da luz em termos de comprimentos de onda

18 se originam no interior do organismo

19 ex: repouso

20 ex: ciclo menstrual feminino

21 ex: pulsos de secreção hormonal, picos de atenção

22 relativo à sucessão genética

23 a partir da exposição noturna 


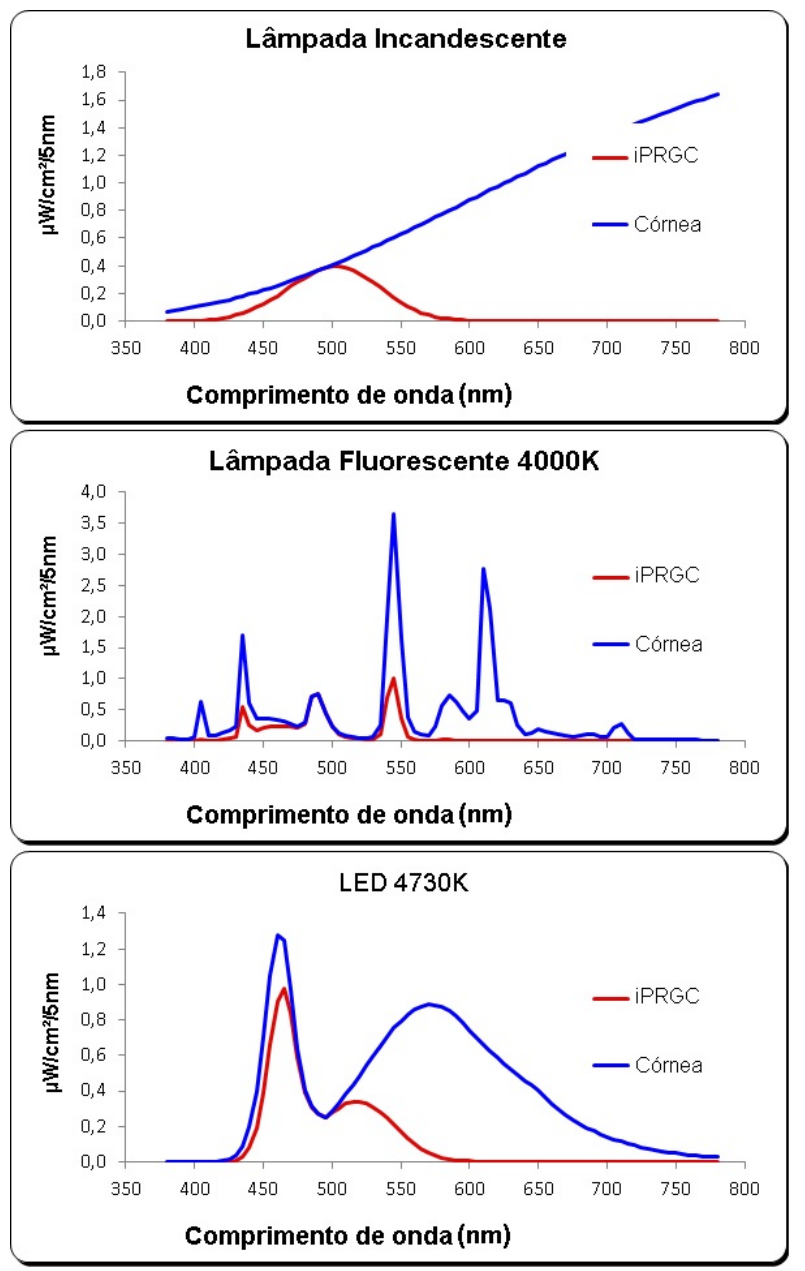

Figura 12 - Comparação entre a composição espectral de três diferentes fontes de luz (linha azul) e sua capacidade de estimular a fotorrecepção circadiana (linha vermelha). Fonte: gráficos gerados no "toolbox"mencionado em (LUCAS et al., 2014)

e energia. Já a fotometria leva em consideração que os fotorreceptores biológicos possuem diferente sensibilidade para cada comprimento de onda. Deste modo, um fotômetro por exemplo, é um radiômetro que utiliza filtros para ajustar as leituras efetuadas, de diferentes comprimentos de onda, à sensibilidade espectral de determinado aspecto do sistema visual humano. Iluminância, cuja unidade é LUX, tem sido uma das grandezas fotométricas amplamente utilizadas para quantificar luz, cuja curva de sensibilidade espectral fotópica apresenta pico em $555 \mathrm{~nm}$, comprimento de onda utilizado como referência para a aferição de equipamentos como o luxímetro e o luminancímetro. Contudo, dadas as diferenças de sensibilidade espectral dos sistemas visual e não visual, se revela inadequada em quantificar luz para este último. Até o momento não foi estabelecida uma grandeza fotométrica específica para o sistema não visual, nem um limiar a partir do qual ele é estimulado (CIE-TN-003:2015, 2013). Tanto a Comissão Internacional de Iluminação ${ }^{24}$ quanto os pesquisadores continuam a buscar um novo padrão, ou uma nova grandeza, que quantifique 24 CIE - Commission Internationale de L'Eclairage 
luz para o ciclo circadiano e para as respostas neurofisiológicas e neurocomportamentais em humanos.

Do mesmo modo que a exposição noturna à luz pode causar danos à saúde, a exposição diurna à luz é necessária para promovê-la. O movimento mundial denominado Human-Centric Lighting ${ }^{25}$ tem mobilizado a indústria de iluminação, os órgãos e associações envolvidos em Lighting Design e os pesquisadores em torno da ideia de que, atualmente, o projeto de iluminação atual necessita

considerar e dar apoio à saúde, ao bem-estar e performance do ser humano pela combinação dos benefícios visuais, biológicos e emocionais da luz (IALD; LIGHTING-EUROPE, 2017).

Na busca em quantificar luz para o sistema não visual, pesquisadores do Instituto Politécnico Rensselaer dos Estados Unidos desenvolveram um modelo matemático para prever a capacidade das fontes de luz artificial em suprimir a síntese de melatonina noturna (REA et al., 2005), denominado $\mathrm{CS}^{26}$.

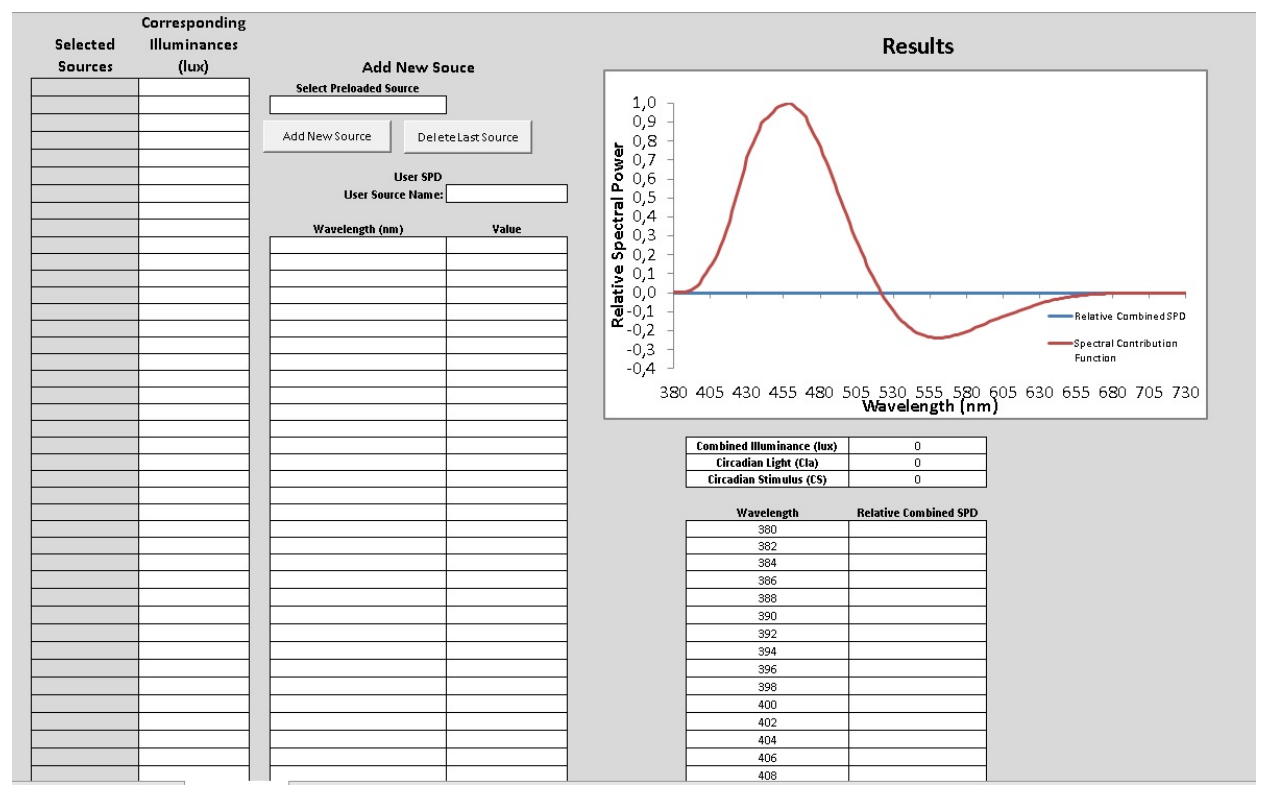

Figura 13 - Calculadora CS, que visa dar suporte aos profissionais de iluminação na seleção de fontes de luz artificial e níveis de iluminância para espaços arquitetônicos adequados ao sistema não visual. Fonte: Página WEB do Lighting Research Center do Instituto Politécnico Rensselaer.

Embora não recomendada pela Comissão Internacional de Iluminação por não ser ainda reconhecida pelo Sistema Internacional de Unidades (CIE-TN-003:2015, 2013, p. 5), a métrica CS tem sido continuamente aperfeiçoada e validada por vários estudos de laboratório, e em aplicações reais com pacientes portadores de Alzheimer e trabalhadores que passam a maior parte do dia em escritórios (REA; FIGUEIRO, 2016). Tais pesquisas

\footnotetext{
25 Iluminação voltada ao ser humano (tradução do autor)

26 Circadian Stimulus
} 
deram origem a uma calculadora denominada Circadian Stimulus Calculator (Figura 13), disponível para download na página eletrônica do Centro de Pesquisas em Iluminação daquele instituto, em <www.lrc.rpi.edu/programs/lightHealth/ $>$.

A falta de uma métrica validada pelo $\mathrm{SI}^{27}$ para quantificar luz para estimulação circadiana fez com que a Comissão Internacional de Iluminação promovesse na Inglaterra o primeiro Workshop Internacional sobre Fotometria Circadiana e Neurofisiológica ${ }^{28}$ (CIETN-003:2015, 2013), que reuniu pesquisadores norte-americanos e europeus na busca de estabelecer um consenso científico condizente com as unidades estabelecidas pelo SI. Embora as discussões promovidas pelo evento não tenham conduzido à formulação de uma métrica, o relatório final procurou sistematizar procedimentos a serem adotados para as pesquisas científicas, para a indústria e para os profissionais de iluminação, na quantificação de luz para o sistema não visual.

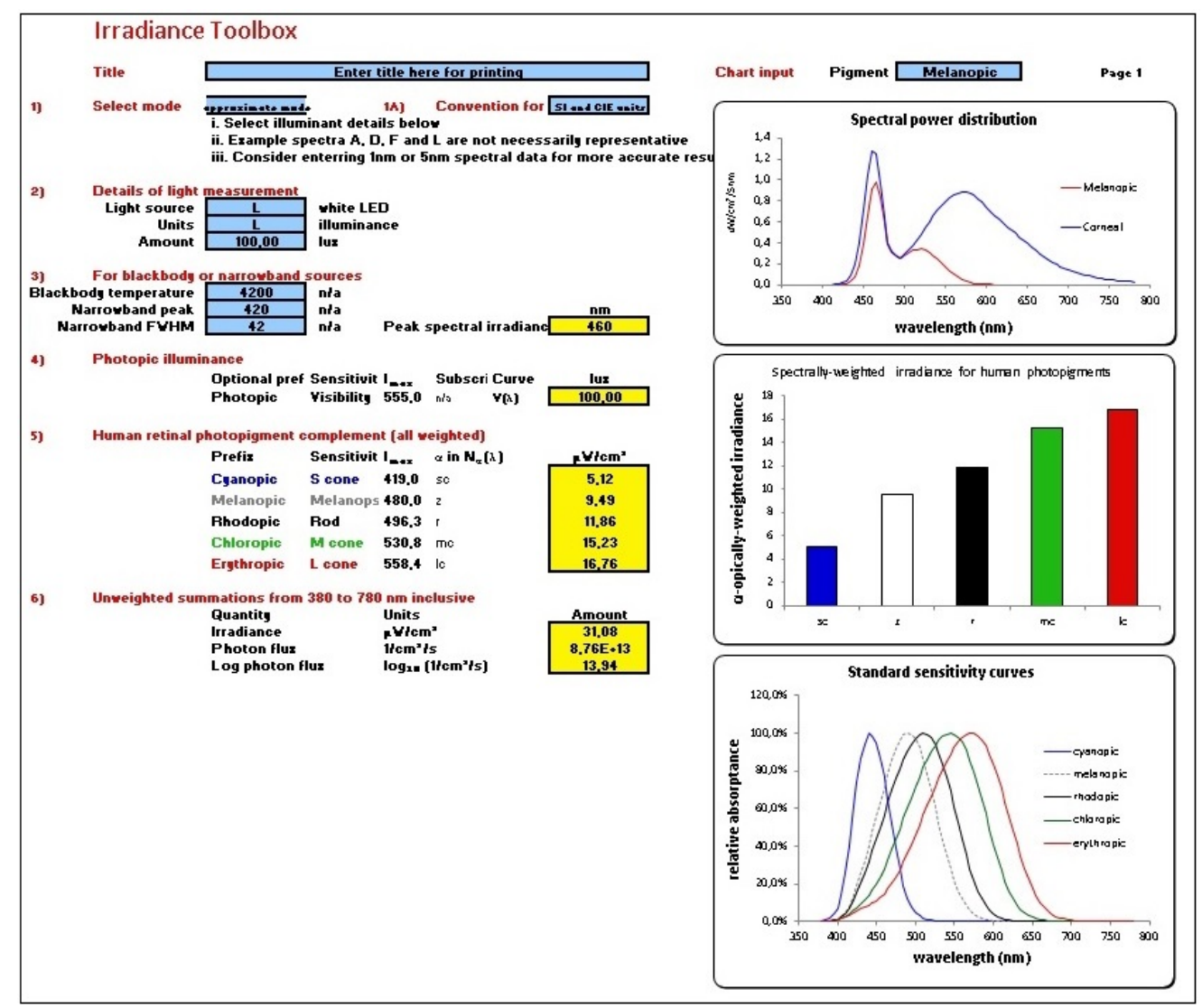

Figura 14 - Toolbox disponibilizado a partir do First International Workshop on Circadian and Neurophysiological Photometry. Fonte: (CIE-TN-003:2015, 2013).

O Workshop da CIE produziu um artigo científico que recomenda o registro, por meio de um espectroradiômetro, da exposição à luz de um modo mais completo como distribuições de energia espectral na córnea. A vantagem de registrar a distribuição de

27 Sistema Internacional de Unidades

28 First International Workshop on Circadian and Neurophysiological Photometry 
energia espectral é que ela pode ser usada para derivar qualquer outra métrica atualmente disponível ou a ser desenvolvida no futuro (LUCAS et al., 2014). O artigo produzido pelo workshop também apresenta uma calculadora denominada Irradiance Toolbox (Figura 14), disponível para download na página da CIE em < http://files.cie.co.at/784_TN003 Toolbox.xls $>$.

Por meio da Irradiance Toolbox é possível verificar, por exemplo, que de 100 lux incidindo diretamente no olho irradia no fotopigmento melanopsina ${ }^{29}$ :

- cerca de $6,57 \mu \mathrm{W} / \mathrm{cm}^{2}$ de energia se a fonte de luz for incandescente;

- cerca de $7,47 \mu \mathrm{W} / \mathrm{cm}^{2}$ de energia se a fonte de luz for fluorescente com temperatura de cor $4000 \mathrm{~K}$;

- cerca de 9,69 $\mu \mathrm{W} / \mathrm{cm}^{2}$ de energia se a fonte de luz for LED com temperatura de cor $4730 \mathrm{~K}$.

$\overline{29}$ a ferramenta não fornece as marcas e os modelos das fontes de luz exemplificadas 


\section{Estudo de caso envolvendo pessoas expos- tas à iluminação noturna com LEDs no am- biente residencial}

\subsection{Características do estudo}

Esta pesquisa visa identificar se a utilização de LEDs para iluminação arquitetônica no ambiente residencial causa impactos deletérios à saúde dos usuários, de modo a justificar o estabelecimento de novos parâmetros a serem observados para o projeto luminotécnico.

\footnotetext{
O estudo de caso é caracterizado pelo estudo profundo e exaustivo de um ou de poucos objetos, de maneira a permitir o seu conhecimento amplo e detalhado, tarefa praticamente impossível mediante os outros tipos de delineamentos considerados (GIL, 2008, p. 58).
}

Trata-se de um estudo de caso transversal ${ }^{1}$, em que cada sujeito foi submetido a um protocolo delineado pelo autor, com a orientação do Prof. Dr. José Cipolla Neto ${ }^{2}$, especialmente para esta pesquisa. Os procedimentos para a coleta de dados foram orientados pelo Prof. Dr. Luiz Menna-Barreto ${ }^{3}$.

\subsection{Metodologia utilizada para a coleta de dados - sujeitos}

\subsubsection{Questionários}

Com o objetivo de conhecer melhor algumas características dos sujeitos, preparamos um formulário online ${ }^{4}$ contendo a ficha cadastral e alguns questionários, cujas informações foram utilizadas como referência durante a fase de análise dos resultados da pesquisa.

\subsubsection{Questionário de cronotipo de Horne e Östberg}

Cronotipo descreve a preferência de cada indivíduo pela matutinidade ${ }^{5}$ ou pela vespertinidade $^{6}$ (Tabela 1 ).

O cronotipo dos sujeitos foi um dos critérios adotados para inclusão em nosso estudo e seu questionário pode ser visto no Anexo B.

\footnotetext{
apresenta um prazo determinado ao observar o fenômeno a ser analisado

diretor do Laboratório de Fisiologia e Biofísica do Instituto de Ciências Biomédicas da USP

3 Coordenador do Grupo Multidisciplinar de Desenvolvimento e Ritmos Biológicos da Escola de Artes, Ciências e Humanidades da USP

4 utilizamos o Google Docs

5 preferência por acordar cedo de manhã e ir dormir cedo à noite

6 preferência por acordar tarde de manhã e ir dormir tarde à noite
} 
Capítulo 5. Estudo de caso envolvendo pessoas expostas à iluminação noturna com LEDs no ambiente residencial

Tabela 1 - Classificação de Cronotipo, segundo Horne e Östberg

\begin{tabular}{|c|c|c|c|c|c|}
\hline \multicolumn{7}{|c|}{ Questionário de Cronotipo - Horne e Östberg } \\
\hline Pontuação & 16 a 30 & 31 a 41 & 42 a 58 & 59 a 69 & 70 a 86 \\
\hline Classificação & $\begin{array}{c}\text { Vespertino } \\
\text { extremo }\end{array}$ & $\begin{array}{c}\text { Moderadamente } \\
\text { vespertino }\end{array}$ & Intermediário & $\begin{array}{c}\text { Moderadamente } \\
\text { matutino }\end{array}$ & $\begin{array}{c}\text { Matutino } \\
\text { extremo }\end{array}$ \\
\hline
\end{tabular}

\subsubsection{Avaliação de transtorno psiquiátrico - Self Reporting Questionnaire - SRQ-20}

A dessincronização circadiana pode causar ou contribuir para distúrbios neurocomportamentais, razão pela qual utilizamos este instrumento, que avalia sintomas como insônia, cansaço excessivo, irritabilidade ou demais fatores que podem indicar a ocorrência de tais distúrbios. No questionário (Anexo C) cada resposta Sim vale 1 ponto. A a soma dos pontos maior ou igual a 7 indica algum tipo de sofrimento mental.

\subsubsection{Avaliação da qualidade do sono - Pittsburg Sleep Quality Index - PSQI}

Este questionário (Anexo D) nos forneceu a informação da existência de distúrbios do sono no período de 30 dias anteriores a este estudo (Tabela 2).

Tabela 2 - Pontuação do Pittsburg Sleep Quality Index

\begin{tabular}{|c|l|}
\hline Pontuação & \multicolumn{1}{|c|}{ Qualidade do sono } \\
\hline 0 a 4 & bom \\
\hline 5 a 10 & ruim \\
\hline$>10$ & presença de distúrbio do sono \\
\hline
\end{tabular}

\subsubsection{Escala de sonolência de Epworth}

Com os mesmos objetivos dos questionários anteriores, este instrumento (Anexo E) serviu para avaliar o grau de sonolência diurna dos sujeitos (Tabela 3).

Tabela 3 - Pontuação da escala de sonolência de Epworth

\begin{tabular}{|c|c|c|c|}
\hline \multicolumn{4}{|c|}{ Escala de sonolência de Epworth } \\
\hline Pontuação & 0 a 10 & 11 a 15 & acima de 16 \\
\hline Classificação & Normal & Média & Ruim \\
\hline
\end{tabular}

Fonte: adaptado de <www.epworthsleepinessscale.com $>$ 
Capítulo 5. Estudo de caso envolvendo pessoas expostas à iluminação noturna com LEDs no ambiente residencial

\subsubsection{6-Sulfatoximelatonina}

Conforme abordado no Capítulo 3, nossos olhos possuem uma via neural ${ }^{7}$ diretamente conectada ao hipotálamo cerebral ${ }^{8}$, e deste à glândula Pineal, que sintetiza à noite o hormônio Melatonina. Isto faz com que, tanto a hora de início quanto a quantidade de secreção de melatonina, sofram influência da luz que incide na retina. O fato de haver esta conexão direta faz com que a supressão da síntese pineal de melatonina, em resposta à luz noturna, ocorra de um modo mais imediato, podendo ser observada durante o período de exposição.

O horário de início da síntese de melatonina, denominado DLMO $^{9}$ ocorre em humanos tipicamente por volta das 21h00m (MYERS; BADIA, 1993), e pode ser verificado por meio de coletas sucessivas de saliva, analisadas posteriormente em laboratório. Embora revele com maior precisão a total ou parcial supressão pineal de melatonina, como resposta à presença de luz noturna, este processo não foi adotado por questões de logística.

Como alternativa, observamos variações na carga de melatonina produzida durante todo o período noturno, por meio da dosagem de seu principal metabólito ${ }^{10}$, a 6-sulfatoximelatonina, que é excretada na urina, conforme ilustrado na Figura 15. As amostras de urina foram coletadas ao longo do estudo e enviadas para posterior análise pelo Instituto de Ciências Biomédicas da USP.

\subsubsection{Temperatura corporal}

As oscilações de temperatura corporal ocorrem de modo sincronizado com nosso marcador temporal principal, apresentando forte ligação com outros ritmos, como o de melatonina, sono-vigília e outros, sendo um importante indicador de eventual avanço de fase ou atraso de fase de nossos ritmos diários. Diferente do que ocorre com a melatonina, o ritmo de temperatura corporal possui maior capacidade de autossustentação, sendo que sua resposta a alterações do padrão de exposição à luz noturna pode ocorrer apenas alguns dias após o estímulo (ASCHOFF, 1993).

Cada ciclo deste ritmo se manifesta com o aumento da temperatura corporal a partir das 06h00m até o final da tarde, uma diminuição ao longo da noite a partir das 23h00m, com as temperaturas mínimas ocorrendo por volta das 04h30m (CORNELISSEN, 2014, p. 302). O horário em que se concentram as temperaturas mais elevadas é denominado Acrofase; o horário em que se concentram as menores temperaturas é denominado Batifase; o tempo decorrido entre duas acrofases é denominado Período; a linha média

7 trato retino-hipotalâmico

8 nosso principal marcador temporal

9 Dim Light Melatonin Onset

10 produto resultante do metabolismo de uma determinada substância 
Capítulo 5. Estudo de caso envolvendo pessoas expostas à iluminação noturna com LEDs no ambiente residencial

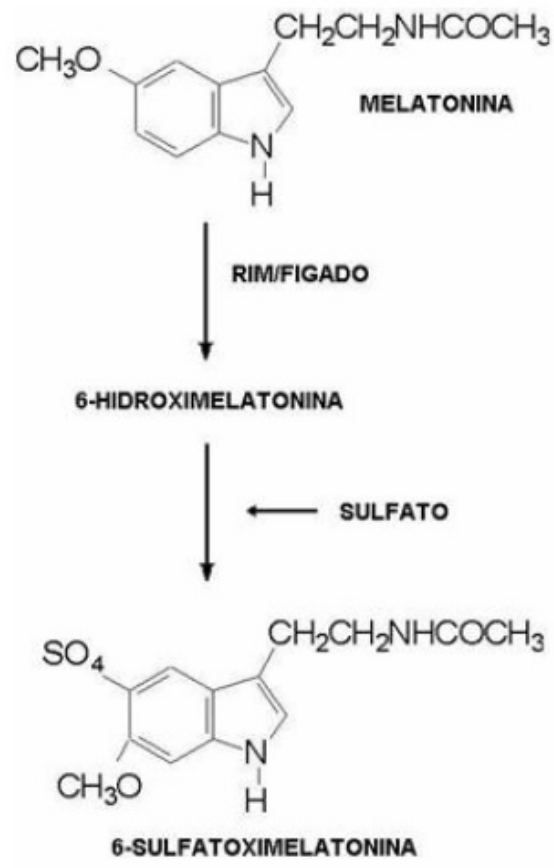

Figura 15 - Metabolização da Melatonina. Fonte: (BORGES, 2006).

estatisticamente ajustada é denominada $M E S O R^{11}$; a distância entre os picos máximo e mínimo é denominada Amplitude (Figura 16).

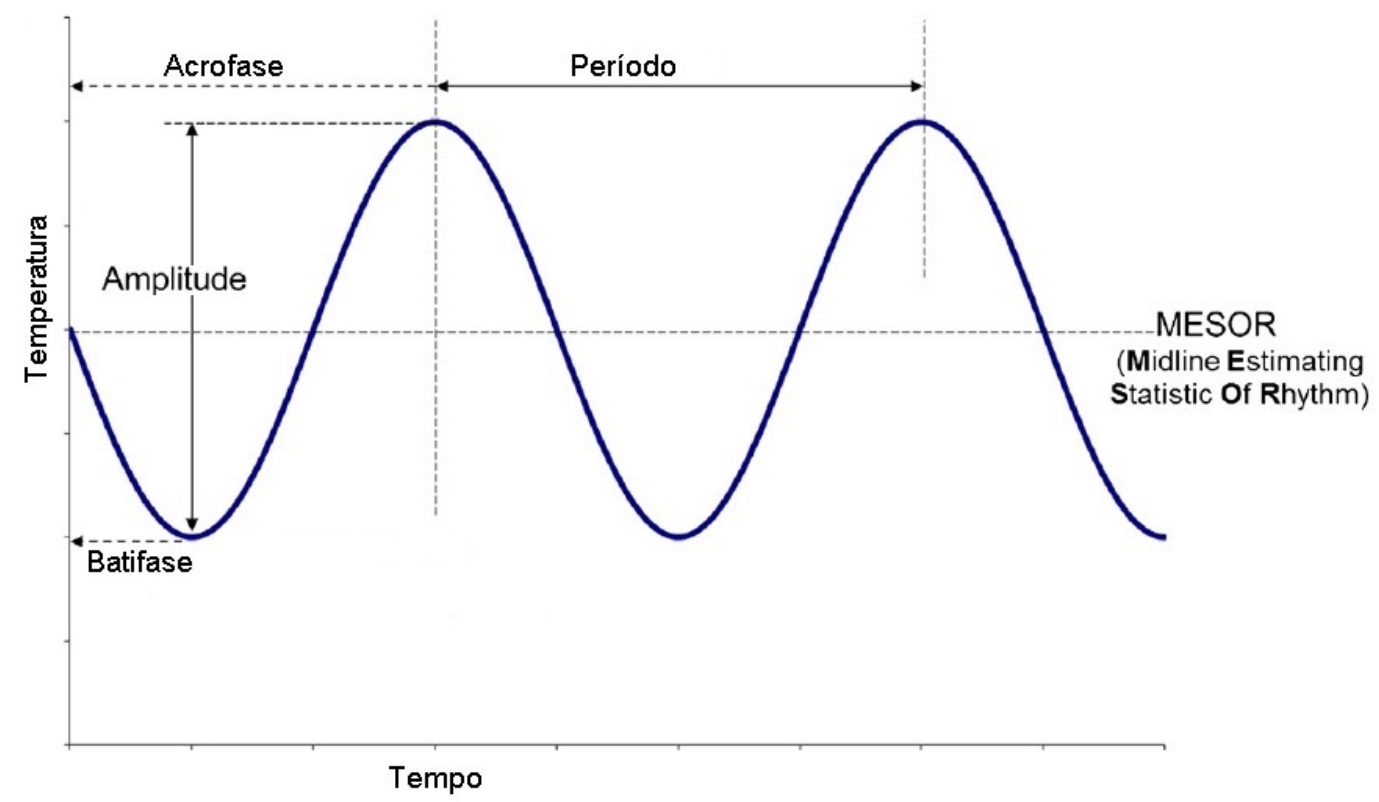

Figura 16 - Curva com as oscilações do ritmo de temperatura corporal e suas características. Fonte: Adaptado de (CORNELISSEN, 2014).

No ser humano, a temperatura retal é a que melhor representa a temperatura 11 Midline Estimating Statistic of Rhythm 
Capítulo 5. Estudo de caso envolvendo pessoas expostas à iluminação noturna com LEDs no ambiente residencial

corporal central, mas sua aferição contínua se mostra inviável para a coleta de séries temporais, razão pela qual muitos autores recomendam o uso de um pequeno coletor de dados que possui um sensor de temperatura ${ }^{12}$ acoplado, fixado na parte anterior do punho não dominante, técnica que se demonstra confortável para os sujeitos e robusta para o ritmo que representa (AREAS; DUARTE; MENNA-BARRETO, 2006). A diferença é que a temperatura periférica oscila em fase oposta em relação à temperatura central. Portanto, a acrofase ${ }^{13}$ da temperatura periférica é observada quando ocorre a batifase ${ }^{14}$ da temperatura central e vice-versa.

Utilizamos para nosso estudo um coletor de dados denominado iButton da marca Maxim Integrated modelo DS1921H. Com dimensões bem reduzidas $(17,35 \mathrm{~mm}$ de diâmetro por $5,89 \mathrm{~mm}$ de altura), possui num mesmo encapsulamento um sensor de temperatura (termístor), bateria e memória para armazenamento dos dados coletados. O iButton possui as seguintes características técnicas:

- relógio de tempo real para o registro de data e hora de cada dado coletado;

- resistência à água;

- leituras programáveis em intervalos de 1 a 255 minutos;

- registra temperaturas de $15^{\circ} \mathrm{C}$ a $46^{\circ} \mathrm{C}$;

- 4Kb de memória para armazenamento dos dados;

- resolução de $0.125^{\circ} \mathrm{C}$;

- comunicação com o computador por meio de um leitor digital ${ }^{15}$ USB e software proprietário $^{16}$.

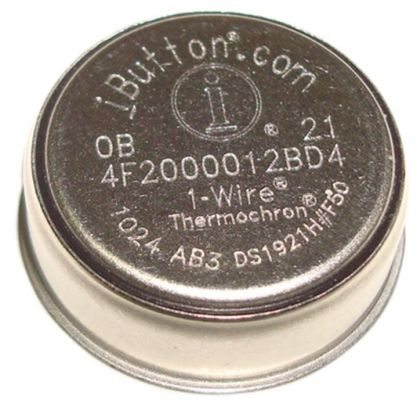

Figura 17 - Maxim iButton Thermochron modelo DS1921H5. Fonte: <www. maximintegrated.com/en/products/digital/data-loggers/DS1921Z.html>

\footnotetext{
12 termístor

13 maiores temperaturas

14 menores temperaturas

15 1-Wire Adapter modelo DS9490B

16 1-Wire Viewer
} 
Capítulo 5. Estudo de caso envolvendo pessoas expostas à iluminação noturna com LEDs no ambiente residencial

\subsubsection{Actimetria}

Os núcleos supraquiasmáticos do hipotálamo cerebral, a partir da estimulação fótica proveniente do claro-escuro ambiental, também controlam nosso ritmo de atividaderepouso (HIGGINS; HORNICK; FIGUEIRO, 2010). A exposição à luz noturna também pode causar distúrbios de sono, razão pela qual se faz necessário avaliar alterações que a iluminação noturna pode provocar.

A actimetria é uma técnica não invasiva, utilizada para facilmente monitorar a atividade motora e, consequentemente, o ritmo de atividade-repouso, capaz de demonstrar alterações deste ritmo. A microeletrônica possibilitou o surgimento de equipamentos wearables ${ }^{17}$ que possuem internamente um acelerômetro ${ }^{18}$ para perceber qualquer tipo de movimento em três planos perpendiculares que correspondem aos eixos horizontal, vertical e axial ${ }^{19}$.
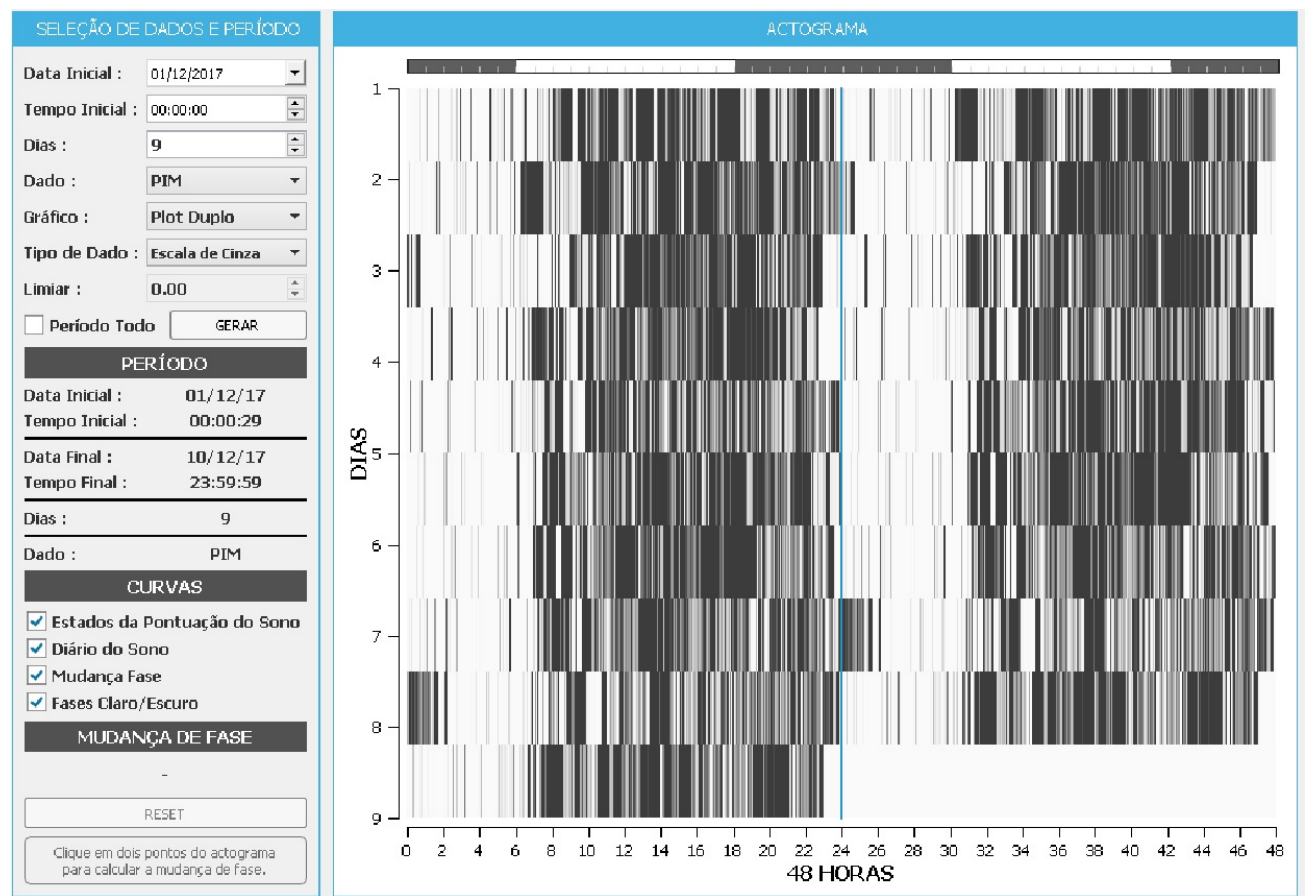

Figura 18 - Tela do software ActStudio mostrando o Actograma de um dos sujeitos do estudo de caso.

Os dados de atividade e repouso podem ser traduzidos em um gráfico denominado Actograma (Figura 18), que permite a visualização gráfica do claro-escuro ambiental e a representação de todos os movimentos do usuário, tornando possível a observação da regularidade do ritmo e a caracterização de eventuais distúrbios.

O actímetro é um coletor/armazenador de dados que, por meio de um acelerômetro

\footnotetext{
17 vestíveis

18 componente eletrônico que converte movimento mecânico em sinais elétricos

19 eixos X, Y e Z
} 
Capítulo 5. Estudo de caso envolvendo pessoas expostas à iluminação noturna com LEDs no ambiente residencial

triaxial $^{20}$, registra todos os movimentos do usuário.

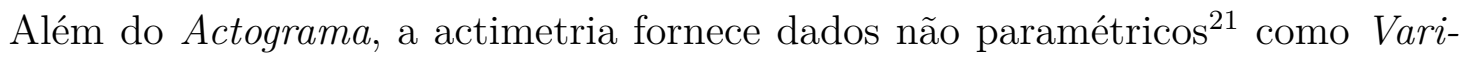
abilidade Intradiária (IV), Estabilidade Interdiária (IS), 10 horas de maior atividade (M10) e 5 horas de menor atividade (L5) (GONÇALVES et al., 2015). IV quantifica a fragmentação do ritmo atividade-repouso; IS quantifica a regularidade do ritmo em relação ao claro-escuto ambiental; $L 5$ se refere à eficiência do sono e M10 se refere à atividade diurna.

Nossa pesquisa utilizou actímetros em forma de relógio de punho da marca Condor Instruments modelo ActTrust (Figura 19), gentilmente fornecidos pelo Grupo Multidisciplinar de Desenvolvimento e Ritmos Biológicos da Escola de Artes, Ciências e Humanidades da USP. O ActTrust é resistente à água e possui uma "Doca" ${ }^{22}$ para configurar cada equipamento, recarregar sua bateria e fazer download de dados, além do software ActStudio, destinado a todas as tarefas descritas acima mais o processamento e análise dos dados coletados.

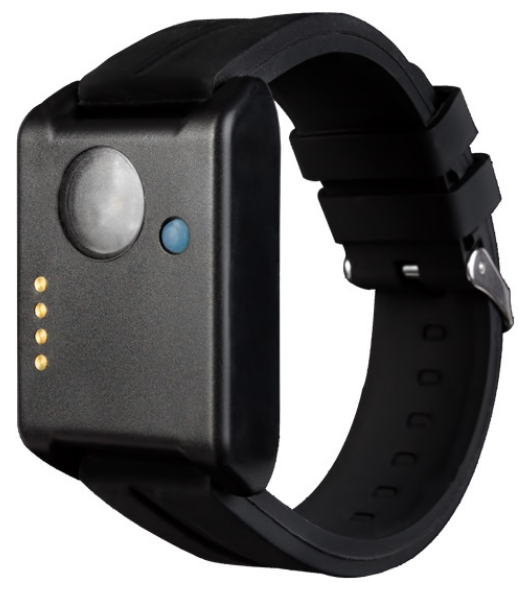

Figura 19 - Actímetro ActTrust da Condor Instruments. Fonte: <www.condorinst.com. br>

\subsubsection{Simulação de fase escura para a coleta de dados - Óculos bloqueadores de luz azul}

Conforme veremos na descrição do protocolo do estudo de caso, para a análise do impacto da iluminação com o uso de LEDs necessitávamos produzir um período de noite biológica, ou seja, submeter os sujeitos a um período de ausência, para o sistema não visual, de luz noturna. Como nosso "Master Clock" ${ }^{23}$ é predominantemente sensível à luz

\footnotetext{
20 referente a três Axis

21 não seguem os parâmetros regulares de muitas variáveis biológicas, como por exemplo, a temperatura corporal

22 interface para comunicação de dados com o computador via porta USB

23 marcador principal dos ritmos biológicos
} 
Capítulo 5. Estudo de caso envolvendo pessoas expostas à iluminação noturna com LEDs no ambiente residencial

azul, os efeitos da luz sobre ele podem ser controlados pelo bloqueio da porção azul da luz visível (SASSEVILLE et al., 2006).

Selecionamos cinco modelos diferentes de óculos (Figura 20), com lentes amarelas e laranja, comercializados como protetores para profissionais que trabalham com equipamentos que emitem radiação ótica com comprimentos de onda curtos. Os óculos foram levados ao Laboratório de Fotometria do Instituto de Energia e Ambiente da Universidade de São Paulo, onde foi feita a análise espectral da luz filtrada por cada um. Os testes foram efetuados com o uso de 2 fontes de luz: LEDs com temperatura de cor nominal de $3000 \mathrm{~K}^{24}$ (branco quente) e LEDs com temperatura de cor nominal de $6000 \mathrm{~K}^{25}$ (branco frio), ambos com $\operatorname{IRC}^{26}$ aferido $>80$.

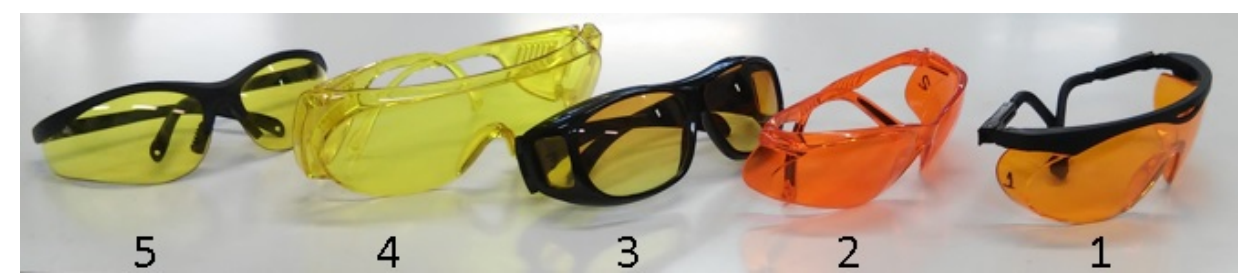

Figura 20 - Óculos testados no Laboratório de Fotometria do IEE-USP. Fotografia: Rose Raad

Para as aferições, foi utilizado um espectrorradiômetro marca Instrument Systems modelo CAS 140 CT. A Figura 21 mostra os equipamentos e a sala de testes do laboratório. A distribuição espectral das fontes de luz utilizadas pode ser vista na Figura 22.

A partir dos testes de laboratório, selecionamos para nossa pesquisa os óculos de número 1 (Figura 20), da marca Honeywell Uvex modelo Skyper ${ }^{27}$, que atendeu com vantagem às nossas exigências, pois possui ajustes de tamanho e inclinação das hastes e proteção contra a entrada de luz pelas laterais de suas lentes, além de atender aos padrões ANSI Z87.1-2015 no design, performance e segurança. A Figura 23 mostra as distribuições espectrais resultantes da luz emitida pelos LEDs de 3000K e de 6000K após ser filtrada pelos óculos bloqueadores de luz azul.

\subsubsection{Exposição à luz}

A antiga norma brasileira de iluminância de interiores (ABNT, 1992) definia que as aferições de iluminâncias devem ocorrer no nível referente a um plano horizontal a $75 \mathrm{~cm}$ do piso. A norma que a cancelou e a substituiu (ABNT, 2013) estabelece o mesmo, embora se refira apenas a ambientes de trabalho.

\footnotetext{
24 temperatura de cor aferida: $3119 \mathrm{~K}$

25 temperatura de cor aferida: $6209 \mathrm{~K}$

26 Índice de Reprodução de Cores

27 código do fabricante: S1933X
} 
Capítulo 5. Estudo de caso envolvendo pessoas expostas à iluminação noturna com LEDs no ambiente residencial

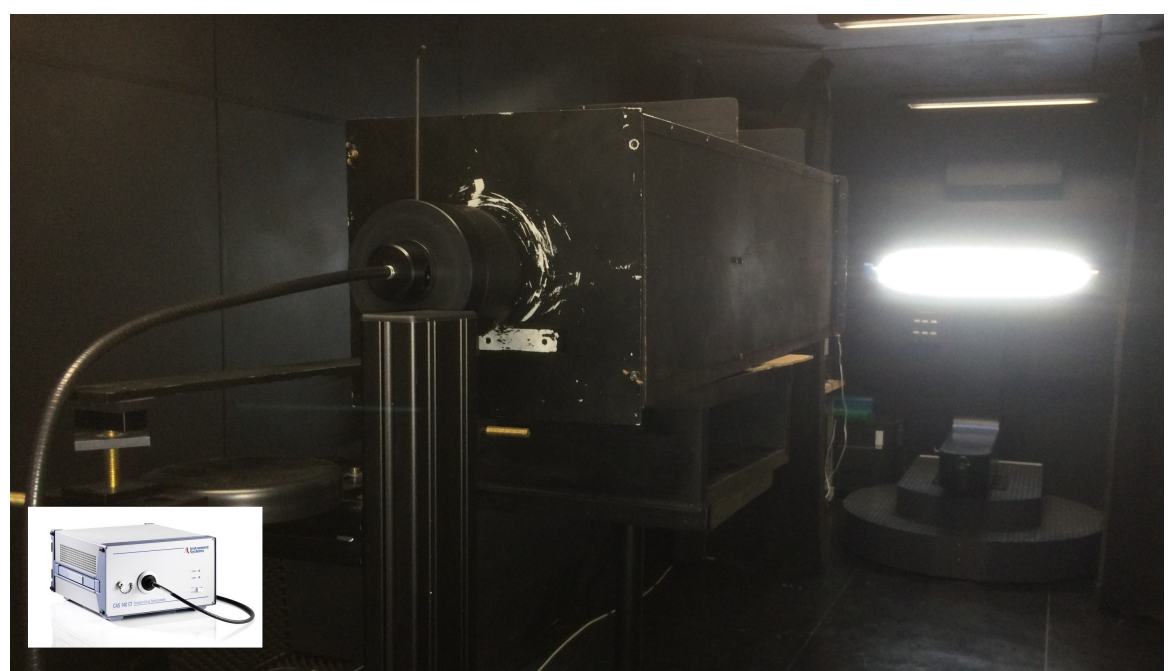

Figura 21 - Espectrorradiômetro (detalhe). Na foto vemos à direita a fonte de luz para os testes e no centro a caixa que contém, no fundo, a fotocélula. Os óculos foram posicionados dentro desta caixa, o mais próximo possível da fotocélula. Fotografia: o autor
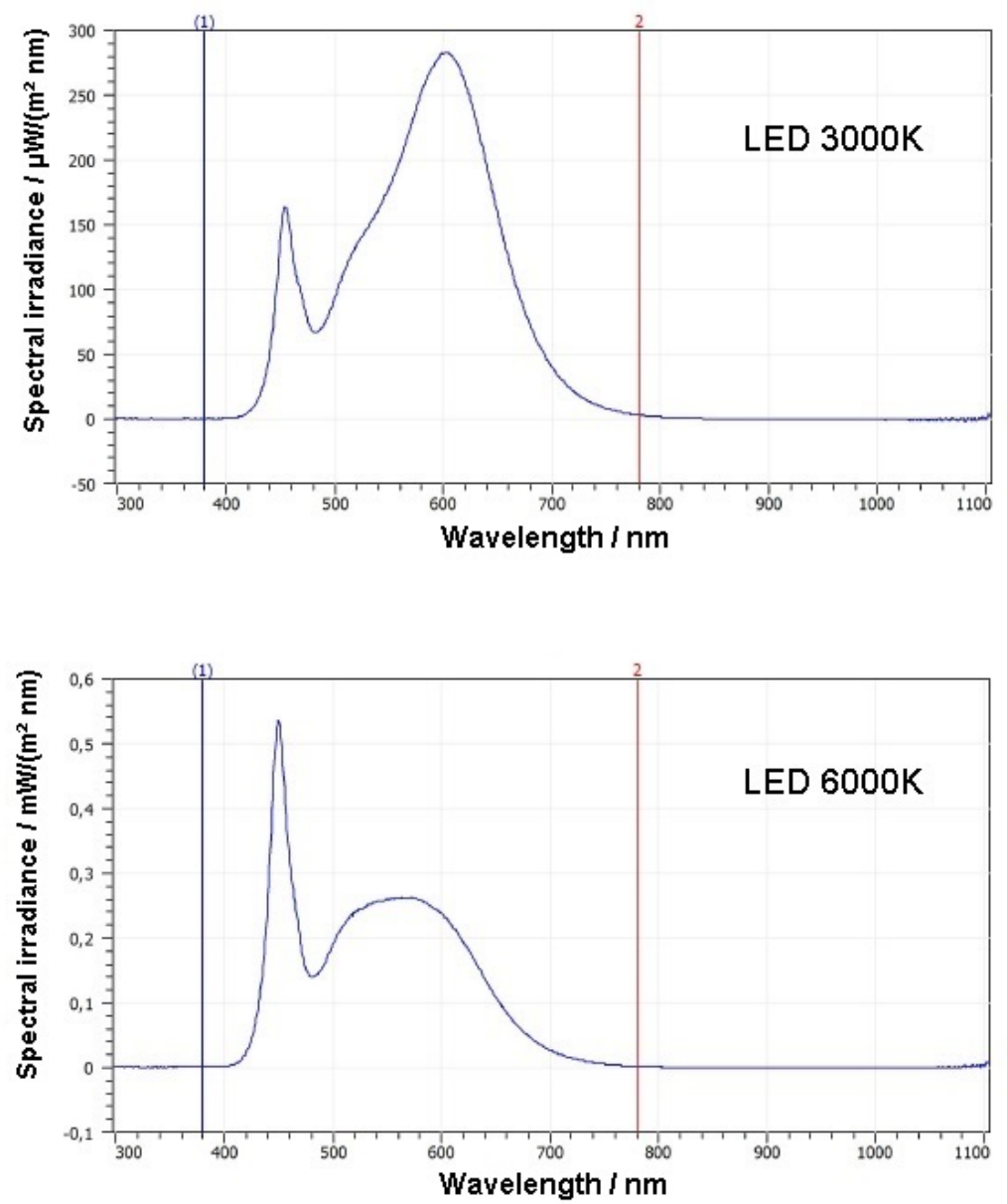

Figura 22 - Distribuição espectral dos LEDs utilizados nos testes dos óculos bloqueadores de luz azul. Fonte: Relatório emitido pelo IEE-USP 
Capítulo 5. Estudo de caso envolvendo pessoas expostas à iluminação noturna com LEDs no ambiente residencial
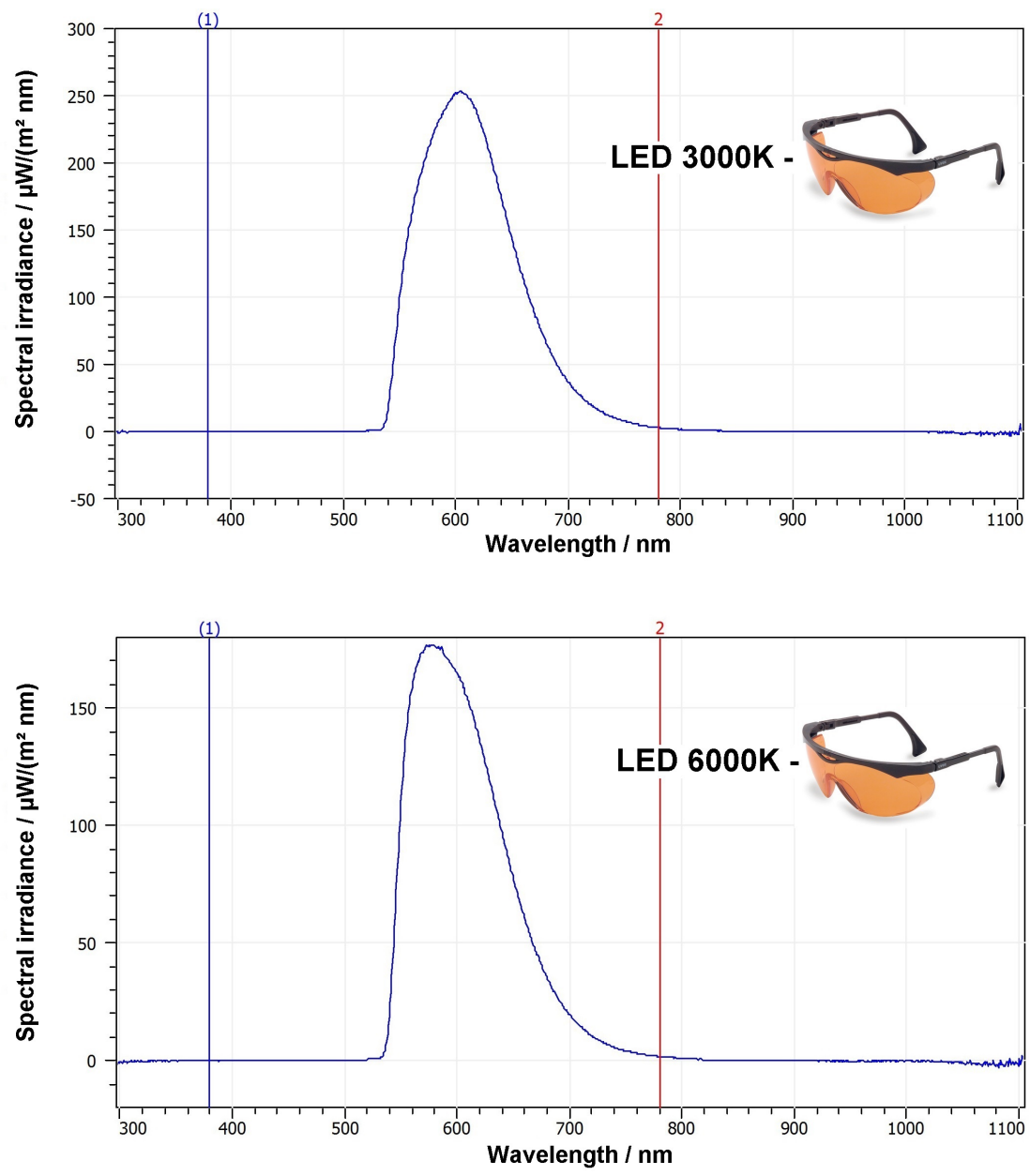

Figura 23 - Distribuição espectral resultante da luz dos LED utilizados nos testes, filtrada pela lente dos óculos bloqueadores de luz azul. Fonte: Adaptado do Relatório emitido pelo IEE-USP

Nosso estudo previu o levantamento de iluminâncias dos ambientes residenciais de maior permanência à noite, mas era necessário também aferir as iluminâncias que efetivamente incidem nos olhos dos usuários, no plano vertical, que revelam com maior precisão seu padrão de exposição à luz, verificado por meio de um pequeno equipamento que coleta e armazena os dados coletados por uma fotocélula. Trata-se de um wearable 28 concebido para aferir iluminância (em lux), no plano vertical, o mais próximo possível dos olhos do usuário. O dispositivo foi programado para ler e registrar, a cada minuto, o nível de iluminância no plano vertical.

Adotamos o equipamento mostrado na Figura 24, da marca Onset HOBO, modelo UA-002-64, resistente à água, que foi usado no pescoço, como um pendente. O HOBO possui uma interface ótica ${ }^{29}$ conectada à porta USB de computadores, para programação e download dos dados por meio de seu software, o Hoboware, e possui as seguintes

\footnotetext{
28 dispositivo eletrônico que pode ser utilizado no corpo como um acessório

29 marca ONSET modelo BASE-U-1
} 
Capítulo 5. Estudo de caso envolvendo pessoas expostas à iluminação noturna com LEDs no ambiente residencial

características técnicas:

- relógio de tempo real para o registro de data e hora de cada dado coletado;

- resistência à água;

- leituras programáveis em intervalos a partir de 1 segundo;

- registra iluminâncias de 0 a 320.000 Lux;

- 64Kb de memória para armazenamento dos dados;

- comunicação com o computador por meio de um acoplador ótico (BASE-U-1) USB e software proprietário ${ }^{30}$.

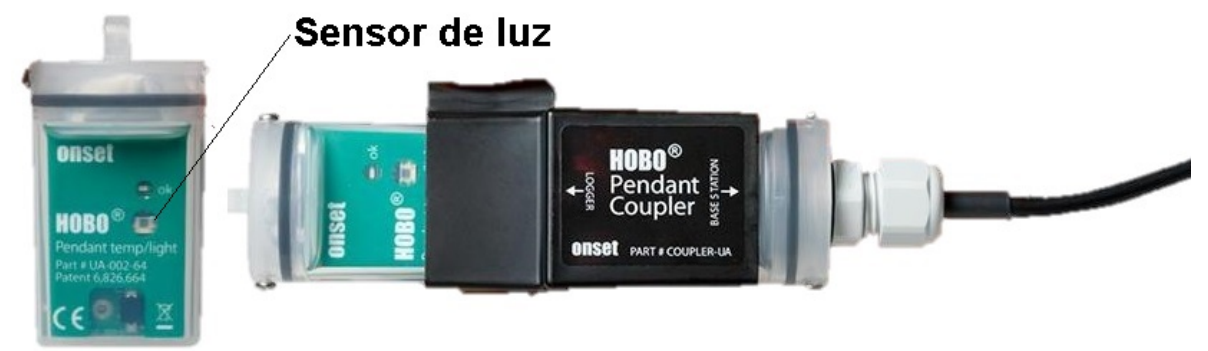

Figura 24 - Coletor de dados HOBO e respectivo acoplador para a programação e comunicação de dados. Fonte: Adaptado de <www.onsetcomp.com/products/ data-loggers/ua-002-64>.

30 HoboWare 
Capítulo 5. Estudo de caso envolvendo pessoas expostas à iluminação noturna com LEDs no ambiente residencial

\subsection{Metodologia utilizada para a coleta de dados - ambientes}

Os ambientes de maior permanência à noite foram analisados a partir do levantamento fotométrico e de imagens fotográficas, conforme descrito a seguir:

\subsubsection{Características dos sistemas e iluminâncias}

Para cada ambiente foi realizado um levantamento fotométrico com a aferição da iluminância média, temperaturas de cor e os tipos de sistemas de iluminação instalados. As aferições de iluminância foram executadas por meio da leitura de uma malha de pontos a $75 \mathrm{~cm}$ do piso. Utilizamos um luxímetro marca Icel modelo LD-550 (Figura 25).

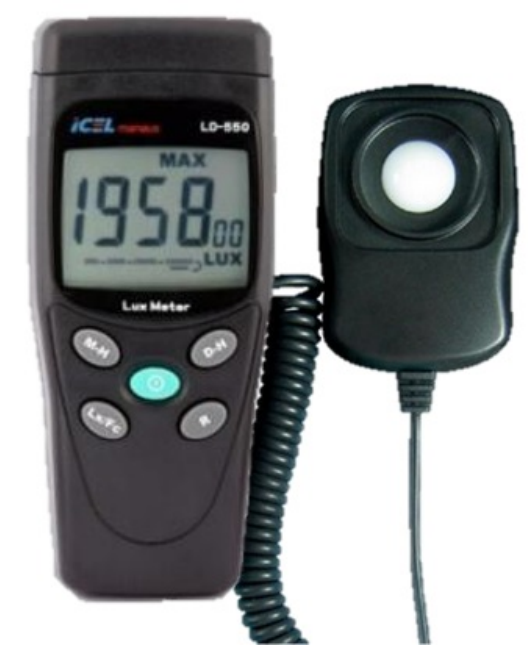

Figura 25 - Luxímetro digital utilizado para o levantamento fotométrico dos ambientes residenciais de maior permanência à noite. Fonte: Adaptado de $<$ www. icel-manaus.com.br>.

\subsubsection{Luminâncias}

A Norma brasileira de Iluminação de ambientes de trabalho (ABNT, 2013) incorporou novos parâmetros qualitativos e quantitativos, necessários à prática de uma boa iluminação, como o Índice de Ofuscamento, ou $\mathrm{UGR}^{31}$, observando que

\footnotetext{
ofuscamento é causado por luminâncias excessivas ou contrastes no campo de visão e pode prejudicar a visualização dos objetos (ABNT, 2013, p. $6)$.
}

Contudo, a norma não menciona que luminâncias excessivas podem impactar nosso sistema não visual, sendo mais um importante parâmetro para o projeto luminotécnico que observa a relação da luz com a saúde dos usuários, razão pela qual verificamos, para todos os ambientes estudados, os níveis de luminância.

31 Unified Glare Rating 
Capítulo 5. Estudo de caso envolvendo pessoas expostas à iluminação noturna com LEDs no ambiente residencial

Quantificar luminância torna-se um desafio, pois seus níveis dependem da posição do usuário no ambiente e da direção de seu olhar, razão pela qual adotamos um recurso de fotografias High Dinamic Range (HDR) (GOEDERT; PEREIRA, 2017), que nos permite capturar os valores de luminância de uma imagem ao mesmo tempo (MIRI, 2015).

Adotamos o aplicativo Aftab Luminance, para o sistema operacional IOS, instalado em um tablet da marca Apple modelo IPAD. O software foi aferido por meio de um luminancímetro, marca Topcon modelo BM-8 gentilmente fornecido pela empresa Itaim Iluminação para esta pesquisa (Figura 26).

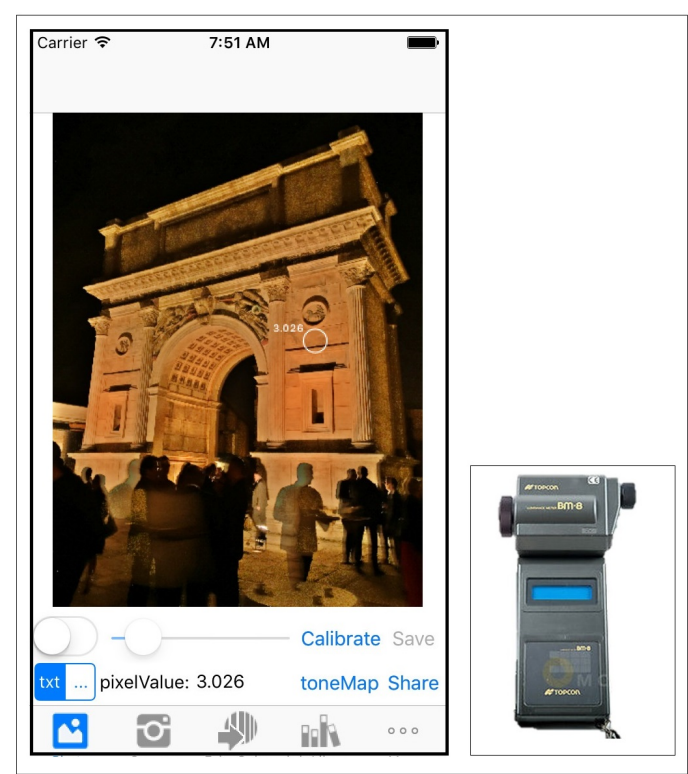

Figura 26 - Tela do aplicativo Aftab Luminance, com foto do luminancímetro utilizado na sua aferição (detalhe). Fontes: < http://aftabsoft.net/ $>$ e $<$ www. topcon-techno.co.jp/en/>.

\subsubsection{Luz azul}

A etapa de coleta de dados incluiu, no levantamento fotométrico, fotografias com um filtro para visualmente inspecionar a luz azul nos ambientes.

A partir de pesquisa no mercado de lentes e filtros óticos, encontramos um filtro passa-faixa $^{32}$ (Figura 27), que permite a passagem de luz (Figura 28) com comprimentos de onda próximos à curva de sensibilidade do receptor circadiano humano.

Suas características são:

- Fabricante: Edmund Optics;

- Pico de transmitância: 450nm;

32 permite a passagem de uma faixa determinada de comprimentos de onda 
Figura 27 - Filtro passa-faixa: azul. Fonte: <www.edmundoptics.com>

- Largura à meia altura (FWHM - Full Width at Half Maximum): 80nm;

- Dimensões: $12 \mathrm{~mm}$ de diâmetro.

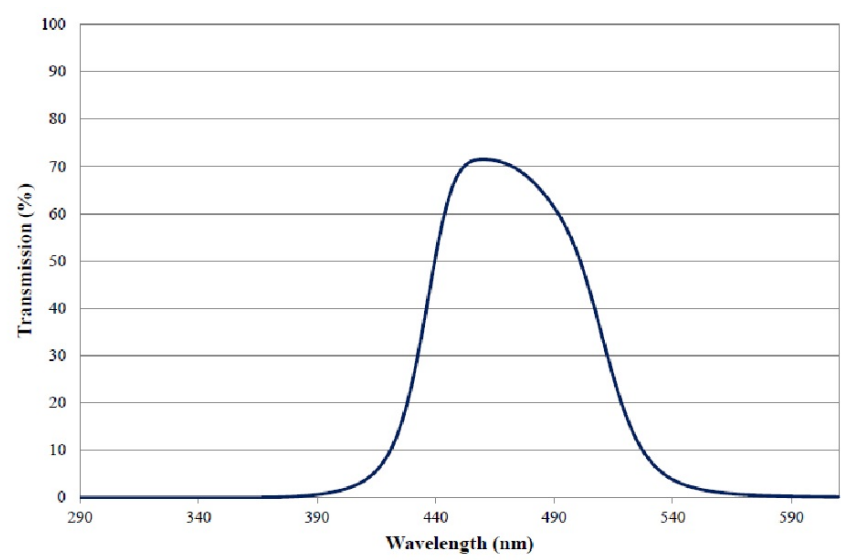

Figura 28 - Curva de transmitância do filtro passa-faixa. Fonte: <www.edmundoptics. com>

\subsection{Preparação para o estudo de caso}

Após extensa pesquisa bibliográfica sobre estudos realizados em cronobiologia e em iluminação, a partir do conteúdo abordado nas disciplinas cursadas e a partir da orientação dos professores que deram suporte a esta pesquisa, vários procedimentos ocorreram (alguns simultaneamente) para delinear o estudo de caso, descritos a seguir.

\subsubsection{Sujeitos}

Os sujeitos selecionados para este estudo foram 6 homens de 39 a 56 anos de idade e 5 mulheres de 40 a 57 anos de idade, residentes na cidade de São Paulo ${ }^{33}$. Com visão preservada, todos possuem iluminação com LEDs em suas residências. Nenhum desempenha atividades de trabalho noturno em turnos nem percorreram fusos horários 
Capítulo 5. Estudo de caso envolvendo pessoas expostas à iluminação noturna com LEDs no ambiente residencial

nas semanas que antecederam o estudo. Após entrevista inicial, onde foram observados os critérios mais importantes para a participação nesta pesquisa, o autor realizou uma visita técnica às respectivas residências, para verificar os sistemas de iluminação LED existentes, e definir os ambientes de maior permanência à noite a serem analisados. Um dos sujeitos participou deste estudo duas vezes, tendo o seu escritório residencial como o local de maior permanência à noite, com o mesmo sistema de iluminação, mas com temperaturas de cor diferentes da primeira para a segunda participação ${ }^{34}$. Um dos sujeitos ${ }^{35}$ não seguiu os procedimentos estabelecidos no protocolo, tendo seus dados desconsiderados no estudo.

\subsubsection{Preenchimento de formulário}

Os participantes foram orientados a preencher um formulário online ${ }^{36}$ contendo uma ficha cadastral (Apêndice $F$ ) e questionários, visando especialmente confirmar o atendimento aos critérios de inclusão e de exclusão, além de registrar informações que pudessem ser utilizadas para a posterior análise dos dados.

\subsubsection{Critérios de inclusão}

Selecionamos pessoas que utilizam LEDs como fontes de luz em suas residências nos ambientes de maior permanência à noite.

\subsubsection{Critérios de exclusão}

Portadores de doenças ou distúrbios não controlados, sujeitos cujo cronotipo ${ }^{37}$ tenha sido identificado como matutino extremo ou vespertino extremo, que não tenham sido submetidos a intervenções cirúrgicas e a tratamentos de manifestações agudas de doenças crônicas, usuários de drogas ilícitas, pessoas que pratiquem atividade física intensa e pessoas que não tivessem disponibilidade de estar à noite em casa durante o período de exposição à luz dos LEDs, conforme estabelecido no protocolo deste estudo.

\subsubsection{Desenvolvimento de protocolo para o estudo de caso}

O protocolo traçado para o estudo de caso teve a duração de sete dias ${ }^{38}$ e estabeleceu um período de três noites, com o uso de óculos bloqueadores de luz azul, que passaremos a nos referir como Período $B B^{39}$, seguido de um período de exposição noturna à luz dos LEDs dos ambientes verificados, que passaremos a nos referir como Período LED.

\footnotetext{
34 4000K em sua primeira participação e $3000 \mathrm{~K}$ em sua segunda participação no estudo

35 do sexo masculino

36 utilizamos o Google Docs

37 padrão de vigília-sono, verificado neste estudo pelo Questionário de Cronotipo de Horne e Ostberg

38 cada dia com início à $00 \mathrm{~h} 00 \mathrm{~m}$ até as $23 \mathrm{~h} 59 \mathrm{~m}$

39 do inglês, Blue-Blocking
} 
Capítulo 5. Estudo de caso envolvendo pessoas expostas à iluminação noturna com LEDs no ambiente residencial

As coletas de urina para a dosagem de 6-sulfatoximelatonina ocorreram na primeira noite (início do protocolo), na quarta noite (final do Período $B B$ ) e na sétima noite (final do Período LED). Os três dias que antecederam o início do protocolo foram denominados $D D$-3, $D D$-2 e $D D$-1, ao qual também passaremos a nos referir como Período Antes. Os três dias que sucederam o protocolo foram denominados $D D+1, D D+2$ e $D D+3$, ao qual também passaremos a nos referir como Período Depois. Os dados de temperatura corporal, actimetria e exposição à luz foram coletados a todo tempo.

\subsubsection{TCLE - Termo de Consentimento Livre e Esclarecido}

O Termo de Consentimento Livre e Esclarecido é um documento registrado na Comissão Nacional de Ética em Pesquisa do Ministério da Saúde, que dá ciência a cada participante de todos os procedimentos que envolvem sua participação na pesquisa. Esta pesquisa foi aprovada pelo parecer número 2.292.761 do Comitê de Ética da Escola de Artes, Ciências e Humanidades da USP (Anexo A). O TCLE (Apêndice B) foi assinado pelos participantes, pelo pesquisador e por uma testemunha após ser lido em voz alta pelo autor.

\subsection{Procedimentos adotados durante a coleta de dados}

Todas as etapas foram cumpridas com o acompanhamento diário do pesquisador, que esteve a todo tempo disponível para sanar quaisquer dúvidas dos participantes.

\subsubsection{Programação e instalação dos equipamentos para a coleta de dados}

Embora os equipamentos possuam pequenas dimensões e sua utilização dispensa cuidados especiais, a instalação inicial ocorreu sempre acompanhada pelo pesquisador, que forneceu as devidas orientações.

- o coletor de temperatura corporal iButton foi programado para efetuar uma leitura a cada 10 minutos. Foi instalado na parte anterior do punho não dominante, observando o fato de que seu sensor está localizado na parte superior do equipamento (Figura 29), conforme verificado em (HAUGHIAN, 2012), devendo esta ficar em contato com a pele. Sua fixação ocorreu com o uso de fita adesiva do tipo Micropore $^{40}$ (Figura 30 A e B). Embora este equipamento seja resistente à água, poderia ser retirado durante o banho caso os usuários assim desejassem;

- o actímetro foi programado para efetuar uma coleta a cada minuto. Foi instalado no punho não dominante, de modo a não ser posicionado sobre o coletor de temperatura. Embora este equipamento também seja resistente à água, poderia ser retirado durante o

40 fornecida pelo pesquisador 
Capítulo 5. Estudo de caso envolvendo pessoas expostas à iluminação noturna com LEDs no ambiente residencial

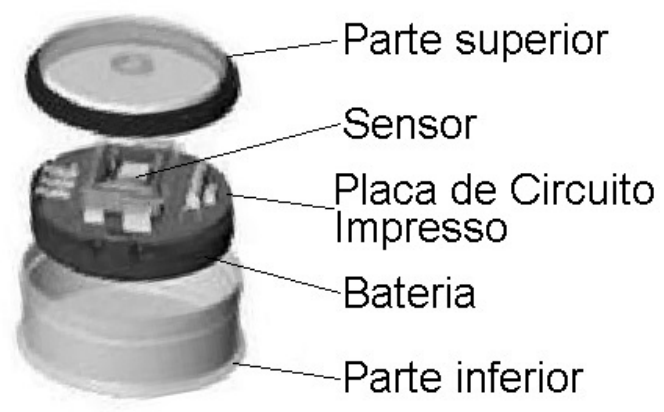

Figura 29 - Ilustração de um i-Button, revelando seus componentes internos. Fonte: Adaptado de <www.maximintegrated.com/en/products/ibutton/ibuttons/ thermochron.cfm $>$.

banho caso os usuários assim desejassem. O conjunto i-Button e Actímetro instalado pode ser visto na Figura $30 \mathrm{C}$;
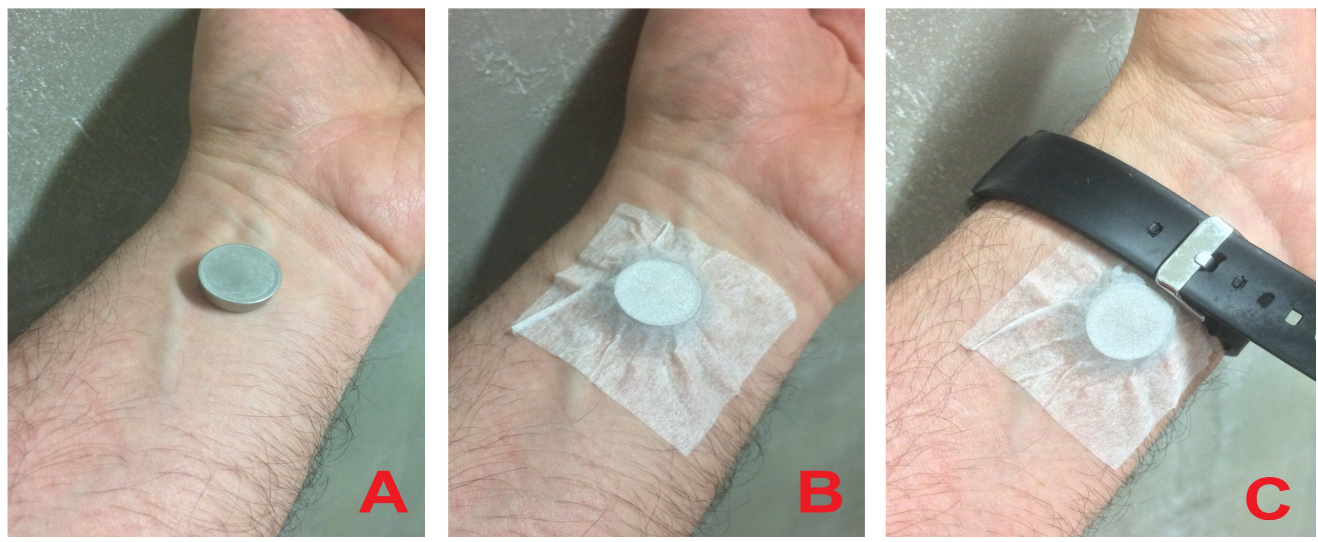

Figura 30 - A e B: Instalação do i-Button; C: i-Button e Actímetro. Fonte: Fotos do autor.

- o coletor de exposição à luz $H O B O$ foi programado para efetuar uma coleta a cada minuto. Foi instalado no pescoço como um colar, o mais próximo possível da cabeça, de modo a não ser coberto por vestimentas e de modo a não inverter sua posição (Figura 31), para que seu sensor pudesse captar a todo tempo a luz ambiente no plano vertical. Os usuários foram orientados a retirá-lo e deixá-lo ao sobre a mesa de cabeceira enquanto estivessem dormindo, com seu sensor voltado para o teto, para que houvesse o registro de eventual luz no quarto de dormir.

\subsubsection{Coleta de urina para a dosagem de 6-sulfatoximelatonina}

A coleta de urina noturna de 12 horas foi efetuada no início do protocolo (Coleta 1 - primeira noite), no final do Período $B B^{41}$ (Coleta 2 - quarta noite) e no final do Período $L E D^{42}$ (Coleta 3 - sétima noite).

$\overline{41}$ uso de óculos bloqueadores de luz azul durante 3 noites

42 exposição à luz dos LEDs durante 3 noites 


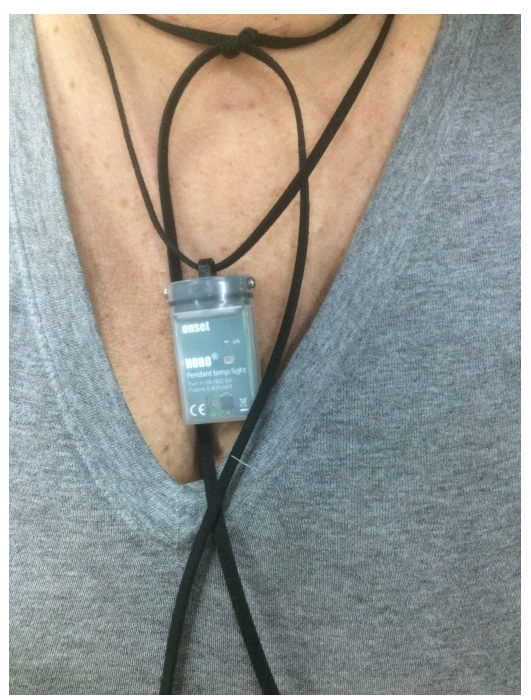

Figura 31 - Instalação do HOBO. Fonte: Foto do autor.

Nos três dias em que houve a coleta de urina, recomendamos que os sujeitos evitassem cafeína (café, refrigerantes que contenham cafeína, etc.), exercício físico e bebidas alcoólicas. Os procedimentos para a coleta de urina foram os seguintes:

- às 19h00m: Esvaziar a bexiga, desprezando esta urina;

- a partir das 19h00m: Coletar toda a urina noturna no frasco grande de $2000 \mathrm{ml}$;

- 07h00 do dia seguinte: Efetuar a última coleta de urina no frasco grande e fazer a leitura do volume total coletado ${ }^{43}(\mathrm{em} \mathrm{ml})$;

- anotar no frasco pequeno, com tampa vermelha, o número da coleta (1, 2 ou 3) e o volume total coletado (em $\mathrm{ml}$ ). Utilizar para tal a caneta especial fornecida pelo pesquisador;

- transferir para o frasco pequeno uma amostra de $10 \mathrm{ml}$ da urina total coletada ${ }^{44}$ (em $\mathrm{ml}$ ). Fechar bem a tampa e colocar este frasco imediatamente no congelador;

- descartar o frasco grande;

- congelar o frasco pequeno, com tampa vermelha, contendo a amostra de número 1, 2 ou 3.

Todos os coletores de urina (frascos grandes de $2000 \mathrm{ml}$ e frascos pequenos de $50 \mathrm{ml}$ ) foram gentilmente cedidos pelo Instituto de Ciências Biomédicas da USP para esta pesquisa.

Ao final da participação de cada sujeito, o pesquisador coletou todas as amostras de urina, que foram posteriormente enviadas para análise.

\footnotetext{
43 o frasco grande possui marcações que indicam o volume de seu conteúdo

44 o frasco pequeno possui marcações que indicam o volume de seu conteúdo
} 
Capítulo 5. Estudo de caso envolvendo pessoas expostas à iluminação noturna com LEDs no ambiente residencial

\subsubsection{Levantamento fotométrico e coleta de imagens fotográficas}

Durante visita à residência de cada sujeito, o pesquisador efetuou o levantamento fotométrico dos ambientes de maior permanência à noite.

As iluminâncias médias aferidas e as características dos sistemas de iluminação podem ser vistas na Tabela 4. As luminâncias máximas (verificadas com o aplicativo Aftab Luminance) aparecem na Tabela 5.

Tabela 4 - Levantamento fotométrico dos ambientes residenciais envolvidos neste estudo (Iluminâncias e caraterísticas dos sistemas).

\begin{tabular}{|r|c|c|c|}
\hline Ambiente & Iluminância Média (lux) & Temperatura de cor (K) & Sistemas de Iluminação \\
\hline 1 & 149 & 3000 e 4000 & geral direta difusa / de destaque \\
\hline 2 & 226 & 5000 e 6500 & geral direta \\
\hline 3 & 232 & 4000 & geral direta difusa \\
\hline 4 & 47 & 3000 & geral indireta \\
\hline 5 & 83 & 2700 e 3000 & geral direta difusa / indireta \\
\hline 6 & 158 & 5000 & geral direta \\
\hline 7 & 228 & 3000 & geral direta difusa \\
\hline 8 & 90 & 3000 e 5000 & geral indireta / de destaque \\
\hline 9 & 150 & 3000 & geral indireta / decorativa \\
\hline 10 & 263 & 3000 & \\
\hline
\end{tabular}

Tabela 5 - Levantamento fotométrico dos ambientes residenciais envolvidos neste estudo (Luminâncias).

\begin{tabular}{|r|c|}
\hline Ambiente & Luminância Máxima $\left(\mathrm{cd} / \mathrm{m}^{\mathbf{2}}\right)$ \\
\hline 1 & 3.85 \\
\hline 2 & 9.74 \\
\hline 3 & 8.52 \\
\hline 4 & 1 e $3.58(2$ ambientes $)$ \\
\hline 5 & 1.22 \\
\hline 6 & 11.47 \\
\hline 7 & 8.17 \\
\hline 8 & 4.97 \\
\hline 9 & 3.47 \\
\hline 10 & 1.54 \\
\hline
\end{tabular}

O aplicativo Aftab Luminance também nos permitiu a coleta de imagens fotográficas para verificar as luminâncias dos ambientes a partir da posição do observador. Estas

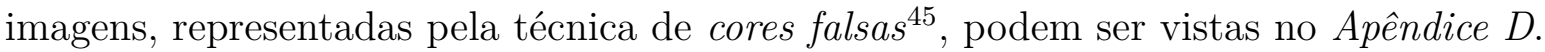
45 os níveis de luminância são representados por cores 
Capítulo 5. Estudo de caso envolvendo pessoas expostas à iluminação noturna com LEDs no ambiente residencial

O levantamento de imagens fotográficas com o uso do filtro passa-faixa, com o objetivo de inspecionar visualmente a quantidade de luz azul presente nos ambientes. pode ser visto no Apêndice E.

\subsubsection{Protocolo completo}

As instruções recebidas pelos sujeitos do estudo de caso se encontram no Apêndice $A$. Durante o cumprimento do protocolo, o pesquisador fez contatos diários por meio de aplicativo de mensagens eletrônicas para reiterar os procedimentos do dia, e permaneceu a todo tempo disponível, também por telefone, para o esclarecimento de eventuais dúvidas. O protocolo completo deste estudo é descrito a seguir:

- Instalação dos equipamentos de coleta de dados 3 dias antes do início do protocolo para o estudo, o que possibilitou um período de adaptação ao uso dos equipamentos e a coleta dos dados $D D$-3, $D D$-2 e $D D-1^{46}$;

- Dia 1 - Início do Protocolo, com a coleta dos dados $D D-1$ e à noite a coleta da primeira amostra de urina de 12 horas para a dosagem de 6-sulfatoximelatonina, cujos procedimentos já foram descritos. Esta amostra revelará a carga total de 6-sulfatoximelatonina excretada antes de ocorrerem as intervenções de exposição à luz;

- Dias 2, 3 e 4 - Período de uso dos óculos bloqueadores de luz azul à noite e coleta dos dados $B B 1, B B 2$ e $B B 3$, ocorrendo na noite do dia 4 a coleta da segunda amostra de urina de 12 horas para a dosagem de 6-sulfatoximelatonina. Esta amostra revelará a carga total de 6-sulfatoximelatonina excretada após o sujeito permanecer três noites sem exposição à luz noturna ${ }^{47}$;

- Dias 5, 6 e 7 - Período de exposição à luz dos LEDs dos ambientes estudados e coleta dos dados $L E D 1, L E D 2$ e $L E D 3$, ocorrendo na noite do dia 7 a coleta da terceira amostra de urina de 12 horas para a dosagem de 6-sulfatoximelatonina. Esta amostra revelará a carga total de 6-sulfatoximelatonina excretada após o sujeito permanecer três noites exposto à luz noturna dos LEDs.

Após o cumprimento do protocolo, os sujeitos permaneceram com os equipamentos durante mais três dias, o que possibilitou a coleta do dados $D D+1, D D+2$ e $D D+3^{48}$.

\subsection{Preparação dos dados para análise}

Os dados coletados pelos equipamentos foram transferidos e armazenados em computador ao longo do estudo e tabelados em planilha Microsoft Excel, na medida em

\footnotetext{
46 dados coletados durante os três dias que antecederam o protocolo desta pesquisa

47 luz capaz de estimular a fotorrecepção circadiana

48 dados coletados durante os três dias que sucederam o protocolo desta pesquisa
} 
Capítulo 5. Estudo de caso envolvendo pessoas expostas à iluminação noturna com LEDs no ambiente residencial

que se encontravam disponíveis. Foram, em seguida, separados de acordo com os períodos a serem considerados na análise ${ }^{49}$, gerando para cada sujeito arquivos individuais com pastas diferentes para os dados de actimetria, de temperatura corporal e de exposição à luz.

Os dados da análise de 6-sulfatoximelatonina ${ }^{50}$ enviados pelo Laboratório de Fisiologia e Biofísica do Instituto de Ciências Biomédicas da USP foram tabelados, por sujeito e pelos períodos de coleta ${ }^{51}$.

Os questionários foram interpretados e seus resultados e igualmente tabelados.

A série temporal de temperatura corporal foi tratada de modo a eliminar outliers ${ }^{52}$, conforme descrito por (HOAGLIN; IGLEWICZ; TUKEY, 1986).

\subsubsection{Análise estatística}

Os softwares utilizados para as análises estatísticas foram o $S P S S^{53}$ para os testes de Kolmogorov-Smirnov (normalidade), variância e o teste de Wilcoxon Pareado ${ }^{54}$, o El Temps para análise de Rayleigh e o ActStudio para análise de Cosinor, descrito por (HALBERG; TONG; JOHNSON, 1967).

\subsection{Análise dos resultados}

O protocolo para este estudo estabeleceu dois períodos distintos de exposição à luz noturna. O primeiro composto por três noites em que os sujeitos utilizavam óculos para filtrar a luz, eliminando sua porção azul ${ }^{55}$; e o segundo composto por três noites em que os sujeitos eram expostos à luz dos LEDs ${ }^{56}$.

As variáveis foram analisadas de modo a comparar seu comportamento do Período Antes com eventuais alterações observadas ao final do Período BB, e do Período $B B$ com eventuais alterações observadas ao final do Período LED.

\subsubsection{6-Sulfatoximelatonina}

A relação entre luz noturna e a supressão pineal do hormônio melatonina foi estabelecida há décadas. Investigamos neste estudo se a luz emitida por LEDs, especialmente em razão de sua composição espectral, já mencionada, com as intensidades e configurações

\footnotetext{
49 Antes, BB, LED e Depois)

50 três coletas para cada sujeito

51 Antes do protocolo, após período BB e após o período LED

52 valores atípicos resultantes, por exemplo, da retirada do equipamento

53 Statistical Package for Social Science

54 para comparar duas amostras de dados

55 período $\mathrm{BB}$

56 período LED
} 
Capítulo 5. Estudo de caso envolvendo pessoas expostas à iluminação noturna com LEDs no ambiente residencial

utilizadas nos projetos luminotécnicos residenciais, poderia causar alterações na síntese de melatonina, o que foi verificado por meio da comparação da carga excretada, na urina, de 6-sulfatoximelatonina no final do Período BB, com a carga excretada no final do Período $L E D$.

Dos 10 sujeitos analisados, 7 apresentaram redução de 6-sulfatoximelatonina entre o Período BB e o Período LED, conforme ilustrado na Figura 32, indicando que houve impacto - causado pela exposição noturna à iluminação com LEDs - na síntese de melatonina para estes sujeitos. Podemos também observar um acentuado aumento da carga excretada entre a aferição inicial (Antes) e o Período BB, indicando que estes sujeitos provavelmente já apresentavam, antes deste estudo, alteração deste hormônio como consequência da exposição à luz noturna.

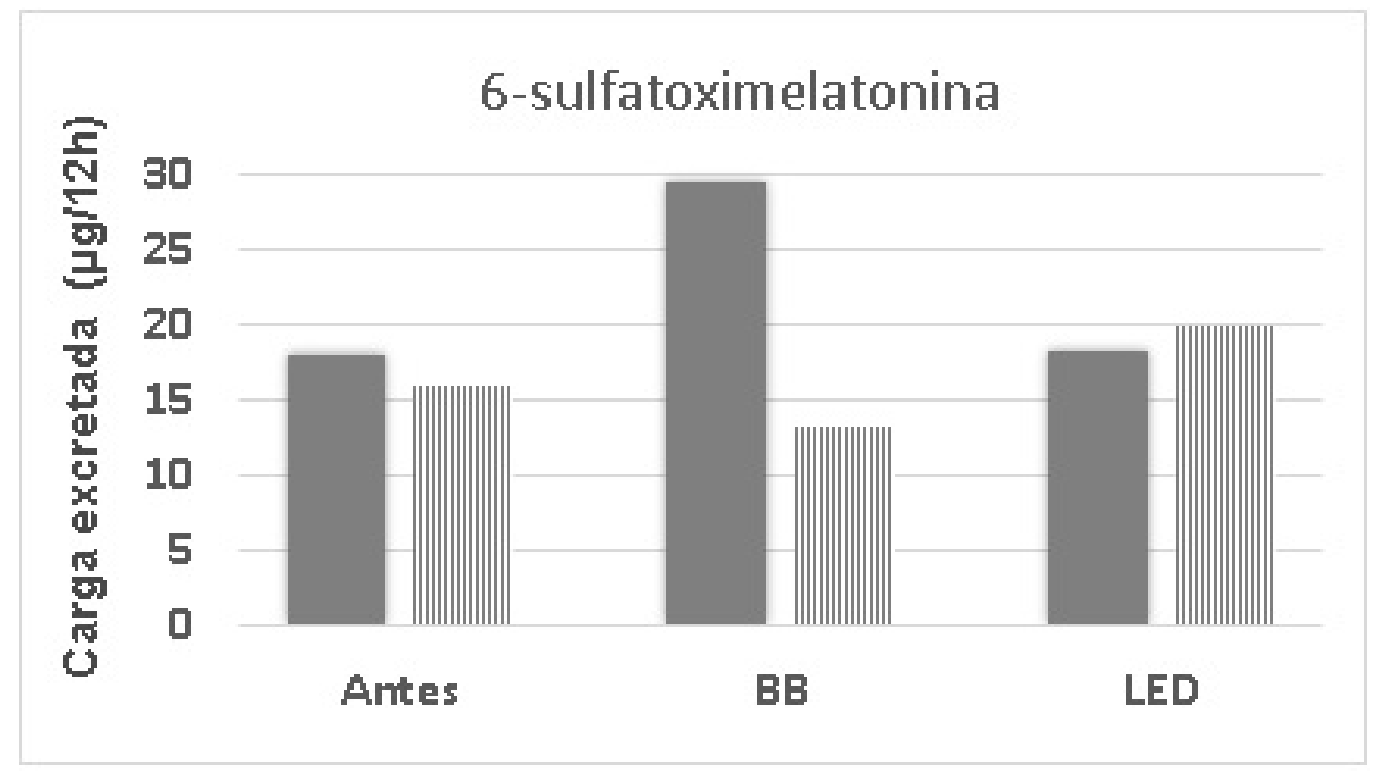

Figura 32 - Impacto da luz noturna de LEDs sobre a síntese de melatonina. Os blocos com preenchimento sólido se referem aos 7 sujeitos que apresentaram redução hormonal entre o Período BB e o Período LED. Os blocos listrados se referem aos 3 sujeitos em que esta relação não foi observada.

Nos 3 sujeitos em que esta resposta não foi observada, é possível verificar que houve oscilações do hormônio, porém com níveis sempre reduzidos em relação ao grupo anterior.

Cabe aqui ressaltar que a significância estatística do grupo que apresentou resposta hormonal à modulação de luz foi $p<0,05$ (Tabela 6), ao se comparar os dados Antes-BB e os dados $B B-L E D$, indicando uma forte relação entre o estímulo (luz) e a resposta hormonal (melatonina).

No Apêndice D é possível verificar a análise fotográfica de luminâncias nos ambientes cujos usuários apresentaram redução hormonal (Ambientes 1 a 7) e nos ambientes cujos usuários não apresentaram este efeito (Ambientes 8 a 10). 
Capítulo 5. Estudo de caso envolvendo pessoas expostas à iluminação noturna com LEDs no ambiente residencial

Tabela 6 - Significâncias estatísticas entre os pares de dados, calculadas pelo teste de Wilcoxon Pareado para o grupo em que houve resposta hormonal à luz noturna.

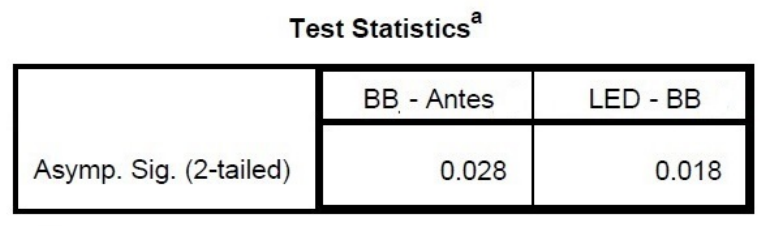

a. Wilcoxon Matched Pairs Test

No Apêndice E é possível verificar a análise fotográfica que mostra a intensidade de luz azul nos ambientes cujos usuários apresentaram redução hormonal (Ambientes 1 a 7) e dos ambientes cujos usuários não apresentaram este efeito (Ambientes 8 a 10).

\subsubsection{Temperatura corporal}

A síntese pineal do hormônio Melatonina pode ser suprimida de modo agudo, sofrer avanço de fase ou atraso de fase por um único pulso de luz (KHALSA et al., 2003). O ritmo de temperatura corporal, contudo, pela maior robustez de seus mecanismos de regulação, pode apresentar alterações em resposta à luz apenas 3 dias após período de exposição (KHALSA et al., 2000), razão pela qual consideramos, para analisar a acrofase ${ }^{57}$, a amplitude e o MESOR da temperatura corporal periférica, a observação dos dois dias (ou ciclos) após o final de cada período. Ou seja, eventuais alterações do ritmo de temperatura corporal provocadas pelo Período $B B$ foram verificadas nos dois primeiros dias do Período $L E D$, e eventuais alterações do ritmo de temperatura corporal provocadas pelo Período $L E D$ foram verificadas nos dois primeiros dias do Período Depois. O terceiro dia após o término de cada período foi descartado desta análise para evitar possível mascaramento causado pela transição entre dois períodos. Um dos participantes do estudo não coletou os dados após o Período $L E D$, não tendo sido possível verificar o impacto deste período sobre seu ritmo de temperatura corporal.

A análise de Cosinor, proposta por (HALBERG; TONG; JOHNSON, 1967), foi utilizada para calcular MESOR, Amplitude e Acrofase da temperatura corporal, sendo que esta última tem a capacidade de revelar se houve deslocamento de fase entre os períodos. Para estes cálculos, utilizamos o software ActStudio, que ajusta os dados temporais de temperatura para a curva sinusoidal ${ }^{58}$ de 24 horas, extraindo o ritmo principal da temperatura corporal (Figura 33).

A amplitude e a acrofase da temperatura corporal podem ser expressas por meio

\footnotetext{
57 que corresponde à batifase da temperatura central

58 ou senoidal
} 
Capítulo 5. Estudo de caso envolvendo pessoas expostas à iluminação noturna com LEDs no ambiente residencial

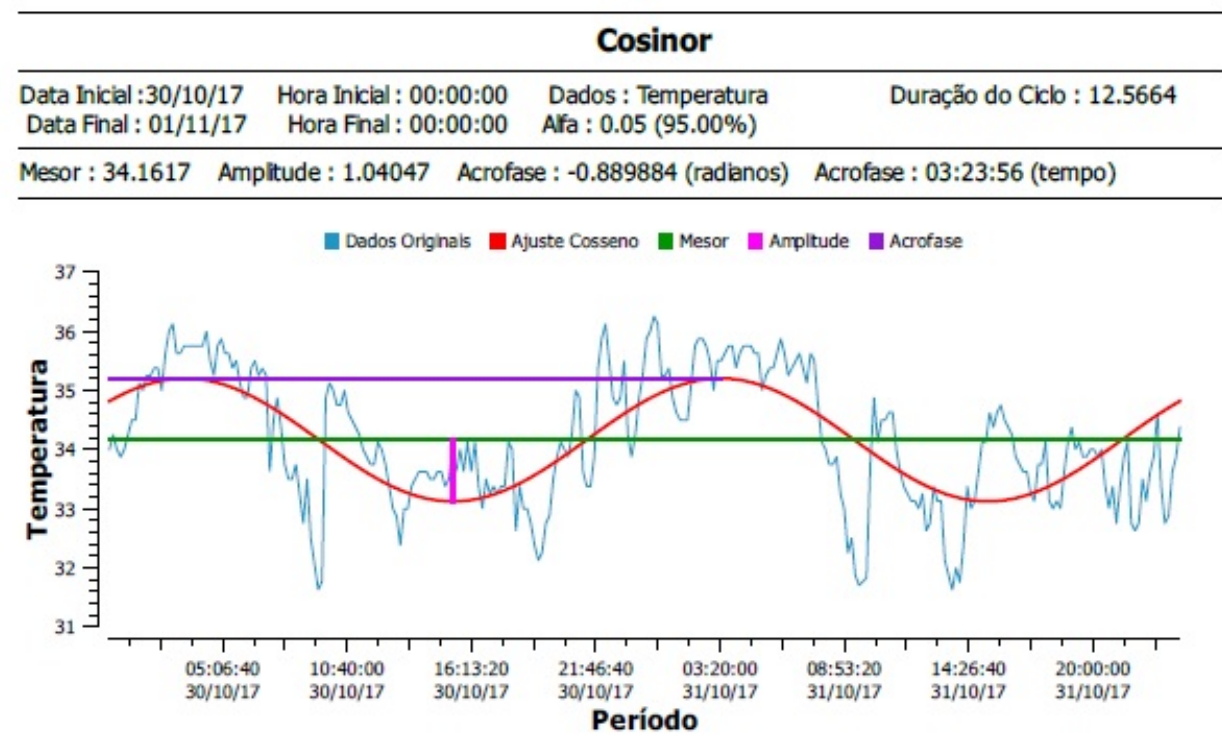

Figura 33 - Exemplo da representação temporal dos dados de dois dias da temperatura corporal, extraída do software ActStudio, com os cálculos de MESOR, Amplitude e Acrofase para o período de 2 dias.

de vetores no diagrama polar, em que uma escala circular de $360^{\circ}$ representa as 24 horas do dia. Em nossa pesquisa, utilizamos o diagrama polar para representar a acrofase média de cada sujeito para cada período do estudo, conforme o exemplo da Figura 34.
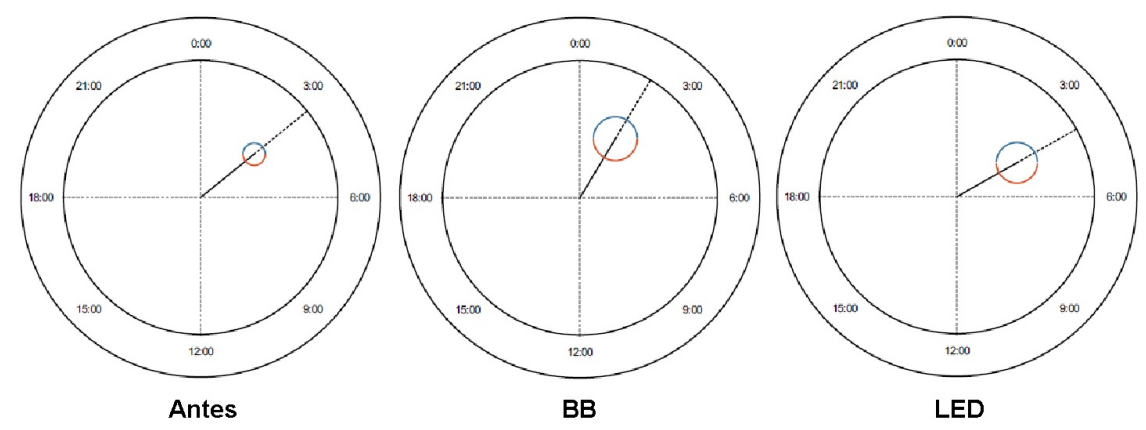

Figura 34 - Exemplo do Diagrama Polar da análise de Cosinor. Para este sujeito, a Acrofase média ocorreu às $03 \mathrm{~h} 23 \mathrm{~m}$ no Período Antes, às $02 \mathrm{~h} 03 \mathrm{~m}$ no Período $B B$ e às $04 \mathrm{~h} 54 \mathrm{~m}$ no Período $L E D$

A análise de Cosinor de todos os sujeitos pode ser vista no Apêndice $C$. 
Capítulo 5. Estudo de caso envolvendo pessoas expostas à iluminação noturna com LEDs no ambiente residencial

\subsubsection{Acrofase}

Dos 9 sujeitos analisados, 7 apresentaram deslocamento de fase do ritmo de temperatura corporal do Período Antes para o Período BB e do Período BB para o Período LED $(p<0,05)$, conforme ilustrado na Figura 35, sendo este último deslocamento de fase provavelmente causado pela exposição noturna à iluminação residencial com LEDs.

Do Período Antes para o Período $B B$ houve um avanço de fase ${ }^{59}$, em média, de 1h10m. Do Período BB para o Período $L E D$ houve um atraso de fase ${ }^{60}$, em média, de $1 \mathrm{~h} 57 \mathrm{~m}$.

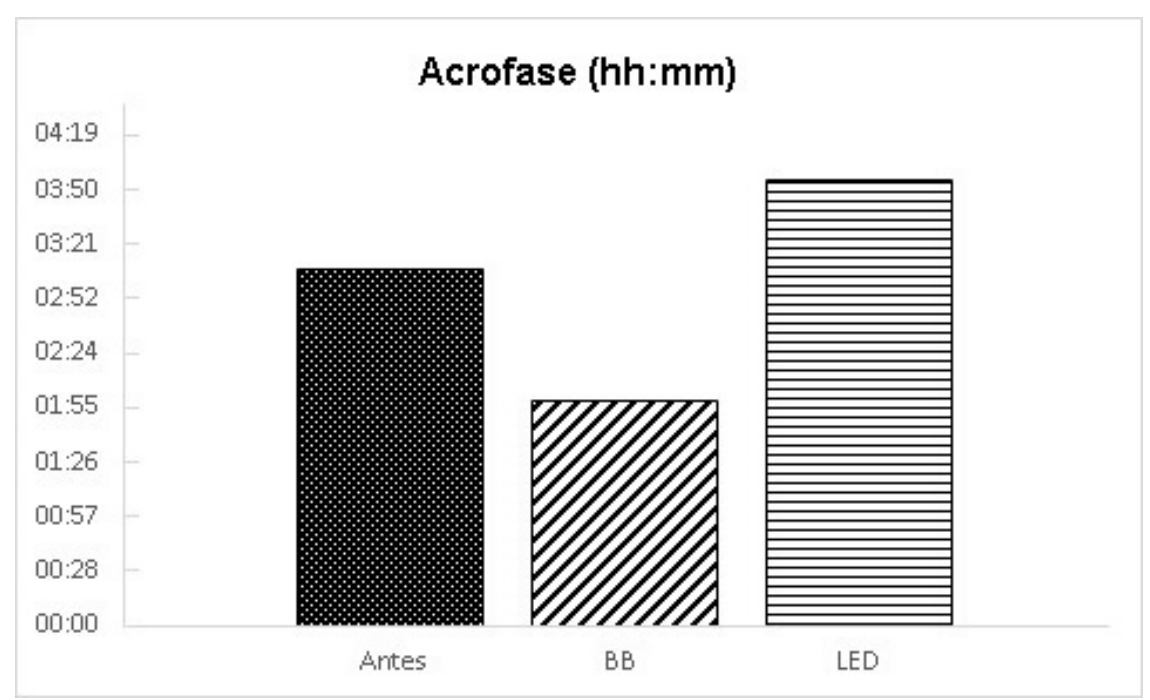

Figura 35 - Impacto da luz noturna de LEDs sobre o ritmo de temperatura corporal. No Período Antes a Acrofase média ocorreu às $03 \mathrm{~h} 08 \mathrm{~m}$, no Período $B B$ às $01 \mathrm{~h} 58 \mathrm{~m}$ e no Período $L E D$ às $03 \mathrm{~h} 55 \mathrm{~m}$.

\subsubsection{Amplitude e Mesor}

Estas variáveis apresentaram alterações ao longo do estudo, mas para a totalidade dos sujeitos não observamos valores significativos que caracterizassem uma resposta robusta às variações do padrão de exposição à luz. Contudo, ao cruzar todos os dados desta pesquisa, algumas alterações individuais de destacaram do conjunto, o que abordaremos no Capítulo 6.

\subsubsection{Actimetria}

Embora a actimetria necessite de uma longa série temporal para avaliar o ritmo vigília-sono, os dados coletados em nossa pesquisa também foram utilizados para comparar alterações entre o Período BB e o Período LED.

\footnotetext{
59 a acrofase ocorreu mais cedo

60 a acrofase ocorreu mais tarde
} 
Capítulo 5. Estudo de caso envolvendo pessoas expostas à iluminação noturna com LEDs no ambiente residencial

Não foram registradas diferenças significativas nas médias de $I V, I S, L 5$ e $M 10$ para o conjunto formado pela totalidade dos sujeitos de nosso estudo. Contudo, ao observar estas mesmas variáveis para o grupo de sujeitos que apresentou redução da síntese de Melatonina ${ }^{61}$ como resposta à iluminação artificial com LEDs, verificamos que o L5 apresentou um atraso de 15 minutos, tendo início às $00 \mathrm{~h} 26 \mathrm{~m}(p<0,05)$ no Período $B B$ e às 00h41m $(p<0,05)$ no Período LED.

61 verificada pela dosagem de 6 -Sulfatoximelatonina 


\section{Discussão}

A análise dos resultados, a observação das relações existentes entre as variáveis e o cruzamento dos dados produzidos pelo estudo de caso nos conduziram aos pontos descritos a seguir:

- Conforme vimos, a dosagem de 6-sulfatoximelatonina revelou que 7 dos 10 sujeitos do estudo de caso apresentaram redução do hormônio melatonina no período em que foram expostos à iluminação artificial dos LEDs de suas residências ${ }^{1}$. Examinando os dados dos 3 sujeitos em que este efeito não ocorreu ${ }^{2}$, observamos o seguinte:

- Estes sujeitos apresentaram maior exposição à luz natural ${ }^{3}$, com média diária acima de 2000 lux das 07h00 às 19h00, sendo que um deles apresentou média diária acima de 5000 lux. Esta maior exposição faz com que haja uma variação robusta de incidência de luz na retina, entre o período diurno e o período noturno, o que poderia justificar a maior resistência destes sujeitos aos impactos da luz noturna. Este dado pode ser importante para estudos futuros, que investiguem diferenças de sensibilidade do sistema não visual circadiano a diferentes padrões de exposição à luz;

- Dois destes três sujeitos ${ }^{4}$ possuem em seus ambientes sistemas de iluminação geral indireta e sistemas para iluminação de destaque, ambos com as fontes de luz inseridas na arquitetura, evitando sua visualização, o que reduz os níveis de Luminância para os usuários, o que também poderia explicar o fato de não terem apresentado redução hormonal na presença da luz noturna dos LEDs;

- O terceiro sujeito ${ }^{5}$ também foi o que apresentou maior amplitude de temperatura corporal, possivelmente em consequência da maior exposição diurna à luz. Pessoas com maior amplitude de temperatura corporal se adaptam mais lentamente às mudanças ambientais, dificultando o arrastamento de seus ritmos biológicos em situações, por exemplo, de mudanças de fuso horário (JANSEN et al., 2007, p. 178).

- Observando o resultado dos questionários, dos 7 sujeitos que apresentaram redução do hormônio melatonina no período em que foram expostos à iluminação artificial dos LEDs de suas residências:

1 ambientes 1 a 7 da Tabela 4 e da Tabela 5

2 ambientes 8 a 10 da Tabela 4 e da Tabela 5

3 níveis elevados de iluminância no plano vertical durante a maior parte do dia, aferidos de 1 em 1 minuto

4 ambientes 9 e 10 da Tabela 4 e da Tabela 5

5 aquele que apresentou a maior exposição à luz natural 
- 3 sujeitos apresentaram o resultado "Sofrimento Mental" no questionário de avaliação de transtorno psiquiátrico (SRQ-20), indicando a presença de distúrbios neurocomportamentais como insônia, fadiga, irritabilidade, esquecimento ou dificuldade de concentração;

- 2 sujeitos apresentaram o resultado "Distúrbio do Sono" no questionário que avalia a qualidade do sono (PSQI); e

- 6 sujeitos apresentaram o resultado "Distúrbio" ou "Sonolência Excessiva" na escala de Sonolência diurna de Epworth.

Todos os distúrbios acima, conforme amplamente relatado na literatura, podem ter origem na dessincronização circadiana.

- Em relação à acrofase da temperatura corporal, do período que antecedeu o protocolo de nossa pesquisa (Período Antes) para o período em que os sujeitos foram expostos à iluminação artificial dos LEDs de suas residências (Período LED), houve um atraso de fase médio de 47 minutos $^{6}$, indicando que, provavelmente, a exposição de três noites seguidas à luz dos $\operatorname{LEDs}^{7}$ causou no ritmo de temperatura corporal dos sujeitos um impacto maior que a iluminação noturna a que os sujeitos já eram submetidos em seu dia-a-dia fora de casa.

- A observação contínua dos dados produzidos por este estudo conduziu o pesquisador a estabelecer algumas relações entre a exposição à luz noturna dos LEDs e as variáveis da temperatura corporal periférica ${ }^{8}$ :

- quanto mais luz noturna, mais tarde ocorre a acrofase;

- quanto mais luz noturna, menor a amplitude;

- quanto mais luz noturna, maior o MESOR.

- O atraso de 15 minutos, revelado pela actimetria na variável $L 5$, indicando que o período de 5 horas de menor atividade motora ocorreu mais tarde no Período LED, corrobora com os achados descritos nas demais análises de nossos dados ${ }^{9}$, reiterando a ideia de que a iluminação noturna com LEDs pode provocar atraso de fase ou desorganização temporal dos ritmos biológicos.

- Dos 10 sujeitos, 4 reportaram aumento de sonolência noturna durante o Período BB (período com o uso de óculos bloqueadores de luz azul à noite), sendo que um deles afirmou ter conseguido, neste período, suspender o uso de medicamento indutor de sono, e outros dois reportaram ter apresentado sono menos fragmentado ao longo da noite, possivelmente como consequência do aumento da síntese de melatonina, verificado na

média para todos os sujeitos

7 Período LED

8 estas relações foram observados para este estudo, necessitando ser validadas em estudos posteriores

9 6-sulfatoximelatonina e temperatura corporal 
pesquisa. Contudo, 3 sujeitos, ao tentar desempenhar tarefas visuais como leitura, o que não era recomendado, reportaram ter sentido enjoo neste mesmo período.

\subsection{Limitações deste estudo}

As principais limitações identificadas pelo autor ocorreram principalmente pela novidade do tema e pela velocidade com que novos conhecimentos tem sido produzidos no campo da iluminação artificial.

- A dosagem de 6-sulfatoximelatonina revela alterações do volume de melatonina em resposta à luz noturna, mas não nos informa se houve avanço ou atraso de fase circadiana. Para tal, seria necessário saber a hora do início da sua síntese, ou $\mathrm{DLMO}^{10}$, verificado por meio de dosagens sucessivas de melatonina salivar, procedimento que possui custo elevado;

- A quantificação da luz artificial dos ambientes ocorreu por meio do levantamento fotométrico de Iluminância e de Luminância que, por definição, são grandezas que se referem ao sistema visual. A inexistência de uma grandeza que quantifique a luz para a regulação circadiana, faz com que o ideal seja aferir a energia que atinge os olhos ${ }^{11}$ para cada comprimento de onda, possível com a utilização do espectroradiômetro, equipamento de custo igualmente bastante elevado;

- A opção pela pesquisa de campo em vez de pesquisa laboratorial também trouxe limitações, pelo fato de não haver como controlar algumas importantes variáveis, como intensidades de luz, horários de repouso e de despertar, temperatura ambiente e horários de refeições;

- Por fim, o fato de as variáveis biológicas sofrerem constantes adaptações em sua interação com o meio, tornaram mais difícil o processo de análise e interpretação dos dados coletados.

\subsection{Recomendações para o projeto luminotécnico residencial com LEDS}

Os resultados obtidos no estudo de caso e seu cruzamento com as características dos respectivos sistemas de iluminação instalados nos conduziram, ao menos em caráter preliminar, à formulação de recomendações a serem utilizadas como referência para o projeto luminotécnico residencial que utiliza LEDs como fonte de luz, apresentadas abaixo.

\footnotetext{
10 Dim Light Melatonin Onset

11 em $\mu \mathrm{W} / \mathrm{cm}^{2}$
} 
Notamos que, para o sistema não visual circadiano, a avaliação dos níveis de Luminância é mais importante que dos níveis de Iluminância, pois houve casos em que estes eram extremamente baixos, mas aqueles projetavam nos usuários intensidades luminosas elevadas, causando impacto nas variáveis biológicas aqui aferidas.

- Utilizar LEDs com baixas temperaturas de cor $^{12}$ nos ambientes da área social e da área íntima;

- Utilizar LEDs com médias ou elevadas temperaturas de cor $^{13}$ nos ambientes da área funcional de utilização diurna;

- Utilizar sistemas que possibilitem a troca de temperatura de cor ${ }^{14}$ nos ambientes em que haja o desempenho de tarefas visuais diurnas e noturnas, como cozinhas, lavanderias e escritórios;

- Priorizar o uso de sistemas de iluminação indireta e/ou difusa;

- Evitar fontes de luz aparentes;

- Utilizar sistemas eletrônicos para controle dos níveis de luz;

- Inserir luz noturna (para evitar o acendimento de luzes ao longo da noite) que não contenha azul em sua composição espectral ${ }^{15}$;

- Verificar, para cada projeto residencial, os níveis de Luminância projetados pelos sistemas de iluminação nos olhos dos usuários, especialmente nos ambientes de maior permanência à noite.

\footnotetext{
2 abaixo de $3000 \mathrm{~K}$

13 acima de $4000 \mathrm{~K}$

14 tunable

15 ex: âmbar
} 


\section{Considerações finais}

A iluminação artificial tem sido cada vez mais utilizada em nossa sociedade, mesmo durante o dia, pois permanecemos grande parte de nosso tempo de vigília em ambientes com pouca ou nenhuma incidência de luz natural. À noite, a exposição à luz artificial rica em azul tem aumentado, por causa da disseminação dos LEDs para iluminação arquitetônica e para uso em equipamentos eletrônicos, como telas de computadores, TVs e tablets (TOSINI; FERGUSON; TSUBOTA, 2016).

Outra importante mudança se dá pelo fato de que a leitura em papel ocorria por meio de luz refletida. Hoje a leitura ocorre pela emissão de luz direta, proveniente dos equipamentos. Pesquisadores mostraram que a supressão de melatonina noturna após 1 hora de utilização de equipamentos com displays luminosos foi, em média, 3\% (WOOD et al., 2013)

Nosso conhecimento sobre o sistema circadiano humano é incompleto (BELLIA; SERACENI, 2014). As respostas não visuais à luz de diferentes espectros tem sido objeto de estudo, como uma pesquisa (PLITNICK et al., 2010) demonstrando que luz vermelha à noite induz o estado de alerta sem impactar a síntese endócrina de melatonina.

Mais recentemente, descobriu-se que cones e bastonetes também contribuem para o sistema não visual, especialmente em baixas intensidades de luz e para exposições de curta duração. Portanto, a sensibilidade espectral dessas respostas à luz é dinâmica, com propriedades que se modificam dependendo da intensidade, duração e histórico de exposição (ANDERSEN; GOCHENOUR; LOCKEY, 2013).

O conhecimento científico atual a respeito do impacto da luz sobre os ritmos circadianos deve ser considerado para o projeto luminotécnico, pois evitá-lo nos conduzirá ao erro de omissão (REA; FIGUEIRO, 2016).

Segundo (REA, 2016),

temos a obrigação profissional, se não moral, de oferecer iluminação que promova a regulação circadiana.

\subsection{Conclusão}

A ciência já estabeleceu por meio de inúmeros estudos que a luz noturna produz efeitos deletérios nos seres. Em humanos, pode provocar ou contribuir para o surgimento de vários distúrbios, já mencionados nos Capítulos 2 e 3. Várias pesquisas realizadas em laboratório comprovaram que a iluminação residencial causa atraso de fase da síntese de melatonina, mas até recentemente apenas um estudo de campo (BURGESS; MOLINA, 
2014) foi realizado ${ }^{1}$, sem contudo informar as fontes de luz utilizadas, nem estabelecer relações dos resultados observados com as características dos sistemas de iluminação artificial das residências.

Nossa pesquisa foi a primeira a realizar um estudo de campo dedicado a examinar o impacto dos LEDs utilizados para iluminação residencial, reportando, igualmente pela primeira vez, alterações na carga da melatonina sintetizada e no ritmo de temperatura corporal como consequência da iluminação arquitetônica que utiliza LEDs como fontes de luz.

No que se refere às normas técnicas, os achados desta pesquisa reiteram a necessidade urgente de atualizá-las, para que passem a considerar o sistema não visual circadiano e contribuam para a promoção de ambientes mais saudáveis.

Do mesmo modo, é necessário que o Lighting Designer, arquiteto ou não, além de interagir com a arquitetura, dar expressividade e significado aos ambientes, atender a critérios técnicos, funcionais e normativos, além de buscar eficiência energética, se familiarize com o tema "Luz e Saúde", e considere em seus projetos o sistema não visual e as tarefas a serem desempenhadas em cada ambiente em particular, para escolher a iluminação mais adequada de acordo com cada hora do dia.

\subsection{Projeção para pesquisas futuras}

A iluminação arquitetônica tem apresentado constante evolução conceitual. Antes, iluminávamos para ver. Em seguida, as normas técnicas inseriram ao projeto luminotécnico critérios $^{2}$ de desempenho e eficiência energética, simultaneamente ao aumento das exigências estéticas dos usuários. A descoberta do sistema não visual circadiano e de sua sensibilidade espectral à luz trouxe a era Human-Centric ${ }^{3}$, em que a iluminação deve ser voltada para o bem-estar e para a saúde dos usuários. Todas estas mudanças foram consequência de pesquisas científico-acadêmicas. Quando falamos em composição espectral das fontes de luz, muito há que se pesquisar, pois a exposição a cada intensidade de cada comprimento de onda pode ter efeitos ainda desconhecidos.

A relação dose-resposta também precisa ser investigada, pois em nosso estudo verificamos a que a exposição à luz diurna pode ter influenciado as variáveis observadas à noite.

As diversas áreas do saber foram assim divididas para facilitar seu estudo. Contudo, o mundo globalizado trouxe a velocidade da informação e, consequentemente, a interdisciplinaridade, razão pela qual é necessário trazer, por exemplo, a cronobiologia para a

\footnotetext{
examinando o DLMO dos sujeitos

quantitativos e qualitativos

voltada para o ser humano
} 
arquitetura e promover, cada vez mais, estudos interdisciplinares como este. O estudo do tema Luz e Saúde necessita constante busca de conhecimentos da biologia, da medicina, da fisiologia, da engenharia, da física, da psicologia, da saúde pública e, evidentemente, da arquitetura.

O ser humano vive em constante interação com o meio. Precisamos conhecer melhor estes processos para tornar o ambiente construído cada vez mais saudável. 


\section{Referências}

ABNT. NBR 5413 - Iluminâncias de interiores. [S.l.], 1992. Citado na página 52.

ABNT. NBR ISO/CIE 8995-1 - Iluminação de ambientes de trabalho Parte 1: Interior. [S.l.], 2013. Citado 4 vezes nas páginas 34, 36, 52 e 56.

AL-ENEZI, J. et al. A 'melanopic' spectral efficiency function predicts the sensitivity of melanopsin photoreceptors to polichromatic lights. Journal of Biological Rhythms, v. 26, n. 4, 2011. Citado na página 36.

AMADO, D.; MAZZACORATTI, M. da G. N. O papel da melatonina na eplepsia. Ciência e Cultura, v. 56, n. 1, 2004. Citado na página 31.

ANDERSEN, M.; GOCHENOUR, S. J.; LOCKEY, S. W. Modelling 'non-visual' effects of daylighting in a residential environment. Elsevier - Building and Environment, n. 70, p. 138-149, 2013. Citado 5 vezes nas páginas 25, 34, 35, 36 e 75.

AREAS, R.; DUARTE, L.; MENNA-BARRETO, L. Comparative analysis of rhythmic parameters of the body temperature in humans measured with thermistors and digital thermometers. Biological Rhythm Research, v. 37, n. 5, p. 419-424, 2006. Citado na página 49.

ASCHOFF, J. Circadian systems in man and their implications. Hospital Practice, v. 11, p. 51-57, 1993. Citado na página 47.

BELLIA, L.; SERACENI, M. A proposal for a simplified model to evaluate the circadian effects of light sources. Lighting Research And Technology, n. 46, p. 493-505, 2014. Citado na página 75 .

BERSON, D. M.; DUNN, F. A.; TAKAO, M. Phototransduction by retinal ganglion cells that set the circadian clock. Science Magazine, v. 295, 2002. Citado 2 vezes nas páginas 17 e 25 .

BIGONI, S. Eficiência dos conjuntos óticos de alumínio especular de alto desempenho energético. Dissertação (Mestrado) — Universidade de São Paulo, São Paulo, 2013. Citado na página 37.

BORGES, F. N. da S. Trabalhadores de enfermagem: compreendendo condições de vida e trabalho e ritmos biológicos. Tese (Doutorado) - Faculdade de Saúde Pública Universidade de São Paulo, 2006. Citado 2 vezes nas páginas 10 e 48.

BOYCE, P. R. Reviews of technical reports on daylight and productivity. Lighting Research Center, Rensselaer Polytechnic Institute, 2006. Citado na página 35.

BOYCE, P. R. Human factors in Lighting. 3. ed. Boca Raton, FL, USA: CRC Press, 2014. Citado 4 vezes nas páginas 9, 17, 22 e 23.

BRAINARD, G. C. et al. Action spectrum for melatonin regulation in humans: Evidence for a novel circadian photoreceptor. The Journal of Neuroscience, v. 21, n. 16, p. 6405-6412, 2001. Citado na página 24. 
BULLOUGH, J. D.; REA, M. S.; FIGUEIRO, M. G. Of mice and women: light as a circadian stimulus in breast cancer research. Cancer Causes Control, n. 17, p. 375-383, 2006. Citado na página 30.

BURGESS, H. J.; MOLINA, T. A. Home lighting before usual bedtime impacts circadian timing: A field study. Photochemistry and Photobiology, n. 90, p. 723-726, 2014. Citado 2 vezes nas páginas 37 e 76 .

CIE-TN-003:2015. Report oh the first international workshop on circadian and neurophysiological photometry. CIE - Commission Internationale de l'Eclairage, 2013. Citado 4 vezes nas páginas 10, 41, 42 e 43.

CORNELISSEN, G. Cosinor-based rhythmometry. Cornelissen Theoretical Biology and Medical Modelling, v. 11, n. 16, 2014. Citado 3 vezes nas páginas 10, 47 e 48.

CZEISLER, C. A. et al. Stability, precision and near-24-hour period of the human circadian pacemaker. Science, v. 284, p. 2177, 1999. Citado na página 34.

FABBIAN, F. et al. Dipper and non-dipper blood pressure 24-hour patterns: Circadian rhythm-dependent physiologic and pathophysiologic mechanisms. Chronobiology International, n. 30, p. 17-30, 2013. Citado na página 25.

FEITOSA-SANTANA, C.; MENNA-BARRETO, L. Os três caminhos da luz. Cadernos da primeira oficina de estudos da visão, p. 36-39, 2007. Citado na página 20.

FIGUEIRO, M. A luz e sua relação com a saúde. Revista Lume Arquitetura, v. 44, p. 8-12, 2010. Citado 2 vezes nas páginas 29 e 30.

FIGUEIRO, M. et al. Preliminary evidence that both blue and red light can induce alertness at night. BMC Neuroscience, v. 10, p. 105, 2009. Citado 2 vezes nas páginas 27 e 31.

FOSTER, R.; KREITZMAN, L. Rhythms of Life. 1. ed. Surrey, UK: Profile Books Ltd, 2004. Citado 3 vezes nas páginas 24, 29 e 32.

FOSTER, R. G. et al. Circadian photoreception in the retinally degenerate mouse. Journal of Comparative Physiology A - Neuroethology, Sensory, Neural, and Behavioral Physiology, n. 169, p. 39-50, 1991. Citado na página 25.

GAZZANIGA, M. S. The Cognitive Neurosciences. 3. ed. Cambridge, MA, USA: MIT Press, 2004. Citado na página 20.

GIL, A. carlos. Método e técnicas de pesquisa social. 6. ed. São Paulo: Editora Atlas S.A., 2008. Citado na página 45.

GOEDERT, G. S.; PEREIRA, F. O. R. Verificação metodológica para mapeamento visual em estudos de ofuscamento em ambientes de escritório. 2017. Encontro Nacional de Conforto e Ambiente Construído. Disponível em: < http://www.infohab.org.br/encac/ files/2017/topico6artigo40.pdf>. Acesso em: 10/02/2018. Citado na página 57.

GONÇALVES, B. da S. B. et al. A fresh look at the use of nonparametric analisys in actimetry. Sleep Medicine Reviews, n. 20, p. 84-91, 2015. Citado na página 51. 
HALBERG, F.; TONG, Y. L.; JOHNSON, E. A. Circadian system phase, an aspect of temporal morphology: procedures and illustrative examples. The Cellular Aspects of Biorhythms, p. 20-48, 1967. Citado 2 vezes nas páginas 65 e 67.

HAUGHIAN, S. R. Replacing the batteries on ibutton. [S.l.], 2012. Disponível em: $<$ https://www.researchgate.net/publication/270579725_Replacing_the_batteries_on_ ibutton_Thermochron_Hygrochron_data_loggers $>$. Acesso em: 08/12/2018. Citado na página 60.

HIGGINS, P. A.; HORNICK, T. R.; FIGUEIRO, M. G. Rest-activity and light exposure patterns in the home setting: A methodological case study. American Journal of Alzheimer's Disease $\&$ Other Dementias, v. 25, n. 4, p. 353-361, 2010. Citado na página 50 .

HOAGLIN, D. C.; IGLEWICZ, B.; TUKEY, J. W. Performance of some resistant rules for outlier labeling. Journal of the American Statistical Association, v. 81, n. 396, p. 991-999, 1986. Citado na página 65.

IALD; LIGHTING-EUROPE. Joint position paper by lightingeurope and the iald on human centric lighting. 2017. Citado na página 42.

IESNA. The IESNA Lighting Handbook and Reference application. 9. ed. New York, NY, USA: CRC Press, 2008. Citado 3 vezes nas páginas 9, 21 e 26.

ISA; CSA; CIES. White paper on led general lighting and blue light. 2013. Citado na página 39.

JANSEN, J. M. et al. Medicina da Noite - da cronobiologia à prática. Rio de Janeiro: Editora FIOCRUZ, 2007. Citado na página 71.

KHALSA, S. B. S. et al. The timing of the human circadian clock is accurately represented by the core body temperature rhythm following phase shifts to a three-cycle light stimulus near the critical zone. Journal of Biological Rhythms, v. 15, n. 6, p. 524-530, 2000. Citado na página 67.

KHALSA, S. B. S. et al. A phase response curve to single bright light pulses in human subjects. The Journal of Physiology, v. 549, n. 3, p. 945-952, 2003. Citado na página 67.

KRAFTMAKHER, Y. Nobel prize for blue leds. European Journal of Physics, n. 36, 2015. Citado na página 38.

LESLIE, R. P.; RADETSKY, L. C.; SMITH, A. M. Conceptual design metrics for daylighting. Lighting Research and Technology, n. 0, p. 1-15, 2011. Citado na página 34.

LOCKEY, S. W. Circadian rhythms: Influence of light in humans. Encyclopedia of Neuroscience, v. 2, p. 971-988, 2009. Citado na página 27.

LOCKEY, S. W.; BRAINARD, G. C.; CZEISLER, C. A. High sensitivity of the human circadian melatonin rhythm to resetting by short wavelengh light. The journal of Clinical Endocrinology \&6 Metabolism, v. 88, n. 9, p. 4502-4505, 2003. Citado na página 27.

LUCAS, R. J. et al. Measuring and using light in the melanopsin age. Trends in Neurosciences, v. 37, n. 1, 2014. Citado 5 vezes nas páginas 10, 27, 34, 41 e 44. 
MARTAU, B. T. A luz além da visão: iluminação e sua relação com a saúde e bem-estar de funcionárias de lojas de rua e de shopping centers em Porto Alegre. Tese (Doutorado) - Universidade Estadual de Campinas, Campinas, SP, 2009. Citado 3 vezes nas páginas 9, 27 e 30.

MIRI, M. Luminance-based hdr photos to help lighting designers in they everyday work. Proceedings - Professional Lighting Design Convention, p. 232-235, 2015. Citado na página 57.

MYERS, B. L.; BADIA, P. Immediate effects of different light intensities on body temperature and alertness. Physiology $\&$ Behaviour, v. 54, p. 199-202, 1993. Citado 2 vezes nas páginas 32 e 47.

NAKAMURA, S.; CHICHIBU, S. Introduction to nitride semiconductor blue lasers and light emitting diodes. CRC Press, 1st., 2000. Citado na página 38.

PANDI-PERUMAL, S. R. et al. Melatonin - nature's most versatile biological signal? The FEBS Journal, v. 273, n. 13, p. 2813-2838, 2006. Citado na página 32.

PLITNICK, B. et al. The effects of red and blue light on alertness and mood at night. Lighting Research And Technology, n. 42, p. 449-458, 2010. Citado na página 75.

REA, M. Opinion: On being pc. Lighting Research And Technology, n. 48, p. 266, 2016. Citado na página 75 .

REA, M.; FIGUEIRO, M. G. Light as a circadian stimulus for architectural lighting. Lighting Research Technology, v. 0, p. 1-14, 2016. Citado 4 vezes nas páginas 9, 28, 42 e 75 .

REA, M. S.; BIERMAN, A.; FIGUEIRO, M. G. A new approach to understanding the impact of circadian disruption on human health. Journal of Circadian Rhythms, v. 6, n. 7, 2008. Citado 2 vezes nas páginas 23 e 30.

REA, M. S. et al. Circadian light. Journal of Circadian Rhythms, v. 8, n. 8, 2010. Citado na página 27.

REA, M. S. et al. A model of phototransduction by the human circadian system. Brain Research Review, n. 50, p. 213-228, 2005. Citado 2 vezes nas páginas 13 e 42.

SASSEVILLE, A. et al. Blue blocker glasses impede the capacity of bright light to suppress melatonin production. Journal of Pineal Research, n. 41, p. 73-78, 2006. Citado na página 52.

SHIRANI, A.; LOUIS, E. S. Illuminating rationale and uses for light therapy. Journal of Clinical Sleep Medicine, v. 5, n. 2, 2009. Citado 5 vezes nas páginas 9, 24, 25, 29 e 31.

SIGURDARDOTTIR, L. G. et al. Circadian disruption, sleep loss, and prostate cancer risk: a systematic review of epidemiologic studies. Cancer Epidemiology, Biomarkers and Prevention, v. 21, n. 7, p. 1002:11, 2012. Citado na página 35.

SOUSA-NETO, J. A.; CASTRO, B. F. de. Melatonina, ritmos biológicos e sono - uma revisão da literatura. Revista Brasileira de Neurologia, v. 44, n. 1, 2008. Citado 2 vezes nas páginas 31 e 32. 
SOUSA-NETO, J. A.; SCALDAFERRI, P. M. Melatonina e câncer - revisão da literatura. Revista Brasileira de Cancerologia, v. 51, n. 1, p. 49-58, 2005. Citado na página 31.

SPIVEY, A. The mixed blessing of phosphor-based white leds. Environmental Health Perspectives, v. 119, n. 11, 2011. Citado 2 vezes nas páginas 10 e 39.

TOSINI, G.; FERGUSON, I.; TSUBOTA, K. Effects of blue light on the circadian system and eye physiology. Molecular Vision, n. 22, p. 61-72, 2016. Citado 4 vezes nas páginas $26,35,38$ e 75 .

TOSINI, G. et al. The circadian clock system in the mammalian retina. BioEssays - Wiley Periodicals, v. 30, n. 7, p. 624-633, 2008. Citado 3 vezes nas páginas 25, 26 e 29.

WOOD, B. et al. Light level and duration of exposure determine the impact of self-luminous tablets on melatonin suppression. Applied Ergonomics, n. 44, p. 237-240, 2013. Citado na página 75.

ZEITZER, J. M. et al. Sensitivity of the human circadian pacemaker to nocturnal light: melatonin phase resetting and suppression. Journal of Psysiology, v. 526, n. 3, p. 695-702, 2000. Citado na página 35. 
Apêndices 


\section{APÊNDICE A - Instruções diárias para os procedimentos do Estudo de Caso}

Resposta Humana à Luz: Alterações não visuais e as diretrizes para o projeto luminotécnico residencial com LEDs (FAU-USP)

Instruções Diárias para os Procedimentos da Pesquisa

Dia 1 - Início do estudo. Neste dia evitar cafeína (café, coca-cola, guaraná, etc.), exercício físico e bebidas alcoólicas.

- 19 h00 às $07 h 00$ (12 horas) - Coleta de Urina noturna

- 19 h00 - Esvaziar a bexiga, desprezando esta urina;

- A partir das 19h00: Coletar toda a urina noturna no frasco grande.

\section{Dia 2}

- 07 h00 - Efetuar a última coleta de urina no frasco grande e fazer a leitura do volume total coletado (em ml);

- Anotar no frasco pequeno com o número 1 (tampa vermelha) o volume total coletado (em ml);

- Transferir para o frasco pequeno uma amostra de $10 \mathrm{ml}$ da urina total coletada. Feche bem a tampa e coloque este frasco imediatamente no congelador;

- Descartar o frasco grande;

- Congelar o frasco com tampa vermelha contendo a amostra de número 1.

- 19 h00 até ir dormir - Uso dos óculos laranja. Caso acorde no meio da noite, utilizá-los enquanto houver luzes acesas.

Dia 3

- $19 h 00$ até ir dormir - Uso dos óculos laranja. Caso acorde no meio da noite, utilizá-los enquanto houver luzes acesas.

Dia 4 - Neste dia evitar cafeína (café, coca-cola, guaraná, etc.), exercício físico e bebidas alcoólicas.

- 19 h00 até ir dormir - Uso dos óculos laranja. Caso acorde no meio da noite, utilizá-los enquanto houver luzes acesas.

- 19 h00 às 07h00 (12 horas) - Coleta de Urina noturna

- 19 h00 - Esvaziar a bexiga, desprezando esta urina;

- A partir das 19h00: Coletar toda a urina noturna no frasco grande. 


\section{Dia 5}

- $07 h 00$ - Efetuar a última coleta de urina no frasco grande e fazer a leitura do volume total coletado (em ml);

- Anotar no frasco pequeno com o número 2 (tampa vermelha) o volume total coletado $(\mathrm{em} \mathrm{ml})$;

- Transferir para o frasco pequeno uma amostra de $10 \mathrm{ml}$ da urina total coletada. Feche bem a tampa e coloque este frasco imediatamente no congelador;

- Descartar o frasco grande;

- Congelar o frasco com tampa vermelha contendo a amostra de número 2.

- $19 h 00$ até ir dormir - Período de exposição à iluminação LED. Neste período, deixar todas as luzes acesas para melhor exposição. Evitar ou minimizar a exposição às luzes de equipamentos eletrônicos.

\section{Dia 6}

- 19 h00 até ir dormir - Período de exposição à iluminação LED. Neste período, deixar todas as luzes acesas para melhor exposição. Evitar ou minimizar a exposição às luzes de equipamentos eletrônicos.

Dia 7 - Neste dia evitar cafeína (café, coca-cola, guaraná, etc.), exercício físico e bebidas alcoólicas.

- 19 h00 até ir dormir - Período de exposição à iluminação LED. Neste período, deixar todas as luzes acesas para melhor exposição. Evitar ou minimizar a exposição às luzes de equipamentos eletrônicos.

- 19 h00 às 07h00 (12 horas) - Coleta de Urina noturna

- $19 \mathrm{~h} 00$ - Esvaziar a bexiga, desprezando esta urina;

- A partir das 19h00: Coletar toda a urina noturna no frasco grande.

\section{Dia 8}

- $07 h 00$ - Efetuar a última coleta de urina no frasco grande e fazer a leitura do volume total coletado (em ml);

- Anotar no frasco pequeno com o número 3 (tampa vermelha) o volume total coletado (em $\mathrm{ml}$ );

- Transferir para o frasco pequeno uma amostra de $10 \mathrm{ml}$ da urina total coletada. Feche bem a tampa e coloque este frasco imediatamente no congelador;

- Descartar o frasco grande;

- Congelar o frasco com tampa vermelha contendo a amostra de número 3.

\section{- FIM DO ESTUDO.}




\section{APÊNDICE B - TCLE - Termo de Consentimento Livre e Esclarecido}

TERMO DE CONSENTIMENTO LIVRE E ESCLARECIDO

AUTORIZAÇÃO PARA PARTICIPAR DE UM PROJETO DE PESQUISA

Nome do Estudo: Verificação quantitativa e qualitativa da iluminaçăo artificial residencial de LEDs no ambiente residencial e seu impacto nos ritmos biológicos, como parte da dissertação de mestrado "Resposta Humana à Luz: Alteraçôes não visuais e as diretrizes para o projeto luminotécnico residencial com LEDs" (FAU-USP)

Pesquisador responsável: Ruy Barbosa Soares Filho

1. Objetivos deste estudo:

- Verificar as características dos sistemas de iluminaçăo artificial residencial com LEDs e sua influência nos ritmos biológicos dos usuários;

- Averiguar o potencial circadiano noturno dos ambientes residenciais iluminados por LEDs.

Este estudo permitirá estabelecer a relação entre os sistemas de iluminação utilizados nas residências e os reflexos na saúde dos usuários. Esta compreensão é importante para o estabelecimento de novos parâmetros a serem observados para os projetos luminotécnicos residenciais com LEDs.

2. Explicação dos procedimentos: Você está sendo convidado(a) a participar deste estudo de modo voluntário. Caso concorde, inicialmente você precisará responder a 4 questionários com a duraçăo total de 30 minutos. A partir do resultado dos referidos questionários, o pesquisador fará uma visita à sua residência para aferições da iluminação existente nos ambientes de maior permanência à noite Você receberá equipamentos eletrônicos para serem utilizados como colar e como relógio de pulso para registrar seus movimentos, pressăo arterial, frequência cardíaca e exposição à luz, além de um termistor a ser colocado no lado interno do punho para registrar sua temperatura. Estes equipamentos deverão ser utilizados durante sete dias consecutivos. Com exceção do termistor, os equipamentos devem ser retirados durante o banho. Somente o colar deve ser retirado enquanto você estiver dormindo. Estes equipamentos deverão ser devolvidos ao pesquisador ao final do estudo. $O$ uso dos referidos equipamentos provavelmente não irá afetar suas atividades diárias, pois são muito pequenos e dispensam cuidados especiais. As informaçães registradas pelos equipamentos estão relacionadas à avaliação da influência da iluminação nos ritmos biológicos que ocorrem ao longo das 24 horas do dia. Para este estudo será necessário verificar a produçăo do hormônio melatonina por meio de três coletas de urina noturna ( 12 horas) na primeira, quarta e sétima noite, em frascos a serem fornecidos pelo pesquisador.

3. Possiveis riscos e desconfortos: Os possíveis desconfortos deste estudo estão relacionados às perguntas realizadas nos questionários, ao uso dos equipamentos de coleta de dados no punho (com pequeno risco de provocar irritaçăo na pele, caso em que os equipamentos deverão ser imediatamente retirados e o estudo deverá ser interrompido) durante sete dias ininterruptos e à coleta de urina noturna durante três noites ao longo do estudo.

4. Possíveis beneficios deste estudo: A iluminação é um importante regulador dos ritmos biológicos. A exposiçăo à luz noturna, especialmente àquela produzida pelos LEDs, tem sido relacionada a vários distúrbios físicos e emocionais. Como benefício direto, você receberá a avaliação das características dos sistemas de iluminação artificial dos ambientes de maior permanência noturna de sua residência, possíveis efeitos negativos destes sistemas à sua saúde e, se desejar, poderá receber orientaçốes de medidas para minimizar tais efeitos, a partir dos resultados deste estudo.

5. Interrupção do Estudo: $O$ estudo poderá ser interrompido caso sejam identificados fatores que possam gerar algum tipo de prejuízo para você, ou seja, alguma situaçăo imprevista ou o năo cumprimento das recomendaçôes estabelecidas no projeto.

6. Direito de desistência: Você pode desistir de participar a qualquer momento. Sua decisão e não participar ou de deixar a pesquisa depois de iniciada não afetará as orientações a serem fornecidas a partir dos resultados deste estudo.

7. Confidencialidade: Os dados de identificação pessoal dos participantes deste estudo não serão divulgados ou publicados.

8. Consentimento: Caso você necessite maiores informaçǒes, o pesquisador responsável Ruy Soares (11 98384-9617), o Comitê de Ética em Pesquisa Envolvendo Seres Humanos da EACH - USP (11 3091-1046) e a diretoria da Faculdade de Arquitetura e Urbanismo da Universidade de Säo Paulo (11 3091-4307) podem ser consultados.

Este documento possui duas vias, sendo que uma ficará com o participante e outra com o pesquisador

Declaro ter lido - ou que me foi lido - as informaçōes acima antes de assinar este formulário. Foi-me dada ampla oportunidade de fazer perguntas, esclarecendo plenamente minhas dúvidas. Por este instrumento tomo parte, voluntariamente, do presente estudo.

Assinatura do participante da pesquisa

Assinatura do pesquisador responsável
Assinatura da testemunha

São Paulo, _ d _ _ de 201 


\section{APÊNDICE C - Análises de Cosinor - Temperatura Corporal}

\begin{tabular}{|c|c|c|c|}
\hline \multicolumn{2}{|c|}{ Sujeito A - Antes } & \multirow{2}{*}{$\begin{array}{c}\text { Cosinor } \\
\text { Dados : Temperatura } \\
\text { Alfa : } 0.05(95.00 \%)\end{array}$} & \multirow{2}{*}{$\frac{\text { Temperatura Corporal }}{\text { Duração do Ciclo : } 12.5664}$} \\
\hline $\begin{array}{l}\text { Data Inicial :09/10/17 } \\
\text { Data Final : } 11 / 10 / 17\end{array}$ & $\begin{array}{l}\text { Hora Inicial : 00:00:00 } \\
\text { Hora Final : 00:00:00 }\end{array}$ & & \\
\hline Mesor : 34.9838 & ude : 0.769047 & se : -0.538484 (radianos) & ) Acrofase : 02:03:24 (tempo) \\
\hline
\end{tabular}

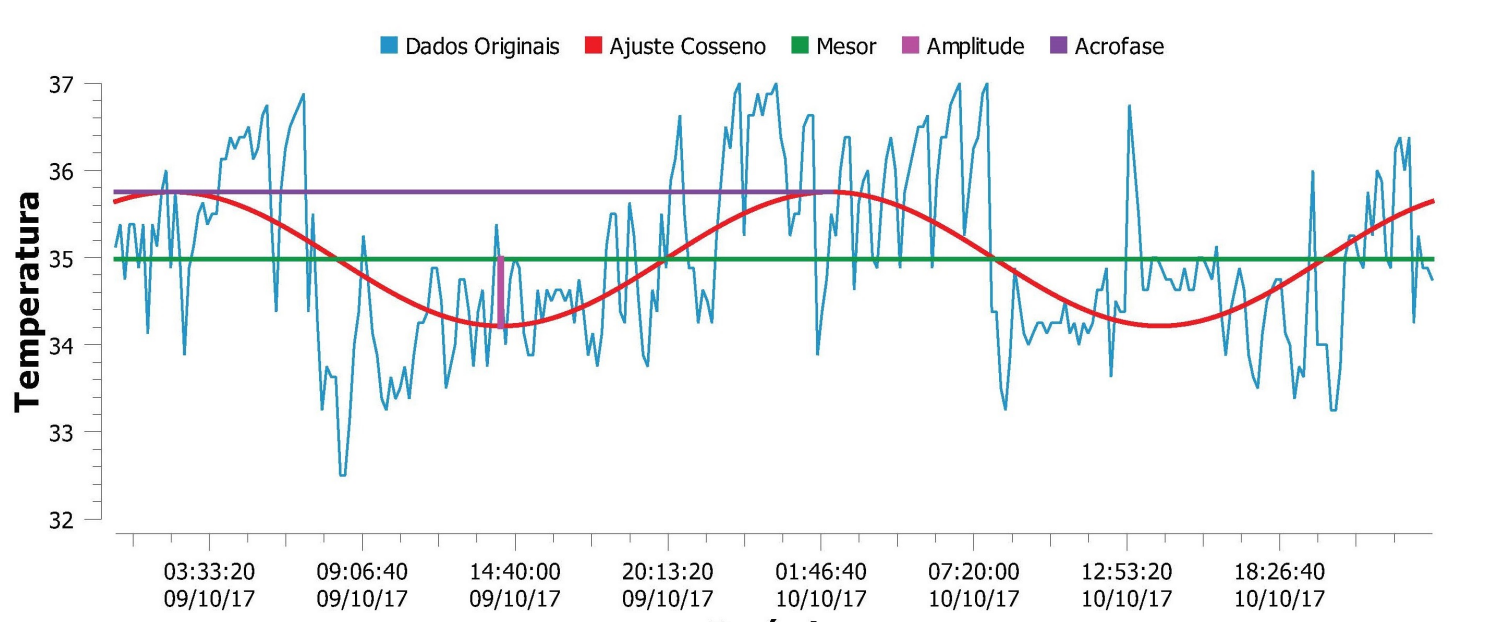

Período

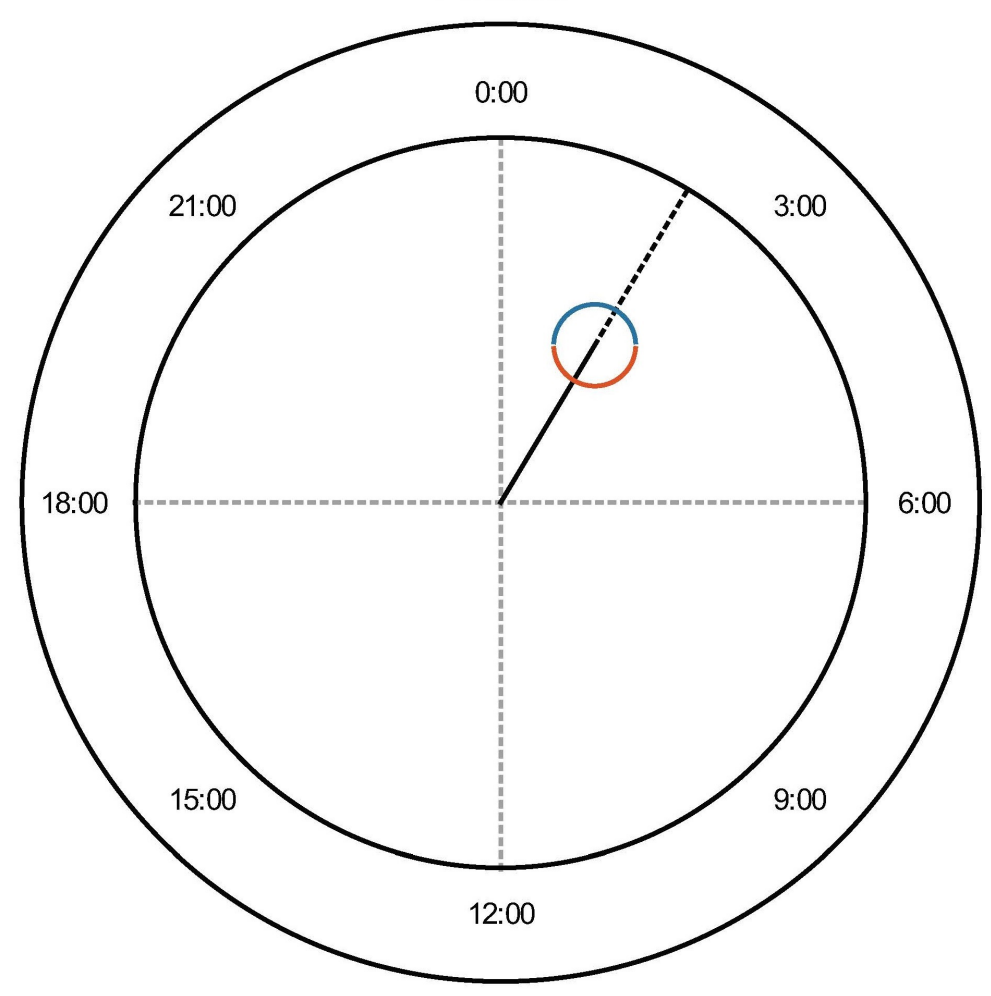



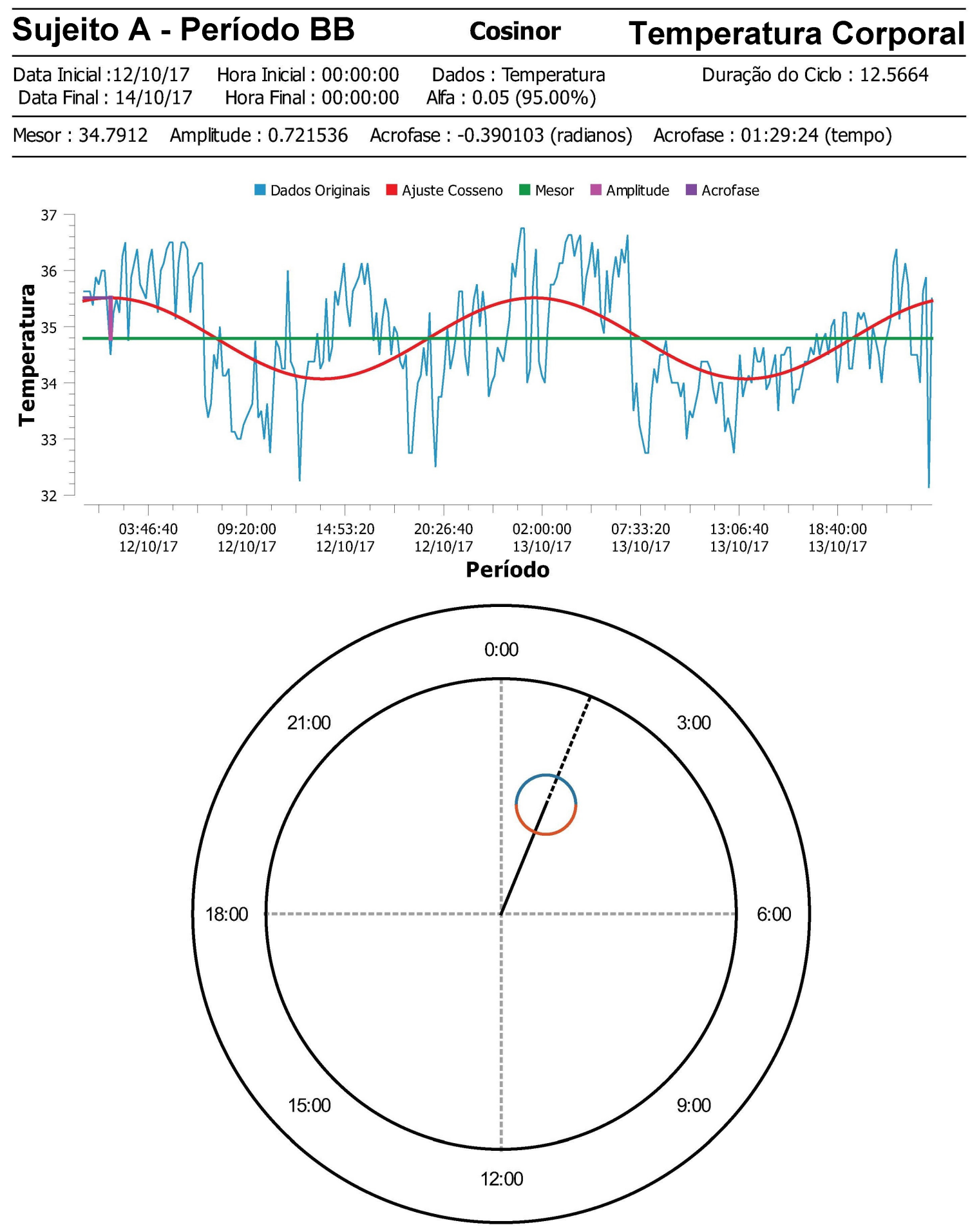


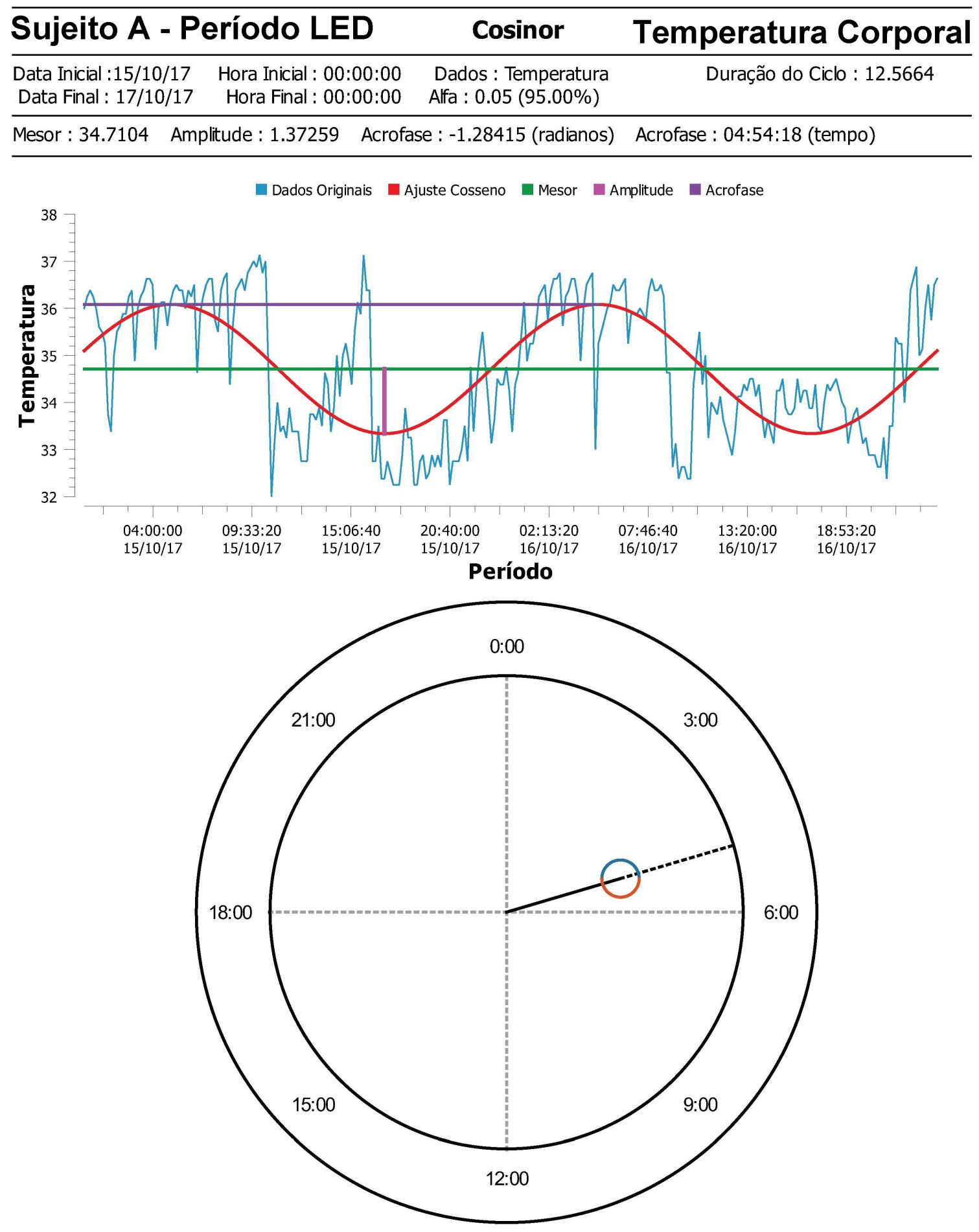




\begin{tabular}{|c|c|c|c|}
\hline \multicolumn{2}{|c|}{ Sujeito B - Antes } & \multirow{2}{*}{$\begin{array}{c}\text { Cosinor } \\
\text { Dados : Temperatura } \\
\text { Alfa : } 0.05(95.00 \%)\end{array}$} & \multirow{2}{*}{$\begin{array}{c}\text { Temperatura Corpora } \\
\text { Duração do Ciclo : } 12.5664\end{array}$} \\
\hline $\begin{array}{l}\text { Data Inicial : } 30 / 10 / 17 \\
\text { Data Final : } 01 / 11 / 17\end{array}$ & $\begin{array}{l}\text { Hora Inicial : 00:00:00 } \\
\text { Hora Final : 00:00:00 }\end{array}$ & & \\
\hline Mesor : 34.1617 & plitude : 1.04047 Acrofó & se : -0.889884 (radianos) & Acrofase : 03:23:56 (tempo) \\
\hline
\end{tabular}

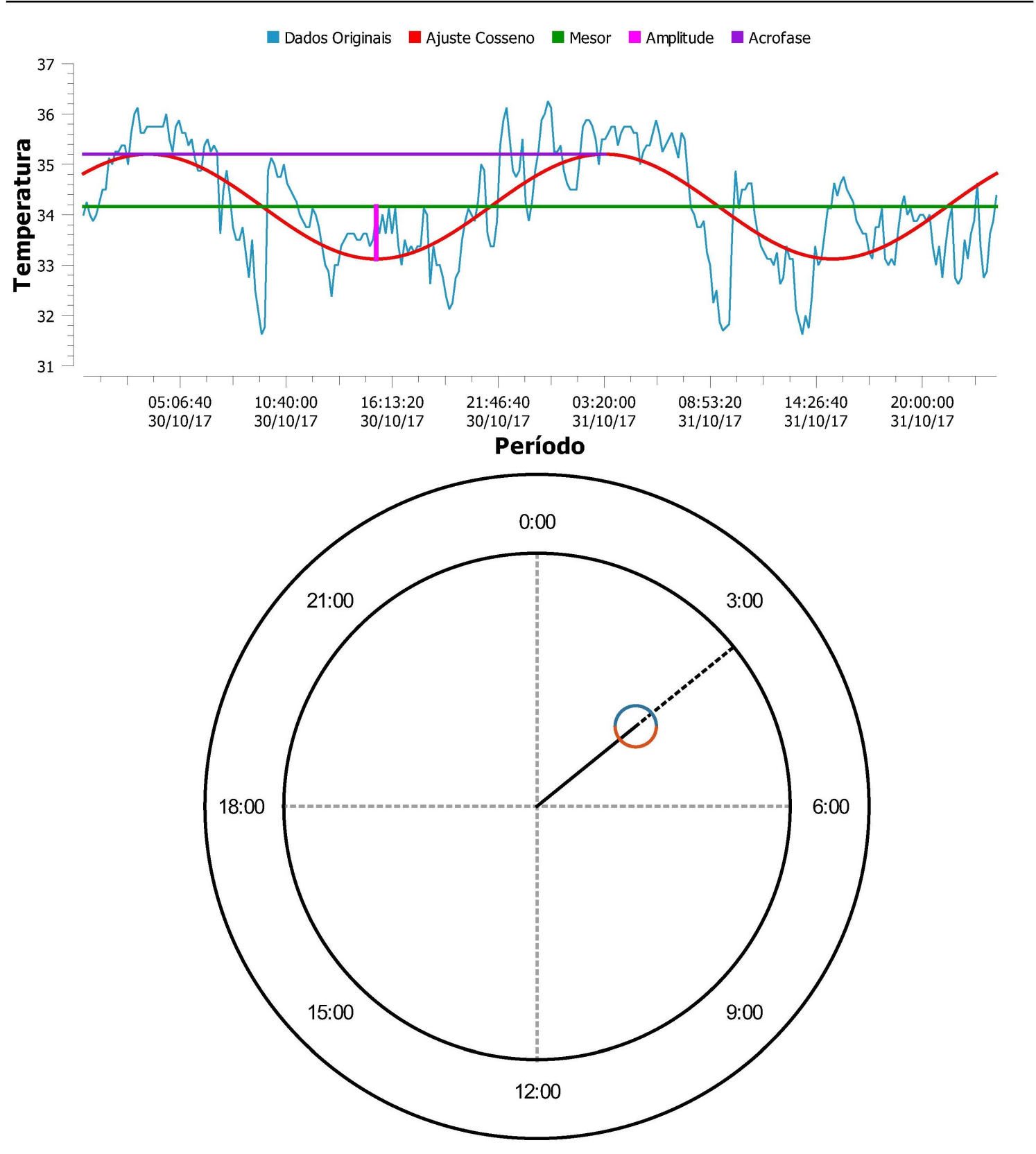




\section{Sujeito B - Período BB}

\section{Cosinor}

Temperatura Corporal

Data Inicial :02/11/17 Hora Inicial : 00:00:00 Dados : Temperatura Data Final : 04/11/17 Hora Final : 00:00:00 Alfa : 0.05 (95.00\%)

Mesor : 34.4407 Amplitude : 0.706197 Acrofase : -0.540728 (radianos) Acrofase : 02:03:55 (tempo)

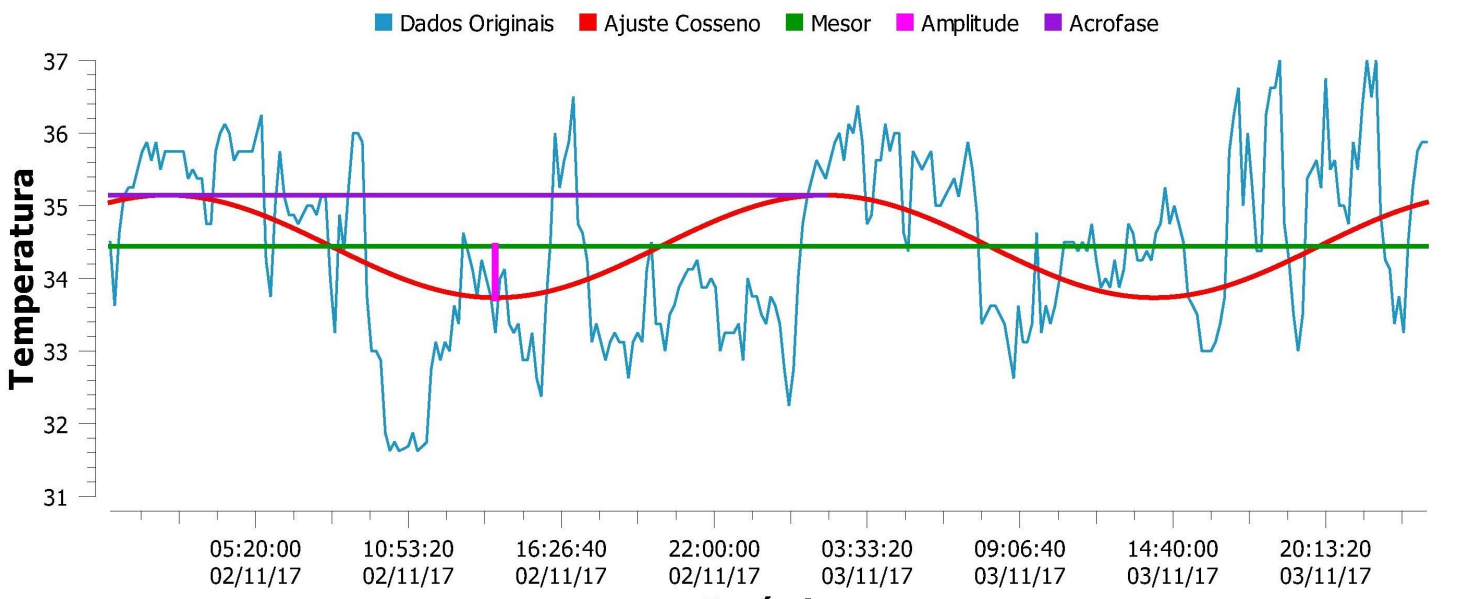

Período

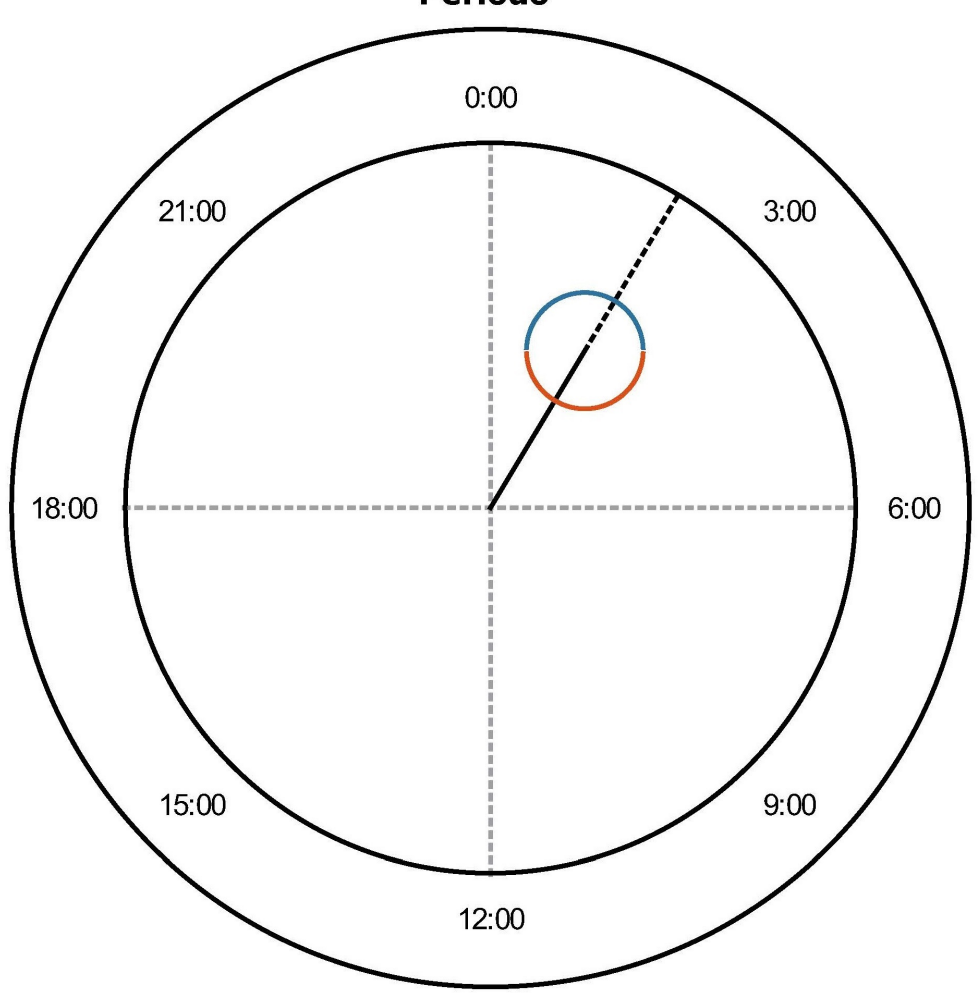




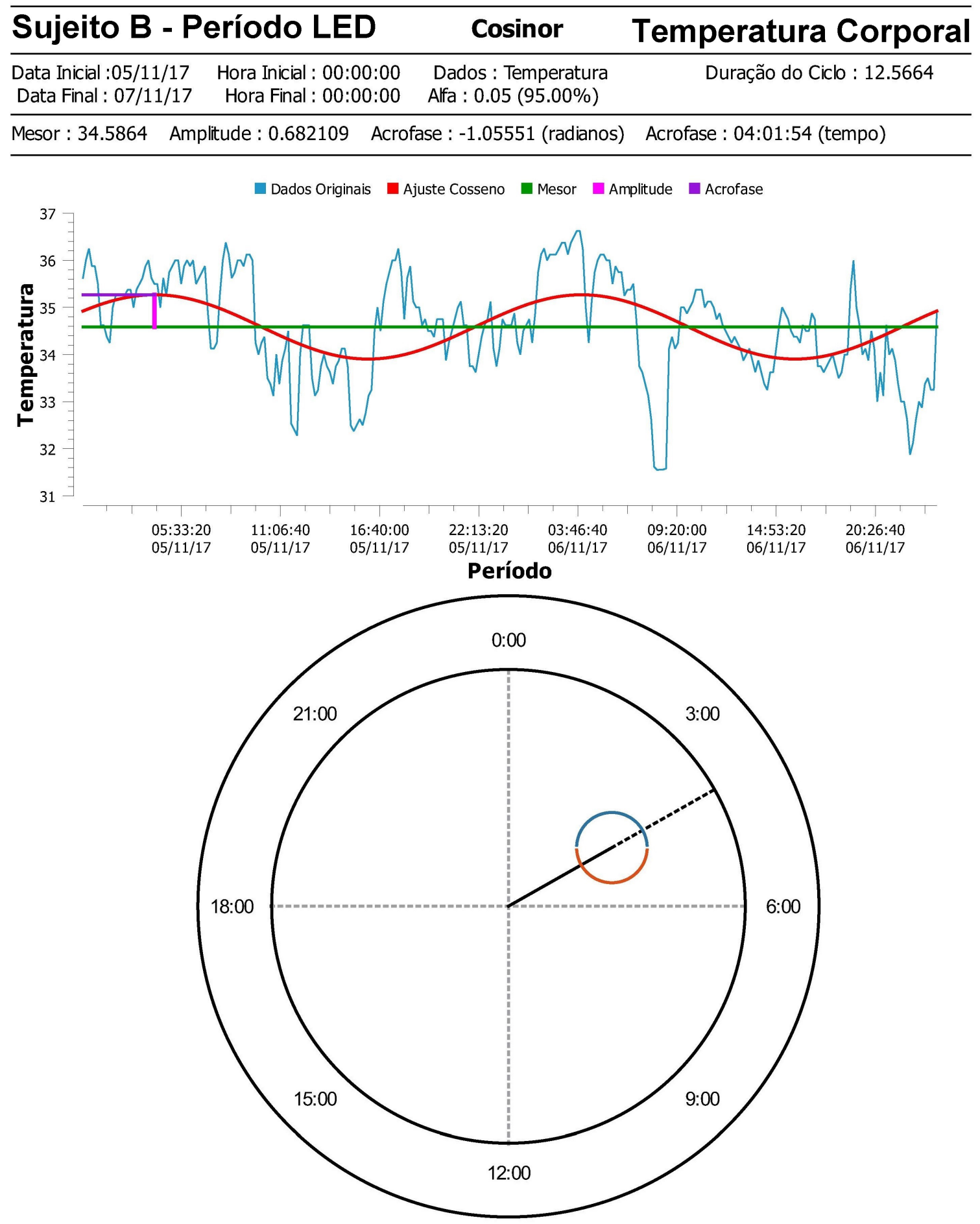




\section{Sujeito C - Antes}

\section{Cosinor}

Temperatura Corporal

Data Inicial :06/11/17 Hora Inicial : 00:00:00 Dados : Temperatura

Data Final : 08/11/17 Hora Final : 00:00:00 Alfa : $0.05(95.00 \%)$

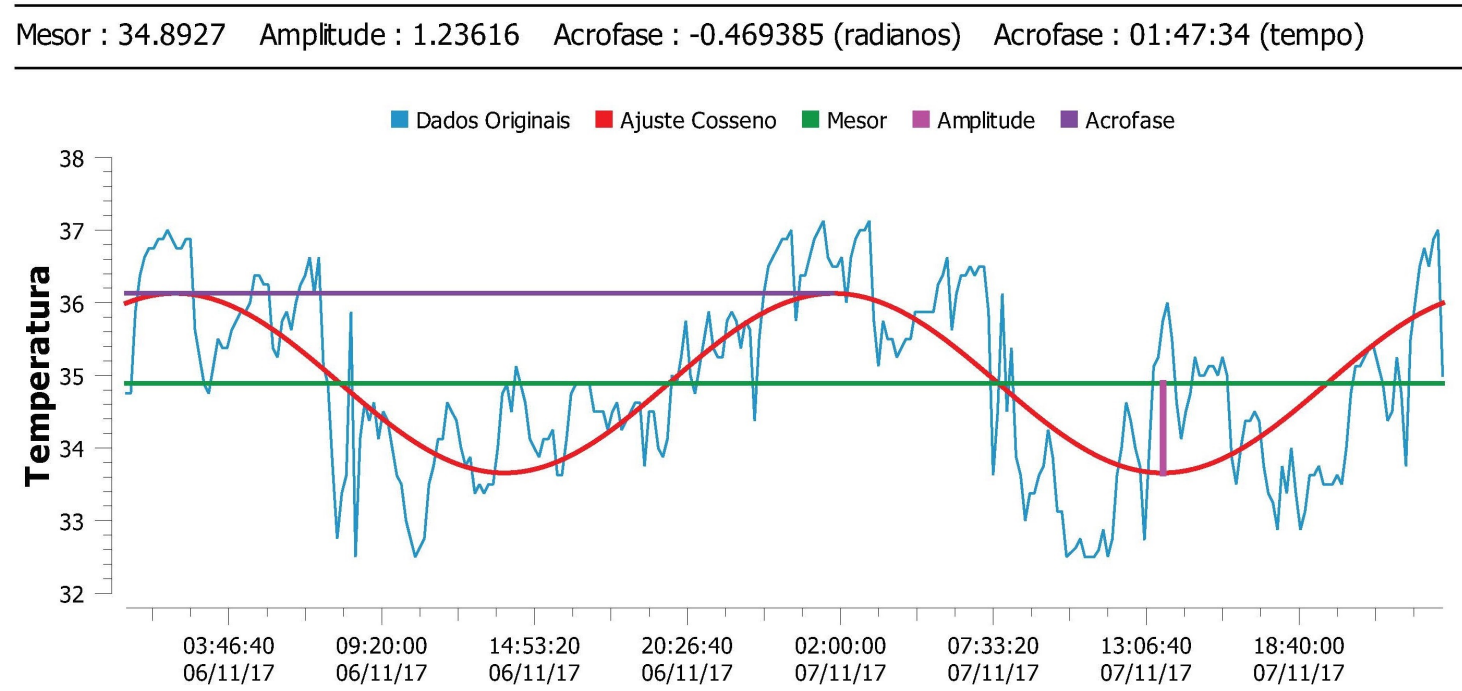

Período

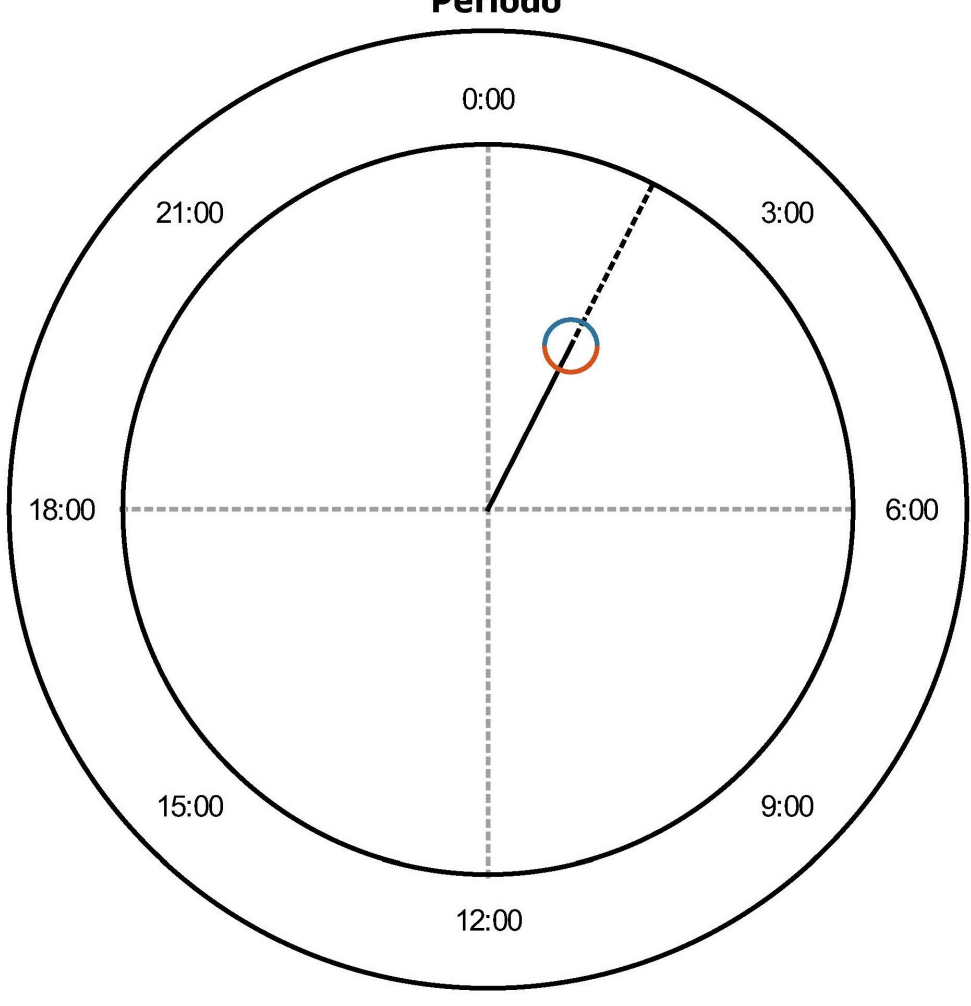




\section{Sujeito C - Periodo BB}

\section{Cosinor}

\section{Temperatura Corporal}

Data Inicial :09/11/17 Hora Inicial : 00:00:00 Dados : Temperatura

Duração do Ciclo : 12.5664

Data Final : $11 / 11 / 17$ Hora Final : 00:00:00 Alfa : $0.05(95.00 \%)$

Mesor : 35.2356 Amplitude : 0.538172 Acrofase : -0.302762 (radianos) Acrofase : 01:09:23 (tempo)

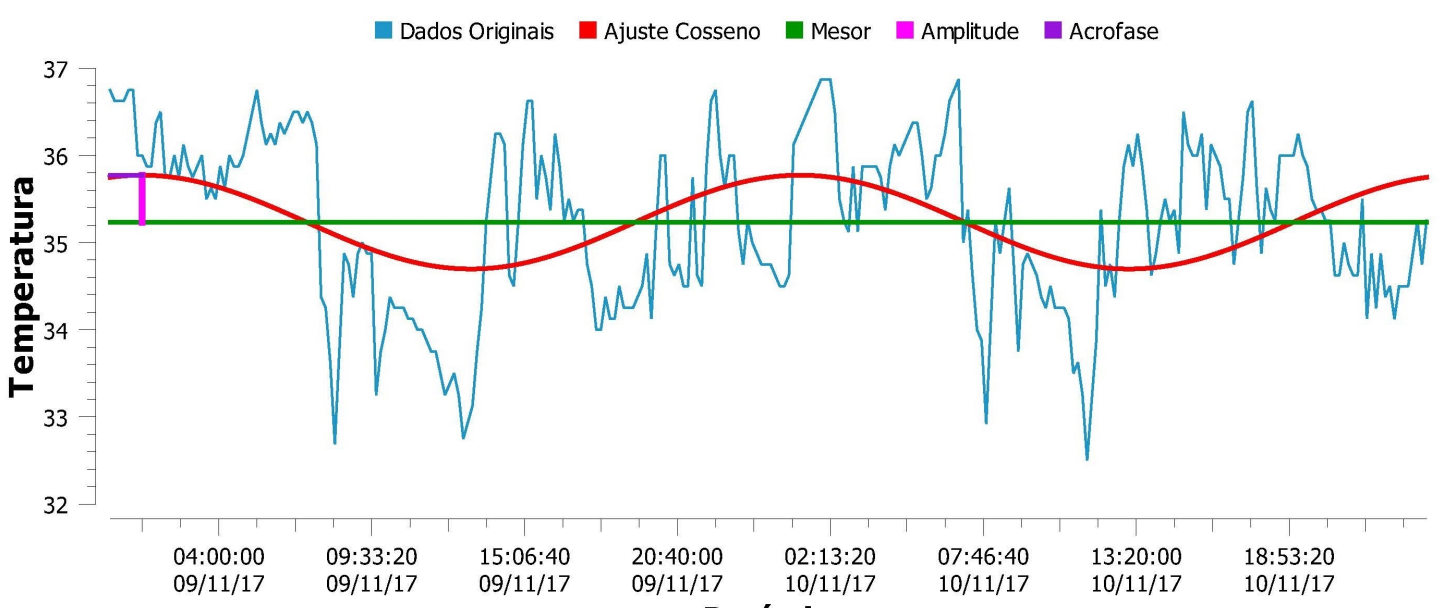

Período

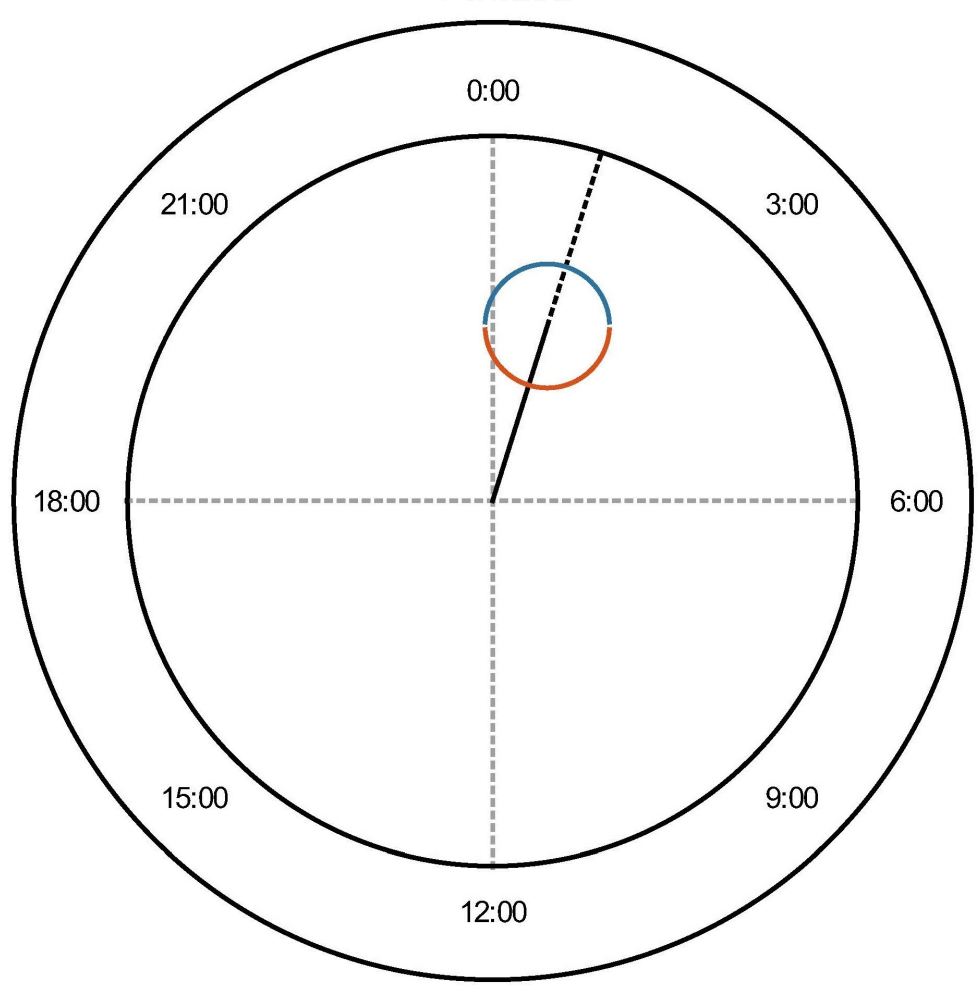




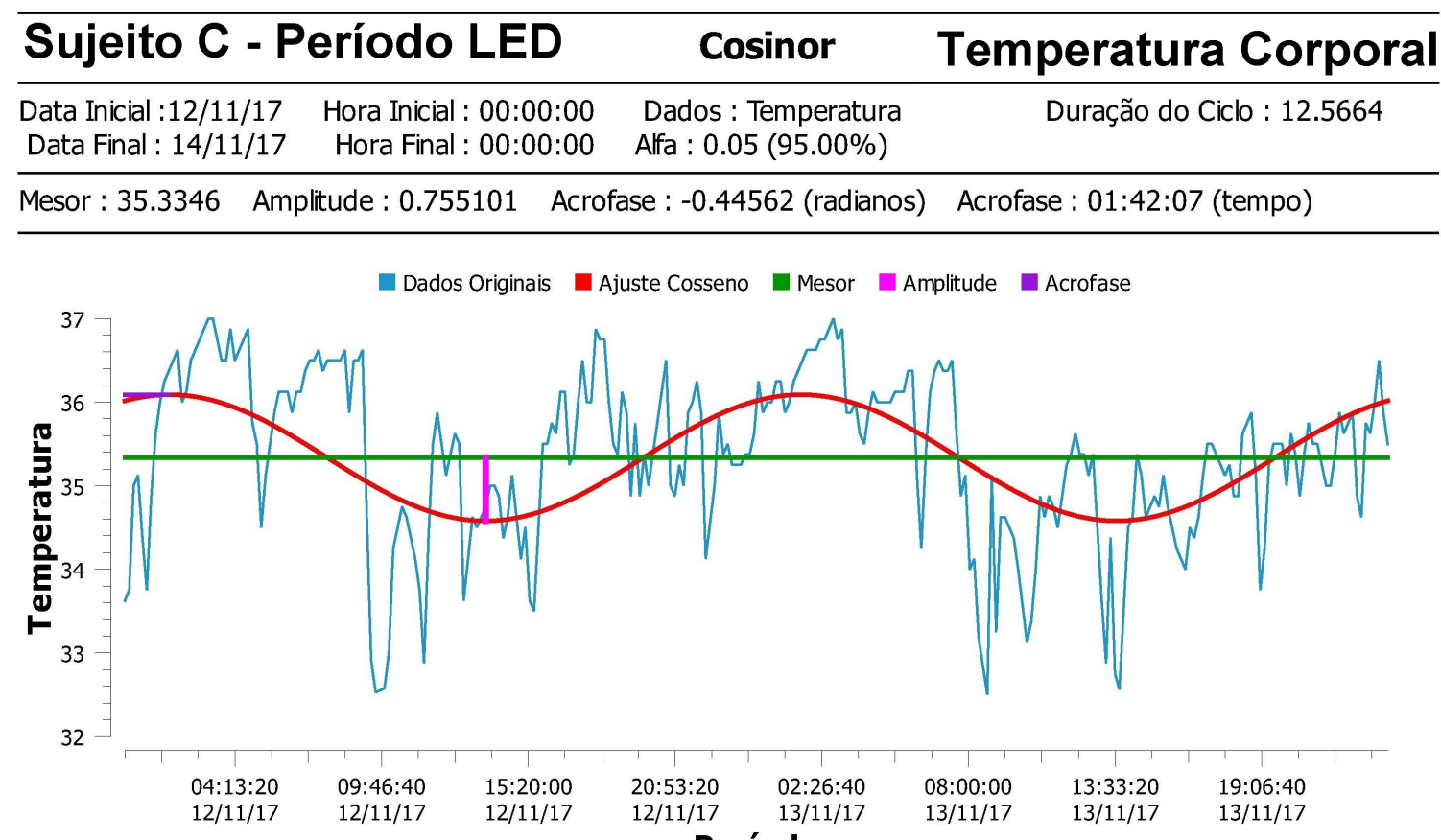

Período

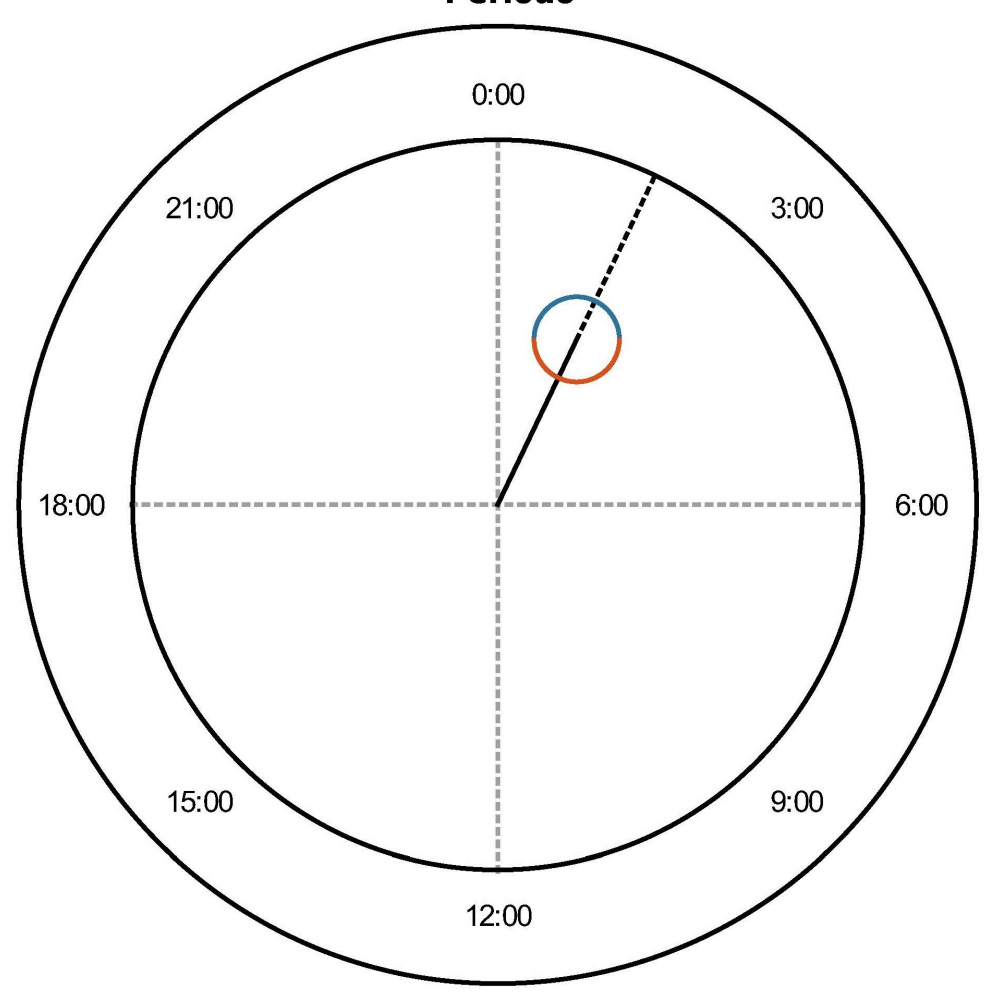




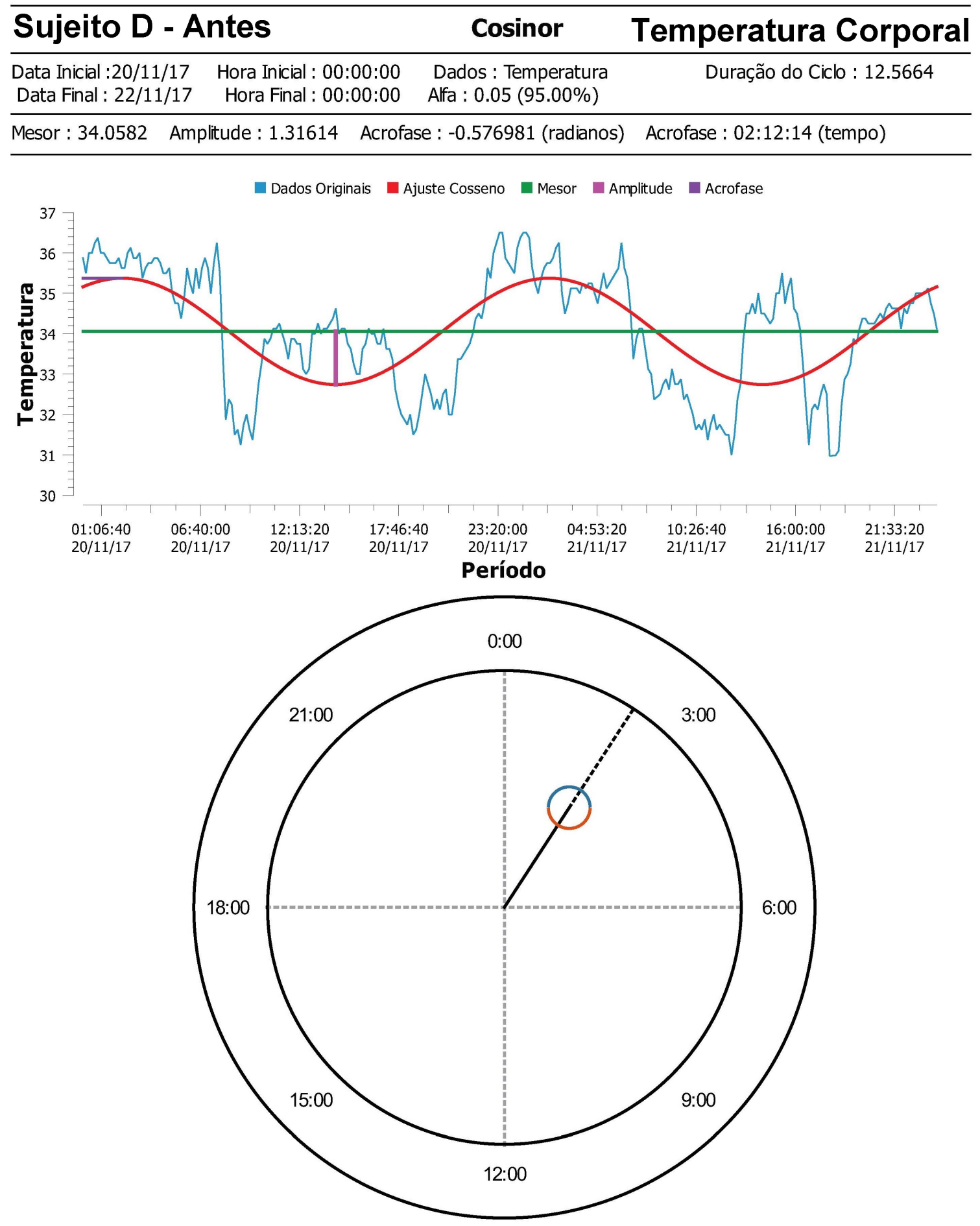




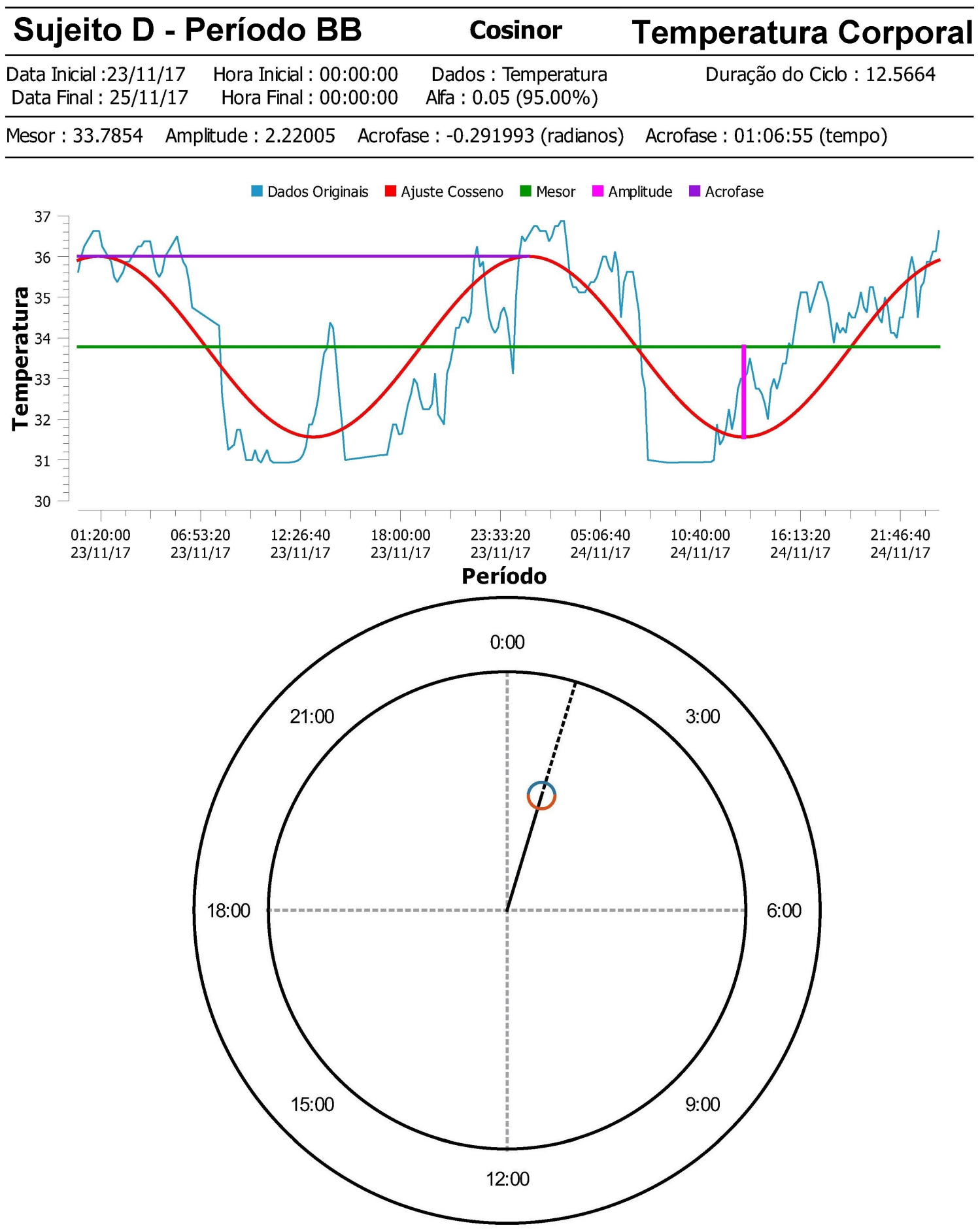




\begin{tabular}{|c|c|c|c|}
\hline \multicolumn{2}{|c|}{ Sujeito D - Período LED } & \multirow{2}{*}{$\begin{array}{c}\text { Cosinor } \\
\text { Dados : Temperatura } \\
\text { Alfa : } 0.05(95.00 \%)\end{array}$} & \multirow{2}{*}{$\frac{\text { Temperatura Corporal }}{\text { Duração do Ciclo : } 12.5664}$} \\
\hline $\begin{array}{l}\text { Data Inicial : } 26 / 11 / 17 \\
\text { Data Final : } 28 / 11 / 17\end{array}$ & $\begin{array}{l}\text { Hora Inicial : 00:00:00 } \\
\text { Hora Final : 00:00:00 }\end{array}$ & & \\
\hline Mesor : 34.4633 An & olitude : 1.32175 Acrofa & se : -0.370021 (radianos) & Acrofase : 01:24:48 (tempo) \\
\hline
\end{tabular}

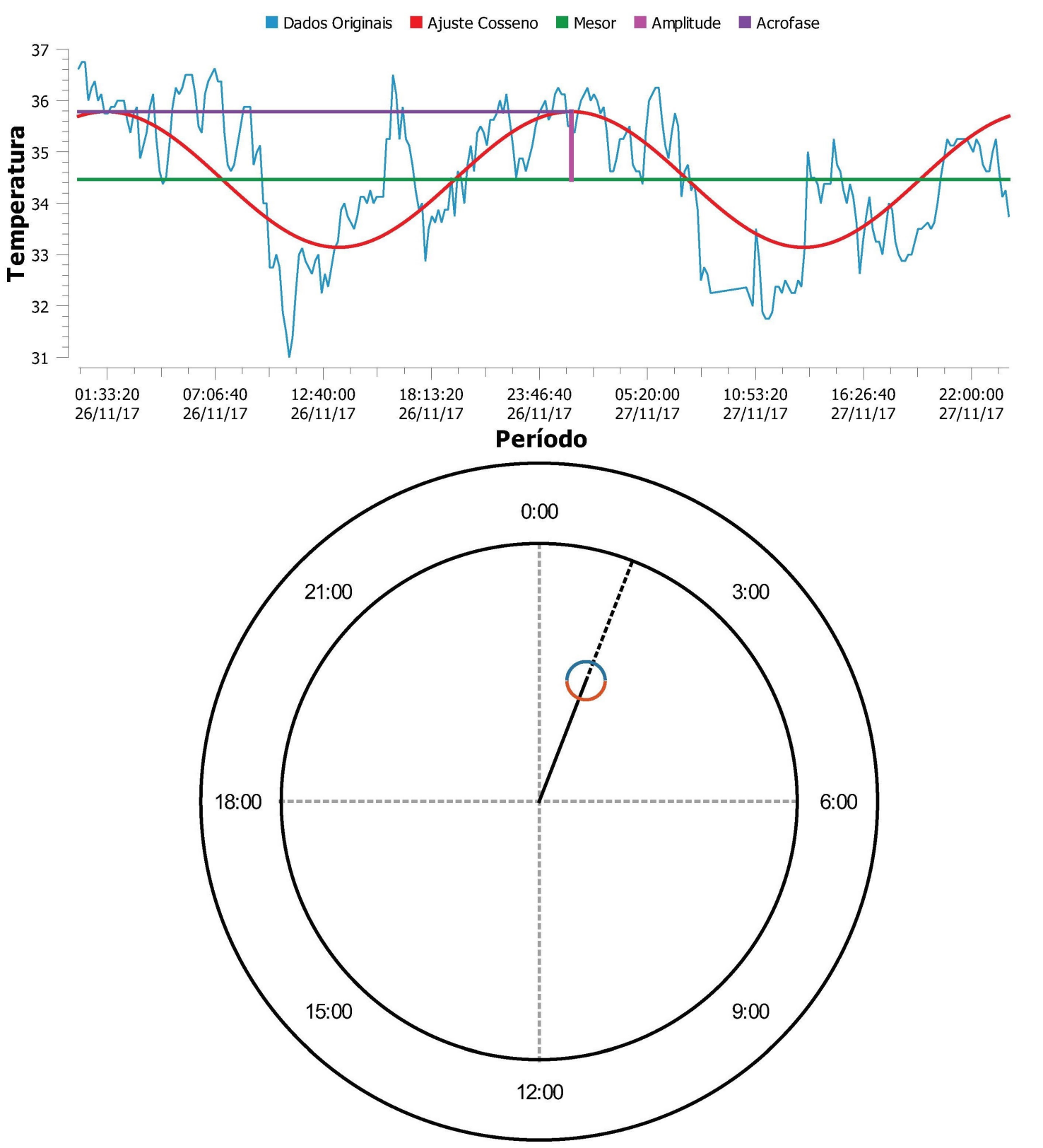




\section{Sujeito E - Antes}

\section{Cosinor}

Temperatura Corporal

Data Inicial :20/11/17 Hora Inicial : 00:00:00 Dados : Temperatura

Duração do Ciclo : 12.5664

Data Final : 22/11/17 Hora Final : 00:00:00 Alfa : $0.05(95.00 \%)$

Mesor : 34.8747 Amplitude : 0.796954 Acrofase : -1.04472 (radianos) Acrofase : 03:59:25 (tempo)
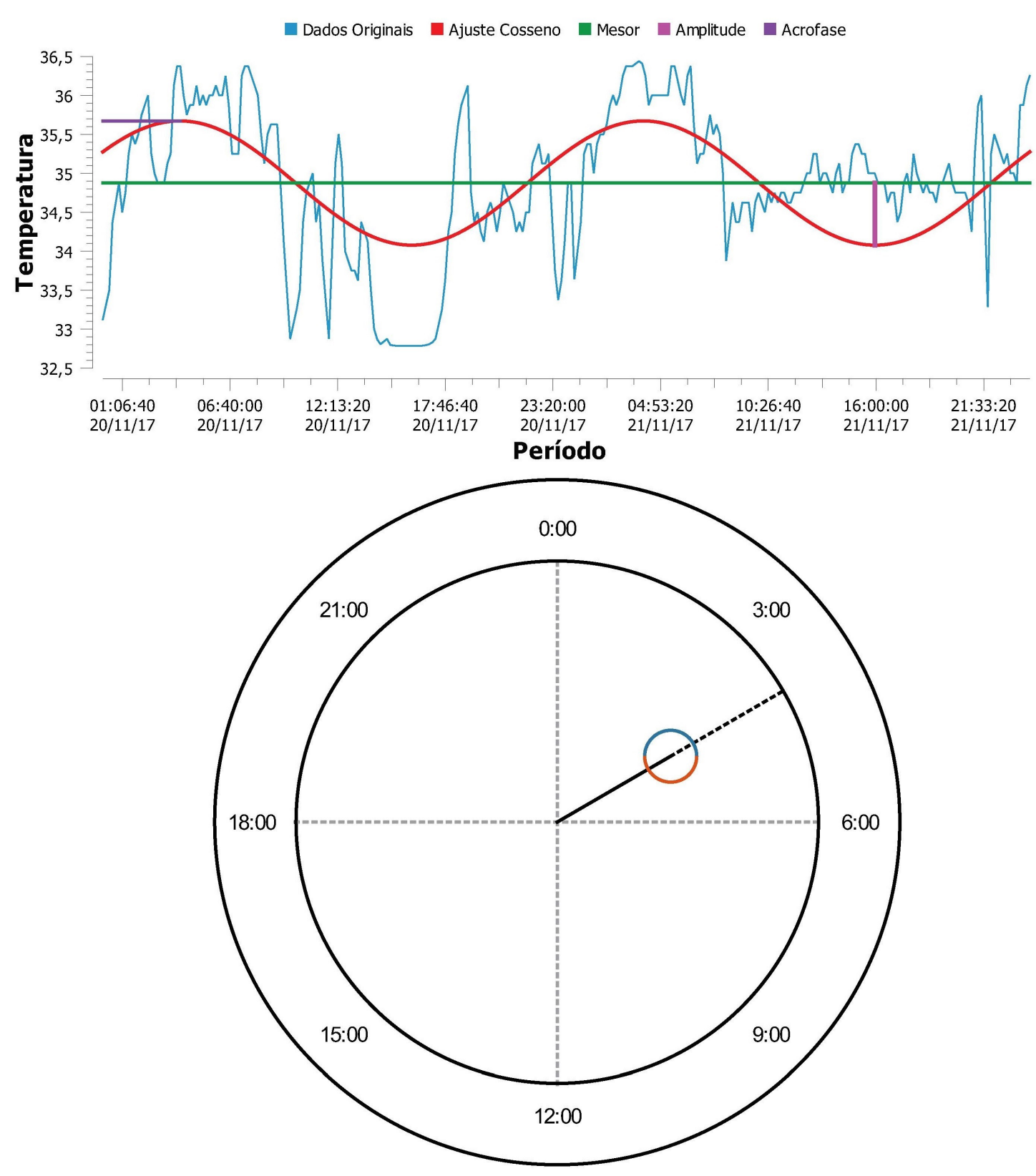


\begin{tabular}{|c|c|c|c|}
\hline \multicolumn{2}{|c|}{ Sujeito E - Período BB } & \multirow{2}{*}{$\begin{array}{c}\text { Cosinor } \\
\text { Dados : Temperatura } \\
\text { Alfa : } 0.05(95.00 \%)\end{array}$} & \multirow{2}{*}{$\frac{\text { Temperatura Corporal }}{\text { Duração do Ciclo : } 12.5664}$} \\
\hline $\begin{array}{l}\text { Data Inicial :23/11/17 } \\
\text { Data Final : 25/11/17 }\end{array}$ & $\begin{array}{l}\text { Hora Inicial : 00:00:00 } \\
\text { Hora Final : 00:00:00 }\end{array}$ & & \\
\hline Mesor : 34.338 & ude : 0.821081 & se : -0.991387 (radianos) & Acrofase : 03:47:12 (tempo) \\
\hline
\end{tabular}

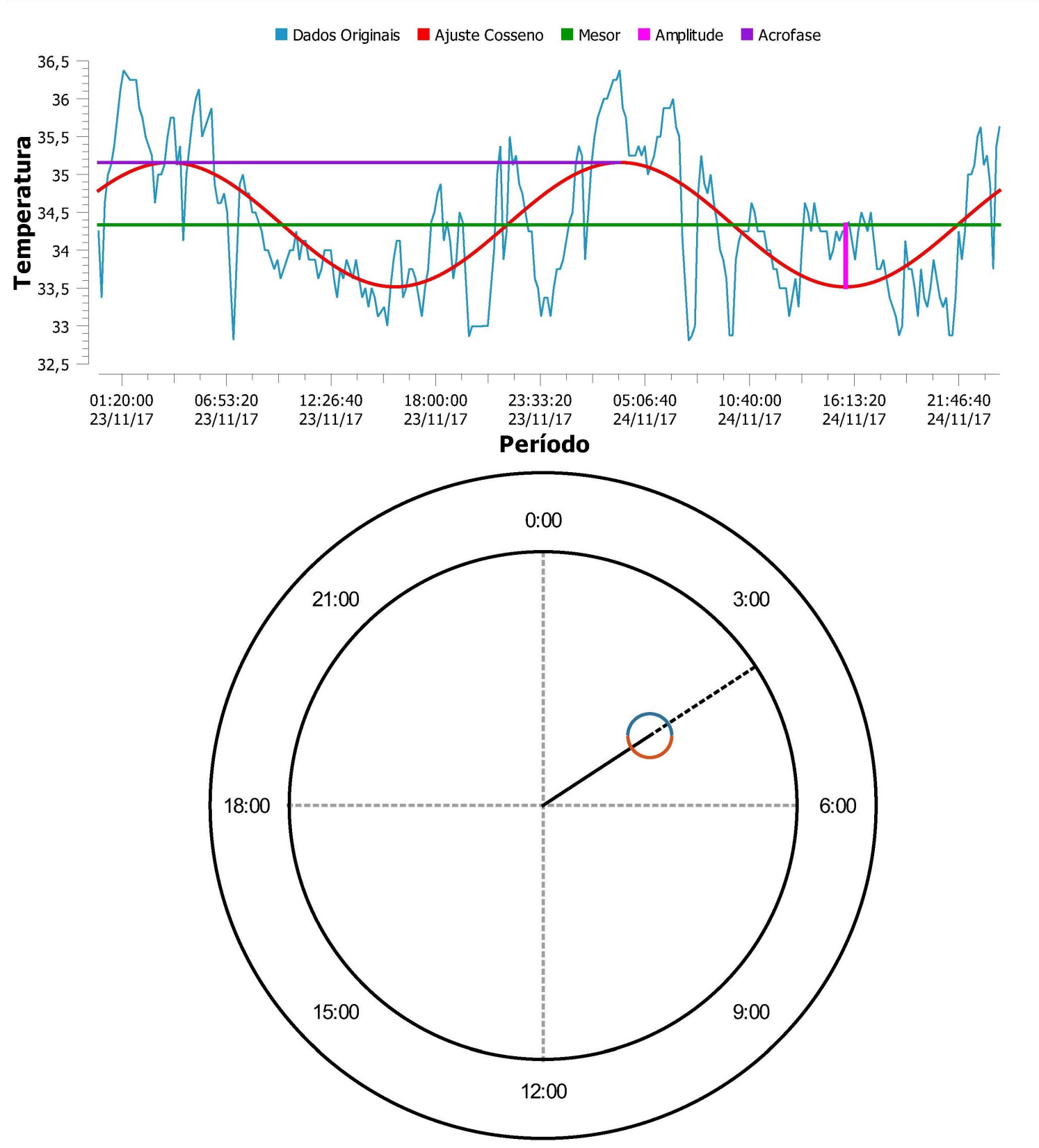




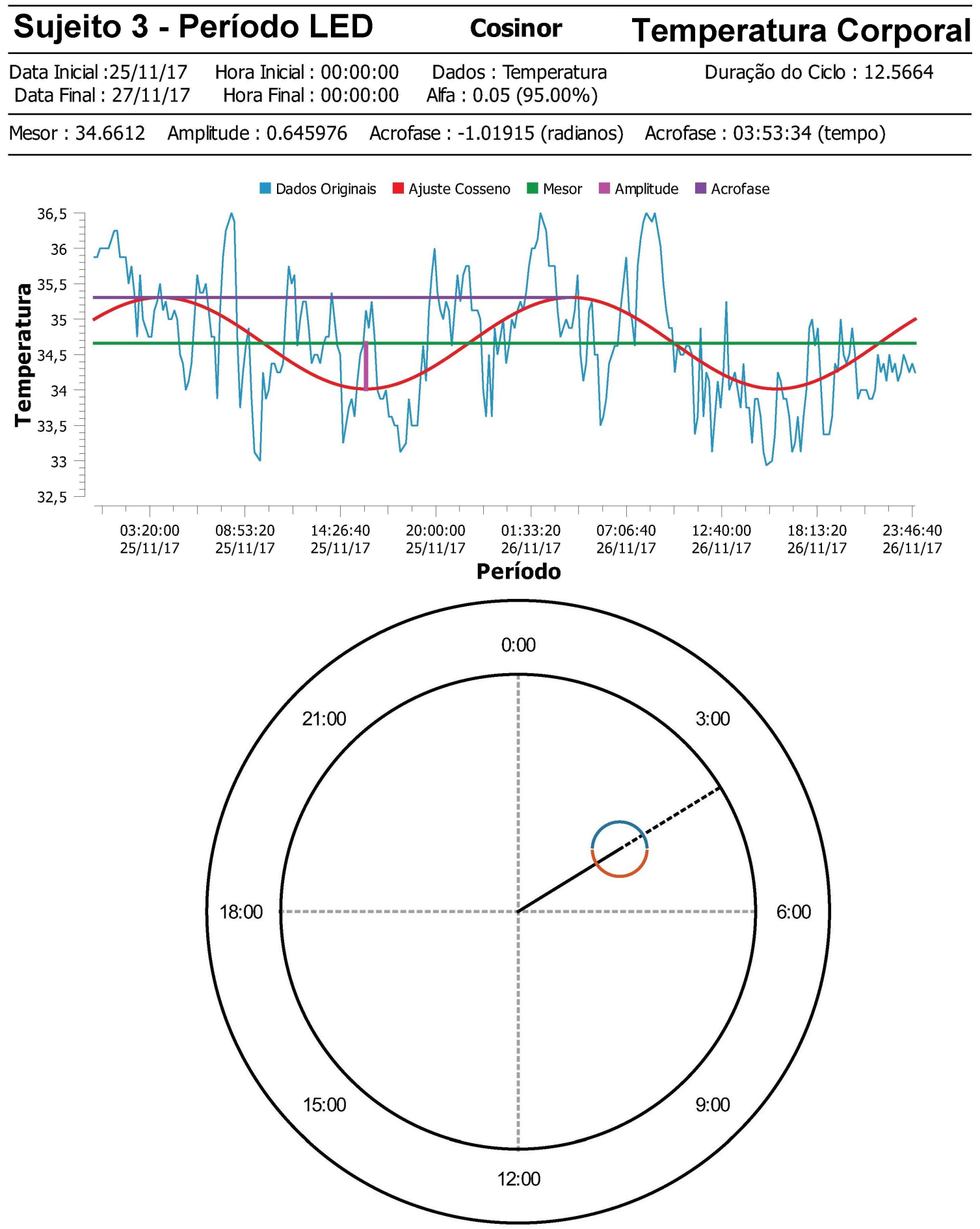




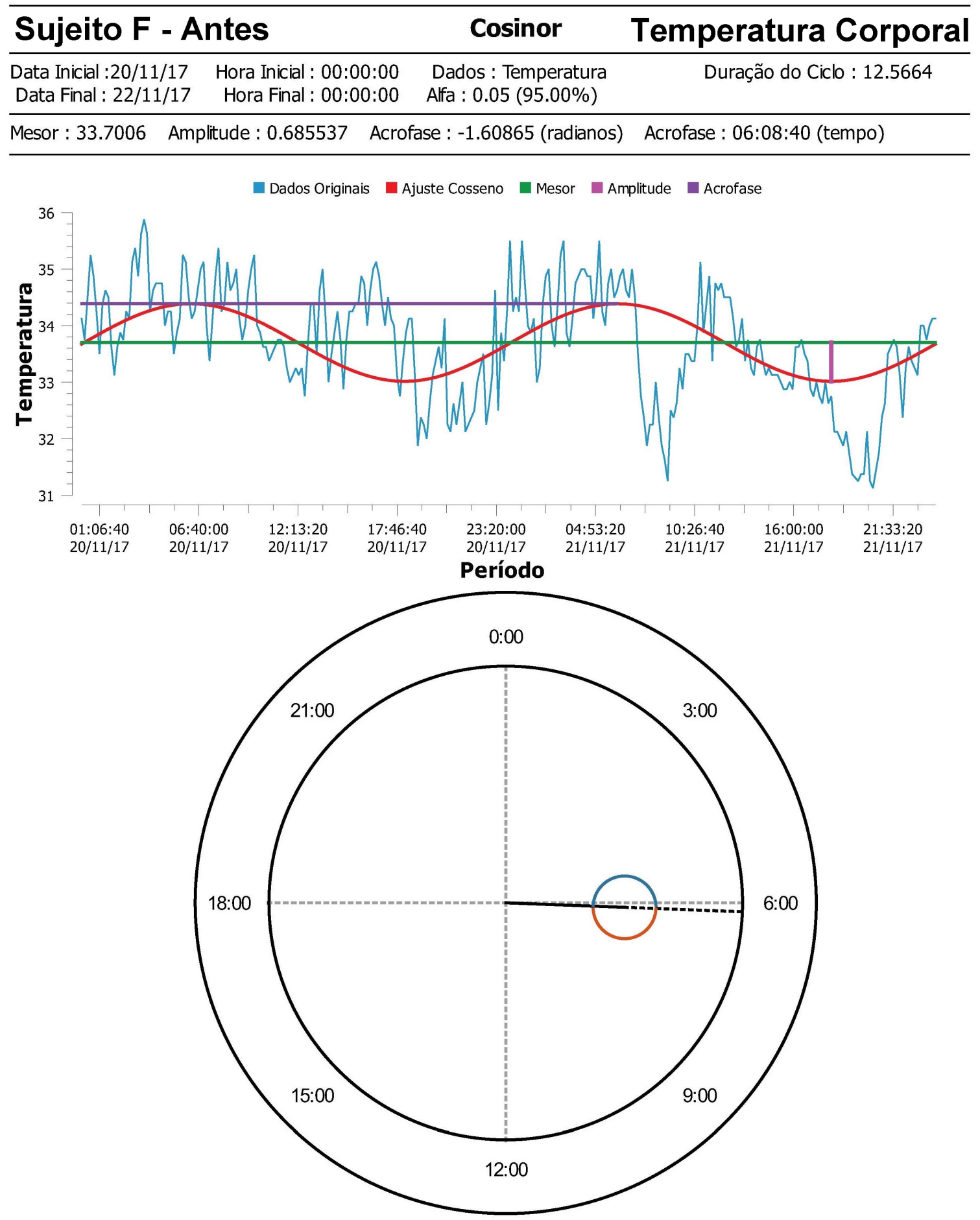




\section{Sujeito F - Período BB}

\section{Cosinor}

\section{Temperatura Corporal}

Data Inicial :23/11/17 Hora Inicial : 00:00:00 Dados : Temperatura

Duração do Ciclo : 12.5664

Data Final : 25/11/17 Hora Final : 00:00:00 Alfa : $0.05(95.00 \%)$

Mesor : 33.1703 Amplitude : 0.790162 Acrofase : -0.960419 (radianos) Acrofase : 03:40:06 (tempo)
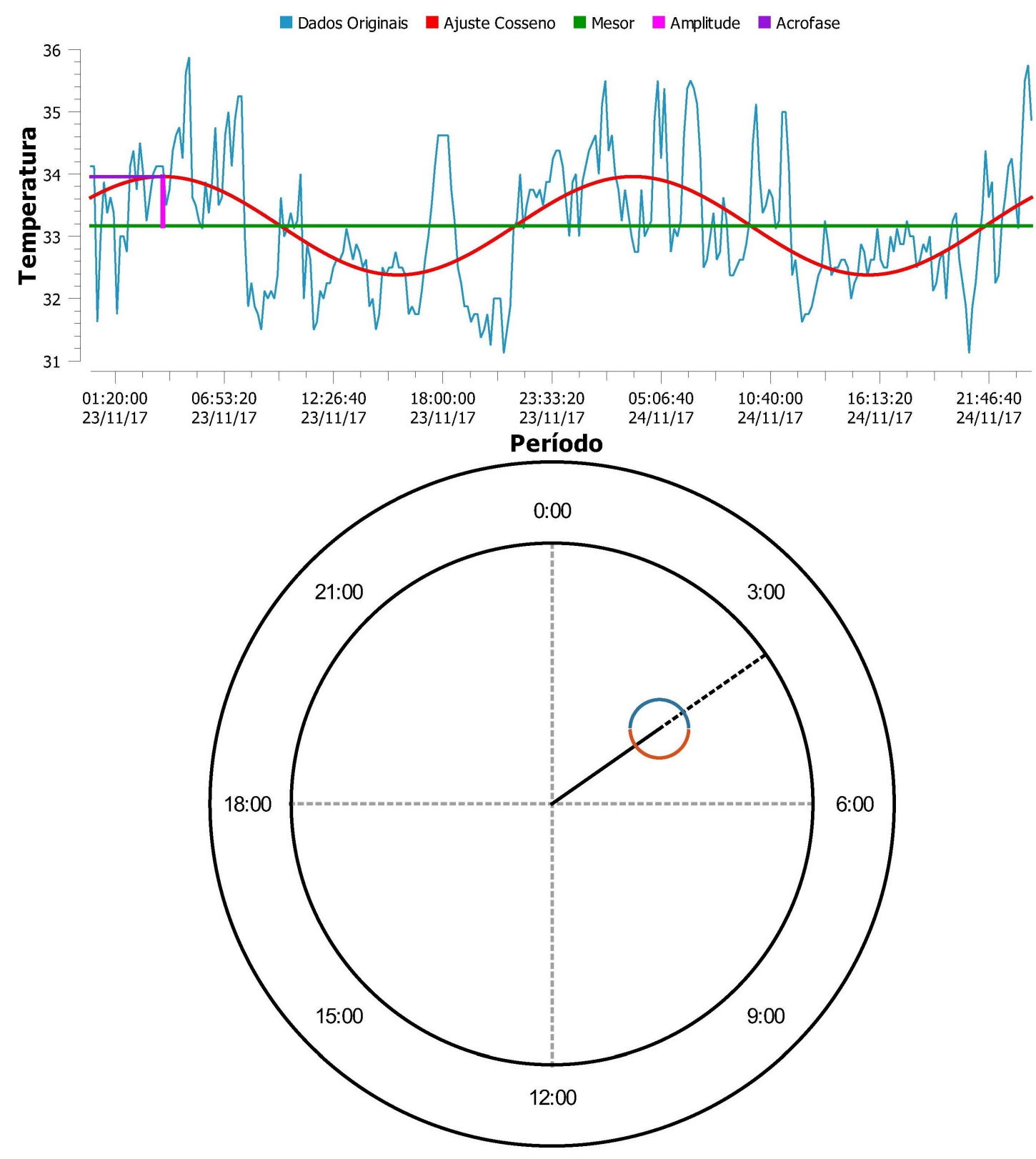


\section{Sujeito F - Período LED}

Cosinor

Temperatura Corporal

Data Inicial :26/11/17 Hora Inicial : 00:00:00 Dados : Temperatura

Duração do Ciclo : 12.5664 Data Final : $28 / 11 / 17$ Hora Final : 00:00:00 Alfa : $0.05(95.00 \%)$

Mesor : 33.7579 Amplitude : 0.621664 Acrofase : -1.86873 (radianos) Acrofase : 07:08:16 (tempo)
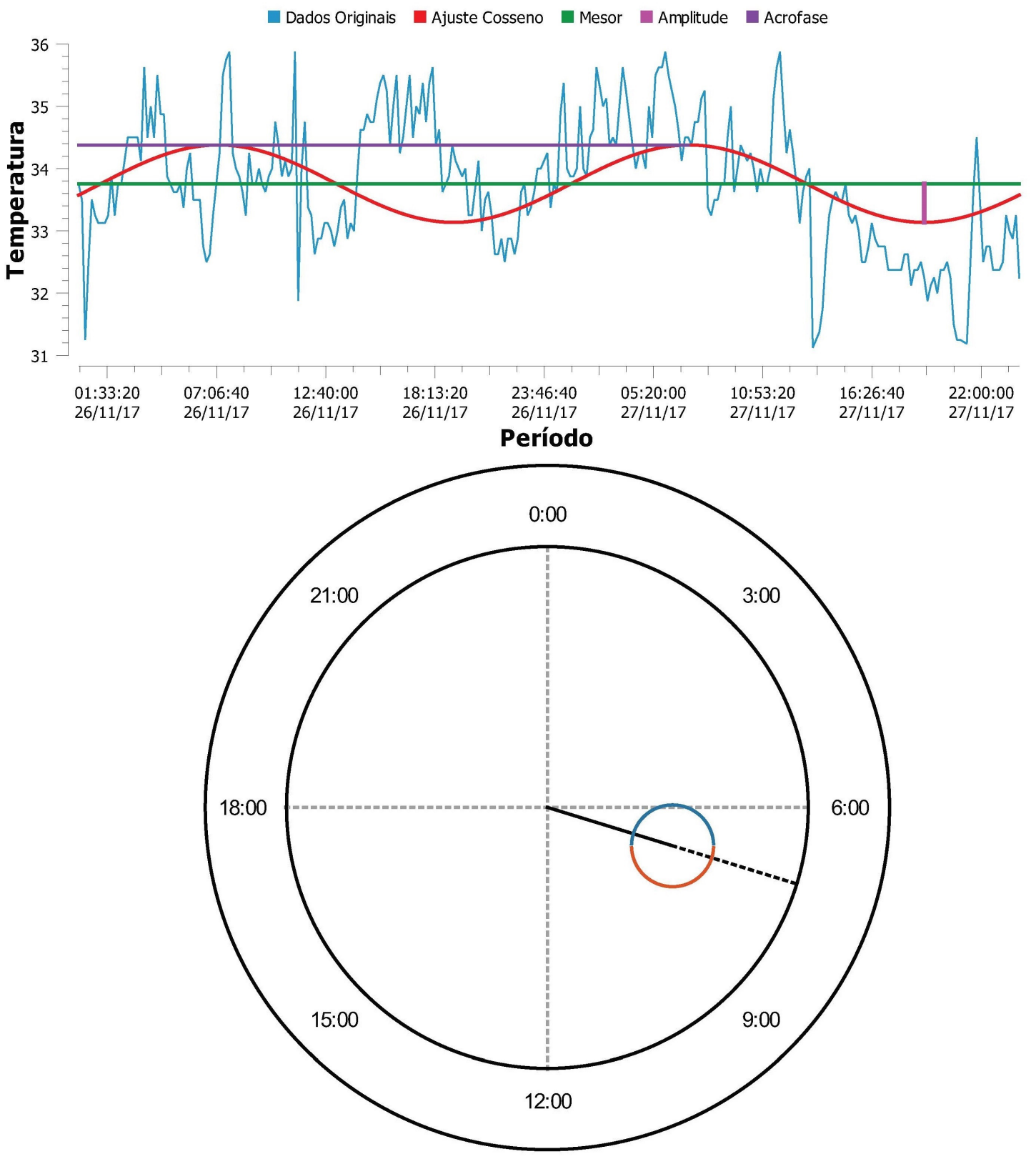


\section{Sujeito G - Antes}

Cosinor

Data Inicial :04/12/17 Hora Inicial : 00:00:00 Data Final : 06/12/17 Hora Final : 00:00:00
Temperatura Corporal

Duração do Ciclo : 12.5664 Alfa : 0.05 (95.00\%)

Mesor : 34.5786 Amplitude : 0.448165 Acrofase : -0.287068 (radianos) Acrofase : 01:05:47 (tempo)
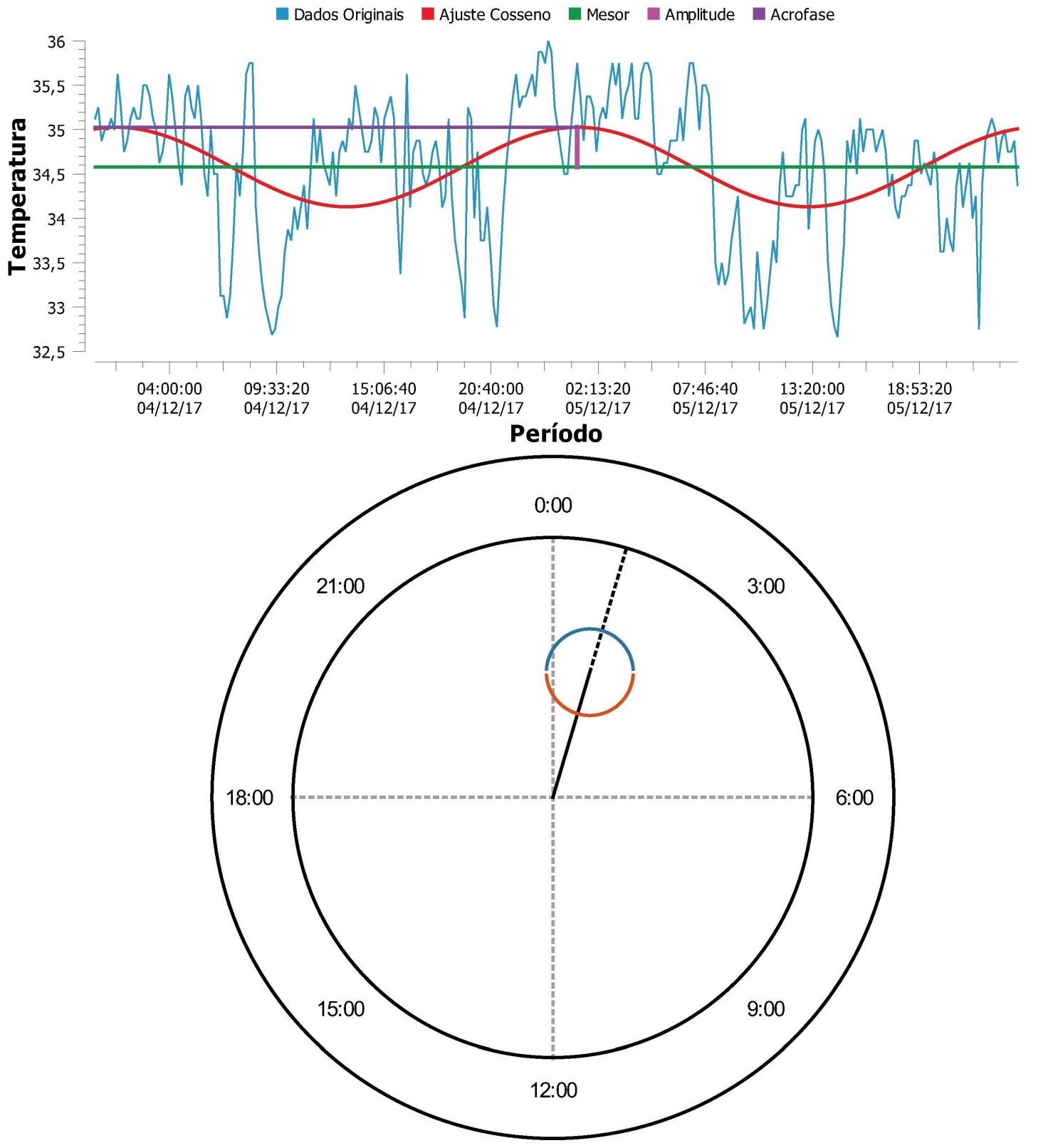


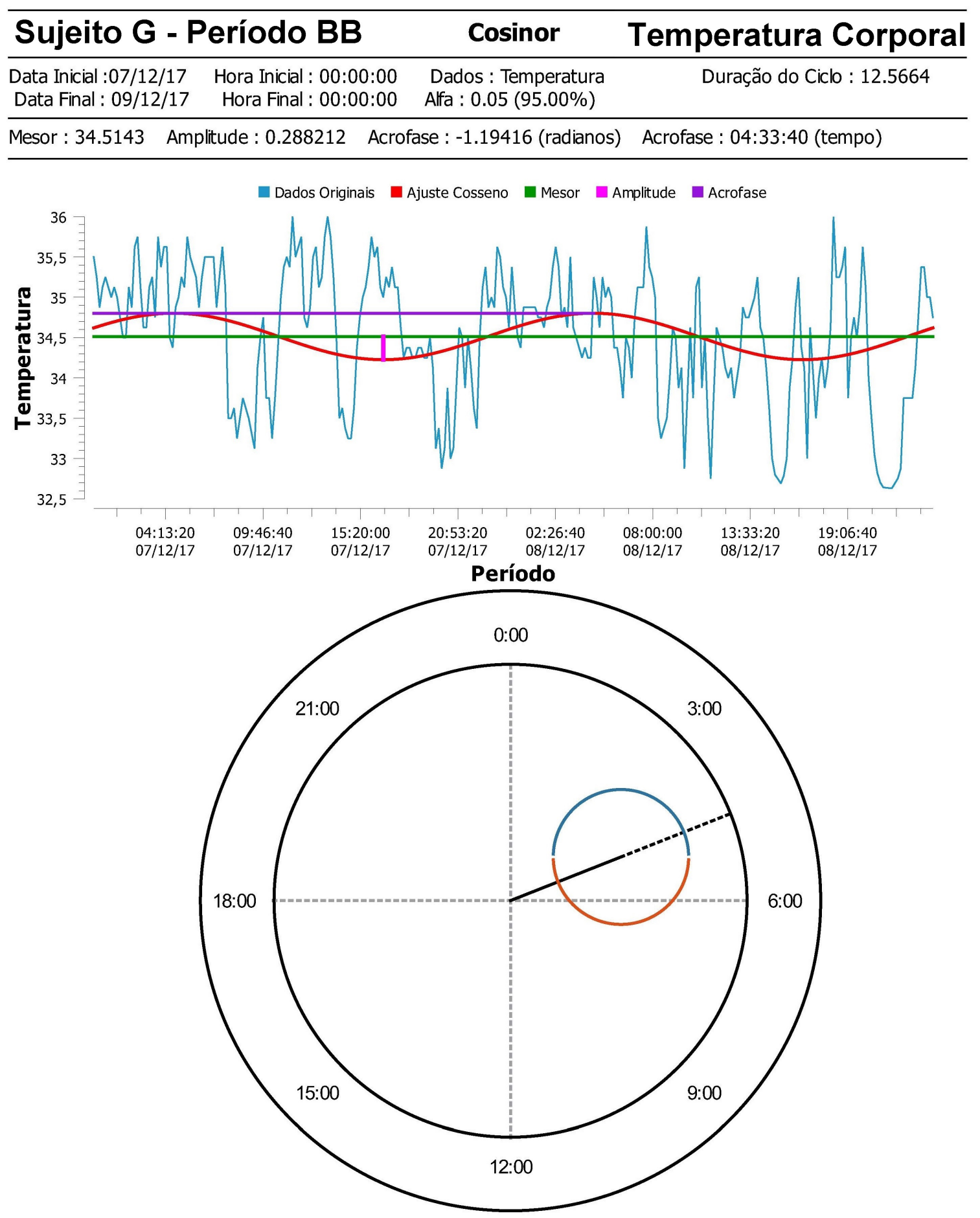




\begin{tabular}{lrcc}
\hline Sujeito G - Período LED & Cosinor & Temperatura Corporal \\
\hline Data Inicial :10/12/17 & Hora Inicial : 00:00:00 & Dados : Temperatura & Duração do Ciclo : 18.8496 \\
Data Final : $13 / 12 / 17$ & Hora Final : 00:00:00 & Alfa : $0.05(95.00 \%)$ & \\
\hline
\end{tabular}

Mesor : 34.4404 Amplitude : 0.336208 Acrofase : -0.620181 (radianos) Acrofase : 02:22:08 (tempo)

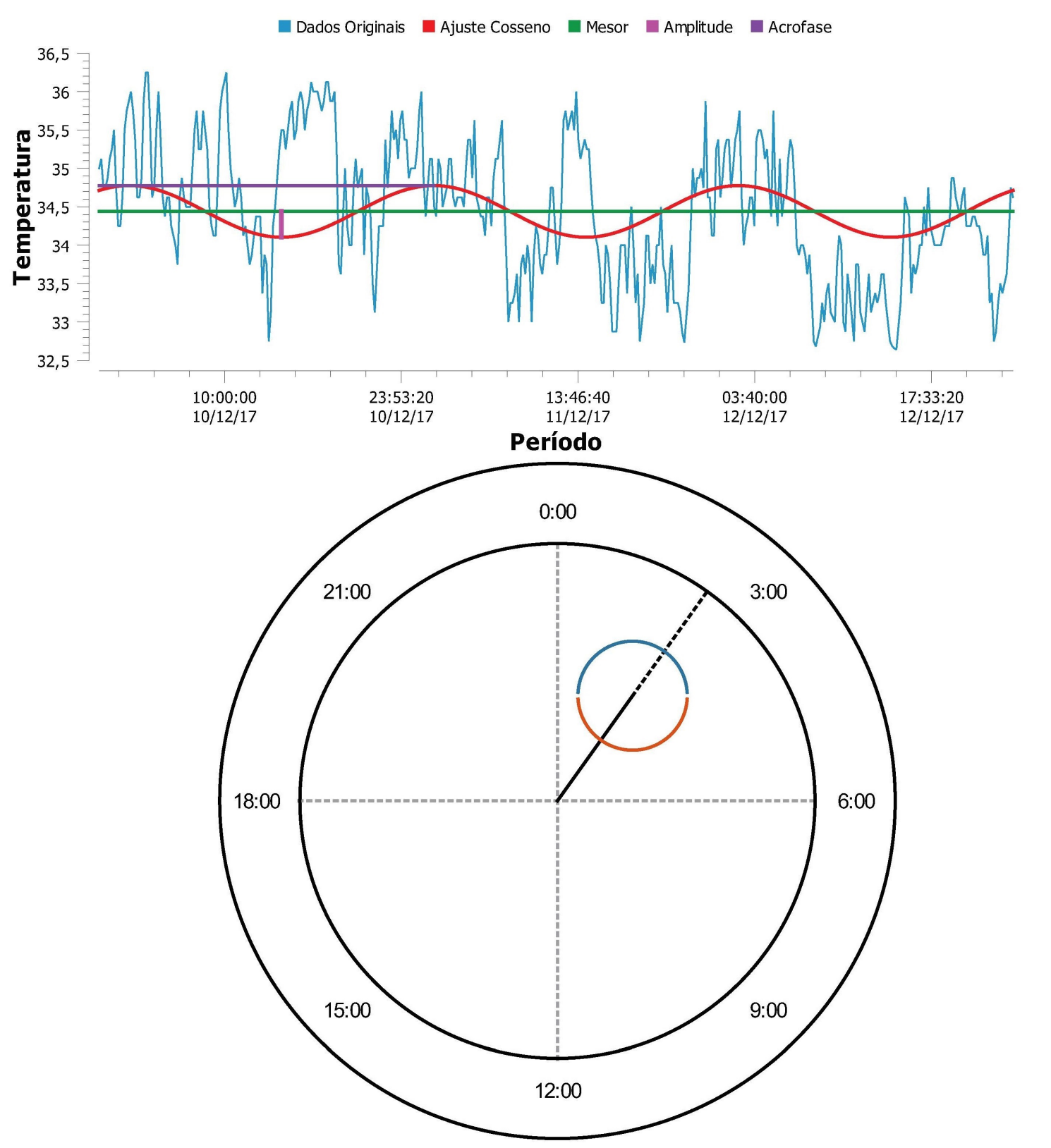




\section{Sujeito H - Antes}

\section{Cosinor}

Temperatura Corporal

Data Inicial :03/12/17 Hora Inicial : 00:00:00 Dados : Temperatura Data Final : 05/12/17 Hora Final : 00:00:00 Alfa : $0.05(95.00 \%)$

Duração do Ciclo : 12.5664

Mesor : 34.201 Amplitude : 0.632577 Acrofase : -0.495088 (radianos) Acrofase : 01:53:27 (tempo)
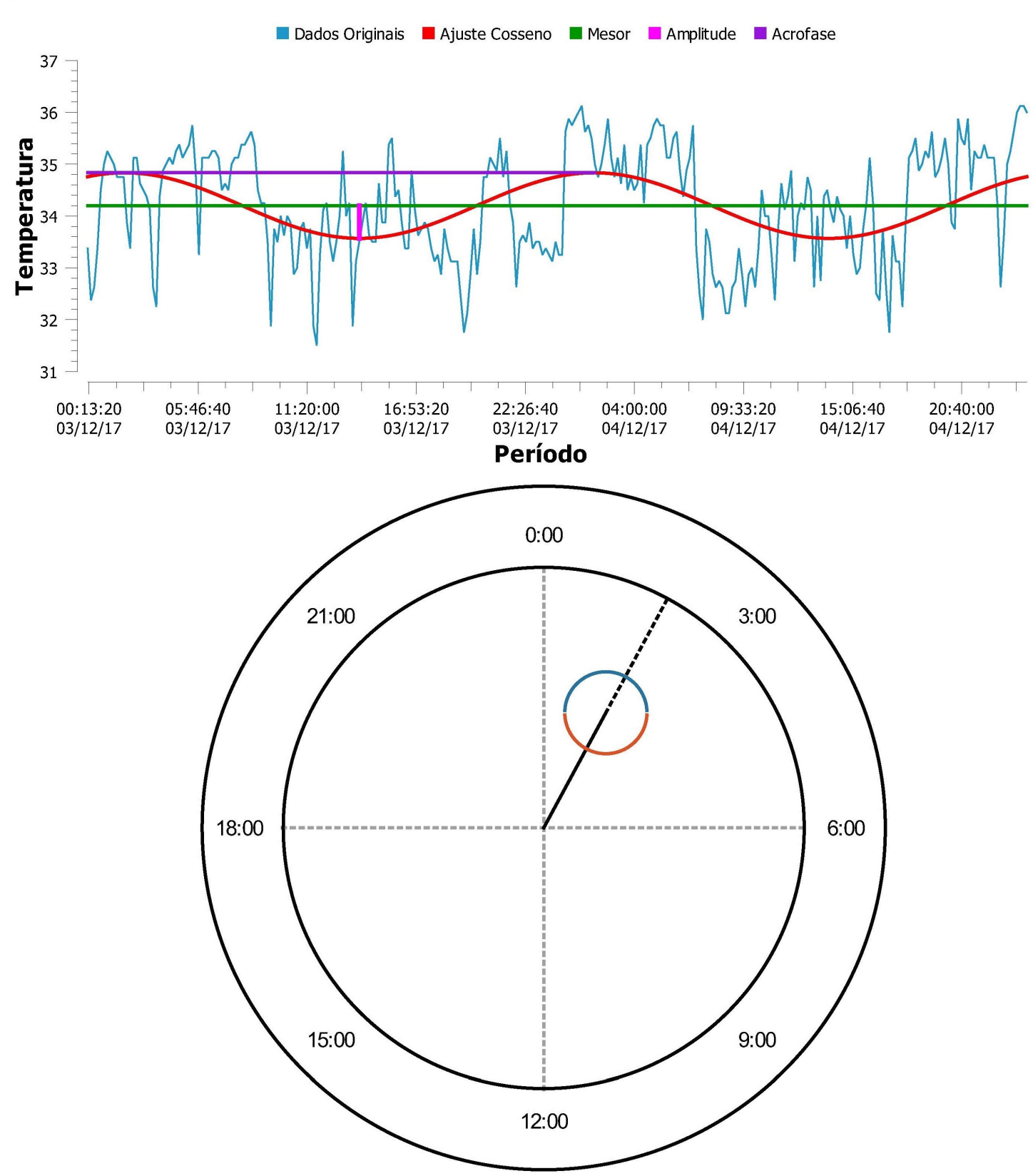


\section{Sujeito H - Período BB}

\section{Cosinor}

Temperatura Corporal

Data Inicial :06/12/17 Hora Inicial : 00:00:00 Dados : Temperatura

Duração do Ciclo : 12.5664

Data Final : 08/12/17 Hora Final : 00:00:00 Alfa : $0.05(95.00 \%)$

Mesor : 34.1266 Amplitude : 1.11945 Acrofase : -0.483899 (radianos) Acrofase : 01:50:54 (tempo)
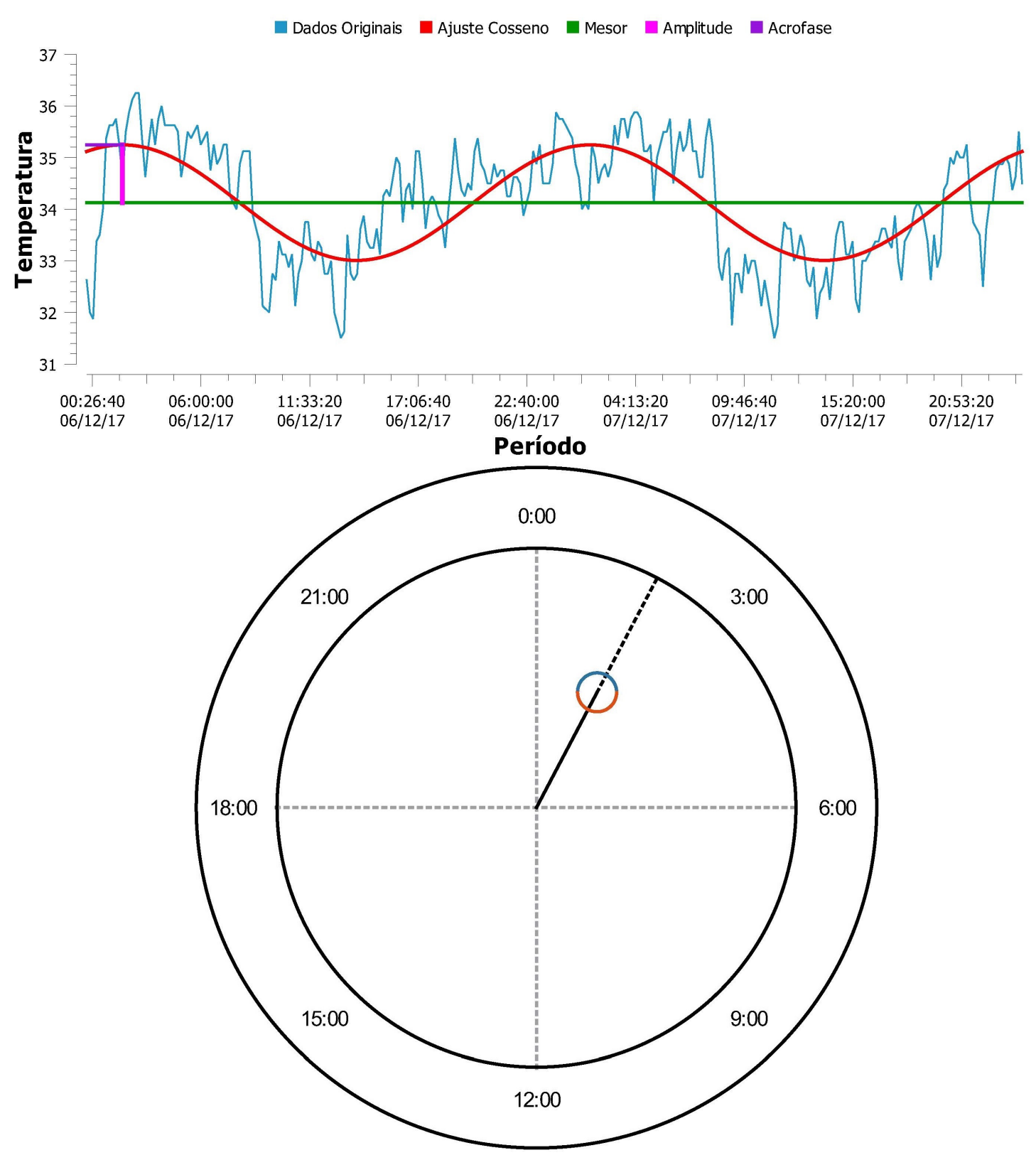


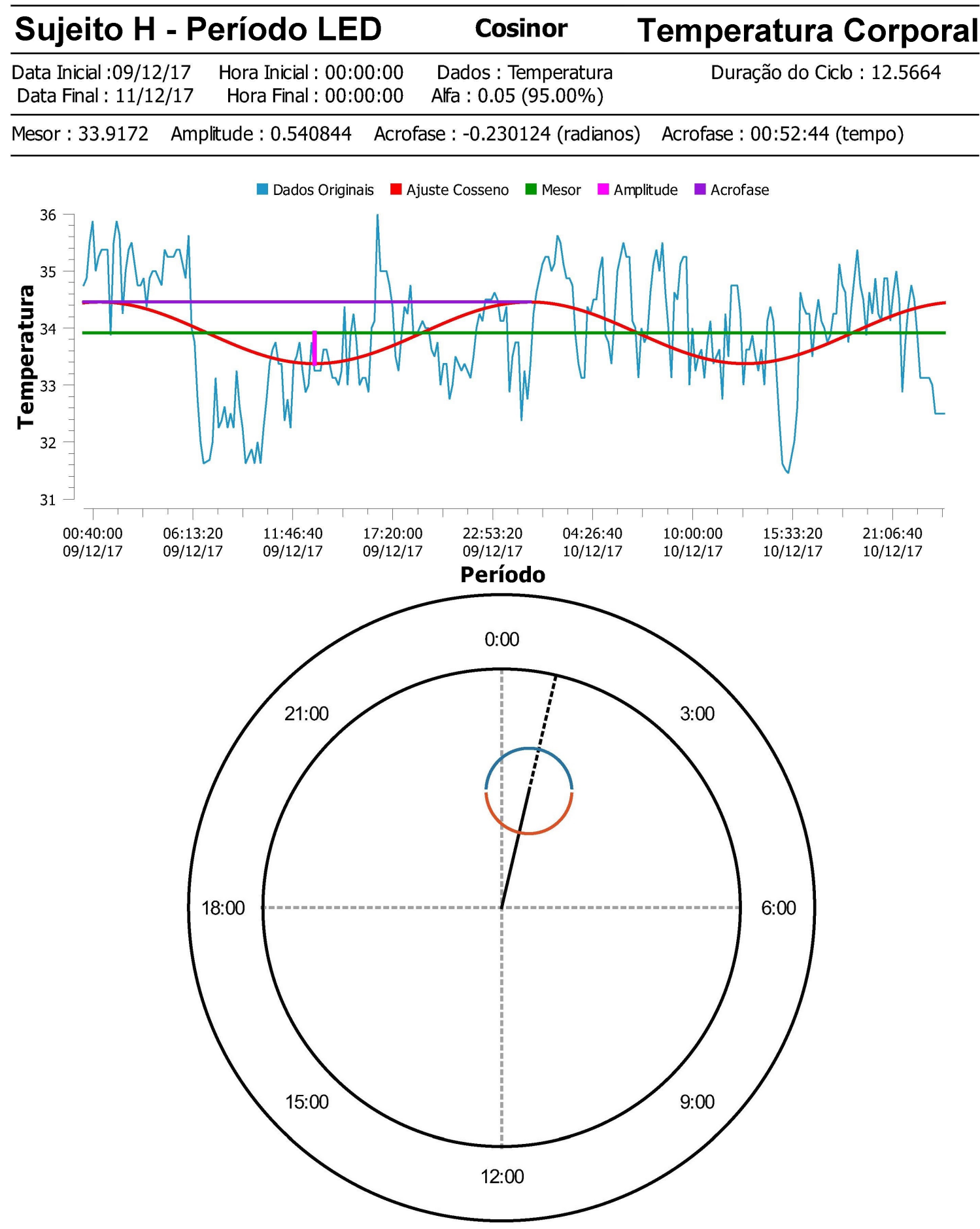




\section{Sujeito I - Antes}

Cosinor

Temperatura Corporal

Data Inicial :04/12/17 Hora Inicial : 00:00:00 Dados : Temperatura

Duração do Ciclo : 12.5664

Data Final : 06/12/17

Hora Final : 00:00:00

Alfa : $0.05(95.00 \%)$

Mesor : 34.8847 Amplitude : 0.285744 Acrofase : -0.622375 (radianos) Acrofase : 02:22:38 (tempo)

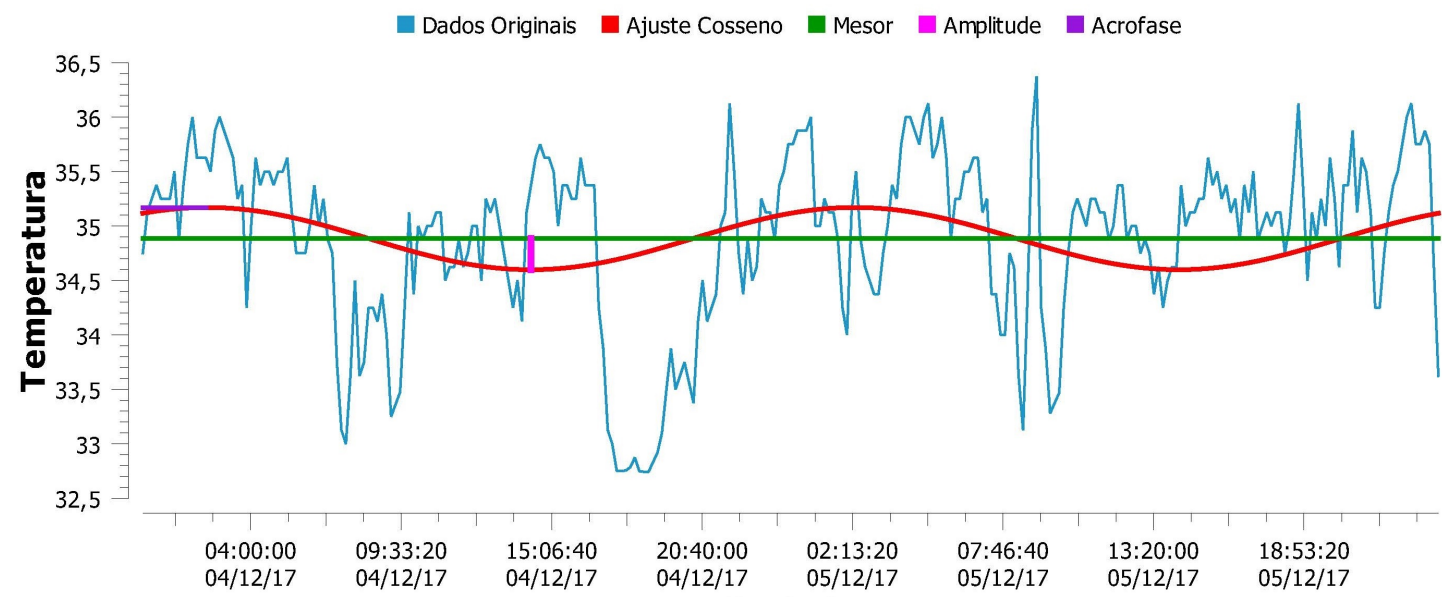

$04 / 12 / 17$

$04 / 12 / 17$

Período

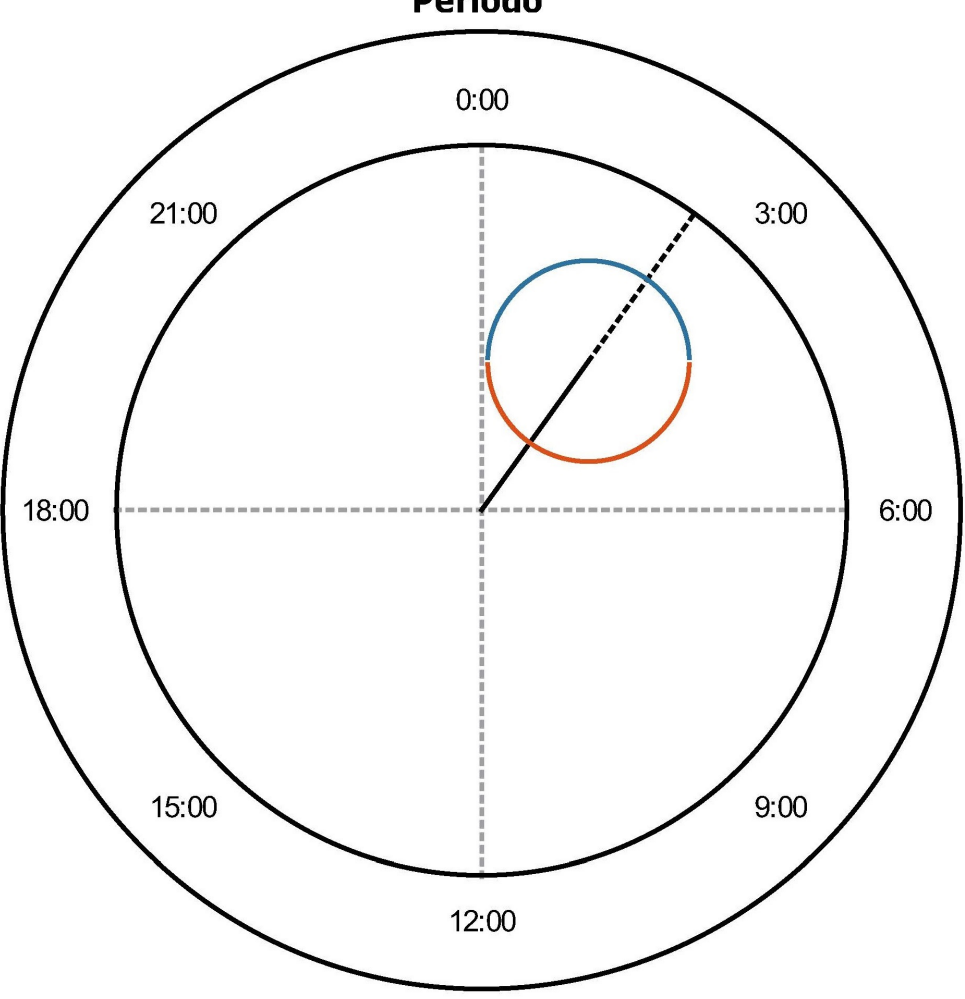




\section{Sujeito I - Período BB}

\section{Cosinor}

\section{Temperatura Corporal}

Data Inicial :07/12/17 Hora Inicial : 00:00:00 Dados : Temperatura Data Final : 09/12/17 Hora Final : 00:00:00 Alfa : $0.05(95.00 \%)$

Mesor : 35.0155 Amplitude : 0.599286 Acrofase :-0.152078 (radianos) Acrofase : 00:34:51 (tempo)

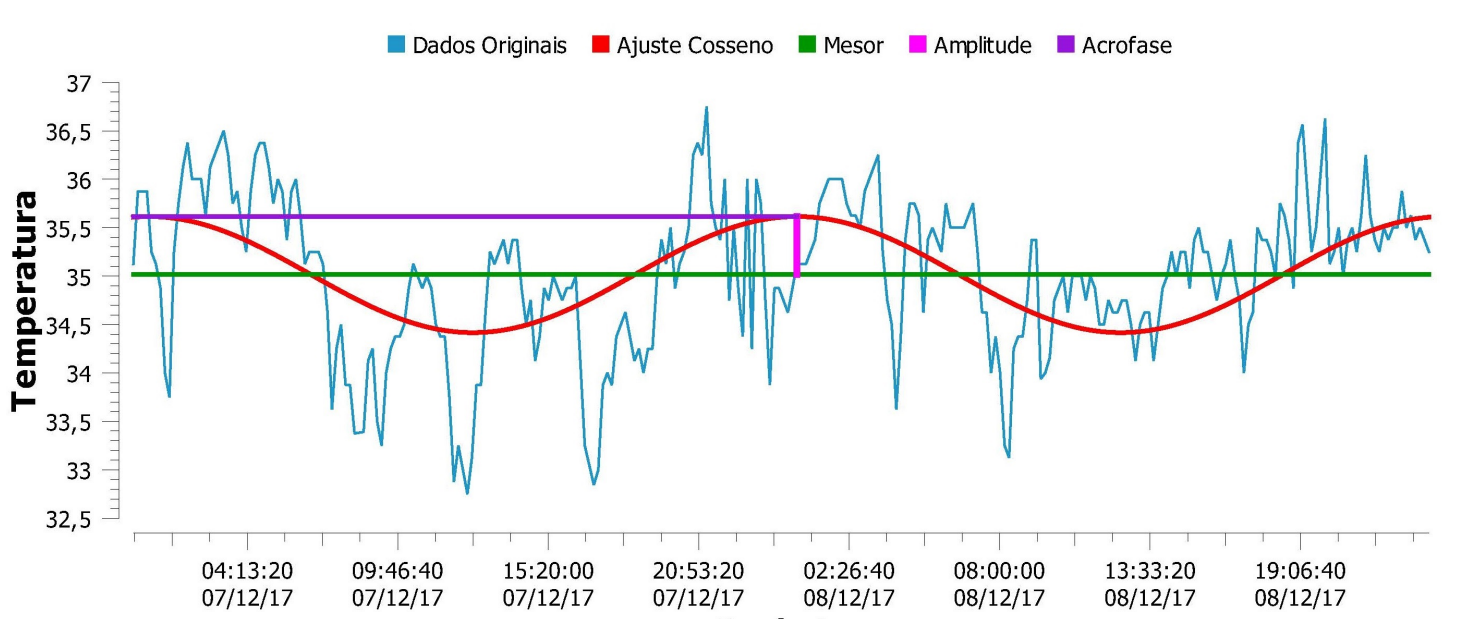

$$
07 / 12 / 17
$$
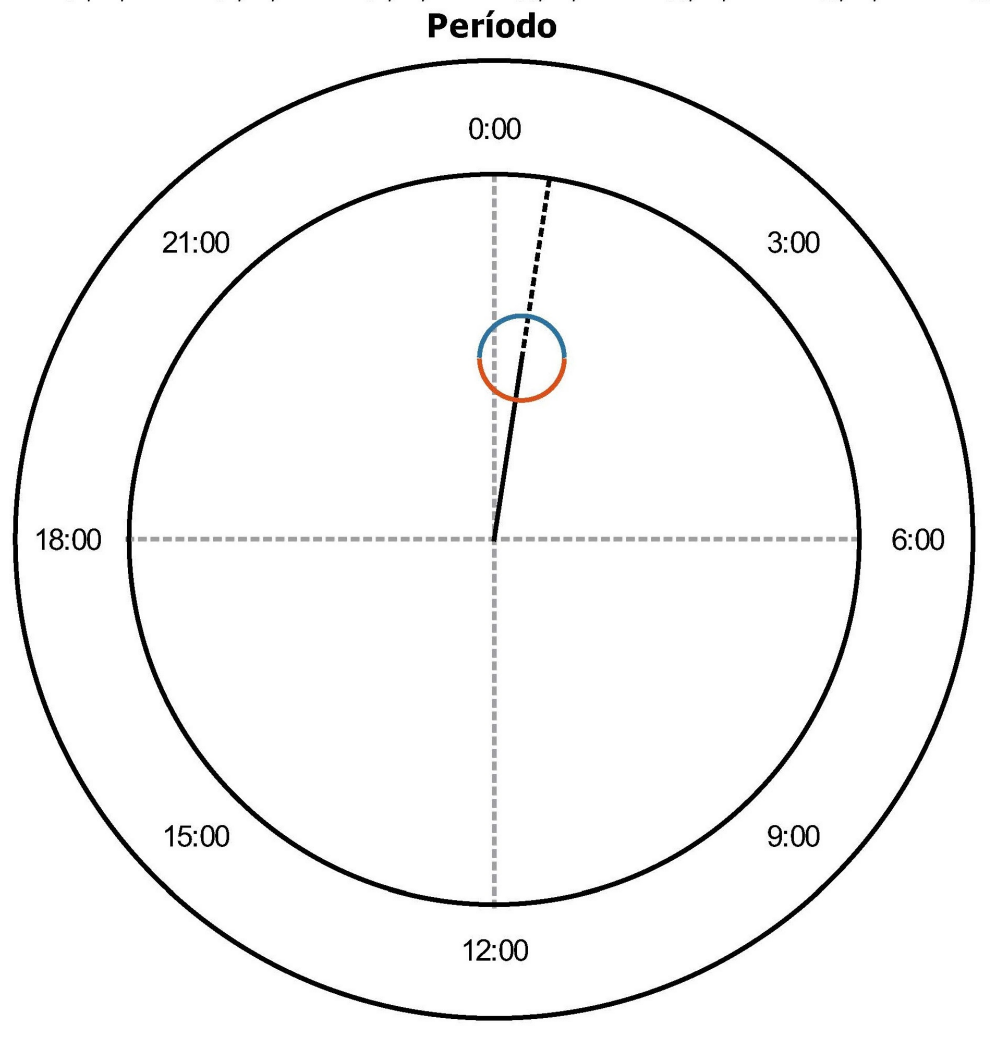


\begin{tabular}{|c|c|c|c|}
\hline \multicolumn{2}{|c|}{ Sujeito I - Período LED } & \multirow{2}{*}{$\begin{array}{c}\text { Cosinor } \\
\text { Dados : Temperatura } \\
\text { Alfa : } 0.05(95.00 \%)\end{array}$} & \multirow{2}{*}{$\frac{\text { Temperatura Corporal }}{\text { Duração do Ciclo : } 12.5664}$} \\
\hline $\begin{array}{l}\text { Data Inicial : } 10 / 12 / 1 \\
\text { Data Final : } 12 / 12 / 1\end{array}$ & $\begin{array}{r}\text { Hora Inicial : 00:00:00 } \\
\text { Hora Final : 00:00:00 }\end{array}$ & & \\
\hline Mesor : 34.5897 & litude : 0.448897 & ase : -1.14814 (radianos) & Acrofase : 04:23:08 (tempo) \\
\hline
\end{tabular}

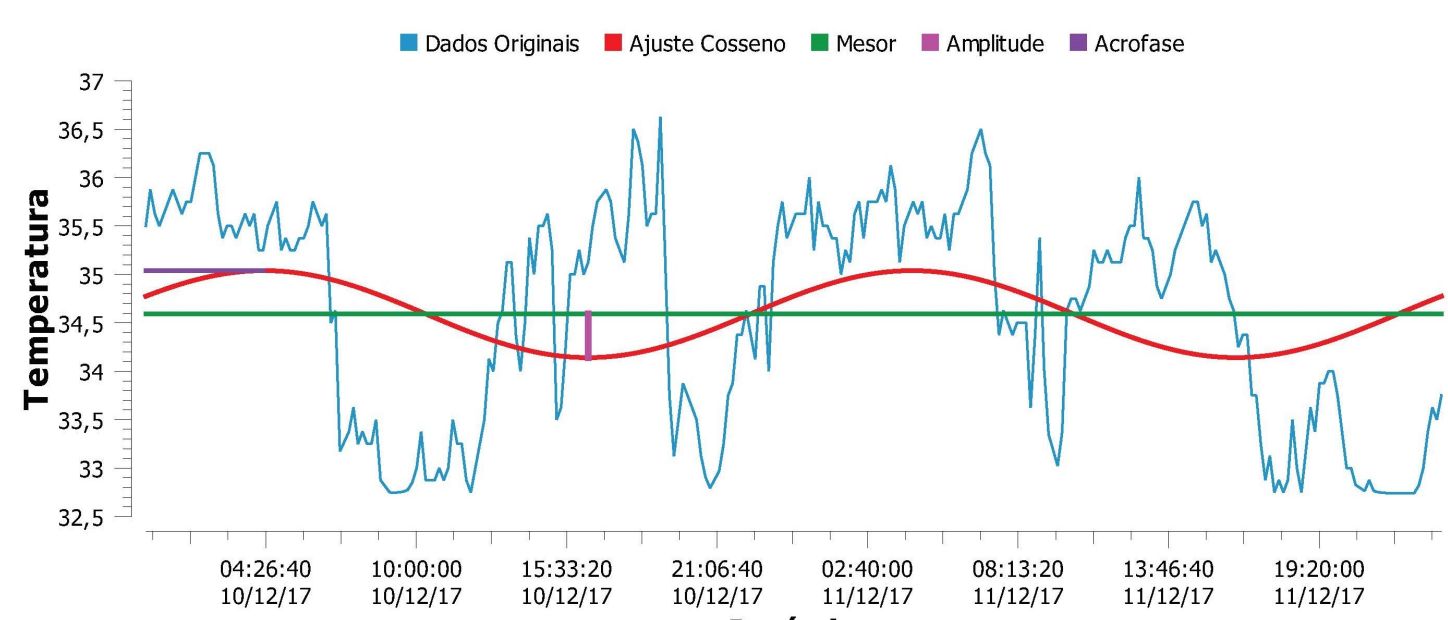

$10 / 12 / 1$

Período

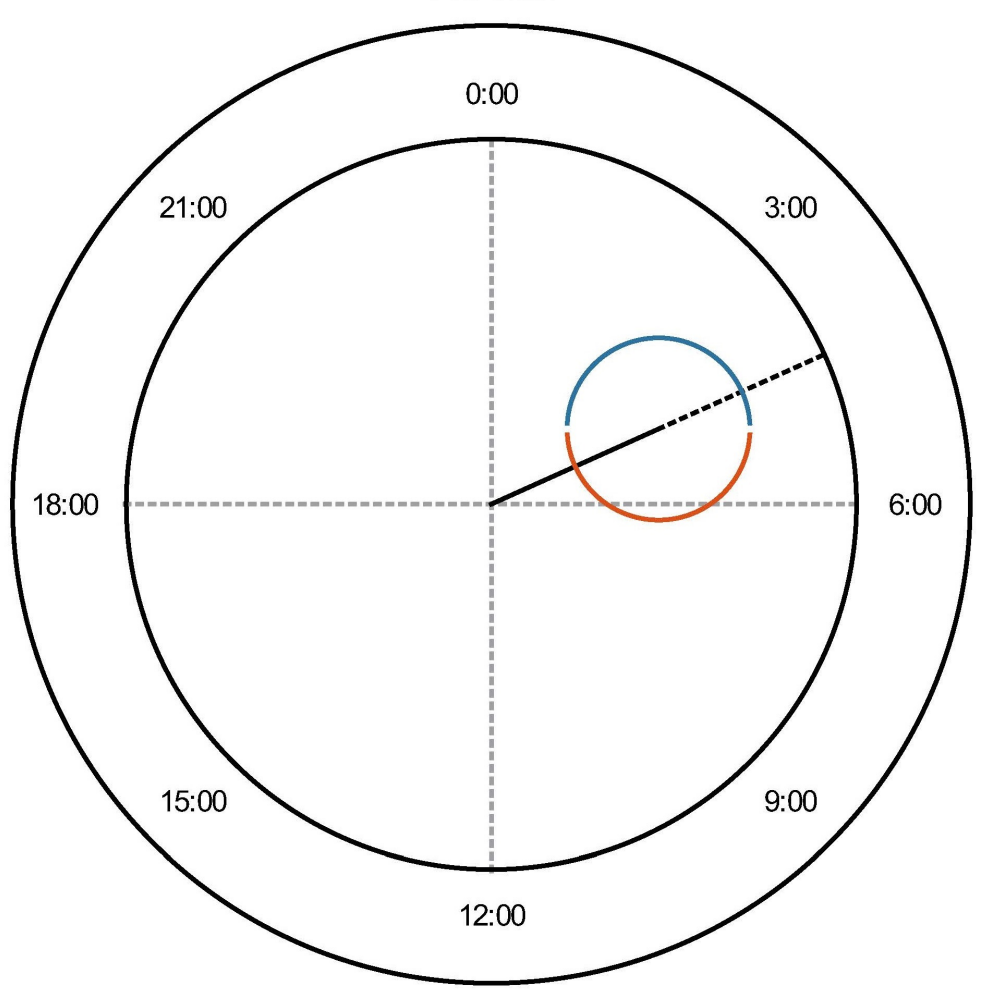




\section{APÊNDICE D - Análise fotográfica - Luminâncias}

Ambientes cujos usuários apresentaram alteração hormonal em consequência da exposição noturna à luz de LEDs:
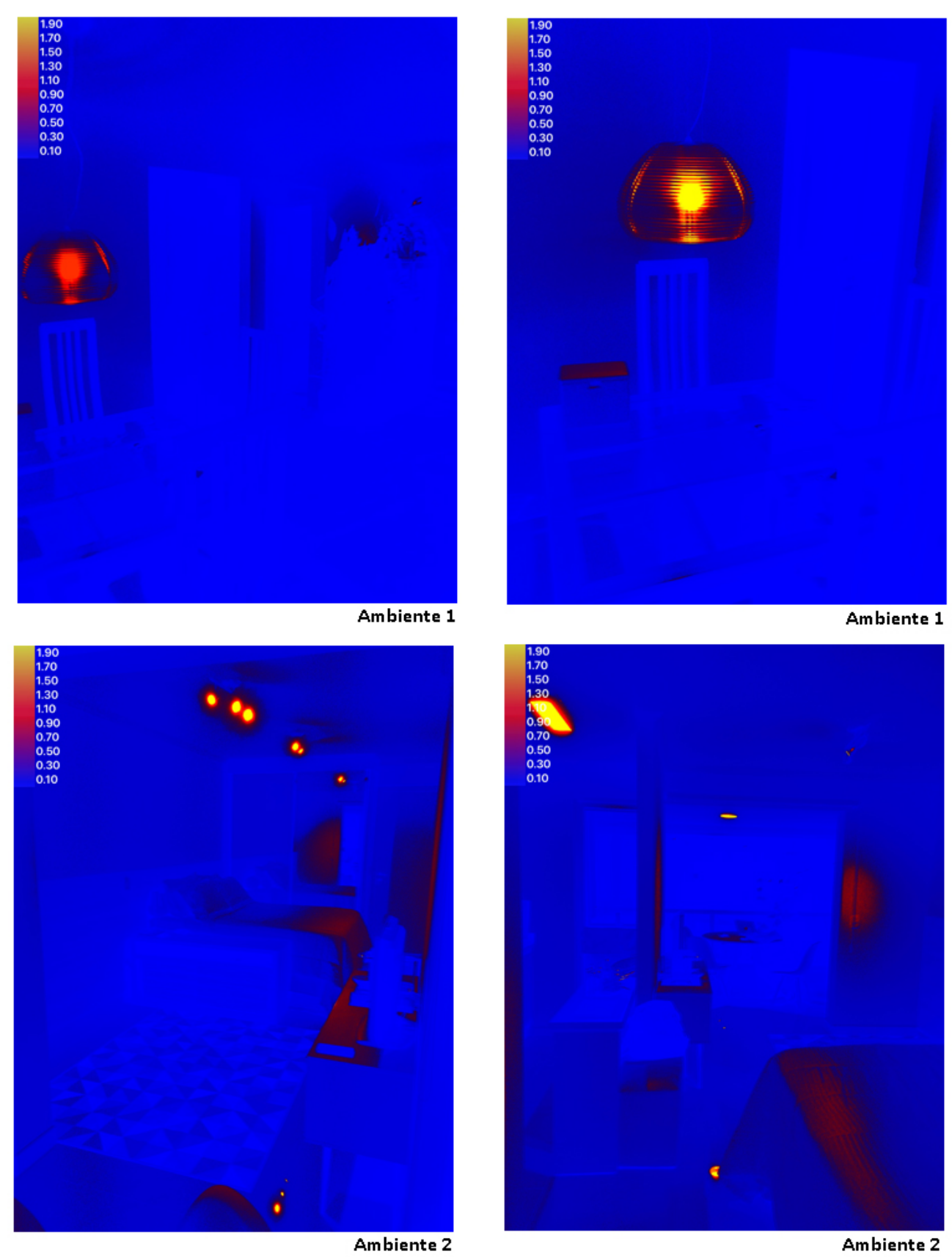

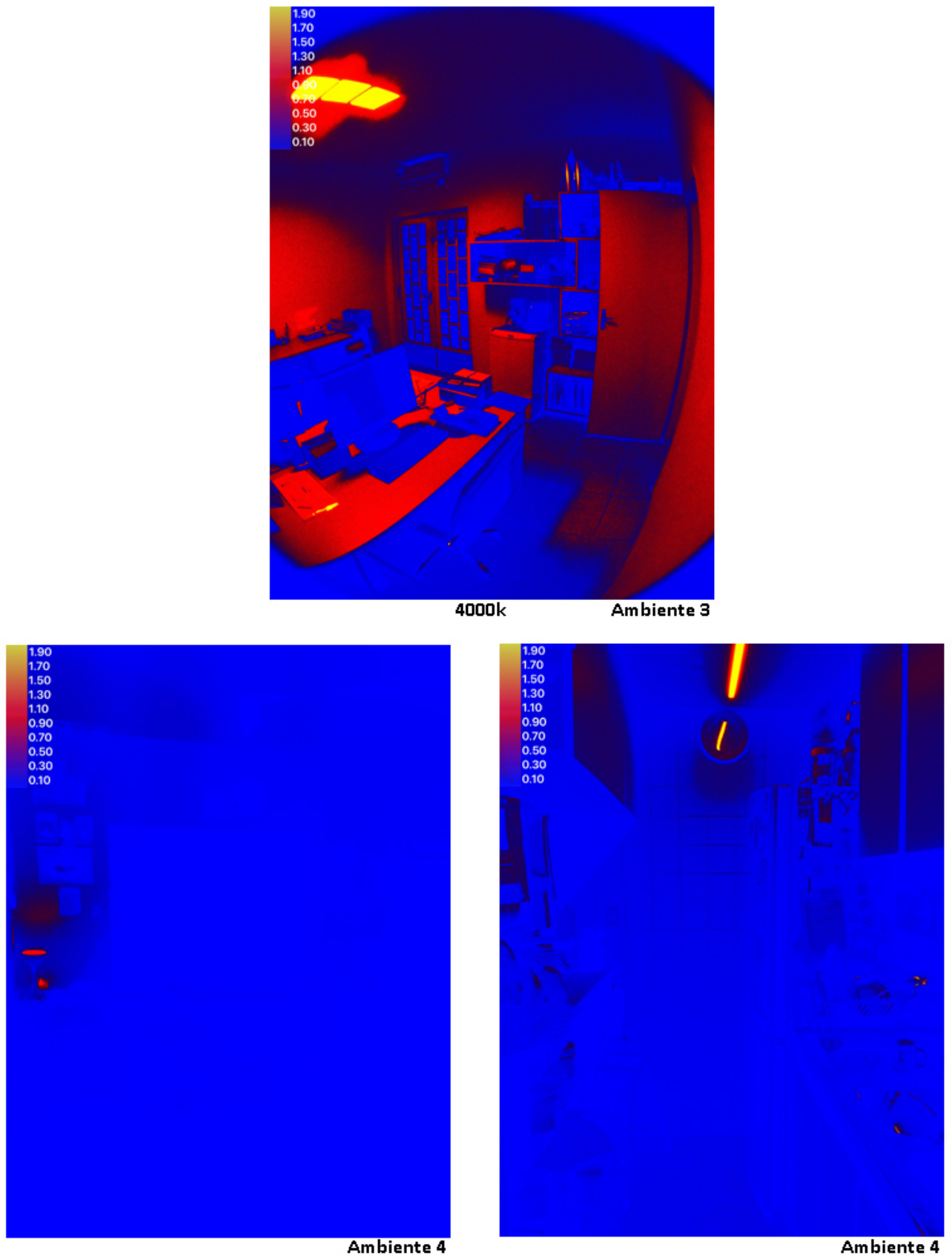

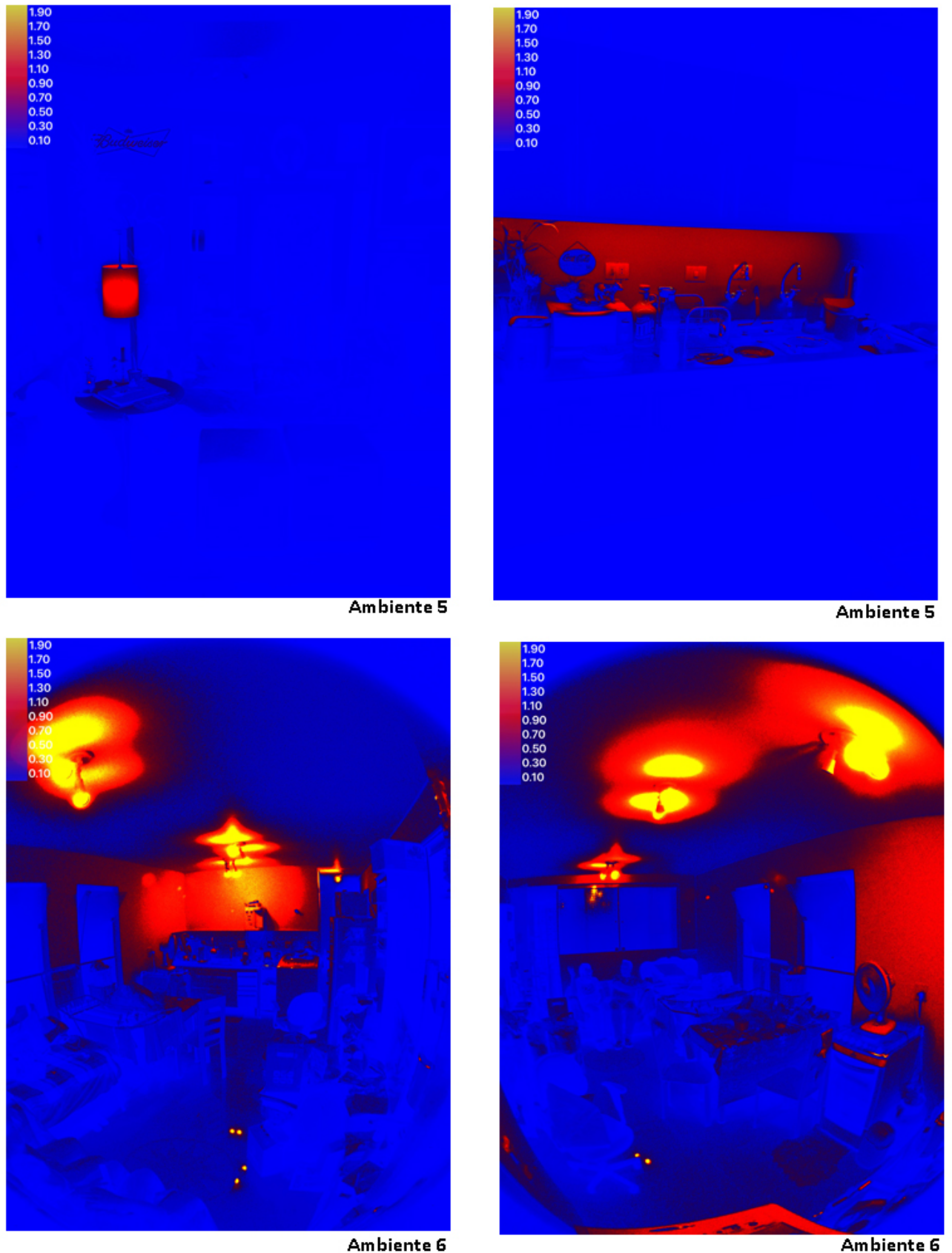


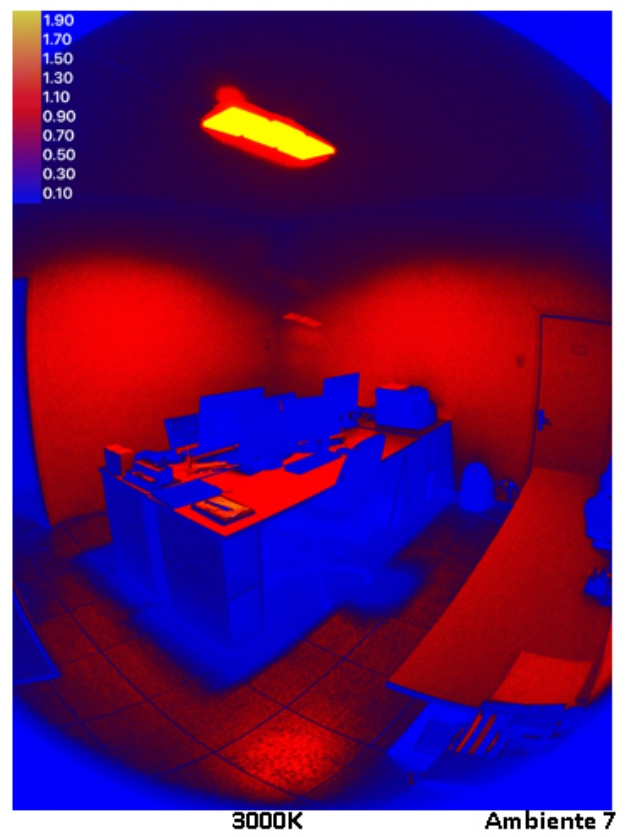


APÊNDICE D. Análise fotográfica-Luminâncias

118

Ambientes cujos usuários não apresentaram alteração hormonal em consequência da exposição noturna à luz de LEDs:
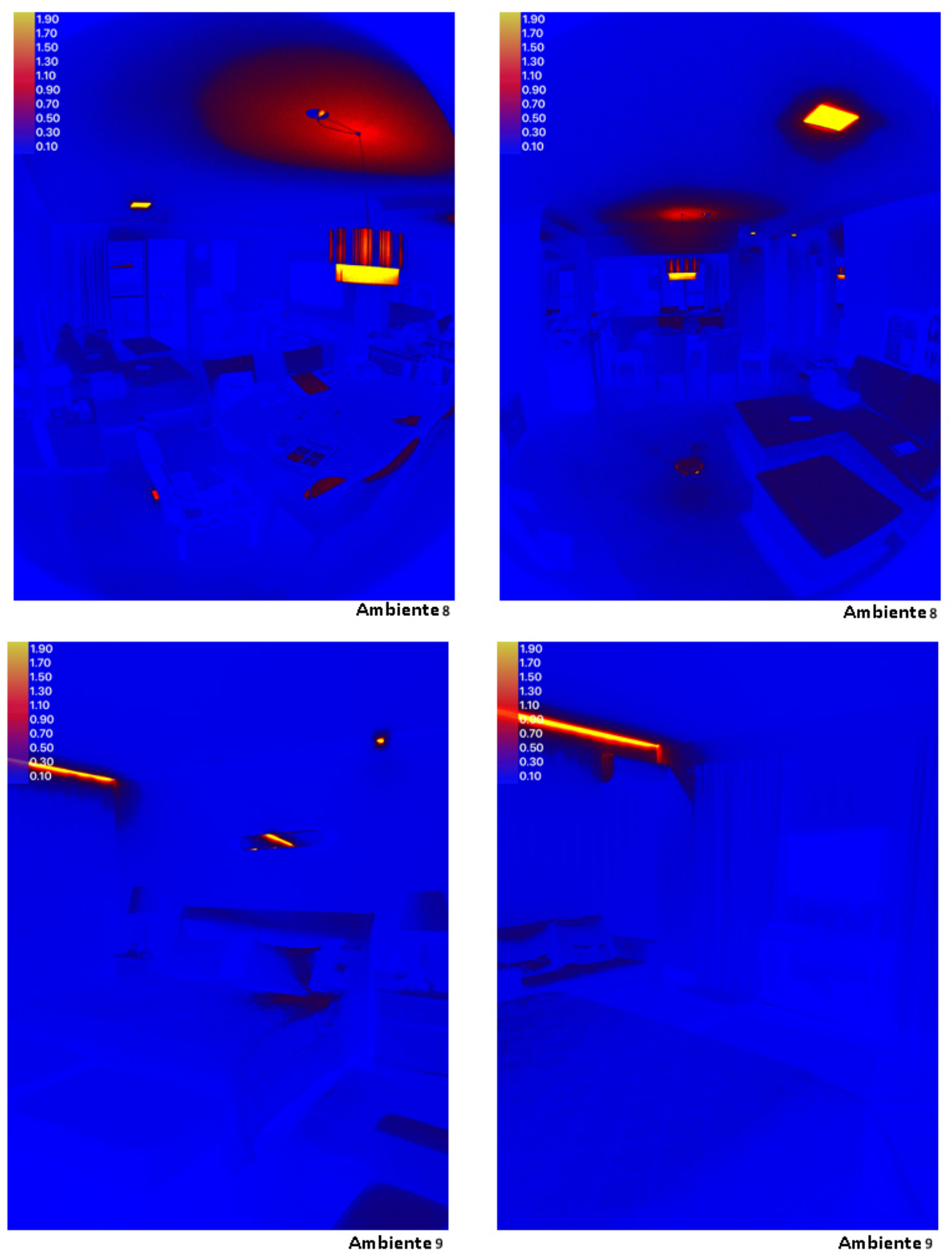

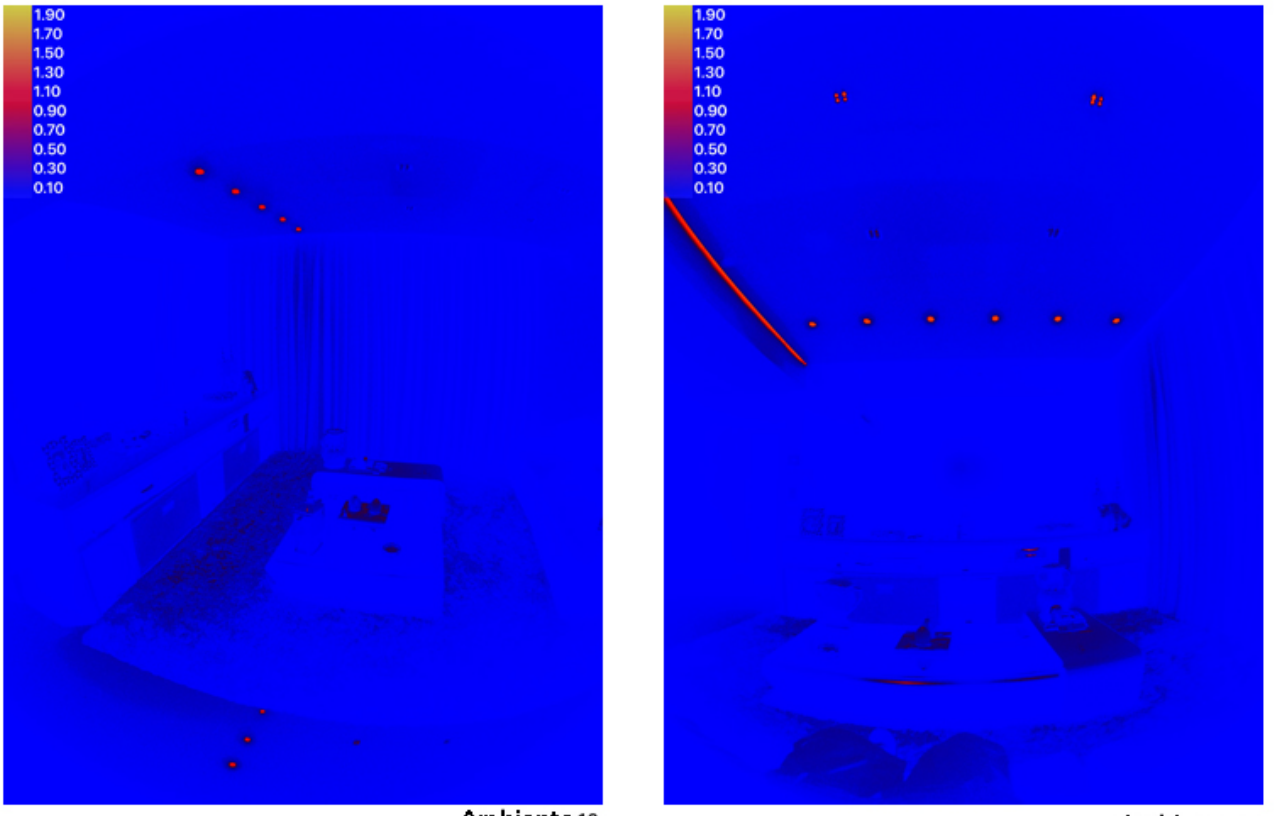


\section{APÊNDICE E - Análise fotográfica - Luz azul}

Ambientes cujos usuários apresentaram alteração hormonal em consequência da exposição noturna à luz de LEDs:

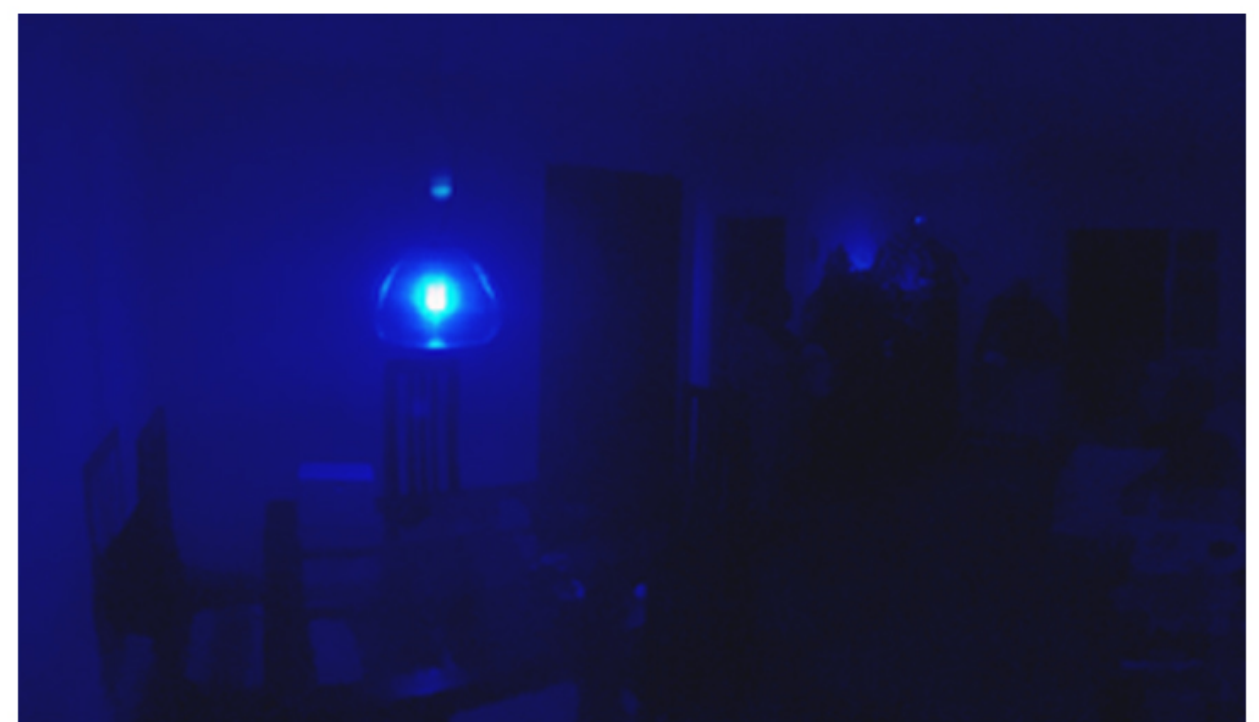

Ambiente 1
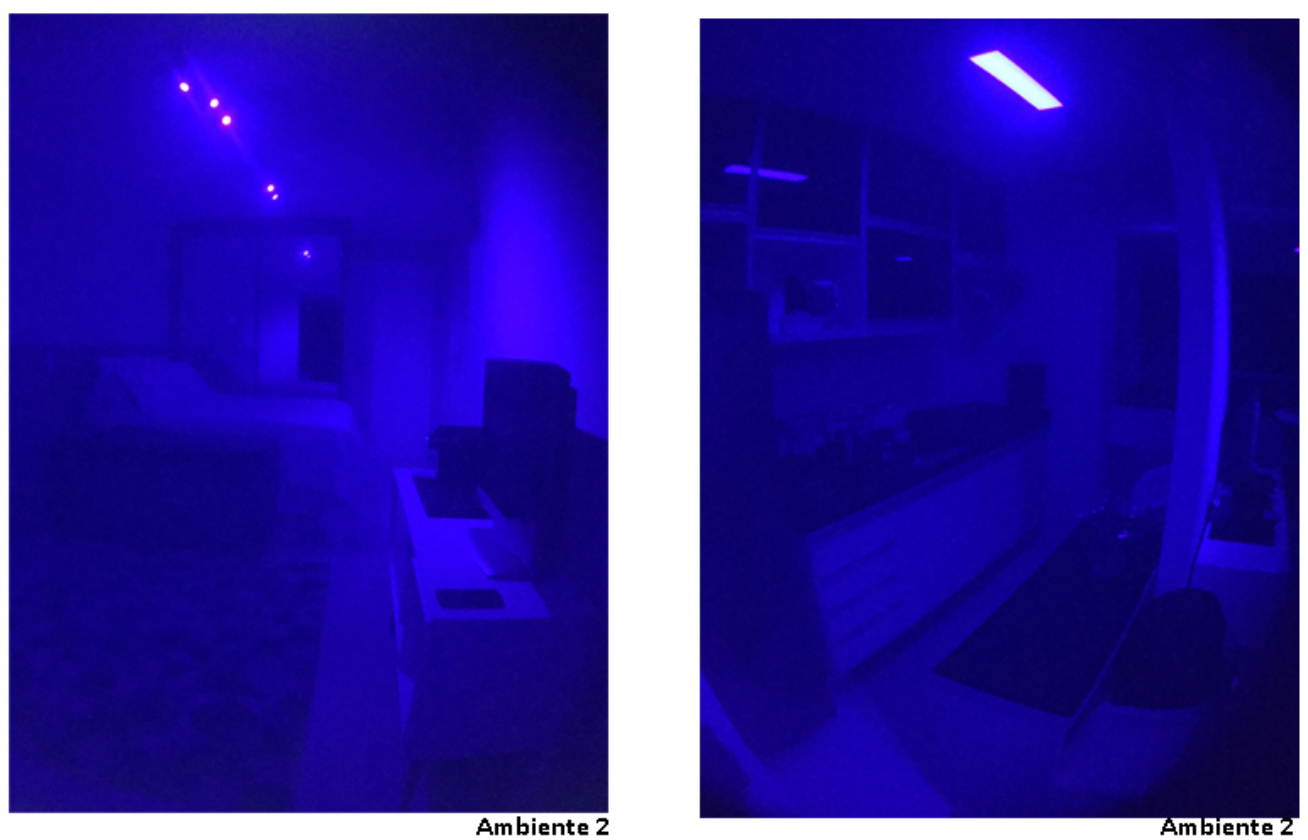

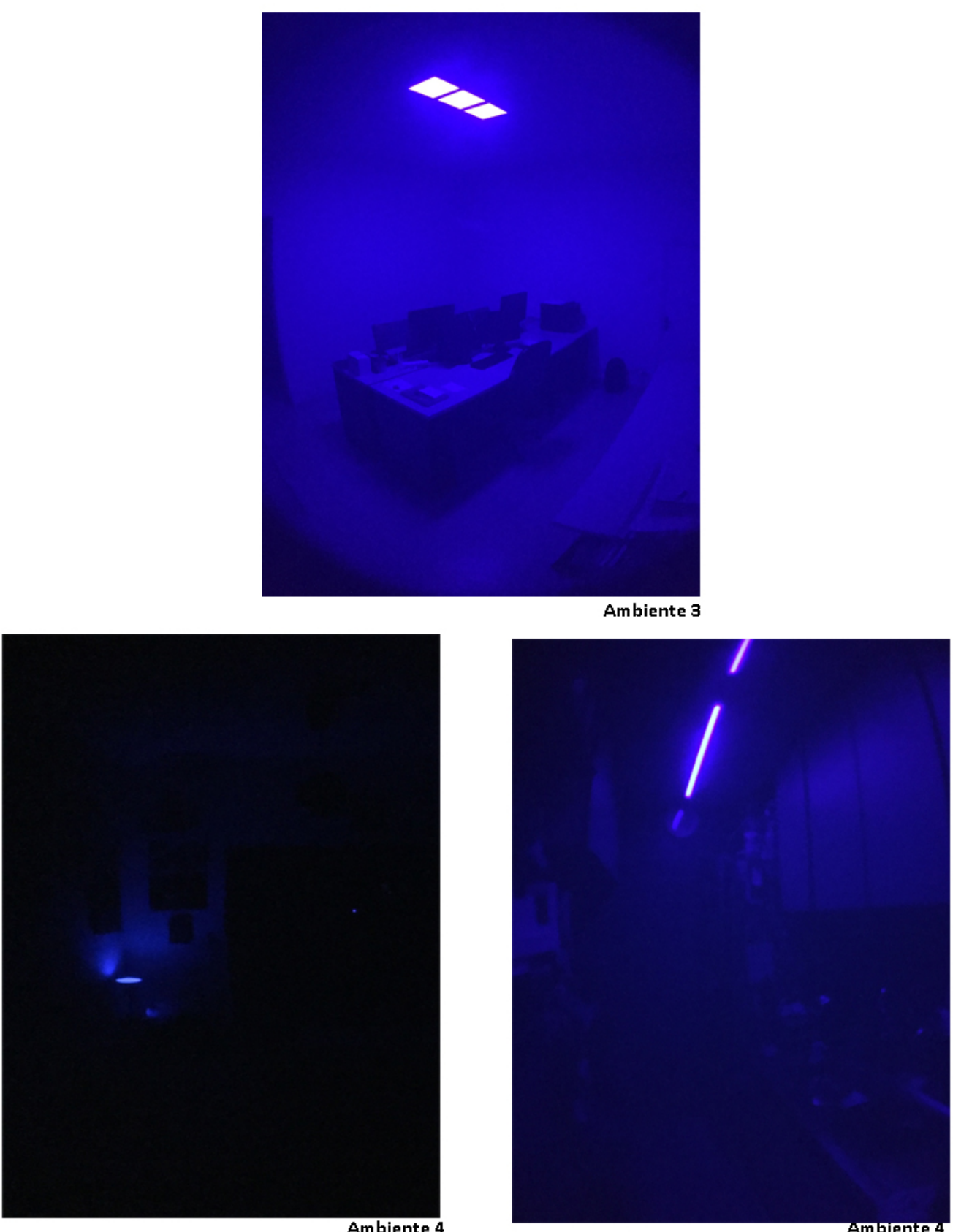

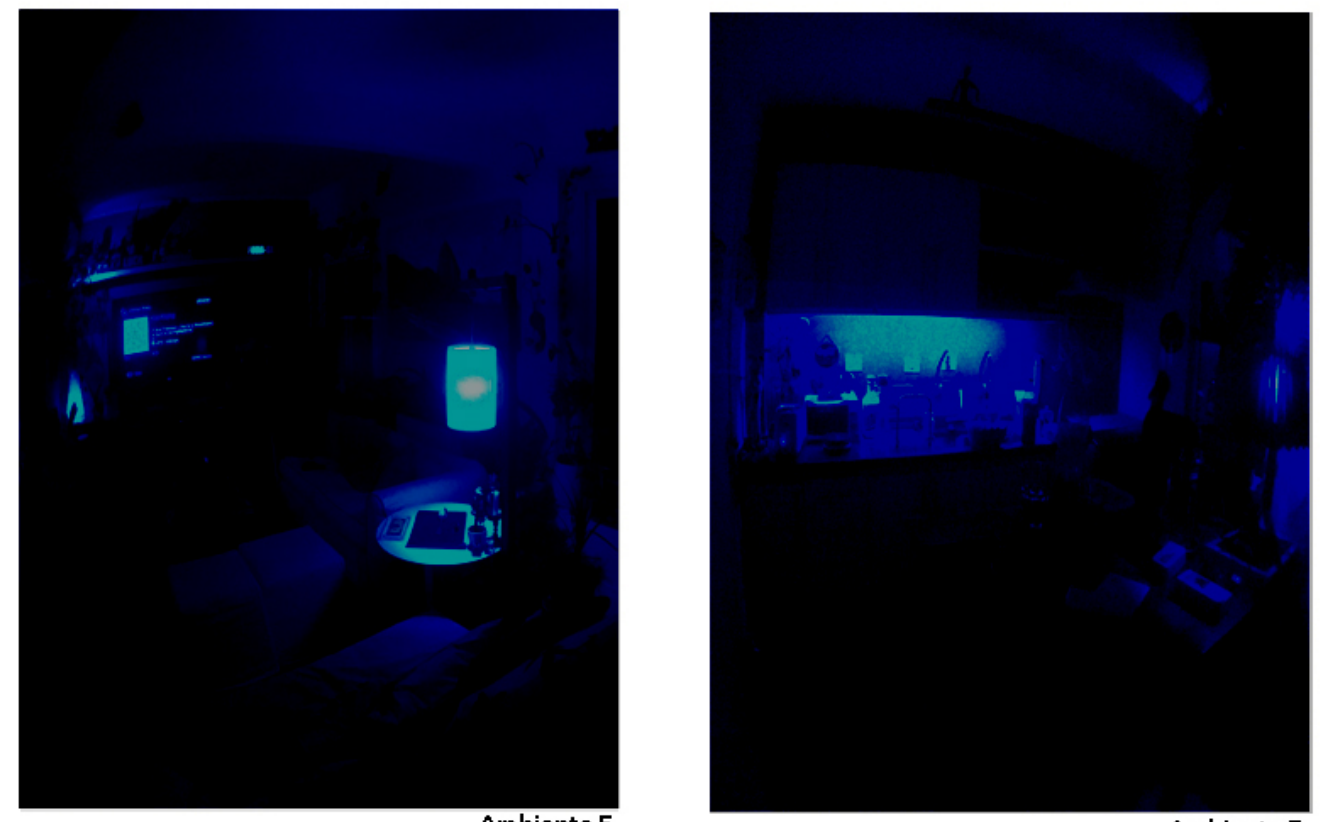

Ambiente 5

Ambiente 5
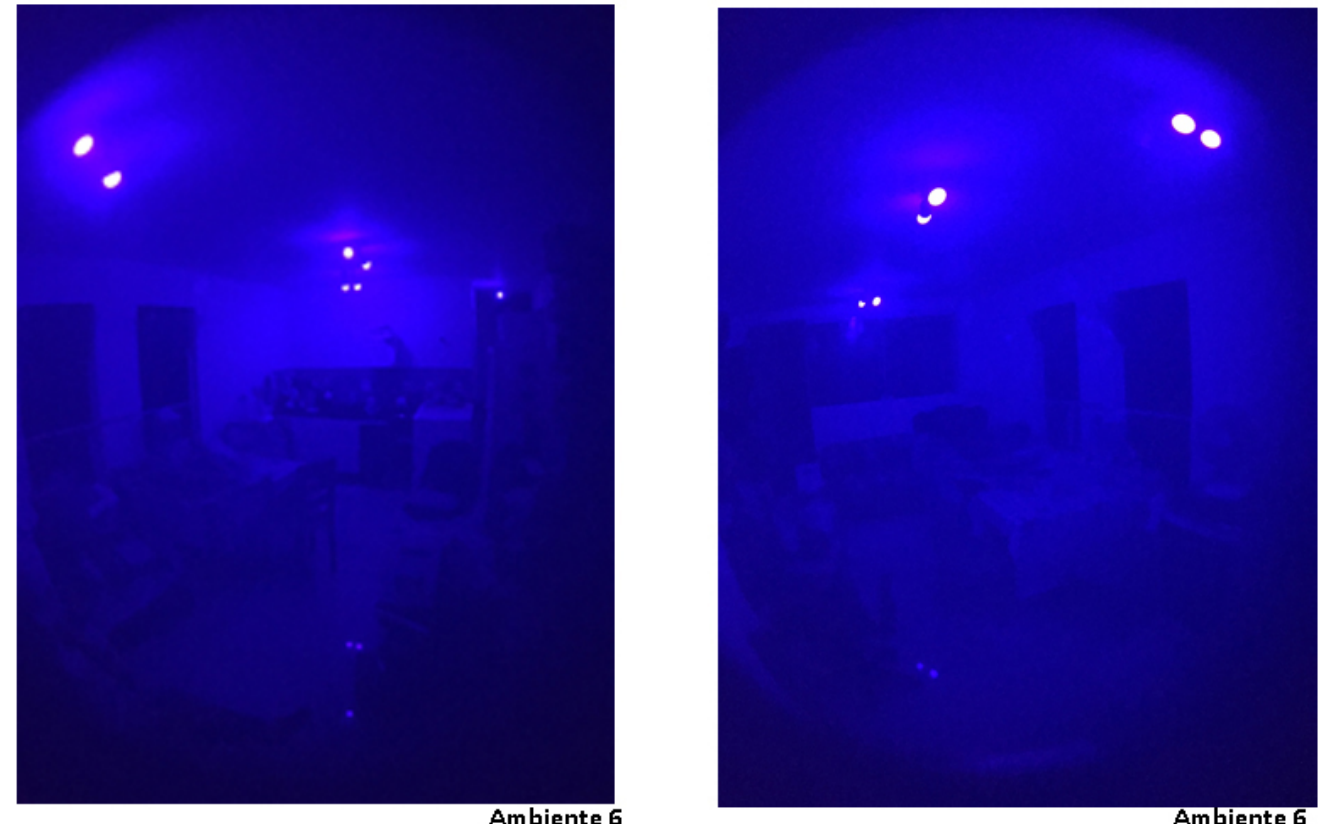

Ambiente 6 


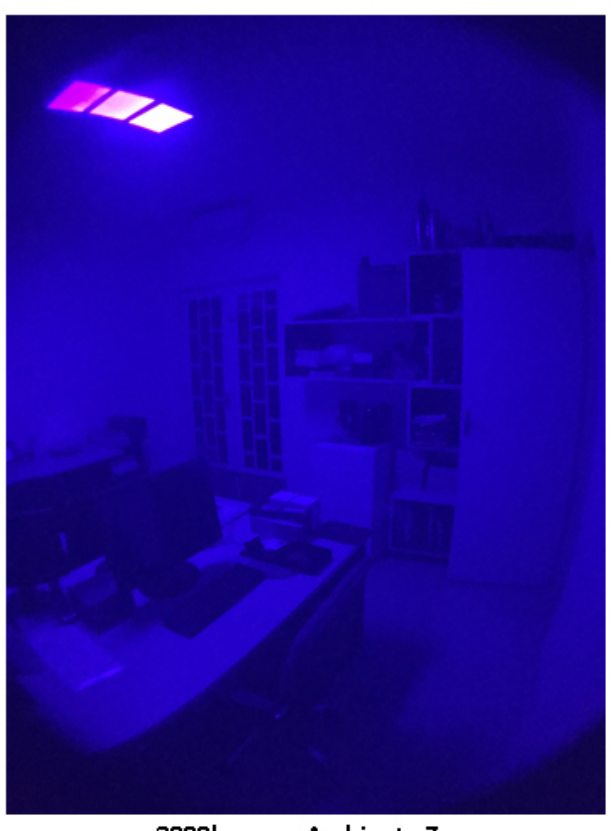

$3000 \mathrm{k}$

Ambiente 7 
Ambientes cujos usuários não apresentaram alteração hormonal em consequência da exposição noturna à luz de LEDs:
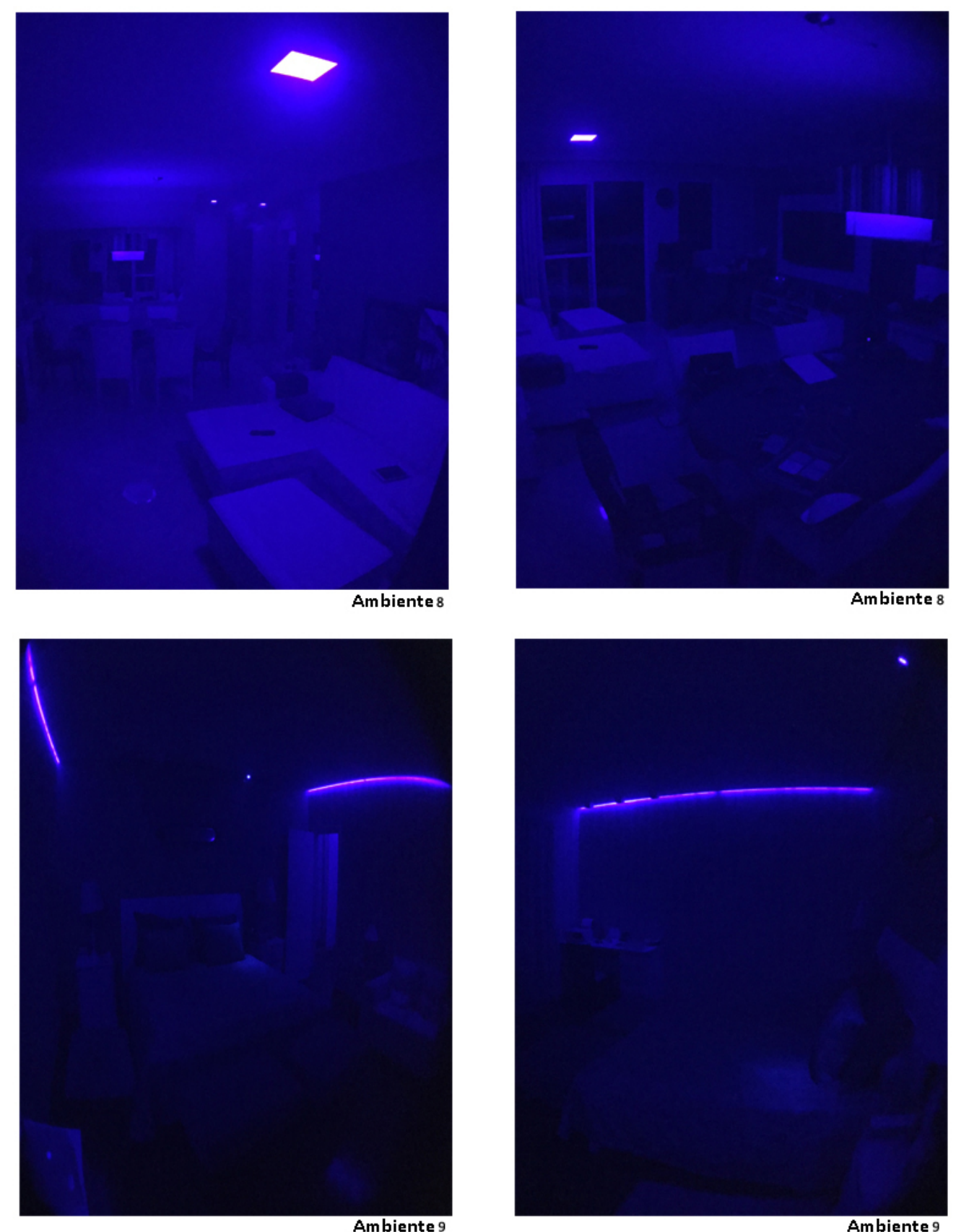

Ambiente 9 


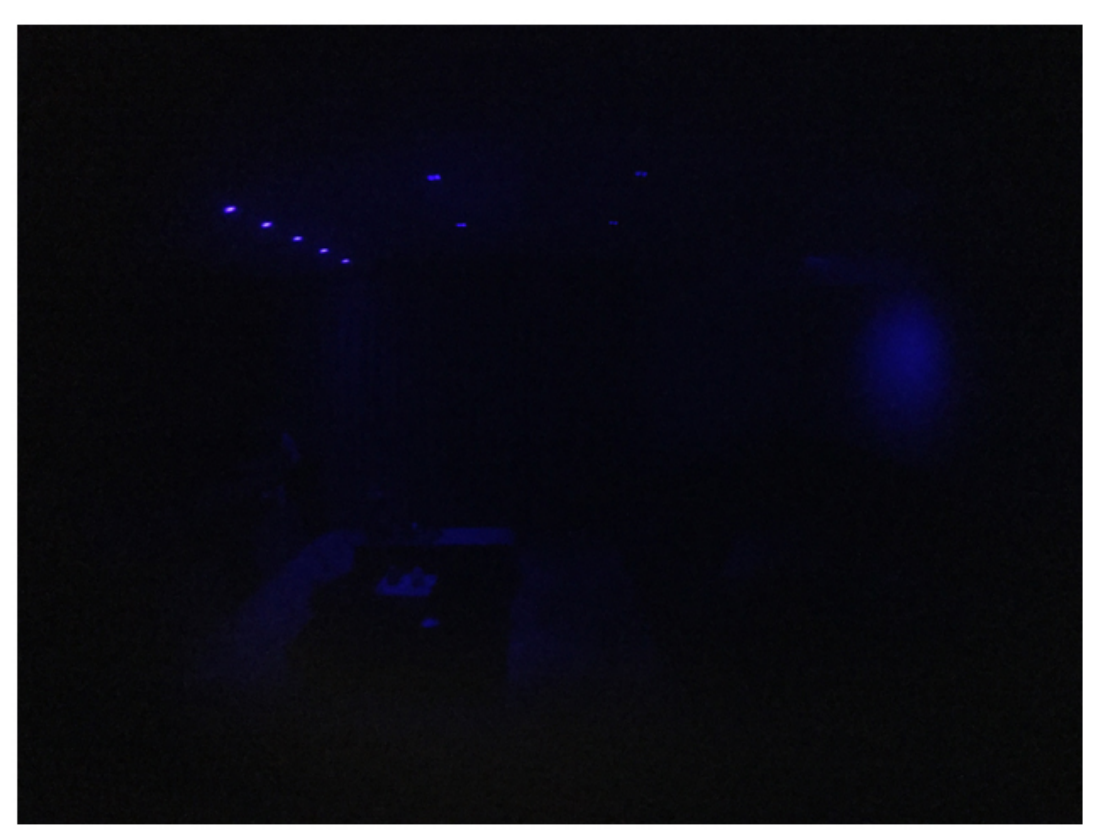

Ambiente 10 


\section{APÊNDICE F - Ficha de dados cadastrais}

Estudo: "Alterações não visuais e as diretrizes para o projeto luminotécnico residencial com LEDs"

Os questionários abaixo devem ser respondidos para este estudo.

Email address*

Nome Completo *

Endereço completo *

Cidade *

CEP *

Telefones * 
Data de Nascimento *

DD MM YrYY

/ I

Gênero *

Feminino

Masculino

Prefiro não dizer

Atividade profissional *

Horário de trabalho: *

Manhã (6h00 - 12h00)

Tarde (12h0o-18h0o)

Noite (18h00 - 24h00)

Madrugada (00h00 - 6h00)

Integral (8h00 - 18h00)

Irregular

Other:

\section{Você estuda? *}

( $\operatorname{Sim}$

Não 
Horário de Estudo: *

Manhã (6h00 - 12h00)

Tarde (12h00 - 18h00)

Noite $(18 \mathrm{~h} 00-24 \mathrm{~h} 00)$

Madrugada (00h00 - 6h00)

Integral (8h00 - 18h00

Irregular

Other:

\section{Grau de escolaridade: *}

Ensino Fundamental incompleto

Ensino Fundamental completo

Ensino Médio incompleto

Ensino Médio completo

Ensino Superior incompleto

Ensino Superior completo

Pós Graduação

Você toma algum tipo de medicamento regularmente? *

$\operatorname{sim}$

Não

Caso positivo, qual (is)? 
Você usa algum tipo de droga ilícita? *

( $\sin$

Não

Você fuma cigarros? *

Sim

Não

Você Toma café? *

Sim

Não

Caso positivo, quantos copinhos por dia?

Você faz atividade física? *

Sim

Não

Caso positivo, que tipo (s) de atividade (s)?

Caso positivo, com que frequência? 
Em qual estação do ano você se sente melhor? *

Verão

Inverno

Primavera

Outono

Indiferente

Você sente desconforto na entrada do horário de verão? *

Sim

Não

Se sim, quanto tempo dura este mal estar?

Uma semana

Um mês

Toda a duração do horário de verão

Autorizo a utilização dos dados deste questionários para fins exclusivamente acadêmicos. Entendo que minha identidade será mantida sob sigilo. *

Sim

Não 
Anexos 


\section{ANEXO A - Comitê de ética em pesquisa envolvendo seres humanos}

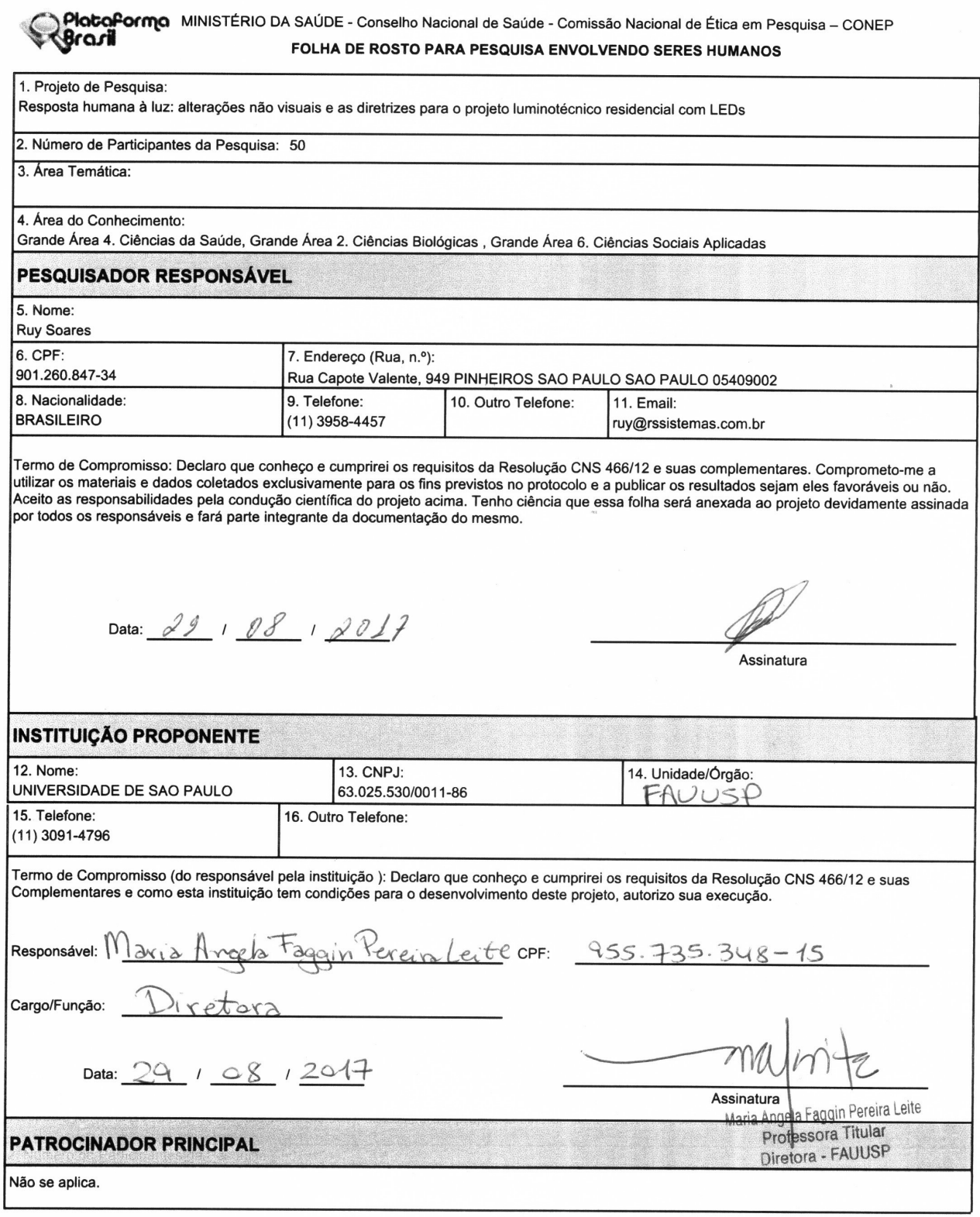


CARTA DE APRESENTAÇÃO DO PROTOCOLO DE PESQUISA AO COMITÊ DE ÉTICA EM PESQUISA ENVOLVENDO SERES HUMANOS DA ESCOLA DE ARTES, CIÊNCIAS E HUMANIDADES DA USP

Nível de Pesquisa:

Graduação ( ) -Pós-graduação (X) - Projeto Individual( ).

Tipo de Pesquisa:

RP ( ) - IC ( ) - TCC ( ) - lato sensu ( ) - Mestrado (X)

Doutorado ( ) - Projeto Individual ( ) - Outros ( )

Título do Projeto: Resposta Humana à Luz: alterações não visuais e as diretrizes para o projeto Iuminotécnico com LEDs

Pesquisador Executante: Ruy Barbosa Soares Filho

Pesquisador Responsável: Ruy Barbosa Soares Filho

Orientador: Prof. Leonardo Marques Monteiro

Instituição proponente: FAU-USP

Instituição co-participante (se houver): EACH-USP

IIma. Sra

Profa. Dra. Beatriz Aparecida Ozello Gutierrez

Coordenadora do Comitê de Ética em Pesquisa do

Envolvendo Seres Humanos da EACH - USP

Envio-Ihe o Projeto de Pesquisa acima mencionado, para apreciação deste Comitê.

Confirmo que todos os pesquisadores envolvidos nesta pesquisa realizaram a leitura e estão cientes do conteúdo da Resolução CNS n 466/12 e suas complementares e comprometo-me a:

apresentar documentação idêntica em todos os centros participantes do Estudo, caso a Pesquisa seja realizada em mais de um centro.

somente iniciar o Estudo após as devidas aprovações pelo CEP-EACH/USP e, se for o caso, pela Comissão Nacional de Ética em Pesquisa (CONEP/MS);

zelar pela privacidade e pelo sigilo das informações que serão obtidas e utilizadas para o desenvolvimento da Pesquisa;

utilizar os materiais e as informaçǒes obtidas no desenvolvimento deste Estudo apenas para atingir o objetivo proposto no mesmo e não utilizá-los para outros estudos, sem o devido consentimento dos sujeitos da pesquisa;

informar a este Comitê qualquer alteração que eventualmente venha a ocorrer no projeto;

- comunicar e justificar a este Comitê caso haja desistência ou cancelamento da Pesquisa;

- apresentar a este Comitê os relatórios parciais e final, de acordo com a Resolução CNS $n^{\circ}$ $466 / 12$ - item XI.2.d.

- tornar públicos os resultados do Estudo, quer sejam favoráveis ou não, respeitando a privacidade e os direitos individuais dos sujeitos da pesquisa.

São Paulo, 31 de agosto de 2017.

Pesquisador Responsável: Ruy Barbosa Soares Filho 


\section{PARECER CONSUBSTANCIADO DO CEP}

\section{DADOS DO PROJETO DE PESQUISA}

Título da Pesquisa: Resposta humana à luz: alterações não visuais e as diretrizes para o projeto luminotécnico residencial com LEDs

Pesquisador: Ruy Soares

Área Temática:

Versão: 2

CAAE: 74823717.0 .0000 .5390

Instituição Proponente: UNIVERSIDADE DE SAO PAULO

Patrocinador Principal: Financiamento Próprio

\section{DADOS DO PARECER}

Número do Parecer: 2.292 .761

Apresentação do Projeto:

Trata-se de projeto de pesquisa de mestrado, que visa estudar a relação entre os LEDs (Diodos Emissores de Luz) utilizados para iluminação arquitetônica residencial e os impactos não visuais causados nos usuários.

\section{Objetivo da Pesquisa:}

1) Averiguar o potencial circadiano noturno dos ambientes residenciais iluminados por LEDs;

2) Estabelecer parâmetros - que considerem o sistema não visual - para a utilização de LEDs nos projetos luminotécnicos residenciais

Avaliação dos Riscos e Benefícios:

Possiveis desconfortos deste estudo estão associados ao preenchimento de questionários, ao uso de equipamentos de coleta de dados no punho (com pequeno risco de provocar irritação na pele) e à coleta de urina noturna.

\section{Comentários e Considerações sobre a Pesquisa:}

Trata-se de pesquisa para averiguar os efeitos da iluminação por LEDs no ritmo biológico. A pesquisa será feita por meio de um grupo focal com pessoas expostas à iluminação residencial com LEDs no período noturno. Serão aplicados questionários para as seguintes avaliações: avaliação de transtorno psiquiátrico Self; avaliação da qualidade do sono; avaliação do ritmo

Endereço: Av. Arlindo Béttio, no 1000

Bairro: Ermelino Matarazzo

UF: SP Município: SAO PAULO

CEP: $03.828-000$

Telefone: (11)3091-1046

E-mail: cep-each@usp.br 


\section{USP - ESCOLA DE ARTES, CIÊNCIAS E HUMANIDADES DA UNIVERSIDADE DE SÃO}

Continuaçäo do Parecer: 2.292 .76

social. Além disso, será feita a identificação dos sistemas de iluminação utilizados nos ambientes de maior permanência à noite, bem como a coleta de imagens fotográcas HDR (High Dynamic Range) desses ambientes. Serão utilizados óculos bloqueadores de luz azul à noite durante os 3 primeiros dias do estudo. A coleta de dados será feita por meio de sensores: das oscilações de batimentos cardíacos, temperatura corporal, pressão arterial, actimetria e exposição à luz de cada ator do estudo de caso durante sete dias consecutivos. Para este estudo também será necessário verificar a produção do hormônio melatonina por meio de três coletas e urina noturna (12 horas) na primeira, quarta e sétima noite, em frascos a serem fornecidos pelo pesquisador.

\section{Considerações sobre os Termos de apresentação obrigatória:}

Os termos foram apresentados adequadamente, sendo que o autor apresenta o TCLE com os objetivos do estudo, direito ao anonimato e de desistência de fazer parte da pesquisa.

Recomend ações:

Sem recomendações

Conclusões ou Pendências e Lista de Inadequações:

Não há.

Considerações Finais a critério do CEP:

Este parecer foi elaborado baseado nos documentos abaixo relacionados:

\begin{tabular}{|c|c|c|c|c|}
\hline Tipo Documento & Arquivo & Postagem & Autor & Situação \\
\hline $\begin{array}{l}\text { Informações Básicas } \\
\text { do Projeto }\end{array}$ & $\begin{array}{l}\text { PB_INFORMAÇOEES_BÁSICAS_DO_P } \\
\text { ROJETO 934285.pdf }\end{array}$ & $\begin{array}{l}19 / 09 / 2017 \\
15: 12: 57\end{array}$ & & Aceito \\
\hline $\begin{array}{l}\text { TCLE / Termos de } \\
\text { Assentimento / } \\
\text { Justificativa de } \\
\text { Ausência } \\
\end{array}$ & TCLE_Rev1.pdf & $\begin{array}{c}19 / 09 / 2017 \\
15: 12: 22\end{array}$ & Ruy Soares & Aceito \\
\hline Folha de Rosto & FOLHA_DE_ROSTO.pdf & $\begin{array}{c}29 / 08 / 2017 \\
16: 32: 53 \\
\end{array}$ & Ruy Soares & Aceito \\
\hline $\begin{array}{l}\text { Projeto Detalhado / } \\
\text { Brochura } \\
\text { Investigador }\end{array}$ & Projeto_Atualizado_ago_2017.pdf & $\begin{array}{c}29 / 08 / 2017 \\
11: 21: 17\end{array}$ & Ruy Soares & Aceito \\
\hline
\end{tabular}

Situação do Parecer:

Aprovado

Necessita Apreciação da CONEP:

Não

Endereço: Av. Arlindo Béttio, $n^{\circ} 1000$

Bairro: Ermelino Matarazzo

UF: SP Município: SAO PAULO

CEP: $03.828-000$

Telefone: (11)3091-1046

E-mall: cep-each@usp.br 


USP - ESCOLA DE ARTES,
CIÊNCIAS E HUMANIDADES Plotoformo
DA UNIVERSIDADE DE SÃO

Continuaçäo do Parecer: 2.292 .761

SAO PAULO, 22 de Setembro de 2017

Assinado por:

Rosa Yuka Sato Chubaci

(Coordenador)

Endereço: Av. Arlindo Béttio, $n^{\circ} 1000$

Bairro: Ermelino Matarazzo

CEP: $03.828-000$

Município: SAO PAULO

Telefone: (11)3091-1046

E-mail: cep-each@usp.br 


\section{ANEXO B - Questionário de Cronotipo de Horne Östberg}

\section{Questionário para identificação de Cronotipo}

Você é matutino ou verpertino? Após responder a este questionário você saberá.

1) Considerando apenas seu bem-estar pessoal e com liberdade total de planejar seu dia, a que horas você se levantaria? *
$5 h 00-06 h 30$
$6 h 30-07 h 45$
$07 h 45-09 h 45$
$9 h 45-11 h 00$
$11 \mathrm{~h} 00-12 \mathrm{~h} 00$

2) Considerando apenas seu bem-estar pessoal e com liberdade total de planejar sua noite, a que horas você se deitaria? *
$20 h 00-21 h 00$
$21 h 00-22 h 15$
$22 \mathrm{~h} 15-24 \mathrm{~h} 30$
$24 h 30-01 h 45$
$01 h 45-03 h 00$

3) Até que ponto você depende do despertador para acordar de manhã? *

Nada Dependente

Não muito dependente

Razoavelmente dependente

Muito dependente 
4) Você acha fácil acordar de manhã? *

Nada fácil

Não muito fácil

Razoavelmente fácil

Muito fácil

5) Você se sente alerta durante a primeira meia hora depois de acordar?

Nada alerta

Não muito alerta

Razoavelmente alerta

Muito alerta

6) Como é seu apetite durante a primeira meia hora depois de acordar? *

Muito ruim

Não muito ruim

Razoavelmente bom

Muito bom

7) Durante a primeira meia hora depois de acordar você se sente cansado? *

Muito cansado

Não muito cansado

Razoavelmente em forma

Em plena forma 
8) Se você não tem compromisso no dia seguinte e comparando com sua hora habitual, a que horas você gostaria de ir deitar? *

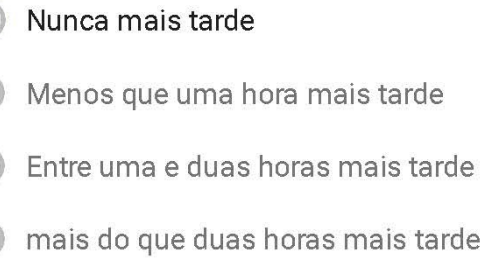

9) Você decidiu fazer exercícios físicos. Um amigo sugeriu o horário das 07 h00 às $08 \mathrm{~h} 00$ da manhã, duas vezes por semana. Considerando apenas ser bem-estar pessoal, o que você acha de fazer exercícios neste horário? *

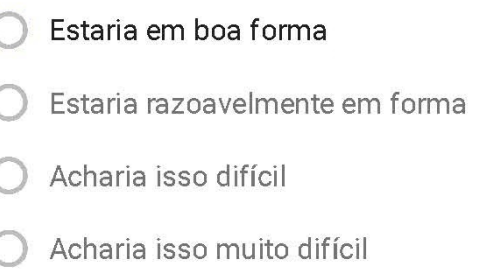

10) A que horas da noite você se sente cansado e com vontade de dormir? *
$20 h 00-21 h 00$
$21 h 00-22 h 15$
22h15-00h45
$00 h 45-02 h 00$
$02 h 00-03 h 00$ 
11) Você quer estar no máximo de sua forma para fazer um teste que dura duas horas e que você sabe que é mentalmente cansativo.

Considerando apenas o seu bem-estar pessoal, qual desses horários você escolheria para fazer esse teste? *

Das 08 h00 às 10 h00

Das 11 h00 às 13 h00

Das 15 h0o às $17 h 00$

Das 19 h00 às 21 h00

12) Se você fosse deitar às $23 h 00$, em que nível de cansaço você se sentiria? *

Nada cansado

Um pouco cansado

Razoavelmente cansado

Muito cansado

13) Por alguma razão você foi dormir várias horas mais tarde do que é seu costume. Se no dia seguinte você não tiver hora certa para acordar, o que aconteceria com você? *

Acordaria na hora normal, sem sono

Acordaria na hora normal, com sono

Acordaria na hora normal e dormiria novamente

Acordaria mais tarde do que de costume 
14) Se você tiver que ficar acordado das 04 h00 às $06 h 00$ horas para realizar uma tarefa (Ex: um plantão e não tiver compromissos no dia seguinte, o que você faria? *
Só dormiria depois de fazer a tarefa
Tiraria uma soneca antes da tarefa e dormiria depois
Dormiria bastante antes e tiraria uma soneca depois
Só dormiria antes de fazer a tarefa

15) Se você tiver que fazer duas horas de exercício físico pesado e considerando apenas o seu bem-estar pessoal, qual destes horários você escolheria? *
das 08 h00 às 10 h00 horas
das 11 h00 às 13 hoo horas
das 15 h00 às $17 h 00$ horas
das 19 hoo às 21 hoo horas

16) Você decidiu fazer exercícios físicos. Um amigo sugeriu o horário das $22 \mathrm{~h} 00$ às $23 \mathrm{~h} 00$ horas, duas vezes por semana. Considerando apenas o seu bem-estar pessoal, o que você acha de fazer exercícios neste horário? *
Estaria em boa forma
Estaria razoavelmente em forma
Acharia isso difícil
Acharia isso muito difícil 
17) Suponha que você possa escollher o seu próprio horário de trabalho e que você deva trabalhar cinco horas seguidas por dia. Imagine que seja um serviço interessante e que você ganhe por produção. Qual o horário que você escolheria? (marque a hora do início) *

$10 h 00$

18) A que hora do dia você atinge seu melhor momento de bem-estar? *

$05 h 00-08 h 00$

$08 h 00-10 h 00$

$10 h 00-17 h 00$

$17 h 00-22 h 00$

$22 h 00-05 h 00$

19) Fala-se em pessoas matutinas e vespertinas (as primeiras gostam de acordar cedo e dormir cedo, as segundas de acordar tarde e dormir tarde) Com qual desses tipos você se identifica? *

Tipo matutino

Mais matutino que vespertino

Mais vespertino que matutino

Tipo vespertino 


\section{ANEXO C - Self Reporting Questionnaire - SRQ-20}

SQR20 - Estas questões são relacionadas a certas dores e problemas que podem ter lhe incomodado nos últimos 30 dias. Se você acha que a questão se aplica a você e você teve o problema descrito nos últimos 30

diasresponda SIM. Por outro lado, se a questão não se aplica a você e você não teve o problema nos últimos $30 d i a s$, responda NÃO.

1) Você tem dores de cabeça freqüente?*

$\operatorname{sim}$

Não

2) Tem falta de apetite? *

$\operatorname{sim}$

Não

3) Dorme mal? *

sim

Não

4) Assusta-se com facilidade? *

$\operatorname{sim}$

Não

5) Tem tremores nas mãos? *

$\operatorname{sim}$

Não

6) Sente-se nervoso (a), tenso (a) ou preocupado (a)? *

$\operatorname{sim}$

Não

7) Tem má digestão? *

$\operatorname{sim}$

Não 
8) Tem dificuldades de pensar com clareza? *

Sim

Não

9) Tem se sentido triste ultimamente?*

Sim

Não

10) Tem chorado mais do que costume?*

Sim

Não

11) Encontra dificuldades para realizar com satisfação suas atividades diárias? *

( $\operatorname{sim}$

Não

12) Tem dificuldades para tomar decisões? *

Sim

Não

13) Tem dificuldades no serviço (seu trabalho é penoso, Ihe causa sofrimento?) *

Sim

Não 
14) É incapaz de desempenhar um papel útil em sua vida? *

( $\sin$

Não

15) Tem perdido o interesse pelas coisas? *

$\operatorname{sim}$

Não

16) Você se sente uma pessoa inútil, sem préstimo? *

Sim

Não

17) O pensamento de acabar com a vida já passou por sua cabeça? *

Sim

1 Não

18) Sente-se cansado (a) o tempo todo? *

- $\operatorname{Sim}$

( Não

19) Você se cansa com facilidade?*

Sim

- Não

20) Têm sensações desagradáveis no estomago? *

Sim

Não 


\section{ANEXO D - Pittsburg Sleep Quality Index - PSQI}

Questionário de Qualidade do sono (PSQI). As seguintes questões são relacionadas ao seu hábito de sono no ÚLTIMO MÊS. Suas respostas devem indicar o mais fielmente o que ocorreu na maioria dos dias e noites dos útimos 30 dias.

1) Durante o último mês, você foi deitar a que horas? *

Time

2) Durante o último mês, a que horas pegou no sono? * Time :

3) Durante o último mês, a que horas você acordou? *

$$
\text { Time }
$$

4) Durante o último mês, quantas horas de sono você teve por noite? (diferenciar de quanto tempo ficou deitado) * 
5a) Durante o último mês, quantas vezes você teve problemas com seu sono porque não conseguiu pegar no sono durante 30 minutos? *

Nenhum episódio no ultimo mês

Menos do que 1 vez na semana

1 ou 2 vezes na semana

3 ou 4 vezes na semana

5b) Durante o último mês, quantas vezes você teve problemas com seu sono porque acordou no meio da noite ou muito cedo pela manhã? *

Nenhum episódio no ultimo mês

Menos do que 1 vez na semana

1 ou 2 vezes na semana

3 ou 4 vezes na semana

5c) Durante o último mês, quantas vezes você teve problemas com seu sono porque teve de ir ao banheiro? *

Nenhum episódio no ultimo mês

Menos do que 1 vez na semana

1 ou 2 vezes na semana

3 ou 4 vezes na semana

5d) Durante o último mês, quantas vezes você teve problemas com seu sono porque não conseguiu respirar direito? *

Nenhum episódio no ultimo mês

Menos do que 1 vez na semana

1 ou 2 vezes na semana

3 ou 4 vezes na semana 
5e) Durante o último mês, quantas vezes você teve problemas com seu sono porque apresentou tosse ou ronco alto? *

Nenhum episódio no ultimo mês

Menos do que 1 vez na semana

1 ou 2 vezes na semana

3 ou 4 vezes na semana

5f) Durante o último mês, quantas vezes você teve problemas com seu sono porque sentiu muito frio? *

Nenhum episódio no ultimo mês

Menos do que 1 vez na semana

1 ou 2 vezes na semana

3 ou 4 vezes na semana

$5 \mathrm{~g}$ ) Durante o último mês, quantas vezes você teve problemas com seu sono porque sentiu muito calor? *

Nenhum episódio no ultimo mês

Menos do que 1 vez na semana

1 ou 2 vezes na semana

3 ou 4 vezes na semana

5h) Durante o último mês, quantas vezes você teve problemas com seu sono porque teve pesadelos? *

Nenhum episódio no ultimo mês

Menos do que 1 vez na semana

1 ou 2 vezes na semana

3 ou 4 vezes na semana 
5i) Durante o último mês, quantas vezes você teve problemas com seu sono porque sentiu dor? *

Nenhum episódio no ultimo mês

Menos do que 1 vez na semana

1 ou 2 vezes na semana

3 ou 4 vezes na semana

5j) Durante o último mês, quantas vezes você teve problemas com seu sono por outras razões? (descreva abaixo) *

Nenhum episódio no ultimo mês

Menos do que 1 vez na semana

1 ou 2 vezes na semana

3 ou 4 vezes na semana

6) Durante o último mês, como você classificaria a qualidade do seu sono? *

Muito boa

Boa

Ruim

Muito ruim

7) Durante o último mês, quantas vezes você tomou remédio, chá ou (descreva abaixo) devido a problemas com o sono? *

Nenhum episódio no ultimo mês

Menos do que 1 vez na semana

1 ou 2 vezes na semana

3 ou 4 vezes na semana 
8) Durante o último mês, quanta vezes você teve problema para ficar acordado enquanto dirigia, comia ou estava envolvido com atividades sociais? *

Nenhum episódio no ultimo mês

Menos do que 1 vez na semana

1 ou 2 vezes na semana

3 ou 4 vezes na semana

9) Durante o último mês, quanto o seu problema de sono atrapalhou, diminuindo seu entusiasmo para fazer coisas? *

Não tem sido um grande problema

Às vezes, tem sido um problema pequeno

Na maioria das vezes tem sido um problema

Tem sido um grande problema 


\section{ANEXO E - Escala de Sonolência de Epworth}

Escala de Sonolência de Epworth

Qual a probabilidade de você cochilar ou adormecer nas seguintes situações, em contraste com apenas sentindo cansado? As questões referem-se ao seu modo de vida habitual nos últimos tempos. Mesmo que você não tenha feito algumas destas coisas recentemente tente definir a forma como elas teriam afetado você.

Sentado e lendo: *

Nenhuma chance de cochilar

Pequena chance de cochilar

Moderada chance de cochilar

Alta chance de cochilar

Vendo TV: *

Nenhuma chance de cochilar

Pequena chance de cochilar

Moderada chance de cochilar

Alta chance de cochilar

Sentado em lugar público (ex. sala de espera, igreja): *

Nenhuma chance de cochilar

Pequena chance de cochilar

Moderada chance de cochilar

Alta chance de cochilar

Como passageiro de trem, carro ou ônibus andando uma hora sem parar:

*

Nenhuma chance de cochilar

Pequena chance de cochilar

Moderada chance de cochilar

Alta chance de cochilar 
Deitando-se para descansar à tarde, quando as circunstâncias permitem: *

Nenhuma chance de cochilar

Pequena chance de cochilar

Moderada chance de cochilar

Alta chance de cochilar

Sentado e conversando com alguém: *

Nenhuma chance de cochilar

Pequena chance de cochilar

Moderada chance de cochilar

Alta chance de cochilar

Sentado calmamente após almoço sem álcool: *

Nenhuma chance de cochilar

Pequena chance de cochilar

Moderada chance de cochilar

Alta chance de cochilar

Se você tiver carro, enquanto para por alguns minutos quando pega trânsito intenso: *

Nenhuma chance de cochilar

Pequena chance de cochilar

Moderada chance de cochilar

Alta chance de cochilar 